\title{
Site U1373'
}

\author{
Expedition 330 Scientists $^{2}$
}

\section{Chapter contents}

Background and objectives........... 1

Operations.......................

Sedimentology .................

Paleontology ................ 8

Igneous petrology and volcanology .......9

Alteration petrology ............ 12

Structural geology............. 14

Geochemistry ................ 15

Physical properties ............. 17

Paleomagnetism ............... 20

Microbiology ...................22

References..................23

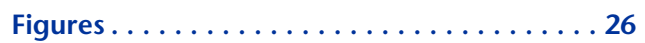

Tables......................... 92

${ }^{1}$ Expedition 330 Scientists, 2012. Site U1373. In Koppers, A.A.P., Yamazaki, T., Geldmacher, J., and the Expedition 330 Scientists, Proc. IODP, 330: Tokyo (Integrated Ocean Drilling Program Management International, Inc.).

doi:10.2204/iodp.proc.330.104.2012

'Expedition 330 Scientists' addresses.

\section{Background and objectives}

Site U1373 (alternate prospectus Site LOUI-6A) on Rigil Guyot $\left(28.6^{\circ} \mathrm{S}\right.$ Guyot) was the second site completed during Integrated Ocean Drilling Program (IODP) Expedition 330 (Fig. F1) and the first of two sites drilled on Rigil Guyot (Sites U1373 and U1374), the second of five seamounts drilled in the Louisville Seamount Trail. At an inferred age of $\sim 73 \mathrm{Ma}$, Site U1373 is one of the older seamount targets and is only a few million years younger than Site U1372 on Canopus Guyot to the northwest. If the Louisville hotspot experienced a paleolatitude shift similar to the recorded $\sim 15^{\circ}$ southern motion of the Hawaiian hotspot during the Late Cretaceous, this shift is expected to be largest for the oldest seamounts in the Louisville Seamount Trail. Rigil Guyot was determined to be a good target because it shows no evidence of tilting or significant posterosional volcanism. Because Rigil Guyot is only slightly younger than Canopus Guyot, a paleolatitude shift of Site U1373 is expected to be similar to that of Site U1372 and will strengthen our determinations of the Louisville paleolatitude at the old end of the trail. This volcanic edifice is part of a small cluster of two guyots (oriented east-west at $28.6^{\circ} \mathrm{S}$ and $28.7^{\circ} \mathrm{S}$ ) and one small seamount to the south $\left(28.8^{\circ} \mathrm{S}\right)$ (Fig. F2). Rigil Guyot itself consists of a single volcanic center that is $40 \mathrm{~km}$ long and 36 $\mathrm{km}$ wide; however, two small (perhaps posterosional) pedestals remain on the western portion of its summit. Site U1373 was placed on the summit plain close to the northern shelf edge at $1447 \mathrm{~m}$ water depth (Fig. F2). Side-scan sonar reflectivity and $3.5 \mathrm{kHz}$ subbottom profiling data indicate that Site U1373 is covered with $<10 \mathrm{~m}$ of pelagic sediment, and seismic reflection profiles (Koppers et al., 2010) show that this site is characterized by a $110 \mathrm{~m}$ thick section of reflectors (volcaniclastics?) dipping toward the south and overlaying igneous basement.

Site U1373 on Rigil Guyot was an alternate site selected because operations for Site U1372 on Canopus Guyot were cut short (see "Operations" in the "Site U1372" chapter [Expedition 330 Scientists, 2012b]). To increase our prospects for determining the most precise paleolatitude on the old end of the Louisville Seamount Trail, we resorted to alternate Site LOUI-6A on Rigil Guyot, which formed likely only $3 \mathrm{~m} . \mathrm{y}$. after Canopus Guyot.

The original drilling plan was to recover soft sediment using a gravity-push approach with little or no rotation of the rotary core barrel assembly, followed by standard coring into the volcaniclas- 
tic material and $350 \mathrm{~m}$ into igneous basement. A full downhole logging series was planned, including the standard triple combination and Formation MicroScanner-sonic tool strings, the Ultrasonic Borehole Imager tool, and the third-party Göttingen Borehole Magnetometer tool. However, upon tagging the seafloor before starting Hole U1373A, a vibration-isolated television (VIT) camera survey clearly showed cobble fields covered by a patchy sediment blanket. A better spot with more sediment cover was selected using the VIT camera, but it became clear upon spudding the hole that a hard-ground entry had to be made. As a result, little to no soft pelagic sediment was recovered, and coring went straight into consolidated volcaniclastics. Basaltic basement was encountered at 33.9 meters below seafloor (mbsf). Because reentry using a free-fall funnel failed, Hole U1373A had to be abandoned at only 65.7 mbsf. No downhole logging could be carried out.

\section{Objectives}

Drilling during Ocean Drilling Program (ODP) Leg 197 provided compelling evidence for the motion of mantle plumes by documenting a large $\sim 15^{\circ}$ shift in paleolatitude for the Hawaiian hotspot (Tarduno et al., 2003; Duncan et al., 2006). This evidence led to testing two geodynamic end-member models during Expedition 330, namely that the Louisville and Hawaiian hotspots moved coherently over geological time (Wessel and Kroenke 1997; Courtillot et al. 2003) or, quite the opposite, that these hotspots show considerable interhotspot motion, as predicted by mantle flow models (Steinberger, 2002; Steinberger et al., 2004; Koppers et al., 2004; Steinberger and Antretter, 2006; Steinberger and Calderwood, 2006). The most important objective of Expedition 330 , therefore, was to core deep into the igneous basement of four seamounts in the Louisville Seamount Trail in order to sample a large number of in situ lava flows ranging in age between 80 and $50 \mathrm{Ma}$. A sufficiently large number of these independent cooling units would allow high-quality estimates of paleolatitude to be determined, and any recorded paleolatitude shift (or lack thereof) could be compared with seamounts in the Hawaiian-Emperor Seamount Trail. For this reason, Expedition 330 mimicked the drilling strategy of Leg 197 by drilling seamounts equivalent in age to Detroit (76-81 Ma), Suiko (61 Ma), Nintoku (56 Ma), and Koko (49 Ma) Seamounts in the Emperor Seamount Trail. Accurate paleomagnetic inclination data are required for the drilled seamounts in order to establish a record of past Louisville hotspot motion, and, together with high-resolution ${ }^{40} \mathrm{Ar} /{ }^{39} \mathrm{Ar}$ age dating of the cored lava flows, these data will help us constrain the paleolatitudes of the Louisville hotspot between 80 and 50 Ma. These comparisons are of fundamental importance in determining whether these two primary hotspots have moved coherently or not and in understanding the nature of hotspots and convection in the Earth's mantle.

Expedition 330 also aimed to provide important insights into the magmatic evolution and melting processes that produced and constructed Louisville volcanoes as they progressed from shield to postshield, and perhaps posterosional, volcanic stages. Existing data from dredged lava suggest that the mantle source of the Louisville hotspot has been remarkably homogeneous for as long as 80 m.y. (Cheng et al., 1987; Hawkins et al., 1987; Vanderkluysen et al., 2007; Beier et al., 2011). In addition, all dredged basalt is predominantly alkalic and possibly represents a mostly alkalic shield-building stage, in contrast to the tholeiitic shield-building stage of volcanoes in the Hawaiian-Emperor Seamount Trail (Hawkins et al., 1987; Vanderkluysen et al., 2007; Beier et al., 2011). Therefore, the successions of lava flows cored during Expedition 330 will help us characterize the Louisville Seamount Trail as the product of a primary hotspot and test the long-lived homogeneous geochemical character of its mantle source. Analyses of melt inclusions, volcanic glass samples, high-Mg olivine, and clinopyroxene phenocrysts will provide further constraints on the asserted homogeneity of the Louisville plume source, its compositional evolution between 80 and $50 \mathrm{Ma}$, its potential mantle plume temperatures, and its magma genesis, volatile outgassing, and differentiation. Incremental heating ${ }^{40} \mathrm{Ar} /{ }^{39} \mathrm{Ar}$ age dating will allow us to establish age histories within each drill core, delineating any transitions from the shield-building phase to the postshield capping and posterosional stages.

Another important objective of Expedition 330 at Site U1373 was to use new paleolatitude estimates, ${ }^{40} \mathrm{Ar} /{ }^{39} \mathrm{Ar}$ ages, and geochemical data to decide whether the oldest seamounts in the Louisville Seamount Trail were formed close to the $18^{\circ}-28^{\circ} \mathrm{S}$ paleolatitude determined from ODP Leg 192 basalt for the Ontong Java Plateau (Riisager et al., 2003) and whether this large igneous province was genetically linked to the Louisville hotspot or not. Such a determination would prove or disprove the hypothesis that the Ontong Java Plateau formed from massive large igneous province volcanism at $120 \mathrm{Ma}$, when the preceding plume head of the Louisville mantle upwelling reached the base of the Pacific lithosphere and started extensive partial melting (e.g., Richards and Griffiths, 1989; Mahoney and Spencer, 1991). 
Finally, basalt and sediment cored at Site U1373 were planned for use in a range of secondary objectives, such as searching for active microbial life in the old seamount basement and determining whether fossil traces of microbes were left behind in volcanic glass or rock biofilms. We also planned to determine ${ }^{3} \mathrm{He} /$ ${ }^{4} \mathrm{He}$ and ${ }^{186} \mathrm{Os} /{ }^{187} \mathrm{Os}$ signatures of the Louisville mantle plume to evaluate its potential deep-mantle origin, to use oxygen and strontium isotope measurements on carbonates and zeolites in order to assess the magnitude of carbonate vein formation in aging seamounts and its role as a global $\mathrm{CO}_{2}$ sink, to agedate celadonite alteration minerals for estimating the total duration of low-temperature alteration following seamount emplacement, and to determine the hydrogeological and seismological character of the seamount basement.

\section{Operations}

The vessel arrived at Site U1373 on Rigil Guyot at $1730 \mathrm{~h}$ on 31 December 2010 after a $146 \mathrm{nmi}$ voyage from Site U1372 that was accomplished at an average speed of $10.1 \mathrm{kt}$ (all times are New Zealand Daylight Time, Universal Time Coordinated [UTC] + $13 \mathrm{~h}$ ). A new bottom-hole assembly with a Type C-4 rotary core barrel bit and a mechanical bit release was made up and deployed. The corrected precision depth recorder depth for this site was 1455 meters below rig floor (mbrf). The vibration-isolated television (VIT) frame was deployed with the drill string, and by $0200 \mathrm{~h}$ on 1 January 2011 a seafloor strewn with large boulders and outcrops of hard rock was displayed on the monitor. From 0230 to $0445 \mathrm{~h}$ a VIT survey was made around the periphery of the site until a clear area was found that appeared to be able to support a free-fall funnel (FFF) deployment. After the driller tagged the seafloor at $1458.0 \mathrm{mbrf}$ (1447.0 meters below sea level [mbsl]), the top drive was picked up and Hole U1373A was spudded at $0700 \mathrm{~h}$ on 1 January (Fig. F3).

The hole was routinely advanced to $65.7 \mathrm{mbsf}$, by which point the bit had accumulated 69.7 rotating hours and required replacement (Table T1). Basaltic basement was encountered at 33.9 mbsf. When the bit was replaced, penetration into basement was $31.8 \mathrm{~m}$, with an average penetration rate of $0.9 \mathrm{~m} / \mathrm{h}$. The strategy of pulling half-cores helped to increase the average basement recovery to $91 \%$. Average recovery for the entire hole at this point was $72 \%$. The hole was flushed with $20 \mathrm{bbl}$ mud sweeps prior to recovering each core to keep the hole clean of cuttings. An additional $40 \mathrm{bbl}$ mud sweep was circulated before initiating the bit trip.
A FFF was made up and deployed at $1845 \mathrm{~h}$ on 4 January. The VIT frame was launched and the FFF was monitored as the bit was withdrawn from the hole. The bit cleared the lip of the funnel at $2005 \mathrm{~h}$ and was on deck by $1210 \mathrm{~h}$ on 5 January. The used bit was found to be in excellent condition (slight cone wear, no missing inserts, and tight bearings) and was $1 / 8$ inch undergauge in spite of having accumulated 70 rotating hours. A new bit was made up to the bottom-hole assembly and deployed along with an additional stand of drill collars.

From 0630 to $0845 \mathrm{~h}$ the driller attempted a reentry into the FFF, but the bit appeared to bind about $1 \mathrm{ft}$ into the throat of the funnel and could not be advanced any farther. The mud pump flow was increased on the chance that any obstruction would be hydraulically dislodged, but the end result was that the FFF tipped over on its side. It was surmised that the $2.7 \mathrm{~m}$ FFF casing was not lodged firmly in the hole when the old bit was withdrawn and that the only element that was holding the FFF vertical was the pile of cuttings.

Although the open hole was not visible on the camera, the driller attempted a blind stab into the hole by lowering the bit into the sediment cover around the periphery of the FFF. This course of action was terminated after $2.25 \mathrm{~h}$, and the decision was made to offset the ship to a recently approved alternate site (prospectus Site LOUI-6B) located on the other side of the seamount's summit. After the drill string was picked up to 1111 mbrf, the vessel was offset in dynamic positioning mode to Site U1374 in the afternoon hours of 5 January.

\section{Sedimentology}

The following stratigraphic units were defined at Site U1373 on the basis of distinct sedimentary facies, sediment compositions, and cementation patterns observed at macroscopic and microscopic scales (Fig. F4):

- Unit I (0-3.05 mbsf; lower boundary = Section 330-U1373A-1R-3, $37 \mathrm{~cm}$ ): sedimentary interval composed of grain-supported multicolor bioclast basalt conglomerate and matrix-supported multicolor basalt conglomerate with bioclasts. Unit I was divided into three subunits (see below).

- Unit II (9.60-15.70 mbsf; lower boundary = Section 330-U1373A-3R-2, $64 \mathrm{~cm}$ ): mainly volcanic interval composed of three basalt lava flows with two interbeds of grain-supported multicolor basalt breccia devoid of bioclasts.

- Unit III (15.70-33.90 mbsf; lower boundary = Section 330-U1373A-7R-1, $120 \mathrm{~cm}$ ): sedimentary 
interval composed of grain-supported multicolor basalt bioclast conglomerate and matrix-supported dark multicolor basalt breccia devoid of bioclasts. Unit III was divided into four subunits (see below).

\section{Unit I}

Interval: Sections 330-U1373A-1R-1, $0 \mathrm{~cm}$, to 1R-3, $37 \mathrm{~cm}$

Depth: 0-3.05 mbsf

Age: Late Cretaceous or younger

Stratigraphic Unit I is composed of basalt conglomerate or breccia that extends downhole from the seafloor to a volcanic interval with basalt lava flows in underlying Unit II at 3.05 mbsf (Fig. F4). Unit I was divided into three subunits on the basis of (1) distinct sedimentary textures and abundances of micrite, cement, and bioclasts and (2) the occurrence of an erosional contact between basalt conglomerate (above) and bioclast basalt conglomerate (below) at 2.66 mbsf (Section 330-U1373A-1R-3, $37 \mathrm{~cm}$ ). The exact thicknesses of Subunits IA, IB, and IC are unknown because of poor recovery in Core 330U1373A-1R ( 30\% recovery). Also, the relationship between Units I and II and Subunits IA and IB is ambiguous because interunit contacts were not recovered. As a consequence, the interval between 3.05 and 9.60 mbsf remains unconstrained in our lithostratigraphic interpretation. At Site U1373, paleontological data did not allow definition of a precise age of sediment deposition (see "Paleontology"). A Late Cretaceous or younger age was inferred for Unit I from paleontological data in Unit III (see "Paleontology") and stratigraphic relationships with underlying units. The largest basalt clasts (as measured over $10 \mathrm{~cm}$ intervals) are similar in size throughout Unit I and range between pebble and cobble size (Fig. F4). Macroscopic and microscopic observations allowed recognition of 12 types of basalt clasts in Units I and III (see U1373A.DOC in CHAR in SEDIMENT in "Supplementary material"). The nature and occurrence of these clasts are summarized in Table T2. Unit I has a clast population compositionally similar to that of Subunits IIIA-IIIC.

\section{Subunit IA}

Interval: Sections 330-U1373A-1R-1, $0 \mathrm{~cm}$, to 1R-1, $15 \mathrm{~cm}$

Depth: 0-0.15 mbsf

Age: Late Cretaceous or younger

Stratigraphic Subunit IA extends from the seafloor to 0.15 mbsf (Fig. F4). The lower boundary of Subunit IA was not recovered, and its lower depth was defined on the basis of an underlying lithofacies that contains distinctly fewer fossils (Subunit IB). Subunit IA is composed of grain-supported poorly sorted multicolor bioclast basalt conglomerate (Fig. F5A). The interpebble and intercobble spaces are composed of sandy-pebbly bioclast basalt sediment with a matrix composed of calcite cement and very pale brown foraminifer-bearing micrite. The bioclasts are rounded to well rounded and include shallowmarine biota (e.g., annelids, algae, and shell fragments).

Thin Section 72 (Sample 330-U1373A-1R-1, 8-12 $\mathrm{cm}$ ) indicates that the matrix of the conglomerate includes benthic and planktonic foraminifers and calcispheres, as well as fragments of sponge(?) spicules, echinoderms, annelids, algae, bryozoans, and bivalves. Rare altered fragments of volcanic glass were observed.

\section{Subunit IB}

Interval: Sections 330-U1373A-1R-1, $15 \mathrm{~cm}$, to 1R$3,37 \mathrm{~cm}$

Depth: 0.15-2.66 mbsf

Age: Late Cretaceous or younger

Stratigraphic Subunit IB is at least $2.51 \mathrm{~m}$ thick and extends between 0.15 and 2.66 mbsf (Fig. F4). The lower boundary of Subunit IB was defined by the occurrence of an erosional contact with underlying Subunit IC. Subunit IB is composed of a matrixsupported poorly sorted multicolor basalt conglomerate with few bioclasts (Fig. F5B). The interpebble and intercobble spaces consist of silty-pebbly basalt sediment with a matrix composed of pale brown azoic micrite. The sparse bioclasts have a similar composition but are smaller than those in overlying Subunit IA and underlying Subunit IC. Minor bioturbation of the finer grained sediment and biogenic encrustation of basalt clasts was observed throughout Subunit IB.

Two thin sections (Samples 330-U1373A-1R-2, 7-9 $\mathrm{cm}$ [Thin Section 74], and 1R-2, 45-48 cm [Thin Section 75]) show that the matrix of the basalt sediment (i.e., pale brown micrite) contains a minor clay component not observed elsewhere in the sediment at Site U1373. Volcanic glass fragments and clinopyroxene grains are rare and generally altered. Some of the glass fragments are well-rounded, which attests to relatively significant reworking prior to final deposition in the sediment.

\section{Subunit IC}

Interval: Sections 330-U1373A-1R-3, $37 \mathrm{~cm}$, to 1R$3,76 \mathrm{~cm}$

Depth: 2.66-3.05 mbsf

Age: Late Cretaceous or younger 
Stratigraphic Subunit IC is at least $0.39 \mathrm{~m}$ thick and extends between 2.66 and 3.05 mbsf (Fig. F4). Its lower boundary corresponds to the top of the underlying volcanic interval of lava flows (Unit II). The lithology of Subunit IC is very similar to that of Subunit IA, consisting of grain-supported poorly sorted multicolor bioclast basalt conglomerate (Fig. F5C). The interpebble and intercobble spaces are composed of sandy-pebbly bioclast basalt sediment with a matrix composed of calcite cement and very pale brown micrite. Macroscopic and microscopic observations (Sample 330-U1373A-1R-3, 66-70 cm [Thin Section 77]) indicate that the biogenic content of Subunit IC is also similar to that of Subunit IA. Biogenic encrustation of basalt clasts is common. Rare volcanic glass fragments are commonly completely altered.

\section{Unit II}

Interval: Sections 330-U1373A-2R-1, $0 \mathrm{~cm}$, to 3R-2, $64 \mathrm{~cm}$

Depth: 9.60-15.70 mbsf

Age: Late Cretaceous or younger

Stratigraphic Unit II is $6.10 \mathrm{~m}$ thick and extends between 9.60 and 15.70 mbsf (Fig. F4). Its lower boundary is defined on the basis of bioclast basalt conglomerate that appears in the uppermost part of underlying Unit III. Unit II consists of a volcanic interval composed of three brecciated basalt flows interbedded with basalt breccia. The basalt flows are described in "Igneous petrology and volcanology." Possible mingling textures of the basalt breccia (sediment) with the basalt (lava) occur throughout Unit II. Two thin $(<0.50 \mathrm{~m}$ thick) interbeds of cemented multicolor basalt breccia occur between 10.98 and 11.42 mbsf (interval 330-U1373A-2R-2, 5-49 cm) and between 14.17 and 14.34 mbsf (interval 3R-1, 24 $\mathrm{cm}$, to $4 \mathrm{R}-4,45 \mathrm{~cm}$ ). The breccia is grain supported, poorly sorted, and devoid of biogenic fragments (Fig. F5D). Its maximum clast size is similar to that of Unit I, but the average roundness of the largest clasts is lower than that of Unit I. Unit II is devoid of fossils, and its age was constrained on the basis of paleontological data from underlying Unit III (see "Paleontology") and stratigraphic relationships.

\section{Unit III}

Interval: Sections 330-U1373A-3R-2, $64 \mathrm{~cm}$, to 7R$1,120 \mathrm{~cm}$

Depth: 15.70-33.90 mbsf

Age: Late Cretaceous or younger (Subunit IIIA), between Late Cretaceous and Miocene (Subunit IIIB), and Miocene or older (Subunits IIIC and IIID)
Stratigraphic Unit III is composed of an $18.20 \mathrm{~m}$ thick interval of basalt conglomerate and breccia that extends between 15.70 and 33.90 mbsf (Fig. F4). The unit was divided into four subunits on the basis of distinct sedimentary textures and the abundances of residual pore space, cement, micrite, and bioclasts. The relationship between Subunits IIIB and IIIC and the exact thickness of Subunit IIIB are unknown because interunit contacts were lost as a result of the poor recovery of Core 330-U1373A-4R (22\% recovery). A Late Cretaceous or younger age of deposition was defined on the basis of macrofossil content in Subunit IIIB (see "Paleontology"). Distinct cement textures were recognized in Unit III (Fig. F6), which helped constrain the deposition environments of the sediment (see below). It is important to note, however, that our cement analysis is preliminary. Only the most characteristic textures were described, and additional observations are needed to more accurately characterize the deposition environment of the sediment.

\section{Subunit IIIA}

Interval: Sections 330-U1373A-3R-2, $64 \mathrm{~cm}$, to 3R$3,112 \mathrm{~cm}$

Depth: 15.70-17.07 mbsf

Age: Late Cretaceous or younger

Stratigraphic Subunit IIIA is $1.37 \mathrm{~m}$ thick and extends from 15.70 to 17.07 mbsf (Fig. F4). A transitional contact was observed between Subunits IIIA and IIIB from $\sim 17.02$ to 17.12 mbsf. We defined the lower boundary of Subunit IIIA on the basis of the first occurrence of residual porosity and the layered structure in underlying Subunit IIIB. The composition and texture of Subunit IIIA are similar to those of Subunits IA and IC. Subunit IIIA consists of grainsupported poorly sorted multicolor bioclast basalt conglomerate (Fig. F5E). The interpebble and intercobble spaces include sandy-pebbly bioclast basalt sediment with a matrix composed of calcite cement and a very pale brown micrite. Similar to Subunits IA and IC, Subunit IIIA also includes rounded to wellrounded bioclasts of shallow-marine origin (e.g., annelids, algae, and shell fragments). Bioclasts in Subunit IIIA are, however, larger than those in Subunits IA and IC, with sizes up to $\sim 5 \mathrm{~cm}$. The maximum clast size and clast roundness in Subunit IIIA are similar to those in Subunits IA and IC (pebble to cobble size and subangular to very angular, respectively).

Thin section observations (Samples 330-U1373A-3R3, 10-13 cm [Thin Section 79]; 3R-3, 18-22 cm [Thin Section 80]; and 3R-3, 86-88 cm [Thin Section 81]) indicate that the finer grained sediment is composed of micrite-bearing grainstone with fragments of algae, bivalves, bryozoans, annelids, echinoderms, and 
gastropods, as well as rare benthic foraminifers. The occurrence of granular sparite and micritized cement in pore spaces (showing meniscus and dogtooth textures) suggests a possible intermittent subaerial exposure (Flügel, 1982). Together with observed dissolution features in thin section (Fig. F6A), these occurrences support our conclusion that sediment deposition likely occurred in a marine phreatic environment.

\section{Subunit IIIB}

Interval: Sections 330-U1373A-3R-3, $112 \mathrm{~cm}$, to $4 \mathrm{R}-1,124 \mathrm{~cm}$

Depth: 17.07-23.80 mbsf

Age: between Late Cretaceous and Miocene

Stratigraphic Subunit IIIB is $6.73 \mathrm{~m}$ thick and extends from 17.07 to 23.80 mbsf (Fig. F4). Reduced cementation with depth in Subunit IIIB probably led to poor recovery of Core 330-U1373A-4R (22\% recovery). The lower boundary of Subunit IIIB is believed to correspond to the disappearance with depth of poorly cemented sediment (correlated to an increased recovery rate) and was defined on the basis of the first occurrence in underlying Subunit IIIC of basalt conglomerate poorer in bioclasts. The composition of Subunit IIIB resembles that of overlying Subunit IIIA and consists of grain-supported multicolor bioclast basalt conglomerate (Fig. F5F). However, Subunit IIIB has several distinctive features compared with other sediments at Site U1373: (1) it is very well sorted, (2) grains are rounder, (3) crossbeds and layering structures defined by distinct amounts of volcanic and biogenic grains occur, (4) residual porosity widely occurs, (5) larger bioclasts are more abundant, and (6) biogenic encrustation on both sides of basalt clasts is more abundant. Maximum clast size in Subunit IIIB (granule to boulder size) decreases with depth and is generally lower than that of other units and subunits at Site U1373 (Fig. F4). Similarly, average grain roundness in Subunit IIIB increases with depth from very angular to subrounded. Identification of an extinct oyster (Flemingostrea sp.) suggests the age of Subunit IIIB is between Late Cretaceous and Miocene (see "Paleontology").

Thin section observations (Samples 330-U1373A-3R3, 126-129 cm [Thin Section 82]; 3R-4, 63-68 cm [Thin Section 83]; 4R-1, 72-74 cm [Thin Section 84]; and 4R-1, 86-89 $\mathrm{cm}$ [Thin Section 85]) show that Subunit IIIB is composed of grainstone with fragments of algae, bryozoans, annelids, bivalves, and echinoderms. The occurrence of fibrous meniscus cement and abundant residual porosity (Fig. F6B) indi- cates that sediment was deposited in an intertidal or possibly subtidal environment (Flügel, 1982).

\section{Subunit IIIC}

Interval: Sections 330-U1373A-5R-1, $0 \mathrm{~cm}$, to 6R-1, $105 \mathrm{~cm}$

Depth: 23.80-29.17 mbsf

Age: Miocene or older

Stratigraphic Subunit IIIC is $5.37 \mathrm{~m}$ thick and extends from 23.80 to 29.17 mbsf (Fig. F4). Its lower boundary was defined on the basis of the appearance of matrix-supported dark multicolor basalt breccia in underlying Subunit IIID. The composition of Subunit IIIC ranges from multicolor basalt conglomerate with bioclasts to bluish-gray basalt conglomerate essentially devoid of bioclasts (Fig. F5G). A gradual transition between these two lithologies occurs from 24.19 to 24.29 mbsf (interval 330-U1373A-5R-1, $38.5-48.5 \mathrm{~cm}$ ). The two conglomerate types of Subunit IIIC are poorly sorted and grain supported, and both have a bimodal grain size distribution and contain well-rounded basalt clasts. The multicolor basalt conglomerate has a matrix composed of cement, very pale brown micrite, and bioclast basalt sandstone conglomerate. This conglomerate also has a higher content of echinoderm fragments than other sediments at Site U1373. On the other hand, the bluish-gray basalt conglomerate has cemented pores and is devoid of micrite. Bioclast content in Subunit IIIC decreases sharply at the transition between the multicolor and bluish-gray basalt conglomerates. Bioclasts were not found below 24.49 mbsf at Site U1373. In Subunit IIIC, maximum clast size ranges from pebble to cobble size, with subangular to wellrounded average grain roundness.

Thin section observations (Samples 330-U1373A-5R1, 33-36 cm [Thin Section 86], and 5R-1, 101-104 $\mathrm{cm}$ [Thin Section 87]) show that the bioclast content in Subunit IIIC is similar to that of other bioclastbearing sediments at Site U1373. The occurrence of dogtooth, meniscus, and granular cements, as well as vadose silt, dissolved shell fragments, and residual porosity (Fig. F6C, F6D, F6F), supports deposition of the upper part of Subunit IIIC (i.e., multicolor basalt conglomerate with bioclasts) in an intertidal or possibly subtidal environment (Flügel, 1982). Pore spaces in the lower part of the subunit (i.e., bluishgray basalt conglomerate) are composed of micrite with possible meniscus texture, rim cement, and granular cement (Fig. F6E), which suggests that the sediment was deposited similarly in an intertidal and possibly subtidal to marine phreatic environment (Flügel, 1982). 


\section{Subunit IIID}

Interval: Sections 330-U1373A-6R-1, $105 \mathrm{~cm}$, to 7R-1, $120 \mathrm{~cm}$

Depth: 29.17-33.90 mbsf

Age: Miocene or older

Stratigraphic Subunit IIID is $4.73 \mathrm{~m}$ thick and extends from 29.17 to 33.90 mbsf (Fig. F4). Its lower boundary corresponds to the uppermost part of the underlying volcanic basement sequence (see "Igneous petrology and volcanology"). Subunit IIID includes a poorly sorted matrix-supported dark multicolor basalt breccia devoid of bioclasts and carbonate, with a matrix composition ranging between dark gray siltstone and finer grained basalt breccia. The maximum clast size in Subunit IIID ranges between pebble and boulder size, with angular to subangular average grain roundness. The basalt clast composition is dissimilar to that of Unit I and Subunits IIIA-IIIC, with occurrences of clast Types 10-12 and the absence of Types 1-6 (Table T2).

Thin section observation (Sample 330-U1373A-6R-2, $39-43 \mathrm{~cm}$ [Thin Section 88]) indicates that the sediment matrix is predominantly composed of altered glass fragments possibly replaced by clay minerals (Fig. F7).

\section{Sediment in underlying volcanic sequence}

The volcanic sequence starting with Unit IV includes several enclaves and interbeds of sediment at 37.9137.94 mbsf (interval 330-U1373A-8R-1, 51-54 cm), 38.36-38.39 mbsf (interval 330-U1373A-8R-1, 96-99 $\mathrm{cm}$ ), 38.82-40.27 mbsf (interval 330-U1373A-8R-2, 0-145 cm), and 43.96-44.21 mbsf (interval 330U1373A-9R-2, 65-90 cm). The sediment consists of dark multicolor basalt siltstone-sandstone devoid of bioclasts and carbonate. Primary sedimentary structures within the sediment interbeds survived synvolcanic deformation and include moderately deformed laminae and fining-upward grain structures.

Thin section observation (Sample 330-U1373A-9R-2, 76-79 cm [Thin Section 100]) shows that the composition of the fine-grained sediment is similar to that of the matrix of the dark multicolor basalt breccia encountered in Subunit IIID, predominantly altered glass fragments possibly replaced by clay minerals (Fig. F7).

\section{Interpretation of lithologies and lithofacies at Site U1373}

Seven lithofacies were recognized in the basalt conglomerate and breccia at Site U1373, permitting overall characterization of the environment of deposition (Figs. F4, F5, F6). Lithofacies 1 was found in Subunit IIIB and is characterized by (1) current struc- ture at macroscopic and microscopic scales, (2) very well sorted grains, (3) generally well rounded grains, (4) increased occurrence of shallow-marine bioclasts relative to other sediments at Site U1373, and (5) cement textures (Fig. F6E) and high residual porosity indicative of an intertidal environment of deposition (Flügel, 1982). The conjunction of these characteristics supports sediment deposition in a beach environment. Lithofacies 2 corresponds to Subunits IA, IC, and IIIA. This lithofacies was interpreted to reflect sediment deposition in a shallow-marine and subtidal or intertidal environment on the basis of highly abundant shallow-marine bioclasts and the dissolution of some bioclasts and cement textures (Fig. F6A). Lithofacies 3 (upper part of Subunit IIIC only) is defined by the occurrence of shallow-marine bioclasts and meniscus, dogtooth, and dripstone cement textures (Fig. F6C, F6D, F6F). It is interpreted to represent an intertidal and subtidal environment of sediment deposition similar to that suggested by Lithofacies 2. However, clearer indications for cementation in an intertidal or possibly vadose environment were found in Lithofacies 3 (Point 1 in Fig. F6C, F6D). Lithofacies 4 (lower part of Subunit IIIC) corresponds to a cemented basalt conglomerate mostly devoid of micrite and bioclasts. Although clear discriminative criteria of the environment of deposition were not found, we tentatively propose that Lithofacies 4 reflects sediment deposition in a shallow-marine environment. The absence of bioclasts in the lower part of Subunit IIIC, deposition of overlying sediment in an intertidal-subtidal environment, and emplacement of underlying lava flows in subaerial conditions (see "Igneous petrology and volcanology") suggest that Lithofacies 4 possibly records a subaerial to submarine transition. Lithofacies 5 corresponds to the basalt conglomerate of Subunit IB, which is interpreted as a mudflow deposited in a shallow-marine environment on the basis of (1) clay content in the conglomerate matrix, (2) matrix-supported texture of the conglomerate, and (3) bioclasts of shallow-marine origin and micrite embedded in the matrix of the conglomerate. Lithofacies 6 corresponds to the dark basalt conglomerate found in Subunit IIID and interbeds/enclaves of sediment in the underlying volcanic sequence. The sediment was interpreted as a matrix-supported debris flow deposit. Its textural and compositional characteristics include high angularity of basalt clasts, matrix-supported sedimentary texture, a lack of bioclasts, and predominant occurrence of altered ash and finegrained vitric fragments without carbonate in the sediment matrix. These observations suggest that the sediment could represent a lahar deposit. Lithofacies 7 corresponds to interbeds of basalt breccia in Unit II (in an intermediate volcanic interval). It is character- 
ized by a lack of bioclasts and high textural variability of the basalt clasts. These observations and the stratigraphic relationship of the volcanic interval with Units I and III suggest that the breccia represents proximal debris flows of Unit II emplaced in a shallow-marine environment.

In summary, the sediment of Site U1373 defines a shallow-marine to beach environment of deposition on a previously volcanic island. We propose that the background sedimentation of shallow-marine conglomerate (Lithofacies 1-4) was punctuated by catastrophic emplacement of a mudflow deposit, a volcanic interval, and possible lahar deposit(s) (Lithofacies 5-7). The recurrence of such catastrophic deposits suggests that the environment of deposition was perhaps located close to the bottom of a valley, most likely close to a fluvial fan. Unlike Site U1372 on Canopus Guyot, no evidence for subsidence or significant eustatic change was found.

\section{Paleontology}

Despite the fact that a veneer of unconsolidated pelagic sediment was observed on the seafloor before spotting Hole U1373A (using the vibration-isolated television camera; see "Operations") Core 330U1373A-1R was composed of consolidated basalt conglomerate (Unit I; see "Sedimentology"). Nonetheless, a small sample of sand- and granule-size angular grains with planktonic foraminiferal tests and nannofossils was recovered from the core catcher of Core $1 \mathrm{R}$. These grains are composed of basalt fragments, feldspar crystals, foraminiferal tests, glass fragments, ferromanganese crust, olivine crystals, and some other minor crystals. Linear scratches were observed on the surface of many of these lithic grains, indicating mechanical abrasion during drilling. Because no drilling mud was pumped during the drilling of Cores $1 \mathrm{R}, 2 \mathrm{R}$, or $3 \mathrm{R}$, these sand- and granule-size grains are assumed to be a mixture of cuttings from Core $1 \mathrm{R}$ and surface sediment. The preliminary age assigned to these cuttings is Pleistocene-Holocene.

Instead of conducting microfossil analyses on soft sediment, which is standard procedure, we analyzed thin sections for microfossil biostratigraphy in the consolidated sequences of Units I and III. In addition to these microfossil analyses, macrofossils embedded in Subunit IIIB were examined. These macrofossils were identified as Flemingostrea sp. (an oyster), which has a long biostratigraphic age range of Late Cretaceous-Miocene and provides the preliminary age of Subunit IIIB. Preliminary age assignments are summarized in Figure F8 and Tables T3 and T4.

\section{Calcareous nannofossils}

Nannofossil analysis in Hole U1373A was restricted to a small percentage of sediment (no more than $50 \mathrm{~cm}^{3}$ ) recovered at the bottom of the core catcher of Core 330-U1373A-1R. No stratigraphic unit or subunit was therefore assigned to this small amount of recovered material. This material is assumed to have settled out from the seawater in the core liner and likely represents unsampled oozy sediment observed during site spotting on top of the drilled guyot. The observed assemblage contained Neogene background species Helicosphaera kamptneri and Calcidiscus leptoporus. Common species include small Gephyrocapsa, Pseudoemiliania lacunosa, and Emiliania huxleyi. Rare specimens of Gephyrocapsa caribbeanica were also observed, the first occurrence of which suggests a lower limit of Subzone CN13b. On the basis of this lower CN13b limit and the disturbed nature of the recovered sediment, a range of Zones CN13b-CN15 (lower Pleistocene to Holocene) was assigned as the age of the sediment overlying Subunit IA (Fig. F8; Table T3).

\section{Planktonic foraminifers}

Rock cuttings from Core 330-U1373A-1R and the less consolidated basalt conglomerate of Subunit IIIB were used for planktonic foraminiferal analyses. Zonal assignments are summarized in Figure F8 and Table T4. Sample 1R-3, 14-16 cm (2.43-2.45 mbsf), from Unit I contains Globorotalia (Globoconella) inflata, Globorotalia (Truncorotalia) crassaformis, Globorotalia (Truncorotalia) truncatulinoides, and Sphaeroidinella dehiscens (Table T4). Although many grains in the cuttings show linear tool marks on their surfaces under binocular microscope observation, relatively well preserved foraminifers were found in those cuttings. Some foraminiferal tests are brownish, but most are free from calcite cement and are white. Foraminiferal tests compose $10 \%-20 \%$ of the grains. On the basis of the occurrence of Gr. (T.) truncatulinoides, the preliminary age for this sample is correlated to Zone PL6-PT1b (Pleistocene-Holocene). However, because the sample was derived from a very small amount of surface sediment, no stratigraphic unit or subunit was assigned to this material.

Sample 330-U1373A-4R-1, 99-100 cm (19.56-19.60 mbsf), of Subunit IIIB contains no planktonic foraminifers. The disaggregated grains of this sample are mainly composed of altered basalt, altered glass, and calcite cement fragments with minor bioclasts. Among these bioclasts, calcareous algae and sea urchin spines are common, with a few benthic foraminifers. All of these benthic foraminifers are filled 
with calcite cement, and their tests are often dissolved.

In addition to these analyses, thin sections taken from Samples 330-U1373A-1R-1W, 8-12 cm; 1R-2W, 7-9 cm; and 1R-3W, 66-70 cm (Unit I); 3R-3W, 10$13 \mathrm{~cm}$ (Subunit IIIA); 3R-3W, 126-129 cm, and 4R1W, 72-74 cm (Subunit IIIB); 5R-1W, 33-36 cm (Subunit IIIC); and 6R-2W, 39-43 cm (Subunit IIID) were examined. Samples from Units I and III contain abundant bioclasts within the volcaniclastic matrix (see "Sedimentology"). Benthic foraminifers, bivalve fragments, bryozoans, calcareous algae, and sea urchin spines were generally identified in these samples. On the other hand, only Samples 1R-1W, 8-12 $\mathrm{cm}$, and $1 \mathrm{R}-2 \mathrm{~W}, 7-9 \mathrm{~cm}$, from Unit I rarely contain planktonic foraminifers. However, none of these planktonic foraminifers were sectioned in the axial plane in thin section, which is required for species identification. In addition, some of the planktonic foraminifers were fractured, and shell microstructures such as pores were not visible in any of the specimens, indicating that the preservation of foraminiferal tests is poor in Unit I. Because of the tests' poor preservation, species identification was difficult. Although one single-keeled morphotype was identified in Sample 1R-1W, 8-12 cm (Subunit IA), all other observed foraminifers in Units I and III show globular or biserial morphologies. Therefore, the preliminary ages of Units I and III could not be identified by onboard analyses and will be examined postexpedition.

\section{Macrofossils}

Well-diversified bioclasts including macrofossils occur in Subunit IIIB. Although most of the macrofossils are fragmented and unidentifiable, some wellpreserved fossils were found in Section 330-U1373A4R-1 (Fig. F9). Shell height of the specimen shown in Figure F9A is $>4 \mathrm{~cm}$, and the valve is slightly convex in the outer mold of the anterior view. Multiple imbrications were identified on the anterior and external views (Fig. F9A, F9B). Thin section observations of the specimen shown in Figure F9B indicate that the multiple imbrications are composed of numerous prismatic shell layers (Fig. F10). On the basis of these morphological characteristics, these individuals were identified as Flemingostrea sp., a marine oyster. The total range of this genus is from the Late Cretaceous to Miocene, and its acme was in the Late Cretaceous (Stenzel et al., 1971). Therefore, Subunit IIIB can be correlated to this long interval. However, because the occurrence of this genus has been reported in the Eocene of New Zealand (Beu and Raine, 2009), Subunit IIIB might be correlated to the Eocene (55.8-33.9 Ma) as well.

\section{Igneous petrology and volcanology}

A total of $37.9 \mathrm{~m}$ of igneous rocks was penetrated in Hole U1373A. These rocks include $6.1 \mathrm{~m}$ of autobrecciated lava flows, which make up Unit II of the sedimentary cover, and $31.8 \mathrm{~m}$ of igneous basement from the base of the sedimentary succession at 33.9 mbsf to the bottom of the hole at 65.7 mbsf. Sedimentary stratigraphic Units I and III are conglomerate and breccia composed largely of pebble- to boulder-size basaltic clasts in a sandy matrix (see "Sedimentology"). The basaltic clast types are described below. Stratigraphic Unit II is made up of highly brecciated basalt with some massive intervals and was divided into five lithologic units. These units were defined on the basis of clast type and phenocryst abundance and range in thickness from $43 \mathrm{~cm}$ to $2.75 \mathrm{~m}$ (Fig. F11). The recovered igneous basement section (below $33.91 \mathrm{mbsf}$ ) was divided into 10 additional lithologic units, giving a total of 15 igneous lithologic units (numbered 1-15) ranging in thickness from $24 \mathrm{~cm}$ to $22.17 \mathrm{~m}$. The 10 basement lithologic units are grouped into four stratigraphic units (Units IV-VII) ranging in thickness from 1.48 to $22.86 \mathrm{~m}$ (Fig. F11). To help achieve the paleomagnetic objectives of this expedition, we determined the in situ confidence index (ISCI) for each lava cooling unit by following the procedures described in "Igneous petrology and volcanology" in the "Methods" chapter (Expedition 330 Scientists, 2012a). A summary of the lithologic units and their ISCIs is given in Table T5.

\section{Basaltic clasts in sedimentary Units I and III}

The larger basaltic clasts within the conglomerate and breccia were divided into 12 types on the basis of their appearance in hand specimen. Each clast type is described below, and the sedimentologic subunit(s) in which each clast type was found is also noted (see "Sedimentology"):

- Type 1 (Subunits IA, IB, IIIA, and IIIC): moderately plagioclase-olivine-phyric basalt that is fine grained and light reddish gray, with $3 \%$ plagioclase phenocrysts (maximum size $=1.5 \mathrm{~mm}$, modal size $=1 \mathrm{~mm}), 1 \%$ olivine phenocrysts (completely altered; maximum size $=2 \mathrm{~mm}$, modal size $=1.5 \mathrm{~mm}$ ), and $3 \%$ vesicles (elongate, subangular).

- Type 2 (Subunits IA, IB, IIIA, IIIB, IIIC, and IIID): aphyric basalt that is fine grained and gray-brown, with $0 \%-10 \%$ vesicles (elongate, subrounded).

- Type 3 (Subunits IB, IIIA, and IIIB): aphyric basalt that is fine grained and light gray, with $1 \%$ olivine 
microphenocrysts (altered; maximum size $=0.5$ $\mathrm{mm}$, modal size $=0.2 \mathrm{~mm}$ ) and $15 \%$ vesicles (elongate, subrounded).

- Type 4 (Subunits IB, IIIA, and IIIC): highly olivinephyric basalt that is fine grained and orange-light gray, with $20 \%$ olivine phenocrysts (maximum size $=5 \mathrm{~mm}$, modal size $=2 \mathrm{~mm}$ ) and $3 \%$ vesicles (moderate sphericity, subrounded).

- Type 5 (Subunits IB, IC, IIIA, and IIIB): aphyric basalt that is fine grained and blue-gray/reddish gray, with $0.5 \%$ olivine microphenocrysts (altered), $0.2 \%$ pyroxene microphenocrysts, and $15 \%$ vesicles (elongate, subrounded).

- Type 6 (Subunits IB, IIIA, IIIB, and IIIC): moderately plagioclase-phyric basalt that is fine grained and medium gray, with $5 \%$ plagioclase phenocrysts (maximum size $=1.2 \mathrm{~mm}$, modal size $=1.0$ $\mathrm{mm}), 1 \%$ olivine microphenocrysts, and $10 \%$ vesicles (low sphericity, subrounded).

- Type 7 (Subunits IB, IIIB, IIIC, and IIID): distinctive highly olivine-pyroxene-plagioclase-phyric basalt that is fine grained and medium gray, with $7 \%$ olivine phenocrysts (maximum size $=5 \mathrm{~mm}$, modal size $=3 \mathrm{~mm}$ ), $5 \%$ pyroxene phenocrysts (one clast in Subunit IIID is more pyroxene-rich and less olivine-rich) (maximum size $=8 \mathrm{~mm}$, modal size $=4 \mathrm{~mm}), 1 \%$ plagioclase phenocrysts (maximum size $=3 \mathrm{~mm}$, modal size $=1 \mathrm{~mm})$, and $0 \%$ vesicles (3\%-10\% vesicular in Subunit IIID).

- Type 8 (Subunits IIIA and IIIB): aphyric basalt that is fine grained and brown-orange gray, with $10 \%$ vesicles (elongate, subangular).

- Type 9 (Subunit IIIC): highly plagioclase-phyric basalt that is fine grained and medium gray, with $10 \%$ plagioclase phenocrysts (maximum size $=2.5$ $\mathrm{mm}$, modal size $=1.5 \mathrm{~mm}$ ) and $1 \%$ vesicles (high sphericity, rounded).

- Type 10 (Subunit IIIC): aphyric basalt that is fine grained and pale orange-gray, with $15 \%$ vesicles (low sphericity, subrounded).

- Type 11 (Subunit IIID): aphyric basalt that is fine grained and medium gray, with plagioclase microphenocrysts in the groundmass and 10\% vesicles (low sphericity to elongate, subrounded)

- Type 12 (Subunit IIID): aphyric basalt that is fine grained and brownish red, with $0.5 \%$ vesicles (low sphericity to elongate, subrounded).

Although many of the clast types were found throughout most of the breccia and conglomerate sedimentary sequence in Units I and III, no individual clast type was found to occur in all of the subunits. The most common were the Type 2 aphyric basalt clasts and the distinctive porphyritic Type 7 highly olivine-pyroxene-plagioclase-phyric basalt clasts. Although similar in appearance to the basalt that makes up the two Unit IV flows at the top of the igneous basement, clast Type 7 differs slightly in that it contains plagioclase phenocrysts. A thin section photomicrograph taken from a particularly unaltered example of a Type 7 clast from Subunit IB is shown in Figure F12. One olivine crystal in this thin section shows well-developed strain lamellae (Fig. F13), suggesting that this crystal was entrained from a deformed cumulate pile beneath the volcano.

Most of the clasts are rounded to subangular and have clearly been transported and abraded. Some of the Type 2 aphyric basalt clasts in Subunit IB, however, have lobate, fluidal, or amoeboid outlines, often with delicate protrusions (Fig. F14), and therefore could not have traveled far from their in situ emplacement position. Some of the Type 2 clasts closely resemble the fluidal clasts typical of some peperites (Skilling et al., 2002), and the significance of this will be discussed later.

\section{Lithologic and stratigraphic igneous units}

\section{Unit II}

Interval: Sections 330-U1373A-2R-1, $0 \mathrm{~cm}$, to 3R-2, $64 \mathrm{~cm}$

Depth: 9.6-15.7 mbsf

Lithology: volcanic breccia with polylithic breccia interbeds

Lithologic units: $1-5$

Unit II is composed mostly of clast-supported basaltic breccia with some intervals of massive basalt. The breccia comprises angular clasts (typically $\sim 50 \mathrm{~mm}$ in size), interstitial basaltic sand, and carbonate cement. The clasts frequently fit together as jigsaw-fit breccia (Fig. F15), showing that the breccia formed more or less in situ. Two intervals of grain-supported polylithic breccia are interbedded with the volcanic breccia units (see "Sedimentology"). These intervals have more rounded and weathered clasts and are interpreted as sedimentary units. The basalt forming the breccia varies from aphyric to moderately olivine- and olivine-augite-phyric, but phenocryst type and abundance are fairly constant over discrete intervals. Phenocryst type and abundance were used as the principal criteria for dividing Unit II into five igneous lithologic units, although lithologic Unit 2 and the upper $17 \mathrm{~cm}$ of lithologic Unit 4 are polylithic and have therefore been included with the sedimentary rocks (Fig. F11; Table T5; see also "Sedimentology").

\section{Unit IV}

Interval: Sections 330-U1373A-7R-1, $121 \mathrm{~cm}$, to 7R-3, $123 \mathrm{~cm}$

Depth: 33.91-36.66 mbsf 
Lithology: highly olivine-augite-phyric basalt Lithologic units: 6-7

Unit IV is $2.75 \mathrm{~m}$ thick and comprises two highly olivine-augite-phyric basalt flows that contain $7 \%$ olivine and $4 \%$ augite phenocrysts within nonvesicular groundmass (Fig. F16). The two flows are separated by a $10 \mathrm{~cm}$ thick interval of volcanic breccia that may separate two lithologically identical lobes of the same eruptive unit. The top of Unit IV is in contact with the sedimentary cover (see "Sedimentology") at Section 330-U1373A-7R-1, $121 \mathrm{~cm}$, but the contact between Unit IV and underlying Unit $\mathrm{V}$ was not recovered. This lower boundary was inferred from the disappearance of the olivine and augite phenocrysts between Sections 330-U1373A-7R-4 and 7R-5. Core recovery in Unit IV was almost complete.

\section{Unit V}

Interval: Sections 330-U1373A-7R-4, $0 \mathrm{~cm}$, to 7R-5, $5.5 \mathrm{~cm}$

Depth: 36.66-38.14 mbsf

Lithology: aphyric basalt

Lithologic units: 8-10

Unit $\mathrm{V}$ is a $1.48 \mathrm{~m}$ package of thin aphyric basalt lava lobes. The upper lithologic Unit 8 is $24 \mathrm{~cm}$ thick and vesicular and contains $0.5 \%$ olivine phenocrysts. It has a thin $(\sim 1 \mathrm{~cm})$ sediment layer at its top and is separated from the underlying unit by another thin $(\sim 1 \mathrm{~cm})$ layer of brown sediment. Lithologic Unit 9 is $63 \mathrm{~cm}$ thick and vesicular and contains $0.5 \%$ olivine phenocrysts. It has a $2 \mathrm{~cm}$ thick sediment interval at its base. Lithologic Unit 10, at the base of Unit V, is peperitic and vesicular and contains $1 \%$ olivine phenocrysts. The lower boundary of Unit $\mathrm{V}$ is defined by a thin red oxidized layer, which separates these aphyric flows from the sparsely phyric flows below. The presence of the oxidized flow top implies subaerial eruption. Core recovery across Unit V was excellent $(>100 \%)$.

\section{Unit VI}

Interval: Sections 330-U1373A-7R-5, $5.5 \mathrm{~cm}$, to 9R$1,121 \mathrm{~cm}$

Depth: 38.14-43.31 mbsf

Lithology: sparsely olivine-phyric basalt

Lithologic units: 11-13

Unit VI is $5.17 \mathrm{~m}$ thick and made up of three sparsely olivine-phyric basalt lava flows separated by oxidized layers. Each lithologic unit includes peperitic intervals. The upper flow (lithologic Unit 11) is peperitic throughout its $91 \mathrm{~cm}$ thickness and has a red oxidized top. The larger pods of green coarse sandstone show squeezing features and compaction swales. The basalt is highly vesicular and contains
$1 \%$ olivine and $0.5 \%$ plagioclase phenocrysts. The middle flow (lithologic Unit 12) is $1.97 \mathrm{~m}$ thick and is also peperitic with a vesicular core. Lithologic Unit 13 is a $2.29 \mathrm{~m}$ thick peperitic lava flow that has $0.5 \%$ plagioclase and $0.5 \%$ pyroxene microphenocrysts that occur as glomerocrysts. It also contains sparse olivine microphenocrysts, which distinguishes it from the aphyric flow below and justifies its inclusion in Unit VI. This unit has a vesicular core and a scoriaceous and peperitic top and base. Its bottom contact, and thus the bottom of Unit VI, was not recovered but was inferred from the disappearance of olivine microphenocrysts and a return to an aphyric texture. Unit VI has excellent (96\% average) core recovery.

\section{Unit VII}

Interval: Sections 330-U1373A-9R-2, $0 \mathrm{~cm}$, to 13R$4,117 \mathrm{~cm}$

Depth: 43.31-65.7 mbsf

Lithology: aphyric basalt

Lithologic units: $14-15$

Unit VII is $22.4 \mathrm{~m}$ thick and consists of two aphyric basalt lava flows, both of which are peperitic. Lithologic Unit 14 is a thin (67 cm recovered) unit and is peperitic in its uppermost $32 \mathrm{~cm}$, whereas the lower part of the flow is vesicular and has a distinct horizontal foliation. Lithologic Unit 15 is at least $21.7 \mathrm{~m}$ thick. Drilling stopped within this flow, so its overall thickness is unknown. The upper $22 \mathrm{~cm}$ of the flow is peperitic and composed of approximately equal amounts of green coarse sand mingled with vesicular aphyric basalt (Fig. F17). This peperitic interval grades into a $113 \mathrm{~cm}$ thick zone with aligned vesicles, which in turn grades into massive basalt that extends through the rest of Unit VII. Across interval $330-\mathrm{U} 1373 \mathrm{~A}-13 \mathrm{R}-1,28-38 \mathrm{~cm}$, there is a moderately olivine-pyroxene-plagioclase-phyric patch with 1.5$2 \mathrm{~mm}$ phenocrysts. Core recovery in this unit was very good ( $87 \%$ average).

\section{Interpretation of the igneous succession}

The igneous rocks encountered in Hole U1373A are interpreted in chronological order (oldest first, from the bottom of the hole). The inflated aphyric sheet flow of lithologic Unit 15, which makes up most of Unit VII, is the lowest unit in the drilled succession. The peperitic top of this flow (Fig. F17) suggests that it initially flowed into and mingled with wet sediment. A continued supply of magma resulted in periodic inflation of the flow, evidence for which is provided by vesicular patches and trails (including pipe vesicles) at several intervals throughout the unit. The presence of peperite in the top half of the overlying, much smaller flow might imply continued sedimen- 
tation after emplacement of the larger lava flow. Alternatively, the upper flow might simply be a smaller lobe formed during the same eruption. The subsequent flows that form Unit VI and the lower part of Unit $\mathrm{V}$ are also peperitic, in some cases almost entirely so, suggesting that sedimentation persisted for a while at Site U1373. Following the last occurrence of peperite in the lower part of Unit V, the lava flows become more massive and have oxidized tops, suggesting that the upper part of Unit $\mathrm{V}$ and all of Unit IV were likely erupted and emplaced under fully subaerial conditions.

A sedimentary succession of breccia and conglomerate (Unit III) follows the volcanic rocks of Units VIIIV. The breccia is interpreted as a lahar deposit and the conglomerate as fluvial or intertidal deposits (see "Sedimentology"). This coarse clastic sedimentation was interrupted by the emplacement of autobrecciated lava flows forming Unit II. These flows are almost entirely brecciated, but the fragments appear to fit together in places and give the breccia a jigsaw-fit texture (Fig. F15). This is a common feature of blocky peperites and is widely inferred to reflect in situ quench fragmentation (e.g., Kokelaar, 1982). Busby-Spera and White (1987) suggest that the development of peperite with blocky clasts is favored by emplacement of magma into sediment with coarse grain size, high permeability, and poor sorting, all of which are features of the Unit III conglomerate. By contrast, fluidal, globular, and lobate peperite textures imply ductile fragmentation in situations where magma and sediment are separated by thin films of superheated water vapor (Skilling et al., 2002). This style of peperite formation is favored when magma is emplaced into fine-grained, wellsorted sediment with low porosity, such as micrite (Busby-Spera and White, 1987). The peperites at the top of Unit VII (Fig. F17) and in the uppermost lava flows in Hole U1372A (see Fig. F20 in the "Site U1372" chapter [Expedition 330 Scientists, 2012b]) are of this type.

Uppermost stratigraphic Unit I is again composed of conglomerate with basalt clasts, some of which have lobate margins with delicate protrusions and therefore cannot have been transported far from their source. They may indicate syndepositional, peperitic interaction of lava and sediment, implying a late phase of volcanism contemporaneous with the formation of Unit I.

We conclude that the volcanological features of the igneous rocks in Hole U1373A suggest lava flowing into an area where water and water-saturated sediments were present but which was not fully submarine. Lava flows forming the upper part of Unit $\mathrm{V}$ and all of Unit IV have oxidized tops and show no evidence for water-lava or water-wet sediment interaction. Emplacement of lava flows in an intertidal or fluvial environment provides a plausible scenario that is entirely consistent with sedimentologic observations (see "Sedimentology"). The absence of thick volcaniclastic deposits at Site U1373 (in contrast to Site U1372) supports the scenario that the site of lava effusion, if not emplacement, was mostly subaerial throughout the time interval represented by the Site U1373 cores.

The thick, lowermost Unit VII is aphyric, whereas the two overlying units are aphyric or sparsely olivine-phyric. In contrast, Unit IV is a distinctive highly olivine-augite-phyric basalt. Groundmass augite and the rims of augite phenocrysts in Unit IV, and in the highly olivine-augite phyric clasts in the overlying conglomerate, have the distinctive purple color of titanaugite. The presence of titanaugite and the olivine-titanaugite phenocryst assemblage are characteristic of alkalic basalts.

\section{Alteration petrology}

Seven stratigraphic units were identified at Site U1373, comprising two sedimentary and five igneous units (see "Sedimentology" and "Igneous petrology and volcanology"). Overall alteration of volcanic rocks from Hole U1373A ranges from slight to high (10\%-95\%; Fig. F18), as estimated from core descriptions and thin section observations. Alteration at Site U1373 resulted in variable amounts of replacement of olivine and volcanic glass. Plagioclase phenocrysts and groundmass crystals have minor alteration to sericite/illite in some rocks but characteristically are unaltered. Augite is almost always unaltered. Olivine is typically completely altered to iddingsite and hematite in the uppermost $30 \mathrm{~m}$ of core, and at greater depths is primarily replaced by Fe oxyhydroxide, green clay, and carbonate minerals (Figs. F19, F20, F21, F22). Nevertheless, fresh olivine was found in a Type 7 clast in Unit I, and moderately fresh olivine occurs in Units IV-VI. No fresh glass was encountered in Hole U1373A.

\section{Alteration phases}

We distinguished three main groups of alteration phases in Hole U1373A:

1. Phyllosilicate minerals (saponite, nontronite, montmorillonite, celadonite, and bannisterite) are abundant secondary phases and were identified using optical microscopy and X-ray diffraction (XRD).

2. Carbonates are also abundant secondary minerals as infillings in vesicles, vugs, and veins. XRD analyses on whole rocks, veins, and vesicles sug- 
gest a predominance of $\mathrm{Mg}$ calcite and minor aragonite (interval 330-U1373A-10R-2, 108-110 cm; Figs. F23, F24).

3. Other secondary phases are mostly zeolites (chabazite, phillipsite, and natrolite, especially in vesicles and vugs; Figs. F25, F26) and iddingsite, hematite, Fe oxyhydroxides, clinochlore, some pyrite/chalcopyrite, and goethite.

\section{Overall alteration characteristics}

The overall alteration of groundmass ranges from $10 \%$ to $95 \%$, as estimated by visual observations (Fig. F18). In the uppermost $5 \mathrm{~m}$ of Hole U1373A (Units I and III), the groundmass alteration of basaltic clasts is quite homogeneous, regardless of the heterogeneity of these clasts in the sedimentary units. The volcanic breccia of Unit II is highly altered (70\%-95\%) with a brownish color. Basalt flows from Unit IV are characterized by slightly altered groundmass (10\%), whereas the deeper Units $\mathrm{V}$ and VI are more altered (20\%-70\%) and brownish. Units V and VI are separated by a thin oxidized weathering surface. The lowermost recovered Unit VII consists of two massive aphyric basalt lava flows that are nearly fresh $(10 \%$ alteration) with a gray groundmass.

On the basis of core descriptions and thin section observations, two types of pervasive alteration were identified on the basis of alteration color. In addition to the relatively unaltered light to dark gray basalt cored from Hole U1373A, two general color groups were identified: one with a slight greenish alteration color and one with a slight brown/red color. Representative logs displaying the distribution of alteration colors with depth are given in Figures F27 and F28.

\section{Grayish-brown/reddish-brown alteration}

Grayish-brown to reddish-brown alteration occurs mainly in the uppermost $45 \mathrm{~m}$ of Hole U1373A in the basalt breccia (volcanic clasts from Units I and III) and through the succession of peperitic flows from Units V-VI. This alteration is characterized by carbonates, zeolites, and minor brown clay minerals. Olivine is mostly altered to iddingsite, hematite, Fe oxyhydroxides, and brown clay minerals (Fig. F21). However, in Units III and IV olivine is mostly altered to green clay and Fe oxides, with thin rims of iddingsite.

\section{Gray basalt with slight greenish alteration}

Gray basalt is encountered in Unit IV and below 45 mbsf in Unit VII. This basalt is only slightly altered, and because of the massive nature of the unit, alteration appears to be quite consistent. The groundmass of this gray basalt is slightly altered to fine-grained brown and green minerals that are difficult to identify in thin section are referred to simply as clay minerals or palagonite. Pyroxene and plagioclase are relatively fresh, and olivine is often partially replaced by green clay and Fe oxides (Fig. F20). Blue clay minerals (smectite) are present as coatings in many vesicles and voids throughout the lower portion of the core (Fig. F25).

\section{Vesicle infillings}

The basaltic rocks from Site U1373 vary in vesicularity (see "Structural geology" and "Igneous petrology and volcanology"). In general, vesicularity peaks at $20 \%-50 \%$ abundance in the lower part of Unit III through Unit VI. Deeper than $\sim 48 \mathrm{mbsf}$ (Unit VII) the vesicle abundance becomes very low $(<10 \%)$.

Many vesicles are partially filled with secondary minerals (Figs. F29, F30, F31), but the vesicles in clasts from Units I and II and in the aphyric basalt from Unit VII are typically fully filled. Optical microscopic observations as well as XRD data indicate that the vesicle infilling material is often a mixture of secondary minerals (Fig. F30). Basalt conglomerates and breccia (Units I and III) generally have calcite and minor zeolite vesicle infillings. Deeper than 37 mbsf, the amount of calcite in the vesicles decreases, with zeolites and green clay being the dominant vesiclefilling minerals. In this interval, many vesicles are composite, with clay minerals coating the walls of vesicles (Fig. F30A, F30B) that were subsequently infilled by well-formed crystals of zeolite (Fig. F30C, F30D). Occasionally, Fe oxyhydroxides appear in these lower units, and we notably observed goethite in interval 330-U1373A-7R-4, 108-110 cm (Fig. F31F). Blue clay linings of vesicles are especially abundant in the peperitic parts of Units V-VII (Figs. F23, F30F). XRD analyses of vesicle infilling material of Units IV-VII showed a mixture of different minerals such as zeolite (chabazite, phillipsite, and natrolite) and $\mathrm{Mg}$ calcite. Other minerals in these vesicles are usually smectite (Section 330-U1373A-8R-2, 29 $\mathrm{cm}$ ) as well as chlorite (clinochlore; Sections 330U1373A-7R-4, $39 \mathrm{~cm}$, and 9R-1, $102 \mathrm{~cm})$. Selected XRD spectra are shown in Figures F23, F25, and F26.

\section{Vein infillings}

A total of 291 filled or partly filled veins were counted, yielding an average of 4.4 veins per meter (see "Structural geology"). These veins are mostly small fractures $(\sim 1 \mathrm{~mm})$ filled with clay minerals and carbonates. An exception is a higher abundance of slightly thicker veins (up to $9 \mathrm{~mm}$ ) in Unit IV. Additionally, Unit IV has a higher abundance of veins in 
general. Massive carbonate veins are the major vein type for Unit IV and downhole to the upper and middle parts of Unit VII (Fig. F32C). In the upper sedimentary units of Hole U1373A (Units I and III), carbonate, minor brown clay, and green clay, as well as some sediment, are the most important vein infillings. From Unit IV to the bottom of this hole the abundance of green and black clay increases, as do Fe oxyhydroxides (Fig. F33). Many veins show a thin layer of clay at their margins and a later stage filling of carbonates (Fig. F32D), shown in XRD spectra as $\mathrm{Mg}$ calcite, saponite, bannisterite, and chalcopyrite for Sample 330-U1373A-7R-2, 141-142 cm (Fig. F24A). Another vein shows $\mathrm{Mg}$ calcite and aragonite (Sample 330-U1373A-10R-2, 108-110 cm; Fig. F24B). Zeolite is more common in the lowermost two lava flow Units VI and VII. In the lower part of Unit VII ( $60 \mathrm{mbsf}$ and below) cross-fibrous carbonate veins are the dominant vein type.

\section{Olivine alteration}

Most of the olivine observed in core samples or thin sections presents varying degrees of alteration, as discussed above. The only interval with significant amounts of fresh to moderately altered olivine is a Type 7 clast (see "Igneous petrology and volcanology" for further definition) in Section 330-U1373A1R-2 at 1.69-2.35 mbsf in Unit I (Fig. F20A, F20B) and a highly olivine-augite phyric massive basalt in Unit VI (Samples 330-U1373A-7R-2, 129-130 cm [Thin Section 90], and 7R-3, 109-111 cm [Thin Section 92]; Fig. F20C, F20D). A summary of olivine (and glass) preservation in thin section is given in Table T6.

Several types of olivine alteration were observed in Hole U1373A. From Units I through III, olivine is mainly altered to iddingsite and hematite (Figs. F19, F21A, F21B), with some occurrences of mixtures of Fe oxides, clay minerals (Fig. F21C), and carbonates. From Unit IV to the bottom of Hole U1373A, olivine is mainly altered into green and brown clay minerals (montmorillonite and bannisterite; Figs. F19, F22). Some olivine phenocrysts have thin rims of iddingsite, with carbonate and clay in the interior portions of the grains (Fig. F21A). Alteration was commonly initiated in cracks to form sawtooth patterns of green clay, followed by a colorless mineral in the central portion of the veins. This mineral could be a later infilling of chrysotile (Fig. F20E, F20F).

\section{Glass and groundmass alteration}

Rocks from Hole U1373A have varying degrees of groundmass alteration in the basaltic rocks. Groundmass augite is always unaltered, plagioclase in some samples is altered to sericite, and olivine and glass are extensively altered. Groundmass glass in most of the thin sections is completely altered to clay minerals or palagonite. Nevertheless, slightly altered groundmass glass is present in thin sections from Sections 330-U1373A-1R-2, 1R-3, 7R-3, 7R-4, 9-1, 9R2, and 13R-1 (Table T6).

\section{Interpretation of alteration}

The abundant occurrence of smectite (saponite and nontronite), celadonite, Fe oxyhydroxides, and zeolites in Hole U1373A indicates low temperatures $\left(30^{\circ}-150^{\circ} \mathrm{C}\right)$ typical of the lowest stage of ocean crust alteration (Alt, 1995). The association of these secondary minerals suggests circulation of large volumes of oxidizing fluids in the lava pile. If interpretation of the XRD data is correct, chlorite appears in Units IV and VI, which would be interpreted as alteration at higher temperatures $\left(250^{\circ}-300^{\circ} \mathrm{C}\right)$. The abundance of sulfides (pyrite) in the lower part of Hole U1373A below $~ 45$ mbsf points to a change from oxidizing to reducing conditions consistent with the change of alteration zones at the same depth.

From the bottom to the top of Hole U1373A we observed gray massive aphyric basalt (Unit VII) that experienced slight alteration. The presence of green clay after olivine indicates reducing conditions for these basalts and reflects a submarine environment. The upper portions of core with a variety of grayishbrown to reddish-brown colors are indicative of oxidizing conditions, as shown by the alteration of olivine to iddingsite. Vesicles and veins present more or less the same characteristics with depth for the upper Units I-VI (with the exception of Unit IV). We interpret these units to have been emplaced and weathered under subaerial conditions. Units V and VI are separated by a thin oxidized layer, likely representing an ancient weathering horizon.

\section{Structural geology}

At Site U1373 on the eastern side of Rigil Guyot, structures represent syn- to late- and postmagmatic features, comprising magmatic flow alignments/foliations, fractures, veins, vein networks, and geopetal structures (Fig. F34; Table T7). The characteristics, orientations, and distribution of these structures are described below.

Geopetal structures were observed at 2.9, 9.7-10.8, 16.5, 25.9, and 36.9 mbsf (Fig. F35). All geopetals have horizontal infilling, implying that this part of the seamount experienced little or no reorientation after these geopetals were filled. The paleomagnetic directions (see "Paleomagnetism") were therefore determined on lavas that are still in their in situ position. 
Fractures $(N=110)$ and veins and vein networks $(N=$ 290) are the dominant structural features at Site U1373 (Fig. F34). Both veins and fractures were found predominantly in the lava flows of Units IV and VII, with fewer fractures or veins in breccia or interbedded sediment (Figs. F36, F37). Rocks at Site U1373 host considerably more veins and fractures per meter than those at Site U1372, and hence this part of Rigil Guyot likely experienced more fluid flow than Site U1372 on Canopus Guyot. Fractures are especially abundant in the lowermost Unit VII, with as many as 11 fractures per meter (Figs. F36, F37), which is more than twice the density observed in other fractured rocks at Sites U1372 and U1373.

Unit VII also has moderate to strong magmatic foliation, which is visible in both hand specimen and in thin section. The magmatic foliation is defined by aligned plagioclase laths (Fig. F38). In contrast to Site U1372, elongated and aligned Fe-Ti oxides were not observed in the groundmass. Foliation directions within this unit vary from subhorizontal to subvertical, often over a scale of $1 \mathrm{~m}$ or less. These frequent direction changes in magmatic foliation are best explained by a sheet flow that experienced several horizontal injections of fresh lava, causing horizontal flow alignment, followed by flow inflation or vertical breakout events to produce the vertical mineral alignment. This explanation of repeated flow inflation is consistent with the thick nature of Unit VII (>22 m recovered) (Fig. F36). Repeated flow inflation events also explain why this unit is relatively homogeneous and fine grained. If this unit instead represented a dike or ponded lava flow, such a thick unit would be expected to have a coarser grain size toward the center of the unit, which was not observed. In certain sections, especially Sections 330-U1373A$13 \mathrm{R}-1$ through $13 \mathrm{R}-4$, where flow alignment is particularly strong, fractures and veins have similar orientations to the flow texture. If the pieces could be corrected for core barrel rotation, these flow textures would yield the direction of the lava flows, which would be useful for volcanological reconstruction of this site.

Dip and dip direction were measured for 143 veins, 57 fractures, and 24 magmatic foliations (Fig. F39). Fractures are dominantly steeply dipping, with a pronounced maximum of $70^{\circ}-75^{\circ}$. There is also a conjugate set of fractures with shallower dips of $10^{\circ}-15^{\circ}$. Most vein dips are between $10^{\circ}$ and $40^{\circ}$, with a maximum at $\sim 25^{\circ}$, although several veins have steeper dips of $50^{\circ}-75^{\circ}$ (maximum at $55^{\circ}$ ) and probably represent conjugate structures. The veins are likely healed fractures.

At Site U1373, single veins (and individual veinlets within vein networks) have an average width of
$1 \mathrm{~mm}$ and a maximum width of $9 \mathrm{~mm}$. These widths are similar to those observed at Site U1372 and are relatively narrow compared to those at other submarine volcanic environments, such as the Emperor Seamounts ( 2-4 mm; Tarduno, Duncan, Scholl, et al., 2002). The comparatively narrow vein widths indicate that the volume of fluid passing through the rocks of Site U1373 might have been lower than in Emperor Seamount drill sites.

\section{Summary}

Structures found at Site U1373 are veins, vein networks, fractures, magmatic foliations, and geopetals. The location, size, and orientation of these features were measured where possible. The occurrence of horizontally oriented geopetal structures indicate that these units are in situ and have not been tilted since deposition. A large portion of veins and fractures occur in hard lava flows of the lower units, with relatively few in breccia or volcaniclastic sediments. There is a bimodal distribution of dip angles for veins and fractures, with maxima of $70^{\circ}$ and $15^{\circ}$ for fractures and $25^{\circ}$ and $55^{\circ}$ for veins. Unit VII has moderate to strong flow textures that change direction from subhorizontal to subvertical, often within $1 \mathrm{~m}$ intervals. These changes in flow textures in Unit VII are best explained by a single thick lava flow unit that underwent several episodes of lava injection and flow inflation.

\section{Geochemistry \\ Igneous rocks}

Ten samples of igneous rocks from Hole U1373A were analyzed for concentrations of major elements and several trace elements (Table T8) by inductively coupled plasma-atomic emission spectroscopy (see "Geochemistry" in the "Methods" chapter [Expedition 330 Scientists, 2012a] for information on analytical procedures, instrumentation, and data quality). Two samples were from clasts of lava within the Unit I conglomerate. Eight were from lava flows of Units II, IV, VI, and VII. Of these samples, four were from the $>22 \mathrm{~m}$ thick massive basalt flow of Unit VII.

As at Site U1372, total weight percentages for the major element oxides vary significantly, from 97.35 to $103.92 \mathrm{wt} \%$. Possible reasons for this behavior are discussed in "Geochemistry" in the "Methods" chapter (Expedition 330 Scientists, 2012a). In order to better compare results with one another and with data from the literature, we normalized raw major element values to $100 \mathrm{wt} \%$ totals. The normalized values are presented below the raw data in Table T8 and are used in the figures and in the discussion below. 
Weight loss on ignition (LOI), an indicator of the overall level of alteration, varies between 0.9 and 2.4 $\mathrm{wt} \%$ for all but one sample. Values for unaltered basalt are usually $<1$ wt\% (e.g., Rhodes, 1996). The LOI values thus indicate that these samples are only moderately altered as a group, consistent with their petrography (see "Alteration petrology" and "Igneous petrology and volcanology"). The exception is Sample 330-U1373A-2R-3 (Piece 4B, 135-137 cm) from Unit II, which has an LOI value of $7.2 \mathrm{wt} \%$. As at Site U1372, the main effect of alteration on the measured group of elements appears to be on $\mathrm{K}_{2} \mathrm{O}$, but the effect appears to be very significant only for the high-LOI sample, which also has the highest $\mathrm{K}_{2} \mathrm{O}$ content (2.67 wt $\%$ ). The other samples have $\mathrm{K}_{2} \mathrm{O}$ between 0.44 and $1.36 \mathrm{wt} \%$, and for them no significant correlation is present between $\mathrm{K}_{2} \mathrm{O}$ and LOI. Rather, $\mathrm{K}_{2} \mathrm{O}$ in these samples correlates positively with the other minor elements $\mathrm{Na}_{2} \mathrm{O}, \mathrm{TiO}_{2}$, and $\mathrm{P}_{2} \mathrm{O}_{5}$ $\left(r^{2}\right.$ varies between 0.58 and 0.67$)$.

In a total alkalis $\left(\mathrm{Na}_{2} \mathrm{O}+\mathrm{K}_{2} \mathrm{O}\right)$ vs. $\mathrm{SiO}_{2}$ diagram (Fig. F40), data for all but two Site U1373 samples fall in the field of basalt and overlap considerably with Site U1372. One Site U1373 data point lies (barely) within the field of basanite and tephrite. This data point is for the highly altered sample from Unit II whose $\mathrm{K}_{2} \mathrm{O}$ content, in particular, appears to have been elevated significantly by alteration, as noted above. The other data point outside the basalt field is for Unit IV Sample 330-U1373A-7R-2 (Piece 7B, 125$127 \mathrm{~cm}$ ) and lies within the field of picro-basalt. This sample is one of three Site U1373 basalts that have high $\mathrm{MgO}$ contents (10.50-13.46 wt\% vs. 4.89-6.62 $\mathrm{wt} \%$ for the other samples). All three of these basalts appear to contain excess olivine and augite (see below). The effect of olivine addition is to move data points in Figure $\mathrm{F} 40$ to lower $\mathrm{SiO}_{2}$ and lower $\mathrm{Na}_{2} \mathrm{O}+$ $\mathrm{K}_{2} \mathrm{O}$ values (olivine accommodates virtually no $\mathrm{Na}_{2} \mathrm{O}$ or $\mathrm{K}_{2} \mathrm{O}$ in its crystal lattice, whereas the $\mathrm{SiO}_{2}$ content of olivine varies with forsterite content but is typically relatively low at $\sim 40 \mathrm{wt} \%$ in moderately evolved basalts). This olivine addition effect indeed is observed because points for all three high- $\mathrm{MgO}$ samples fall at the lower left corner of the Site U1373 data distribution in the figure. Values for one high$\mathrm{MgO}$ sample (Unit I clast Sample 330-U1373A-1R-2 [Piece 2, 121-123 cm]) lie slightly below the line dividing alkalic and tholeiitic rocks of Hawaii. Like several samples from Site U1372, it appears to be a transitional basalt. Depending on the amount and composition of excess olivine in this sample, however, the liquid composition may have been somewhat more alkalic than suggested by the position of the bulk rock's data point in the figure. The other Site U1373 rocks originated from alkalic basalt mag- mas. Depending on the amount and composition of excess olivine in the two high-MgO Unit IV samples, their liquids may have been more alkalic than indicated by their data points in the figure.

The Site U1373 basalts are also similar to those of Site U1372 in other major element characteristics and in trace element characteristics. For example, the Site U1373 data largely overlap the Site U1372 array in diagrams of $\mathrm{MgO}$ vs. $\mathrm{Al}_{2} \mathrm{O}_{3}$ (Fig. F41A), $\mathrm{Na}_{2} \mathrm{O}$ (Fig. F41B), and $\mathrm{Fe}_{2} \mathrm{O}_{3}{ }^{\top}$ (total iron as $\mathrm{Fe}_{2} \mathrm{O}_{3}$ ), when excluding the highly altered Unit II sample on the basis of its high $7.2 \mathrm{wt} \% \mathrm{~K}_{2} \mathrm{O}$ abundance. The incompatible elements $\mathrm{TiO}_{2}, \mathrm{P}_{2} \mathrm{O}_{5}, \mathrm{Y}$, and $\mathrm{Zr}$ also define closely similar trends to those of the Site U1372 basalts (e.g., Fig. F42A, F42B). Likewise, the $\mathrm{Zr} / \mathrm{Ti}$ ratio (Fig. F43D) is within the same restricted range as that found for Site U1372 (average $=0.012 \pm 0.001$ in each case). The same is true of $\mathrm{Zr} / \mathrm{Y}$ (average $=7.8 \pm$ 0.9 at Site U1373 vs. $8.0 \pm 0.9$ at Site U1372). As at Site $\mathrm{U} 1372$, the $\mathrm{MgO}$ vs. $\mathrm{Al}_{2} \mathrm{O}_{3}$ array indicates the importance of olivine control on magmatic compositions at Site U1373 and that plagioclase played a rather small role, consistent with the relative scarcity of plagioclase phenocrysts in the rocks (see "Igneous petrology and volcanology"). The three high-MgO Site U1373 samples are all highly olivine-augitephyric, and their high $\mathrm{MgO}$ and $\mathrm{Ni}$ (277-381 ppm; Fig. F43B) contents appear to be a result of the presence of excess olivine phenocrysts, as is also the case for their high-MgO counterparts at Site U1372. Indeed, clear petrographic evidence of olivine addition is seen in the strain-banded olivine observed in the high-MgO Unit I clast from which Sample 330U1373A-1R-2 (Piece 2, 121-123 cm) was taken (Fig. F13).

Despite their very considerable similarities, however, the Site U1373 basalts do differ somewhat from those of Site U1372. For example, $\mathrm{Mg}$ number $\left(\mathrm{Mg} \#=100 \times \mathrm{Mg}^{2+} /\left[\mathrm{Mg}^{2+}+\mathrm{Fe}^{2+}\right]\right.$, assuming $\mathrm{Fe}_{2} \mathrm{O}_{3} /$ $\mathrm{FeO}=0.15$ ) varies from 45.0 to 72.7 among the Site U1373 basalts (Fig. F43A). This range is substantial but smaller than that found at Site U1372 (34.973.5; see "Geochemistry" in the "Site U1372" chapter [Expedition 330 Scientists, 2012b]). More significantly, the three high-MgO Site $\mathrm{U} 1373$ basalts have somewhat higher $\mathrm{CaO}$ and $\mathrm{CaO} / \mathrm{Al}_{2} \mathrm{O}_{3}$ (Fig. F41C) for a given $\mathrm{MgO}$ value than do the high-MgO basalts of Site U1372. This characteristic suggests that in addition to excess olivine, excess augite phenocrysts are also present in these basalts, consistent with their highly olivine-augite-phyric nature (see "Igneous petrology and volcanology"). Scandium provides further support for excess augite in the high-MgO samples in that Sc contents do not decrease with increasing $\mathrm{MgO}$ at Site U1373 (note that Sc data were 
not obtained for Site U1372). Addition and/or removal of olivine alone produces a negative correlation between Sc and $\mathrm{MgO}$ because Sc is incompatible in olivine. In contrast, Sc is compatible in clinopyroxene (e.g., Bacon and Druitt, 1988), explaining the elevated (but constant) Sc in all the Site U1373 basalts.

Another difference between the basalts at Sites U1372 and U1373 is illustrated in Figure F42C and F42D. Whereas most of the Site U1373 samples are very similar to those of Site U1372 in Ba and Sr, just as they are in $\mathrm{P}_{2} \mathrm{O}_{5}, \mathrm{Zr}, \mathrm{TiO}_{2}$, and $\mathrm{Y}$, the two high$\mathrm{MgO}$ basalts from Unit IV (Samples 330-U1373A7R-2 [Piece 7B, 125-127 cm] and 7R-3 [Piece 6B, 106$108 \mathrm{~cm}]$ ) have distinctly high $\mathrm{Sr}$ and $\mathrm{Ba}$ concentrations relative to their $\mathrm{TiO}_{2}$ contents. The introduction of calcium carbonate to a rock during alteration can raise $\mathrm{Sr}$ and $\mathrm{Ba}$ levels substantially, and carbonate veins were observed in Unit IV (see "Alteration petrology"). However, the samples taken for chemical analysis were from locations well removed from any veins. Furthermore, $\mathrm{CaCO}_{3}$ contains $\sim 44 \mathrm{wt} \%$ $\mathrm{CO}_{2}$, so basalts containing even small amounts of carbonate are characterized by elevated LOI values. Yet, the LOI values of the two Unit IV samples (1.9 and $2.3 \mathrm{wt} \%$ ) are not particularly high. We infer that these two samples may represent a slightly different magma type than that represented by Site U1372 and other Site U1373 basalts.

The four samples analyzed from the thick lava flow of Unit VII are relatively homogeneous in most of their elemental characteristics (e.g., Fig. F43A, F43B, F43D). However, their $\mathrm{Fe}_{2} \mathrm{O}_{3}{ }^{\top}$ content varies significantly, from 11.44 to 13.69 wt\% (Fig. F43C). The highest concentration is in Sample 330-U1373A-9R-2 (Piece 5B, 115-118 cm) (44.46 mbsf, top depth), which is from a core interval characterized by a peak in magnetic susceptibility (see "Physical properties"). The lowest concentration is in Sample 9R-3 (Piece 1B, 41-43 cm) (45.17 mbsf, top depth) from a nearby interval of unusually low magnetic susceptibility. The differences in $\mathrm{Fe}_{2} \mathrm{O}_{3}{ }^{\top}$ content are consistent with differences in the proportion of opaque minerals observed in these two intervals (see thin section descriptions for Samples 330-U1373A-9R-2, 113-115 cm [Thin Section 101], and 9R-3, 39-41 cm [Thin Section 102]).

\section{Carbon, organic carbon, nitrogen, and carbonate}

No samples from Site U1373 were analyzed for carbonate, total carbon, total organic carbon, or total nitrogen content.

\section{Physical properties}

Characterization of physical properties was conducted for Hole U1373A. Measurements included gamma ray attenuation (GRA) bulk density, wholeround and point magnetic susceptibility, laser height, and color reflectance. Whole-round core sections longer than $50 \mathrm{~cm}$ (42 of 44 available sections) were also run through the Natural Gamma Radiation Logger (NGRL). Discrete measurements included 12 thermal conductivity measurements at representative locations along the core and compressional wave ( $P$-wave) velocity and moisture and density measurements on 33 discrete oriented rock cubes. Most of these discrete samples were also used for paleomagnetic measurements of alternating-field demagnetization (see "Paleomagnetism"). Following the core depth below seafloor Method A (CSF-A) depth scale convention, data from cores with $>100 \%$ recovery (e.g., Cores 330-U1373A-7R and 8R) are shown as overlapping in figures and tables. Generally, all physical property data sets are mutually consistent and show clear trends correlating with stratigraphic units based on petrographic descriptions (see "Igneous petrology and volcanology") and with alteration trends (see "Alteration petrology").

\section{Whole-Round Multisensor Logger measurements}

Throughout the lithified sediments and igneous basement of Site U1373, individual sections usually contain multiple discrete pieces, as is typical of hard rock coring. To remove Whole-Round Multisensor Logger (WRMSL) and Section Half Multisensor Logger (SHMSL) data that were affected by the gaps and edge effects from these discontinuities, we applied a data filtering and processing algorithm (see "Physical properties" in the "Methods" chapter [Expedition 330 Scientists, 2012a]). In this report we show only the filtered data; for raw data we refer the reader to the visual core descriptions (see "Core descriptions") and the Laboratory Information Management System (LIMS) database (iodp.tamu.edu/ tasapps/).

\section{Magnetic susceptibility}

Whole-round magnetic susceptibility measurements are shown in Figure F44. Magnetic susceptibility is sensitive to the mineralogical composition of the rock. In sedimentary stratigraphic Units I and III, magnetic susceptibility averages $1.25 \times 10^{-2} \mathrm{SI}$. Magnetic susceptibility increases to an average of $1.64 \times$ $10^{-2} \mathrm{SI}$ in the brecciated lava flows of Unit II, reflecting the greater percentage of mafic material in this 
unit. Units V and VI and the top of VII (lithologic Unit 14) are composed of lava flows with peperitic tops and have an average magnetic susceptibility of $1.53 \times 10^{-2}$ SI. This value falls between the average magnetic susceptibility values for conglomerate and the brecciated lavas, which is consistent with the mixing of soft sediment and basalt. This interval (35-50 mbsf) is characterized by a series of highs and lows in magnetic susceptibility. The peaks typically occur near the top of the flow, close to the peperitic boundary (Fig. F45), which may indicate a gradational variation in oxygen fugacity that affected which iron-bearing mineral formed.

For stratigraphic units dominated by continuous lava flows (Units IV and VII), significant variability exists within and between these units. For example, Unit IV has the lowest average magnetic susceptibility $\left(3.86 \times 10^{-3} \mathrm{SI}\right)$ at Site U1373, whereas the $22 \mathrm{~m}$ thick lava flow that dominates Unit VII has an average magnetic susceptibility of $1.97 \times 10^{-2} \mathrm{SI}$, a factor of five higher. There is also significant variability within Unit VII, including a short spatial wavelength high-amplitude peak at 44.5 mbsf (interval 330U1373A-9R-2, 110-120 cm), which is approximately $20-30 \mathrm{~cm}$ below the base of the peperitic flow top (Fig. F45). This variability appears to correspond with a thin interval of abnormally high magnetite content that again may be caused by variation in oxygen fugacity near the top of the flow (Fig. F46). Inductively coupled plasma-atomic emission spectroscopy Sample 330-U1373A-9R-2, 115-117 cm, taken from this interval, also contains $2 \mathrm{wt} \%$ more iron than Sample 9R-3, 41-43 cm, taken in the interval of low magnetic susceptibility immediately below the peak (Table T8). There are several more gradual oscillations in Cores $11 \mathrm{R}$ and $12 \mathrm{R}$ in this stratigraphic unit. These changes may reflect processes associated with repeated injections of material within this inflated flow sheet (see "Igneous petrology and volcanology").

\section{Gamma ray attenuation bulk density}

The results of GRA-derived bulk density are shown in Figure F47. A correction factor of 1.138 was applied to all cores to account for the smaller diameter $(58 \mathrm{~mm})$ of hard rock cores (see "Physical properties" in the "Methods" chapter [Expedition 330 Scientists, 2012a]). Values of $<1.00 \mathrm{~g} / \mathrm{cm}^{3}$ were attributed to empty portions of core liner and were removed. Bulk density values range from 1.12 to $3.06 \mathrm{~g} / \mathrm{cm}^{3}$, with an average of $2.52 \mathrm{~g} / \mathrm{cm}^{3}$. The densities of sediments (Units I and III), brecciated lava flows (Unit II), and peperitic lava flows (Units V, VI, and top of VII) are very similar, averaging 2.34, 2.36, and $2.29 \mathrm{~g} / \mathrm{cm}^{3}$, respectively. The massive basalts in Units IV and VII have a much higher average density of $2.74 \mathrm{~g} / \mathrm{cm}^{3}$.

\section{Natural Gamma Radiation Logger}

Natural gamma radiation (NGR) measurements reflect the amount of uranium, thorium, and potassium present in the rock. Results from the NGRL are shown in Figure F48. NGR ranges from 5.28 to 33.75 counts per second (cps), with an average of 17.62 cps. Brecciated and peperitic lavas (Unit II and Units V, VI, and top of VII, respectively) generally have higher NGR values, with averages of 23.21 and 20.11 cps, respectively, which may represent increased alteration in these units. A strong uphole increase in NGR was seen from 20 to 12 mbsf. This increase most likely represents an uphole-increasing trend in alteration to minerals richer in $\mathrm{U}, \mathrm{Th}$, and $\mathrm{K}$. A high weight loss on ignition value obtained from Sample 330-U1373A-2R-3, 135-137 cm (13.6 mbsf), by geochemical analysis suggests this region contains significant alteration to clay, which provides some support for this interpretation (see "Geochemistry"). Another possible explanation could be an enriched component in the brecciated lava flow, seen first in fragments that reached the site before the actual flow and were incorporated into the conglomerate at the top of Unit III, immediately below the flow itself.

\section{Section Half Multisensor Logger measurements}

\section{Color reflectance spectrometry}

Color reflectance spectrometry results are summarized in Figure F49. The $L^{*}$ (lightness) of the recovered core averages 37.6. $\mathrm{L}^{*}$ is generally uniform throughout the hole, but two short intervals of lower $\mathrm{L}^{*}$ occur at 10.25-10.75 mbsf and 14.75-15.75 mbsf, corresponding to intervals with a visibly smaller proportion of white calcite cement.

Figure F49 also shows values of $\mathrm{a}^{*}$ and $\mathrm{b}^{*}$, which correspond to redness (positive) versus greenness (negative) and yellowness (positive) versus blueness (negative), respectively. The strongly red spectrum in Units I-III and VI correlates well with observations of red and brown alteration, including alteration of olivine to iddingsite (Figs. F19, F28). Positive $b^{*}$ values, corresponding to a more yellow spectrum, were observed predominantly in Units I, II, V, and VI and correlate well with the occurrence of brown alteration (Fig. F28). Trends in $b^{*}$ do not correlate with those in $a^{*}$ (e.g., $b^{*}$ increases with depth in Unit II, whereas $a^{*}$ is nearly constant, and $b^{*}$ subtly decreases with depth in Units $\mathrm{V}$ and VI, whereas $\mathrm{a}^{*}$ shows the opposite trend). 
A slightly greener spectrum was observed in Units IV and $\mathrm{V}$ and in two intervals in Unit VII (45-50 mbsf and 55-65 mbsf), which correlates well with observations of green clay in veins and vesicles, moderately altered olivines, and olivines altered to green clay minerals (Figs. F19, F29, F33).

\section{Point magnetic susceptibility}

Point magnetic susceptibility results are shown in Figure F44 with whole-round magnetic susceptibility data. Both data sets agree well and show clear distinctions between brecciated lava flows, sediments, and peperitic units. Average point magnetic susceptibility values are $9.02 \times 10^{-3}$ SI for sediment (Units I and III), $1.27 \times 10^{-2} \mathrm{SI}$ for brecciated lava flows (Unit II), and $1.04 \times 10^{-2} \mathrm{SI}$ for peperitic units (Units $\mathrm{V}$ and VI and top of Unit VII). Unit IV and the inflated sheet flow in Unit VII again show distinct magnetic susceptibility profiles, with averages of $2.49 \times 10^{-3} \mathrm{SI}$ and $1.46 \times 10^{-2} \mathrm{SI}$, respectively.

\section{Moisture and density}

Results of bulk density, dry density, grain density, void ratio, water content, and porosity measurements on discrete samples are listed in Table T9. Bulk density ranges from 2.23 to $3.10 \mathrm{~g} / \mathrm{cm}^{3}$, with an average of $2.60 \mathrm{~g} / \mathrm{cm}^{3}$. Porosity ranges from $1.13 \%$ to $36.94 \%$, with an average of $16.2 \%$. As illustrated in Figure F50, a strongly linear negative correlation between bulk density and porosity was observed. Bulk density measurements from discrete samples also agree well with GRA-derived bulk density measurements, as shown by Figure F51. The near one-to-one linear relationship between the two supports our 1.138 volume correction factor for GRA-derived bulk density. GRA-derived bulk density values may be affected by the presence of fractures and cracks in the whole-round cores, slight variations in core radius (approximately $\pm 1-2 \mathrm{~mm}$ ), and distortions of the core's cylindrical shape near the ends of pieces or from large voids. These factors can cause overestimates of the total volume used in GRA-derived bulk density calculations even after the correction factor is applied, thus explaining why some GRA-derived bulk densities remain slightly lower than the corresponding results from discrete samples.

Figure F47 shows the variation of bulk density with depth, based on both discrete samples and GRA-derived bulk density, and further illustrates the strong correlation between the two. A high average bulk density $\left(2.77 \mathrm{~g} / \mathrm{cm}^{3}\right)$ characterizes the massive basalt flows of Units IV and VII, whereas the brecciated lavas of Unit II and the peperitic lavas that are predominant in Units $\mathrm{V}$ and $\mathrm{VI}$ and the top of Unit
VII have lower average bulk densities of 2.41 and $2.36 \mathrm{~g} / \mathrm{cm}^{3}$, respectively.

The percent porosity measured in the discrete samples also changes distinctly with depth (Fig. F52). These changes correlate with stratigraphic units and changes in other physical properties, particularly bulk density. In general, porosity is low (average = $7.7 \%$ ) in Unit IV and the lower $22 \mathrm{~m}$ of Unit VII. In contrast, high porosity characterizes the brecciated lava flows of Unit II (25.3\%) and the peperites of Units V and VI and the top of Unit VII (24.2\%). Porosity and bulk density in the conglomerate (Units I and III) are highly dependent on the proportion of matrix to clast in the sample and are thus highly variable, with ranges of $1.1 \%-31.9 \%$ and $2.34-3.11$ $\mathrm{g} / \mathrm{cm}^{3}$, respectively.

\section{Compressional wave ( $P$-wave) velocity}

The measured $P$-wave velocity of discrete samples shows a strong linear relationship with bulk density (Fig. F53). Downhole variations in discrete $P$-wave velocity are shown in Figure F47 and Table T10. $P$-wave velocities range from 3.14 to $7.05 \mathrm{~km} / \mathrm{s}$, with an average of $4.84 \mathrm{~km} / \mathrm{s}$. In Units I and III, $P$-wave velocities are widely scattered, ranging from 3.24 to $6.98 \mathrm{~km} / \mathrm{s}$ reflecting lithologic variations between the matrix and different basaltic clast types. Among the igneous units, the massive basalts of Unit IV and the lower $22 \mathrm{~m}$ of Unit VII have a high average velocity of $5.90 \mathrm{~km} / \mathrm{s}$. The brecciated Unit II and peperitic rocks that characterize Units V and VI and the top of Unit VII have average velocities of 3.83 and $4.01 \mathrm{~km} / \mathrm{s}$, respectively, reflecting the higher porosity and higher percentage of sedimentary material in these rocks. Most samples show no statistically significant anisotropy; of those that do, the anisotropy has no consistent relationship with depth or lithology.

\section{Thermal conductivity}

Thermal conductivity is largely a function of the porosity and mineralogical composition of the rock. Thermal conductivity values for Site U1373 range from 1.18 to $2.29 \mathrm{~W} /(\mathrm{m} \cdot \mathrm{K})$, with an average of 1.54 $\mathrm{W} /(\mathrm{m} \cdot \mathrm{K})$. Downhole variations in thermal conductivity are shown in Figure F52 and listed in Table T11. Although there is no clear trend in the downhole variations, Figure F54 shows a strong linear relationship between thermal conductivity and GRAderived bulk density, which suggests that the variation in thermal conductivity is primarily due to variation in porosity rather than mineralogical composition and that the scatter visible in Figure F52 reflects the heterogeneity of the rocks recovered. Unit VII is 
the most homogeneous unit; however, it still contains vesicular intervals. The thermal conductivity measurement at 58 mbsf was taken in such an interval, explaining its lower thermal conductivity. Sample 330-U1373A-12R-2, 61-63 cm, was taken in the same vesicular interval and, as expected, has a higher porosity, lower density, and lower $P$-wave velocity than the more characteristic samples taken from the unit.

\section{Paleomagnetism}

The natural remanent magnetization (NRM) intensity of samples from Hole U1373A ranges from 0.08 to $20.46 \mathrm{~A} / \mathrm{m}$ (median $=2.99 \mathrm{~A} / \mathrm{m}$ ), with the highest values exclusively associated with Unit VII at the base of the hole. Relatively well defined principal component directions with misfit values of $\leq 3.42$ were obtained for 576 intervals from archive-half core measurements (for pieces longer than $9 \mathrm{~cm}$ ). These directions are generally consistent with stepwise alternating-field (AF) and thermal demagnetization results from 34 discrete samples. This agreement suggests that it may be possible to obtain reliable inclinations for 10 in situ cooling units.

\section{Archive-half core remanent magnetization data}

The remanent magnetization of archive halves from Cores 330-U1373A-1R through 13R was measured at $2 \mathrm{~cm}$ intervals using the cryogenic magnetometer. All data acquired within $4.5 \mathrm{~cm}$ of either piece end were filtered out prior to further processing, and thus only data from pieces longer than $9 \mathrm{~cm}$ were considered (see "Paleomagnetism" in the "Methods" chapter [Expedition 330 Scientists, 2012a]).

The downhole variation of NRM intensity and magnetic susceptibility is shown in Figure F55B and F55C. Samples from Unit VII have the highest NRM intensities (median $=6.22 \mathrm{~A} / \mathrm{m}$ ). There is no evidence for any systematic trend in NRM intensity with lithology or depth. For example, median NRM intensities are comparable in the peperitic lavas of Unit VI (median $=2.0 \mathrm{~A} / \mathrm{m}$ ) and the sedimentary units (Unit I, median $=2.2 \mathrm{~A} / \mathrm{m}$; Unit III, median = $1.1 \mathrm{~A} / \mathrm{m})$. The pronounced variations in susceptibility in Unit VI and the uppermost part of Unit VII presumably reflect variations in magnetic mineral content in the individual peperitic lava flows. However, there is no clear pattern of susceptibility or remanent intensity variations relative to any flow margins in Unit VI.
Archive halves were progressively AF demagnetized, and principal component analysis (PCA) directions were calculated automatically over a range of demagnetization levels, where the lowest misfit value was used to identify the most reliable linear segment (see "Paleomagnetism" in the "Methods" chapter [Expedition 330 Scientists, 2012a]). The resulting characteristic remanent magnetization (ChRM) directions and intensities (1436 intervals) are shown in Figure F55D and F55B, respectively, where more robust PCA picks with misfits of $\leq 3.42$ (40\% of all data; $n=$ 576) are emphasized by black and dark red circles.

The archive-half AF demagnetization data reveal a pronounced difference in magnetic stability for the lowermost thick lava flow in Unit VII (lithologic Unit 15). The average median destructive field $\left(\mathrm{MDF}^{\prime}\right.$, the alternating field required to reduce the vector difference sum to half its initial value) in lithologic Unit 15 is $11.6 \mathrm{mT}$ (Fig. F55E). The low coercivity of the remanent magnetization in this unit is also evident in the nearly one order-of-magnitude difference in the NRM and PCA intensities (note the difference between purple and black circles in Fig. F55B). Interestingly, the inclination of the low-coercivity (0-15 $\mathrm{mT})$ component of magnetization throughout Hole U1373A is broadly distributed but with a mean centered near $15^{\circ}$. This shallow-inclination low-coercivity component is therefore unlikely to be related to drilling, which normally results in a subvertical low-coercivity component of magnetization. Although radially oriented magnetization components (related to drilling or sawing) have been noted during some previous hard rock legs (e.g., Fig. f116 in Dick, Natland, Miller, et al., 1999), we see no compelling evidence for such radial magnetizations.

The mean $\mathrm{MDF}^{\prime}$ value of lithologic Units $6-13$ is 34.9 $\pm 14.7 \mathrm{mT}$, and the more stable nature of the remanent magnetization is evident in the AF demagnetization data (Fig. F56). In these units, most intervals display relatively simple behavior during demagnetization, and in general the automatically picked PCA direction spans the highest $\mathrm{AF}$ demagnetization range.

The resulting ChRM inclinations from Units I-III are scattered, whereas those from Units IV-VII have consistent moderate to steep negative inclinations indicative of normal polarity in the Southern Hemisphere (Fig. F55D). Lithologic Units 6-15 from the lower half of the hole (33.91-66.17 mbsf) were all assigned the highest in situ confidence index (ISCI $=3$; see "Igneous petrology and volcanology" in the "Methods" chapter [Expedition 330 Scientists, 2012a]), whereas units in the upper part of the hole, 
including the two sedimentary horizons (Units I and III), were classified as units that cannot have retained their original orientation since cooling $($ ISCI $=\mathrm{NA}$ ). Paleomagnetic data support this division on the basis of the increased spread in inclinations determined for the uppermost units compared to lithologic Units 6-15.

\section{Discrete sample remanent magnetization data}

Remanent magnetization data were obtained for 34 discrete samples from Hole U1373A (Table T12), including basalt flows and basalt clasts from the upper portion of the hole. NRM intensities for these samples range from 0.34 to $13.5 \mathrm{~A} / \mathrm{m}$, and the mean Königsberger ratio (Qn) is 20.9 , indicating that the contribution of the induced component to the magnetization is minimal (Fig. F57).

Twenty-three discrete samples were subjected to stepwise AF demagnetization, and the remaining samples were thermally demagnetized. Samples from the volcanic breccia of Unit II may exhibit different ChRM directions over small spatial scales and may also have multicomponent remanent magnetization (Fig. F58B), presumably reflecting variations in the remanence direction of individual clasts. Larger clasts in the volcanic breccia, as well as in the sedimentary conglomerate (Fig. F58A, F58C), generally have nearly univectorial magnetization following removal of a lower stability component (by 5-15 mT or $400^{\circ} \mathrm{C}$ ). Most samples from basalt flows or peperitic flows display relatively simple demagnetization behavior (Fig. F58D-F58F). As noted above, samples from lithologic Unit 15 have low-stability magnetization, with MDF values of $<10 \mathrm{mT}$ and much of the magnetization removed by $200^{\circ}-300^{\circ} \mathrm{C}$ (Fig. F58G).

\section{Anisotropy of magnetic susceptibility}

The anisotropy of magnetic susceptibility (AMS) was measured for all discrete samples (Table T13). The average degree of anisotropy ( $\mathrm{P}^{\prime}$; Jelinek, 1981) is 1.04 , and the anisotropy tensor shapes range from strongly oblate to strongly prolate. The lava flows from Units IV and VII are the most anisotropic ( $\mathrm{P}^{\prime}$ values as high as 1.11), and most have prolate magnetic fabrics. The maximum eigenvectors from Unit VII samples are all subhorizontal, whereas those from the lavas in Unit IV are more variable. Magnetic fabrics and structural observations agree in some cases (e.g., both show shallow, eastwarddipping foliations in Core 330-U1373A-11R). However, the AMS data show few near-vertical foliations in lithologic Unit 15, in contrast to structural observations (see "Structural geology"). Shore-based studies may provide a more systematic comparison of AMS and magmatic fabrics.

\section{Discussion}

Archive-half and discrete sample inclination data from Hole U1373A are summarized in Figure F59 and Table T14. Ten in situ lava flows (lithologic Units 6-15) were identified with the highest ISCI (ISCI $=3$; see "Igneous petrology and volcanology"). Discrete samples were obtained from only 9 of 10 in situ lava flows. The archive-half measurements provide the most comprehensive view of inclination variations in these flows, and we calculated average inclinations using inclination-only statistics (Arason and Levi, 2010) for each lithologic unit in two ways (Fig. F59C-F59E) (see "Paleomagnetism" in the "Methods" chapter [Expedition 330 Scientists, 2012a]).

For lithologic Units $6-15$, the various inclination estimates from the archive halves agree well (Fig. F59). The piece-average inclinations (Fig. F59D) from lithologic Unit 15 show considerable scatter, resulting in part from the fact that the ChRM direction represents only a small fraction of the initial remanence and from the tendency for spurious anhysteretic remanent magnetization to be acquired during AF demagnetization at high fields in these low-coercivity samples. The archive-half data sets also agree well with results from discrete sample demagnetization (Fig. F59F). The discrete sample inclinations show a significant serially correlated variation from $\sim 38$ to 45 mbsf. These variations are paralleled by changes in the piece-average directions.

\section{Summary}

The range of inclinations recorded in Hole U1373A is broader and generally shallower than that found in Hole U1372A, as illustrated in archive-half data at both the $2 \mathrm{~cm}$ interval and piece-average levels (Fig. F60C, F60D). The more dispersed inclination distribution from Hole U1373A relative to that from Hole $\mathrm{U} 1372 \mathrm{~A}$ is a result of the significant number of positive inclinations recorded in the uppermost units comprising sediment and breccia lithologies (Units I-III) and the increased scatter in lithologic Unit 15, which has lower magnetic stability (see earlier discussion). The more reliable (ISCI $=3$ ) discrete data have only negative inclinations (Fig. F60B). Although these 25 inclinations are more clustered, the inclination-only mean of $-51.9^{\circ} \pm 6^{\circ}\left(\alpha_{95}\right)$ is nonetheless consistently shallower than that in Hole U1372A (Fig. F60E). If the proportionally larger number of discrete measurements corresponding to lithologic Unit 15 ( $n=11)$ are first averaged using inclination-only statistics to give a flow mean, then the subsequent inclination-only mean of the nine distinct flow units with good paleomagnetic data becomes $-55.2^{\circ} \pm 10.6^{\circ}\left(\alpha_{95}\right)$. However, the particularly 
small number of lava flows recovered at this site may not allow averaging of paleosecular variation and therefore limits any paleolatitude determination.

\section{Microbiology}

The goals of microbiology sampling at Site U1373 were to collect samples for shore-based cell counts, molecular biological analyses, and $\delta^{34} S$ and $\delta^{13} \mathrm{C}$ stable isotope analyses; to inoculate media for cultivation of subseafloor microbes; and to set up stable isotope addition bioassays whereby the rate of incorporation of compounds labeled with ${ }^{14} \mathrm{C}$ and ${ }^{34} \mathrm{~S}$ stable isotopes can be measured. Such bioassays then allow for calculation of metabolic rates of subseafloor microbes. Five whole-round samples (5-10 $\mathrm{cm}$ long) were collected for microbiological analysis (Figs. F61, F62). The samples were sedimentary conglomerate (one), aphyric basalt breccia (one), and aphyric basalt lava flows (three). In the thick lava flow at the bottom of Hole U1373A, samples with visible veins were preferably taken for microbiological analyses. Four of the five samples were preserved for shore-based DNA analysis, cell counting, and $\delta^{34} \mathrm{~S}$ and $\delta^{13} \mathrm{C}$ analyses. Sample 330-U1373A-10R-2, 114$123 \mathrm{~cm}$, contained no veins or features that would allow fluid flow, and after several failed attempts to crack open the core with a hammer and chisel, it was determined that this rather massive basalt was likely to have little or no microbial life. Therefore, a subsample was taken for cell counts only. Sample 330U1373A-2R-1, 120-133 cm, was used to inoculate culturing experiments with six different types of cultivation media; Sample 330-U1373A-11R-2, 122-133 $\mathrm{cm}$, was collected for shipboard analysis of contamination via fluorescent microsphere analysis; and Sample 330-U1373A-13R-3, 118-128 cm, was used to set up a stable isotope addition bioassay.

\section{Cell counts}

Performing shipboard cell counts on rock samples is difficult to nearly impossible because of the combination of autofluorescence from rock particles and the difficulty of focusing using a 100x objective paired with a $10 \times$ eyepiece $(1000 \times$ total magnification) on a moving ship. Therefore, cell counts were not attempted on samples from Site U1373.

\section{Culturing experiments}

Twelve vials were inoculated for culturing experiments with media targeting autotrophic sulfur oxidizers, heterotrophic sulfur oxidizers, autotrophic iron oxidizers, autotrophic iron reducers, heterotrophic iron reducers, and nonspecific heterotrophs (for details on media recipes, see Table T14 in the "Methods" chapter [Expedition 330 Scientists, 2012a]). Media were monitored for oxygen levels with the redox dye resazurin. The addition of resazurin turns media saturated in oxygen blue and media with low oxygen levels pink; anoxic media remain clear. Several types of media that require anoxic conditions (for methanogens and sulfate reducers) remained pink (instead of clear) despite continued efforts to generate anoxic conditions, and therefore these were not used for Hole U1373A samples because the targeted microbes would be poisoned by the presence of oxygen. Some culture experiments for autotrophic and heterotrophic sulfur oxidizers and nonspecific heterotrophs appeared to show growth on the basis of turbidity, but this requires verification by shore-based research.

\section{Contamination testing}

Fluorescent microspheres were deployed during drilling for Core 330-U1373A-11R. As the core arrived on the rig floor, a core laboratory technician collected the drill fluid draining from the core liner with a beaker. Analysis of this drill fluid provides the concentration of microspheres delivered to a core. Unfortunately, during retrieval of Core 330-U1373A$11 \mathrm{R}$, there was difficulty removing the core catcher, and nearly all of the drill fluid was lost. Therefore, only a few milliliters of drill fluid was recovered.

Water samples for microsphere counts were also collected from each of the three separate sterile seawater rinses that every microbiology (MBIO) wholeround sample was subjected to before subsampling. For each wash, $100 \mathrm{~mL}$ of sterile seawater was used. After MBIO whole-round Sample 330-U1372A-11R-2, $122-133 \mathrm{~cm}$, was washed, four subsamples were taken during standard MBIO sampling for DNA and cell counts and were preserved in the same way as cell count samples. Two subsamples were taken from the outside portion of the whole-round sample and two were taken from the center. Following MBIO sterile processing, a $\sim 1 \mathrm{~cm}$ thick whole-round slab was cut from the remainder of the whole-round sample with the Feckler saw. This slab was divided into five sections (Fig. F63) with the Feckler saw for microsphere counting of specific zones. Subsamples from these sections were taken specifically from the middle of the sections (area shown between dashed lines in Fig. F63).

Shipboard counts of fluorescent microspheres revealed only one microsphere in the drill fluid and one microsphere in Section 1 of the slabbed whole round; all other observed microscope fields, including those from the three sterile seawater rinses, the five sections of cut rock, and the four rock samples collected during standard MBIO sampling, were de- 
void of microspheres. The general absence of any microspheres, especially in the drill fluid, indicates three possibilities. First, it is possible that the microspheres were not delivered or that they remained very near the spot of delivery. However, we can rule out a lack of delivery, because the broken bag from which the microspheres were deployed was recovered within the core liner (Fig. F63). Second, it is possible that the microspheres did not circulate sufficiently in the core. A third possibility, one that is more likely, is that because of the relative impermeability of the lava flow collected in Core 330U1373A-11R, the microspheres could not penetrate into the massive basalt and were flushed out of the core barrel as the core ascended the water column on the way to the rig floor. This indicates that the chance for microbial contamination in this core is low and that the MBIO samples collected were pristine.

\section{Stable isotope addition bioassays}

Sample 330-U1373A-13R-3, 118-128 cm, was used to initiate a stable isotope addition bioassay. The purpose of these experiments is to determine metabolic rates of microbes living in the subseafloor basement environment. Recent work has illustrated the presence of microbial cells in basement habitats (Cowen et al., 2003; Mason et al., 2010; Santelli et al., 2010; Orcutt et al., 2011), but there are as yet no physiological data or metabolic rate estimates available for these microbes. The stable isotope addition bioassays performed during Expedition 330 aimed to constrain the rates of carbon cycling in the basement rocks of the Louisville Seamounts.

Approximately $15 \mathrm{~cm}^{3}$ of rock was collected from veins in Section 330-U1373A-13R-3 and split into three separate $125 \mathrm{~mL}$ precombusted glass serum vials. To these vials, $100 \mathrm{~mL}$ of sterile seawater (SigmaAldrich; St. Louis, MO) modified with $50 \mu \mathrm{M}$ sodium nitrate, $3 \mu \mathrm{M}$ potassium phosphate, and $0.5 \mu \mathrm{M}$ ammonium chloride was added as base media. We herein refer to this as the basic seawater media. In each vial containing $\sim 5 \mathrm{~cm}^{3}$ of rocks and $100 \mathrm{~mL}$ of basic seawater media, $2.71 \mu \mathrm{M}{ }^{13} \mathrm{C}$-labeled sodium bicarbonate and $0.30 \mu \mathrm{M}{ }^{34} \mathrm{~S}$ elemental sulfur was added. The vials were then placed in a $4^{\circ} \mathrm{C}$ incubator in the dark. At time points of 2 weeks, 2 months, and 6 months, the incubation in one of these three vials will be terminated, and the rocks will be collected for onshore measurement of the incorporation of labeled bicarbonate and sulfur.

\section{References}

Alt, J.C., 1995. Subseafloor processes in mid-ocean ridge hydrothermal systems. In Humphris, S.E., Zierenberg,
R., Mullineaux, L., and Thomson, R. (Eds.), Seafloor Hydrothermal Systems: Physical, Chemical, Biological and Geological Interactions within Hydrothermal Systems. Geophys. Monogr., 91:85-114.

Arason, P., and Levi, S., 2010. Maximum likelihood solution for inclination-only data in paleomagnetism. Geophys. J. Int., 182(2):753-771. doi:10.1111/j.1365246X.2010.04671.X

Bach, W., Hegner, E., Erzinger, J., and Satir, M., 1994. Chemical and isotopic variations along the superfast spreading East Pacific Rise from 6 to $30^{\circ} \mathrm{S}$. Contrib. Mineral. Petrol., 116(4):365-380. doi:10.1007/BF00310905

Bacon, C.R., and Druitt, T.H., 1988. Compositional evolution of the zoned calcalkaline magma chamber of Mount Mazama, Crater Lake, Oregon. Contrib. Mineral. Petrol., 98(2):224-256. doi:10.1007/BF00402114

Beier, C., Vanderkluysen, L., Regelous, M., Mahoney, J.J., and Garbe-Schönberg, D., 2011. Lithospheric control on geochemical composition along the Louisville Seamount Chain. Geochem., Geophys., Geosyst., 12:Q0AM01. doi:10.1029/2011GC003690

Beu, A.G., and Raine, J.I., 2009. Revised descriptions of New Zealand Cenozoic Mollusca from Beu and Maxwell (1990). GNS Sci. Misc. Ser., 27. http://www.gns.cri.nz/ static/Mollusca/

Busby-Spera, C.J., and White, J.D.L., 1987. Variation in peperite textures associated with differing host-sediment properties. Bull. Volcanol., 49(6):765-776. doi:10.1007/BF01079827

Cheng, Q., Park, K.-H., Macdougal, J.D., Zindler, A., Lugmair, G.W., Hawkins, J., Lonsdale, P., and Staudigel, H., 1987. Isotopic evidence for a hot spot origin of the Louisville Seamount chain. In Keating, B.H., Fryer, P., Batiza, R., and Boehlert, G. (Eds.), Seamounts, Islands and Atolls. Geophys. Monogr., 43:283-296.

Clague, D.A., Moore, J.G., Dixon, J.E., and Friesen W.B., 1995. Petrology of submarine lavas from Kilauea's Puna Ridge, Hawaii. J. Petrol., 36(2):299-349.

Courtillot, V., Davaille, A., Besse, J., and Stock, J., 2003. Three distinct types of hotspots in Earth's mantle. Earth Planet. Sci. Lett., 205(3-4):295-308. doi:10.1016/S0012821X(02)01048-8

Cowen, J.P., Giovannoni, S.J., Kenig, F., Johnson, H.P., Butterfield, D., Rappé, M.S., Hutnak, M., and Lam, P., 2003. Fluids from aging ocean crust that support microbial life. Science, 299(5603):120-123. doi:10.1126/science. 1075653

Dick, H.J.B., Natland, J.H., Miller, D.J., et al., 1999. Proc. ODP, Init. Repts., 176: College Station, TX (Ocean Drilling Program). doi:10.2973/odp.proc.ir.176.1999

Duncan, R.A., Tarduno, J.A., and Scholl, D.W., 2006. Leg 197 synthesis: southward motion and geochemical variability of the Hawaiian hotspot. In Duncan, R.A., Tarduno, J.A., Davies, T.A., and Scholl, D.W. (Eds.), Proc. ODP, Sci. Results, 197: College Station, TX (Ocean Drilling Program), 1-39. doi:10.2973/ odp.proc.sr.197.001.2006

Expedition 330 Scientists, 2012a. Methods. In Koppers, A.A.P., Yamazaki, T., Geldmacher, J., and the Expedition 330 Scientists, Proc. IODP, 330: Tokyo (Integrated Ocean 
Drilling Program Management International, Inc.). doi:10.2204/iodp.proc.330.102.2012

Expedition 330 Scientists, 2012b. Site U1372. In Koppers, A.A.P., Yamazaki, T., Geldmacher, J., and the Expedition 330 Scientists, Proc. IODP, 330: Tokyo (Integrated Ocean Drilling Program Management International, Inc.). doi:10.2204/iodp.proc.330.103.2012

Fitton, J.G., and Godard, M., 2004. Origin and evolution of magmas on the Ontong Java Plateau. In Fitton, J.G., Mahoney, J.J., Wallace, P.J., and Saunders, A.D. (Eds.), Origin and Evolution of the Ontong Java Plateau. Geol. Soc. Spec. Publ., 229(1):151-178. doi:10.1144/

GSL.SP.2004.229.01.10

Flügel, E., 1982. Microfacies Analysis of Limestones: New York (Springer-Verlag).

Frey, F.A., Garcia, M.O., Wise, W.S., Kennedy, A., Gurriet, P., and Albarede, F., 1991. The evolution of Mauna Kea Volcano, Hawaii: petrogenesis of tholeiitic and alkalic basalts. J. Geophys. Res., [Solid Earth], 96(B9):1434714375. doi:10.1029/91JB00940

Frey, F.A., Wise, W.S., Garcia, M.O., West, H., Kwon, S.-T., and Kennedy, A., 1990. Evolution of Mauna Kea Volcano, Hawaii: petrologic and geochemical constraints on postshield volcanism. J. Geophys. Res., [Solid Earth], 95(B2):1271-1300. doi:10.1029/JB095iB02p01271

Garcia, M.O., Pietruszka, A.J., and Rhodes, J.M, 2003. A petrologic perspective of Kilauea Volcano's summit magma reservoir. J. Petrol., 44(12):2313-2339. doi:10.1093/petrology/egg079

Hawkins, J.W., Lonsdale, P., and Batiza, R., 1987. Petrologic evolution of the Louisville Seamount Chain. In Keating, B.H., Fryer, P., Batiza, R., and Boehlert, G.W. (Eds.), Seamounts, Islands, and Atolls. Geophys. Monogr., 43:235254.

Jelinek, V., 1981. Characterization of the magnetic fabric of rocks. Tectonophysics, 79(3-4):T63-T67. doi:10.1016/ 0040-1951(81)90110-4

Kokelaar, B.P., 1982. Fluidization of wet sediments during the emplacement and cooling of various igneous bodies. J. Geol. Soc. (London, U. K.), 139(1):21-33. doi:10.1144/gsjgs.139.1.0021

Koppers, A.A.P., Duncan, R.A., and Steinberger, B., 2004. Implications of a nonlinear ${ }^{40} \mathrm{Ar} /{ }^{39} \mathrm{Ar}$ age progression along the Louisville Seamount trail for models of fixed and moving hot spots. Geochem., Geophys., Geosyst., 5(6):Q06L02. doi:10.1029/2003GC000671

Koppers, A.A.P., Yamazaki, T., and Geldmacher, J., 2010. Louisville Seamount Trail: implications for geodynamic mantle flow models and the geochemical evolution of primary hotspots. IODP Sci. Prosp., 330. doi:10.2204/ iodp.sp.330.2010

Le Maitre, R.W., Bateman, P., Dudek, A., Keller, J., Lameyre, J., Le Bas, M.J., Sabine, P.A., Schmid, R., Sorensen, H., Streckeisen, A., Woolley, A.R., and Zanettin, B., 1989. A Classification of Igneous Rocks and Glossary of Terms: Oxford (Blackwell).

Lipman, P.W., Rhodes, J.M., and Dalrymple, G.B, 1990. The Ninole basalt-implications for the structural evolution of Mauna Loa Volcano, Hawaii. Bull. Volcanol., 53(1):1-19. doi:10.1007/BF00680316
Macdonald, G.A., 1968. Composition and origin of Hawaiian lavas. In Coats, R.R., Hay, R.L., and Anderson, C.A. (Eds.), Studies in Volcanology-A Memoir in Honor of Howel Williams. Mem.-Geol. Soc. Am., 116:477-522.

Macdonald, G.A., and Katsura, T., 1964. Chemical composition of Hawaiian lavas. J. Petrol., 5(1):82-133. http:// petrology.oxfordjournals.org/content/5/1/ 82.abstract

Mahoney, J.J., Sinton, J.M., Kurz, M.D., Macdougall, J.D., Spencer, K.J., and Lugmair, G.W., 1994. Isotope and trace element characteristics of a super-fast spreading ridge: East Pacific Rise $13-23^{\circ}$ S. Earth Planet. Sci. Lett., 121(1-2):173-193. doi:10.1016/ 0012-821X(94)90039-6

Mahoney, J.J., and Spencer, K.J., 1991. Isotopic evidence for the origin of the Manihiki and Ontong Java oceanic plateaus. Earth Planet. Sci. Lett., 104(2-4):196-210. doi:10.1016/0012-821X(91)90204-U

Mason, O.U., Nakagawa, T., Rosner, M., Van Nostrand, J.D., Zhou, J., Maruyama, A., Fisk, M.R., and Giovannoni, S.J., 2010. First investigation of the microbiology of the deepest layer of ocean crust. PLoS One, 5(11):e15399. doi:10.1371/journal.pone.0015399

Moore, J.G., and Clague, D.A., 1992. Volcano growth and evolution of the island of Hawaii. Geol. Soc. Am. Bull., 104(11):1471-1484. doi:10.1130/ 0016-7606(1992)104<1471:VGAEOT>2.3.CO;2

Orcutt, B.N., Bach, W., Becker, K., Fisher, A.T., Hentscher, M., Toner, B.M., Wheat, C.G., and Edwards, K.J., 2011. Colonization of subsurface microbial observatories deployed in young ocean crust. ISME J., 5:692-703. doi:10.1038/ismej.2010.157

Rhodes, J.M., 1996. Geochemical stratigraphy of lava flows sampled by the Hawaii Scientific Drilling Project. J. Geophys. Res., [Solid Earth], 101(B5):11729-11746. doi:10.1029/95JB03704

Rhodes, J.M., and Hart, S.R., 1995. Episodic trace element and isotopic variations in historical Mauna Loa lavas: implications for magma and plume dynamics. In Rhodes, J.M., and Lockwood, J.P. (Eds.), Mauna Loa Revealed: Structure, Composition, History, and Hazards. Geophys. Monogr., 92:263-288.

Richards, M.A., and Griffiths, R.W., 1989. Thermal entrainment by deflected mantle plumes. Nature (London, $U$. K.), 342(6252):900-902. doi:10.1038/342900a0

Riisager, P., Hall, S., Antretter, M., and Zhao, X., 2003. Paleomagnetic paleolatitude of Early Cretaceous Ontong Java Plateau basalts: implications for Pacific apparent and true polar wander. Earth Planet. Sci. Lett., 208(3-4):235-252. doi:10.1016/S0012821X(03)00046-3

Santelli, C.M., Banerjee, N., Bach, W., and Edwards, K.J., 2010. Tapping the subsurface ocean crust biosphere: low biomass and drilling-related contamination calls for improved quality controls. Geomicrobiol. J., 27(2):158169. doi:10.1080/01490450903456780

Sinton, J.M., Smaglik, S.M., Mahoney, J.J., and Macdonald, K.C., 1991. Magmatic processes at superfast spreading mid-ocean ridges: glass compositional variations along 
the East Pacific Rise $13^{\circ}-23^{\circ} \mathrm{S}$. J. Geophys. Res., [Solid Earth], 96:6133-6155. doi:10.1029/90JB02454

Skilling, I.P., White, J.D.L., and McPhie, J., 2002. Peperite: a review of magma-sediment mingling. J. Volcanol. Geotherm. Res., 114(1-2):1-17. doi:10.1016/S03770273(01)00278-5

Smith, W.H.F., and Sandwell, D.T., 1997. Global sea floor topography from satellite altimetry and ship depth soundings. Science, 277(5334):1956-1962. doi:10.1126/ science.277.5334.1956

Steinberger, B., 2002. Motion of the Easter hot spot relative to Hawaii and Louisville hot spots. Geochem., Geophys., Geosyst., 3(11):8503-8529. doi:10.1029/ 2002GC000334

Steinberger, B., and Antretter, M., 2006. Conduit diameter and buoyant rising speed of mantle plumes: implications for the motion of hot spots and shape of plume conduits. Geochem., Geophys., Geosyst., 7(11):Q11018Q11042. doi:10.1029/2006GC001409

Steinberger, B., and Calderwood, A., 2006. Models of largescale viscous flow in the Earth's mantle with constraints from mineral physics and surface observations. Geophys. J. Int., 167(3):1461-1481. doi:10.1111/j.1365246X.2006.03131.x

Steinberger, B., Sutherland, R., and O'Connell, R.J., 2004. Prediction of Emperor-Hawaii Seamount locations from a revised model of global plate motion and mantle flow. Nature (London, U. K.), 430(6996):167-173. doi:10.1038/nature02660

Stenzel, H.B., Moore, R.C., and Teichert, C. (Eds.), 1971. Treatise on Invertebrate Paleontology, Part N: Mollusca 6, Bivalvia (Oysters), Vol. 3: Kansas (GSA).

Tarduno, J.A., Duncan, R.A., Scholl, D.W., Cottrell, R.D., Steinberger, B., Thordarson, T., Kerr, B.C., Neal, C.R., Frey, F.A., Torii, M., and Carvallo, C., 2003. The
Emperor Seamounts: southward motion of the Hawaiian hotspot plume in Earth's mantle. Science, 301(5636):1064-1069. doi:10.1126/science.1086442

Tarduno, J.A., Duncan, R.A., Scholl, D.W., et al., 2002. Proc. ODP, Init. Repts., 197: College Station, TX (Ocean Drilling Program). doi:10.2973/odp.proc.ir.197.2002

Tejada, M.L.G., Mahoney, J.J., Duncan, R.A., and Hawkins, M.P., 1996. Age and geochemistry of basement and alkalic rocks of Malaita and Santa Isabel, Solomon Islands, southern margin of Ontong Java Plateau. J. Petrol., 37(2):361-394. doi:10.1093/petrology/37.2.361

Tejada, M.L.G., Mahoney, J.J., Neal, C.R., Duncan, R.A., and Petterson, M.G., 2002. Basement geochemistry and geochronology of central Malaita, Solomon Islands, with implications for the origin and evolution of the Ontong Java Plateau. J. Petrol., 43(3):449-484. doi:10.1093/petrology/43.3.449

Vanderkluysen, L., Mahoney, J.J., Koppers, A.A., and Lonsdale, P.F., 2007. Geochemical evolution of the Louisville Seamount Chain. Eos, Trans. Am. Geophys. Union, 88(52)(Suppl.):V42B-06. http://www.agu.org/meetings/fm07/waisfm07.html

Wessel, P., and Kroenke, L.W., 1997. A geometric technique for relocating hotspots and refining absolute plate motions. Nature (London, U. K.), 387(6631):365-369. doi:10.1038/387365a0

West, H.B., Garcia, M.O., Frey, F.A., and Kennedy, A., 1988. Nature and cause of compositional variation among the alkalic cap lavas of Mauna Kea Volcano, Hawaii. Contrib. Mineral. Petrol., 100(3):383-397. doi:10.1007/ BF00379747

Publication: 11 February 2012 MS 330-104 
Figure F1. Bathymetric map of the old end of the Louisville Seamount Trail in the southwest Pacific, showing the location of Osbourn Guyot, Site U1372 on Canopus Guyot, and Sites U1373 and U1374 on Rigil Guyot. GMT-generated bathymetric map is based on a combination of SIMRAD EM120 multibeam data collected during the AMAT02RR site survey expedition aboard the R/V Roger Revelle and the global predicted bathymetry (v8.2) from Smith and Sandwell (1997). The current motion of the Pacific plate is indicated with the black arrow. The map uses a linear projection (i.e., horizontal and vertical scales differ) based on WGS-84.

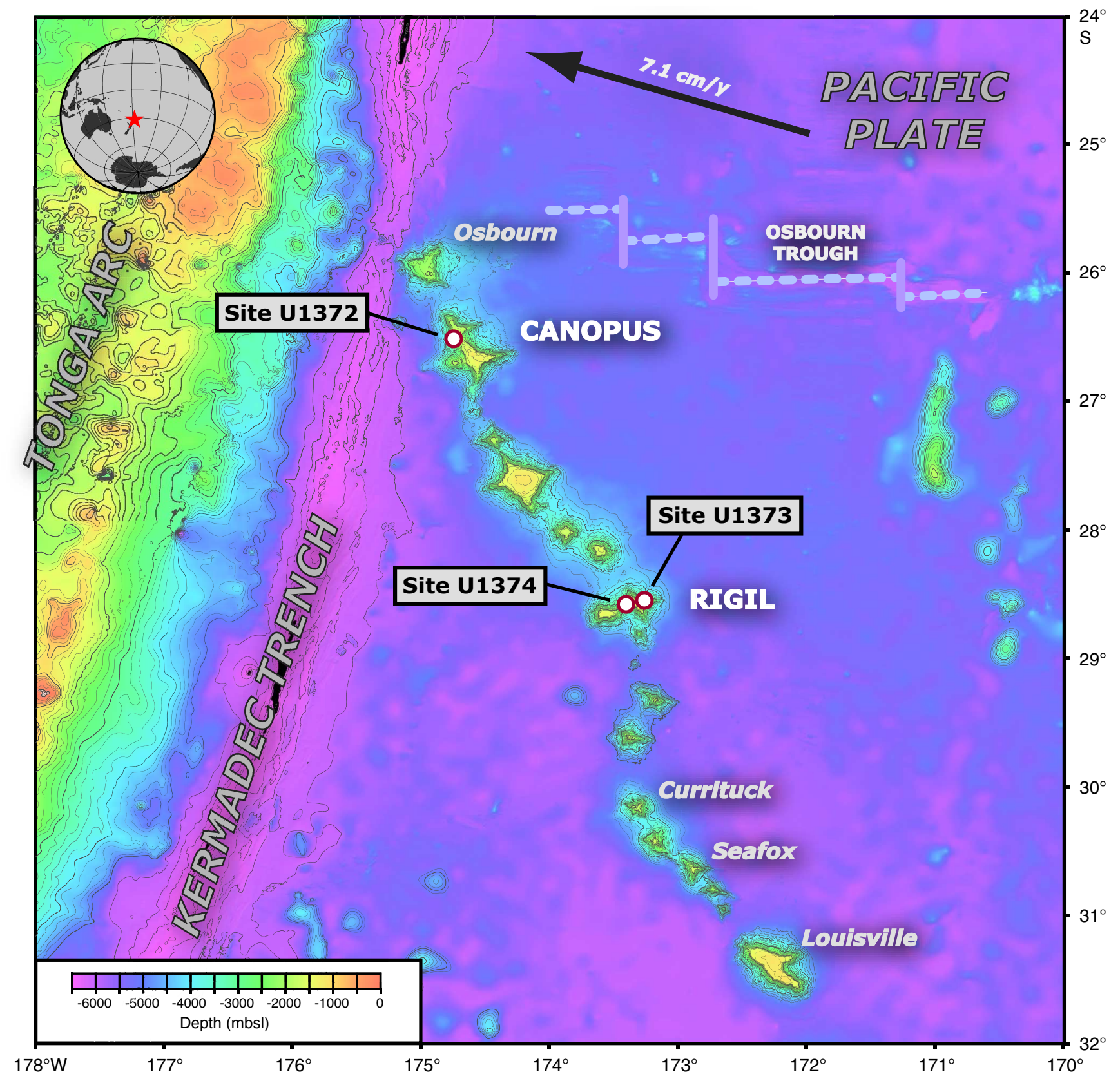


Figure F2. Detailed bathymetric map of Sites U1373 and U1374 on Rigil Guyot and three neighboring guyots or seamounts at $28.2^{\circ} \mathrm{S}, 28.7^{\circ} \mathrm{S}$, and $28.8^{\circ} \mathrm{S}$. GMT-generated bathymetric map is based on a combination of SIMRAD EM120 multibeam data collected during the AMAT02RR site survey expedition aboard the R/V Roger Revelle and is merged with global predicted bathymetry (v8.2) from Smith and Sandwell (1997). Dredge locations from previous cruises are indicated by open squares. Crossing multichannel seismic reflection lines collected during the AMAT02RR site survey are shown in blue (for details, see Koppers et al., 2010). Map uses a linear projection (i.e., horizontal and vertical scales differ) based on WGS-84.

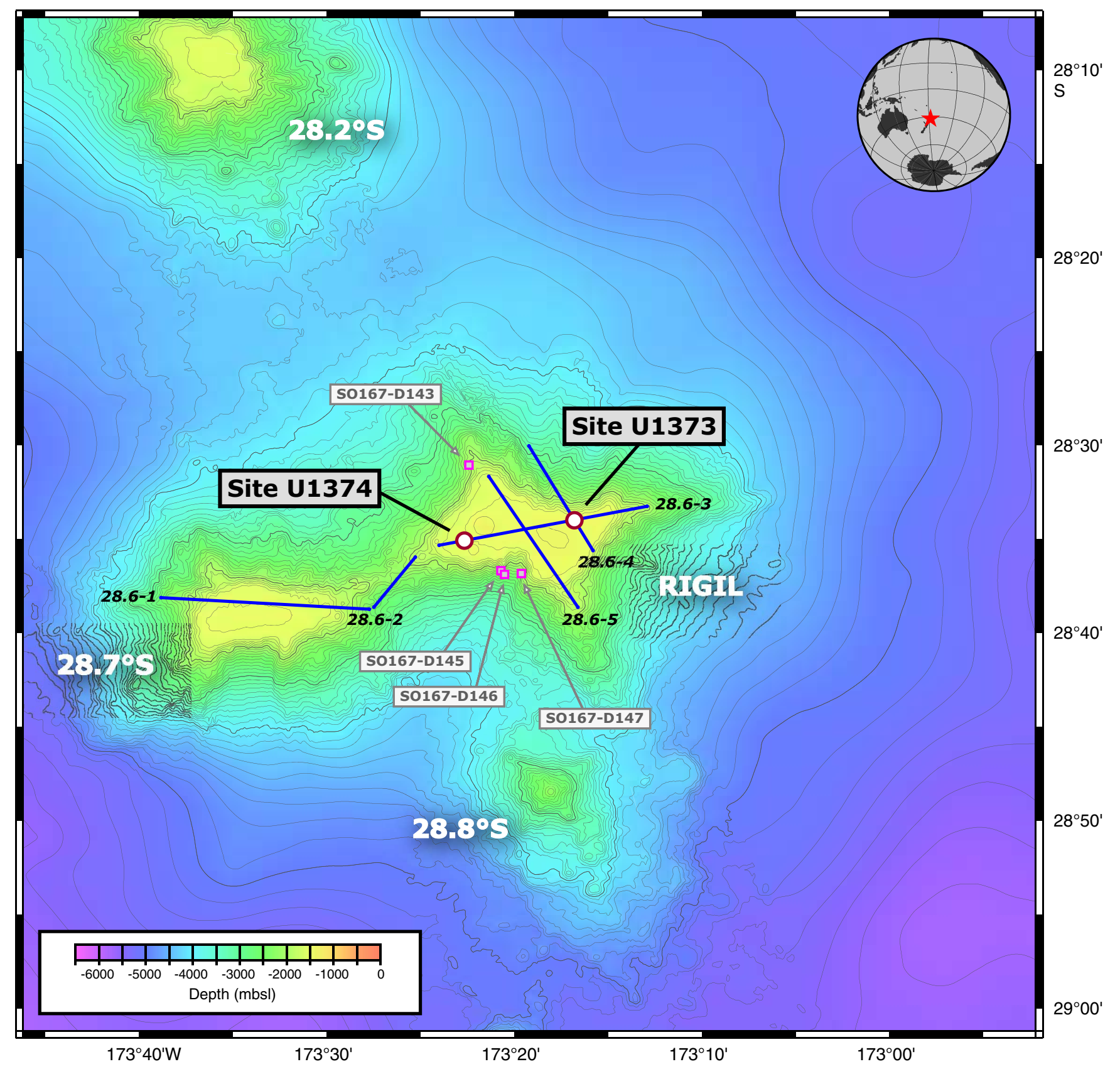


Figure F3. Operation time vs. penetration depth, Hole U1373A. Major operation milestones are labeled. Dashed line $=$ planned penetration, solid red line $=$ actual penetration. $\mathrm{RCB}=$ rotary core barrel, FFF $=$ free-fall funnel. Rot. $=$ rotation, $\mathrm{ROP}=$ rate of penetration .

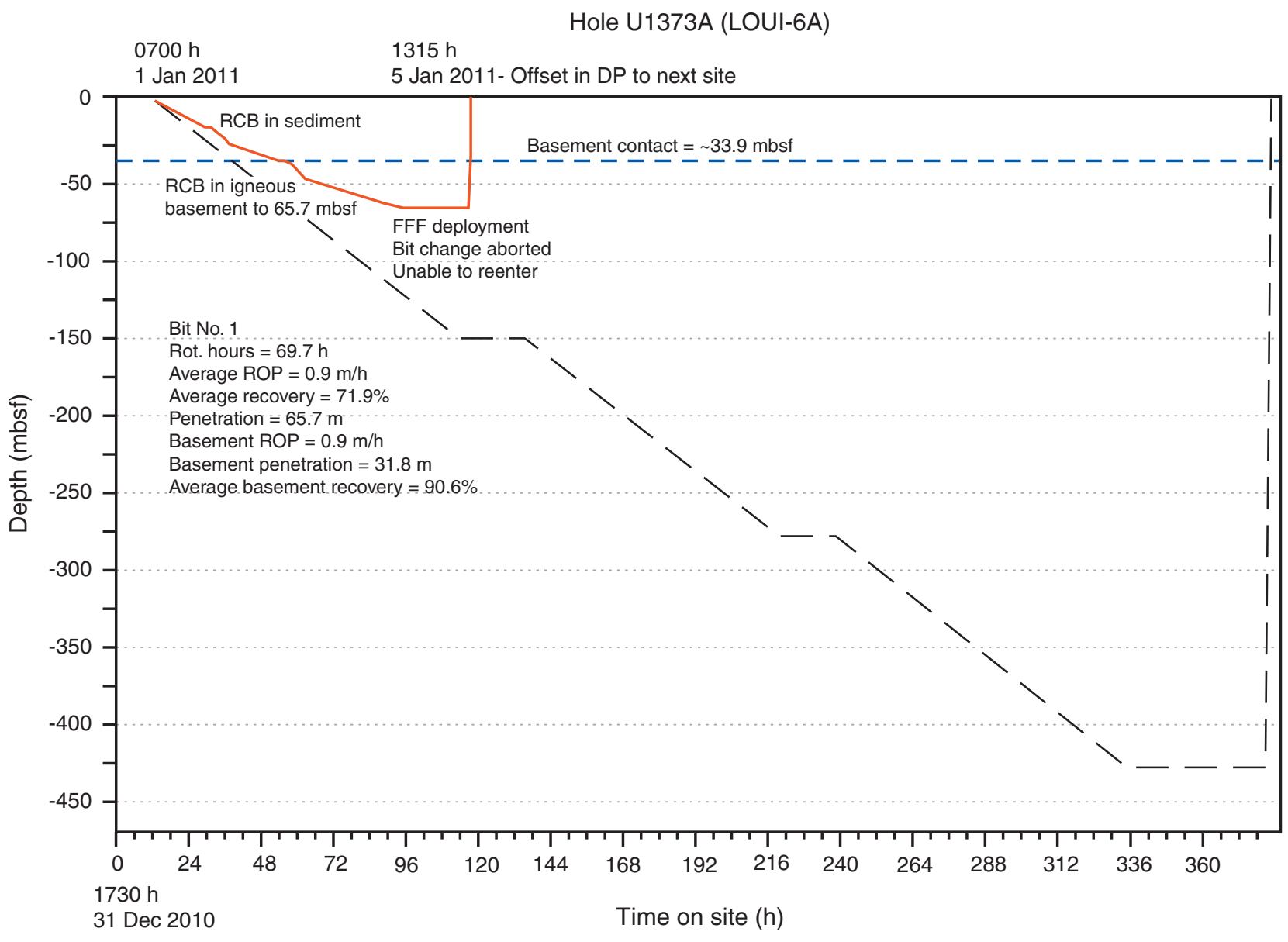


Figure F4. Stratigraphic summary of sedimentary sequences with selected lithologic parameters, Site U1373. See U1373A.XLS in SIZE in SEDIMENT in "Supplementary material" for estimates of grain size and roundness with depth (see also "Sedimentology" in the "Methods" chapter [Expedition 330 Scientists, 2012a]).

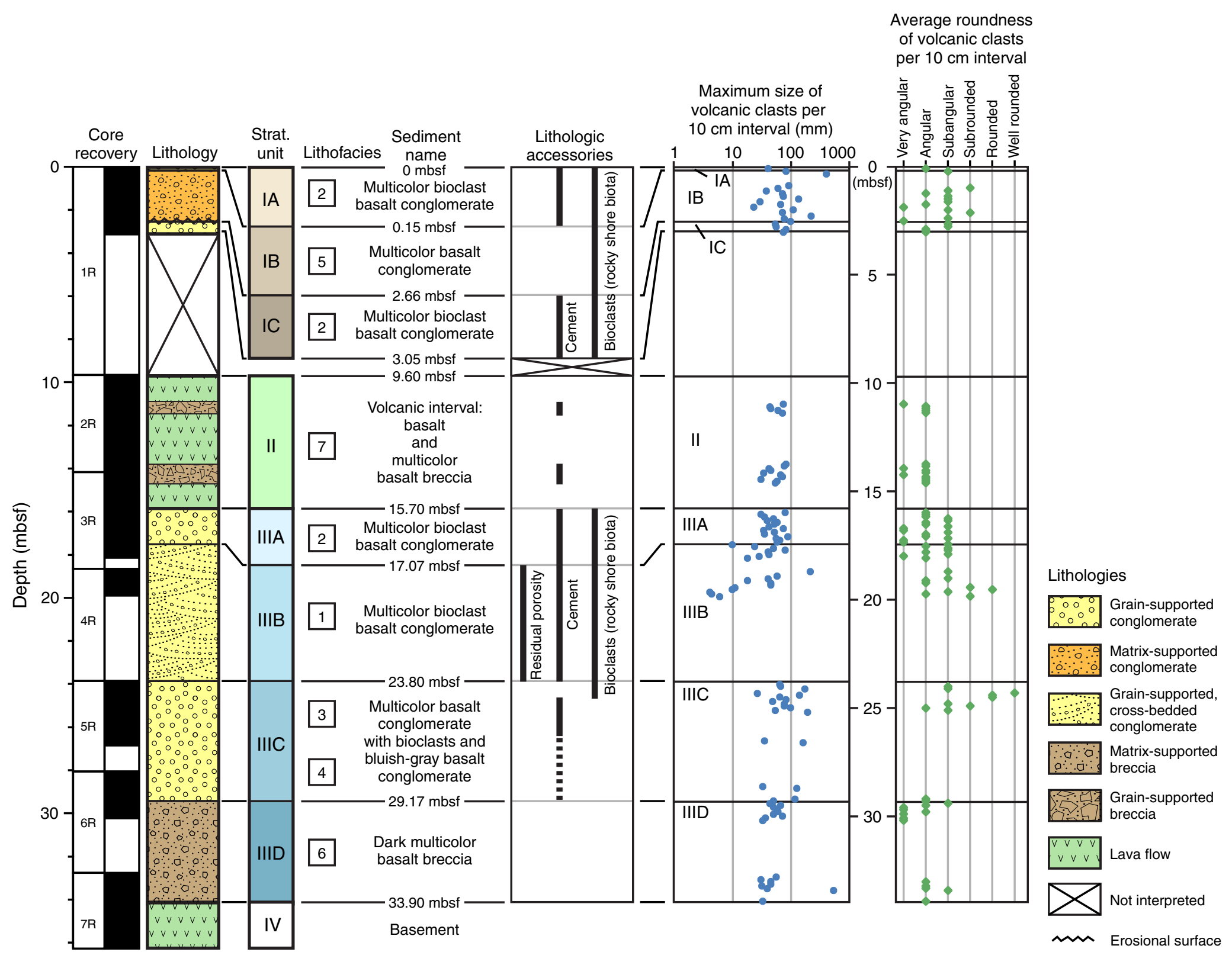


Figure F5. Close-up photographs of representative lithologies and lithofacies, Site U1373. A. Multicolor bioclast basalt conglomerate in Subunit IA, interpreted as deposited in a subtidal, shallow-marine environment (interval 330-U1373A-1R-1A, 0-15.5 cm). B. Multicolor basalt conglomerate with few bioclasts in Subunit IB (interval 330-U1373A-1R-2A, 16-56 cm). The brownish matrix reflects higher clay content relative to other lithofacies at Site U1373. Sediment is interpreted as mudflow deposited in a subtidal, shallow-marine environment. C. Multicolor bioclast basalt conglomerate in Subunit IC, interpreted as deposited in a subtidal to intertidal environment (interval 330-U1373A-1R-3A, 39-74 cm). D. Cemented multicolor basalt breccia in Unit II interbedded with lava flows and interpreted as a debris flow deposit emplaced in a submarine, shallowwater environment (interval 330-U1373A-2R-2A, 1-41 cm). (Continued on next page.)

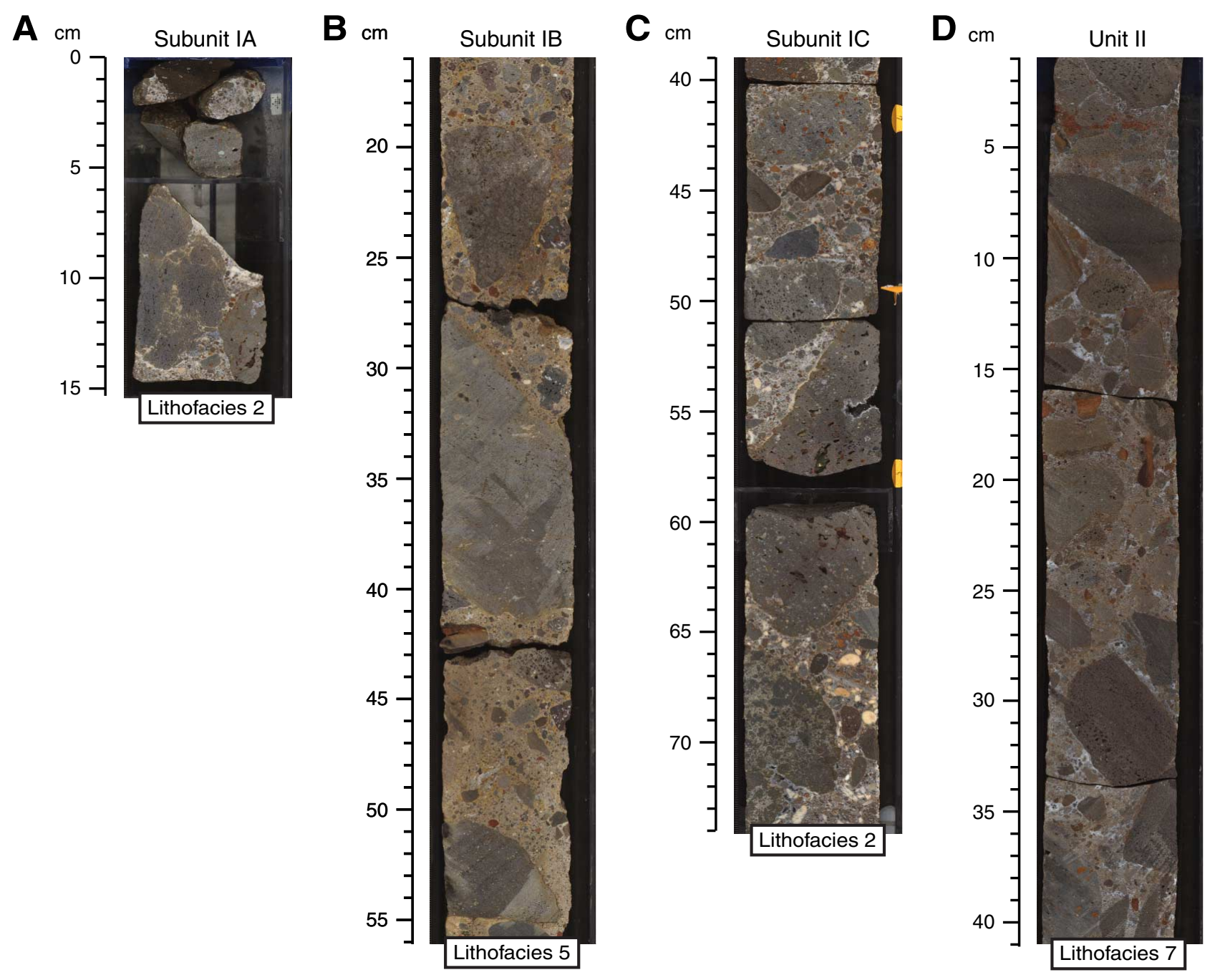


Figure F5 (continued). E. Multicolor bioclast basalt conglomerate in Subunit IIIA, interpreted as deposited in a subtidal, shallow-marine environment (interval 330-U1373A-3R-3A, 50-90 cm). F. Multicolor bioclast basalt conglomerate in Subunit IIIB, interpreted as deposited on a beach (interval 330-U1373A-3R-4A, 1-41 cm). Note the occurrence of distinct bedding and larger bioclasts. G. Multicolor basalt conglomerate with bioclasts in Subunit IIIC (Lithofacies 3; upper part) and bluish-gray basalt conglomerate essentially devoid of bioclasts (Lithofacies 4; lower part) (interval 330-U1373A-5R-1A, 29-69 cm). This assemblage of sediments is believed to reflect deposition in an intertidal environment. H. Dark multicolor basalt breccia devoid of bioclasts and carbonate in Subunit IIID, interpreted as a matrix-supported debris flow or possible lahar deposit (interval 330U1373A-7R-1A, 10-50 cm).
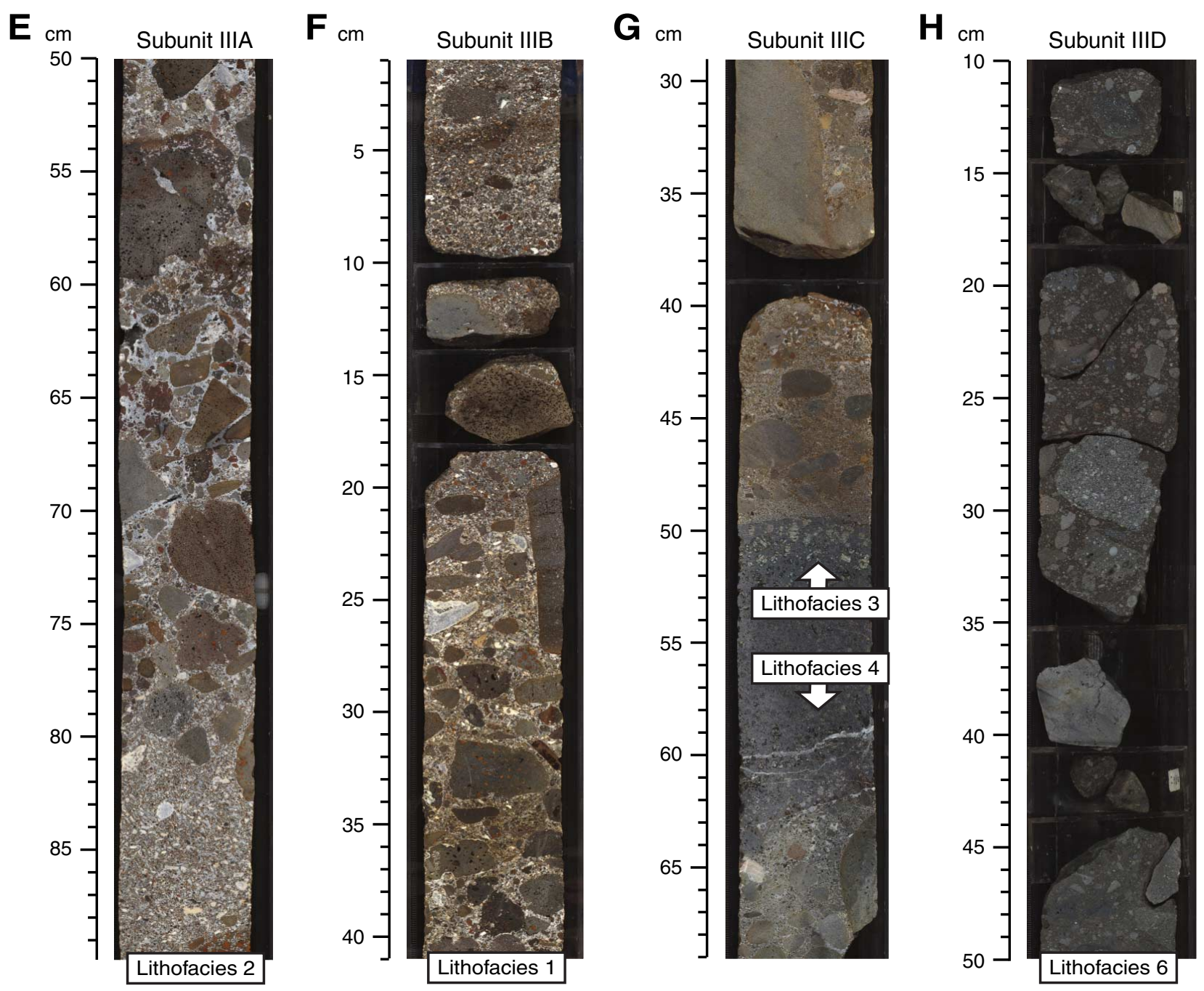
Figure F6. Single-polarized thin section photomicrographs displaying cement types and dissolution features, Site U1373. Orange arrows point toward top. Preliminary cement classification and interpretations of depositional environment are based on Flügel (1982). A. Grainstone in Subunit IIIA with (1) mold of dissolved shell fragment outlined by thin micrite envelope, (2) sparite cement partially filling mold, (3) remaining void, and (4) partly micritized cement, possibly resulting from biogenic activity (Sample 330-U1373A-3R-3, 86-89 cm; Thin Section 85). B. Grainstone in Subunit IIIB with (1) fibrous meniscus cement and (2) voids (Sample 330U1373A-4R-1, 72-74 cm; Thin Section 84). This cementation pattern supports an intertidal deposition environment. C. Grainstone in Subunit IIIC with (1) micrite (possibly meniscus cement), (2) dogtooth and granular cements, and (3) dissolved shell fragment (Sample 330-U1373A-5R-1, 33-36 cm; Thin Section 86). Meniscus and dogtooth cements indicate cementation in a vadose environment. D. Geopetal structure in Subunit IIIC (Sample 330-U1373A-5R-1, 33-36 cm; Thin Section 86). Mollusk shell includes (1) two layers of vadose silt, (2) dogtooth cement, and (3) granular cement. Vadose silt and dogtooth cement indicate cement precipitation in vadose environments. E. Grainstone in Subunit IIIC with (1) micrite with possible meniscus texture, (2) rim cement, and (3) granular cement, in order of generation (Sample 330-U1373A-5R-1, 101-104 cm; Thin Section 87). F. Grainstone with dripstone cement (Sample 330-U1373A-5R-1, 33-36 cm; Thin Section 86). Sparite cements concentrated on lower part of grains indicate precipitation in a vadose environment.

A

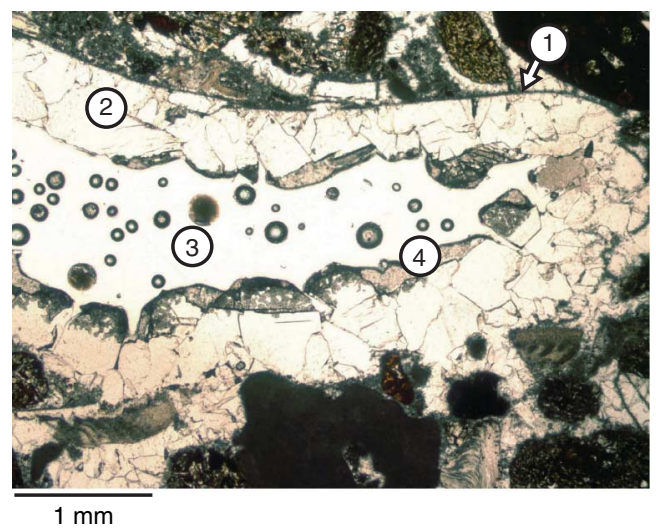

C

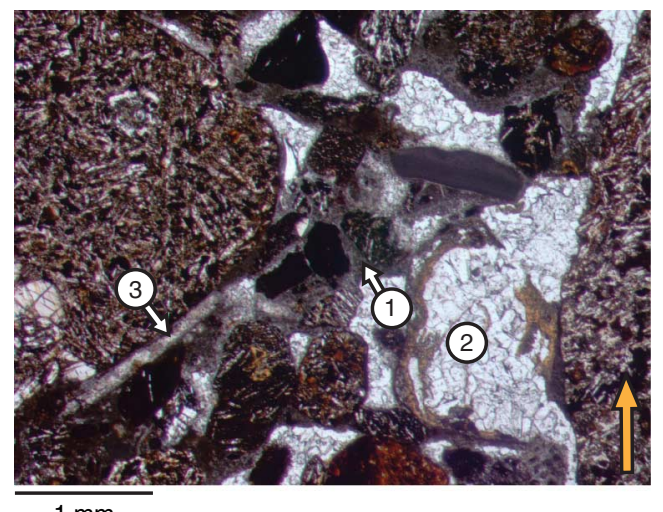

E

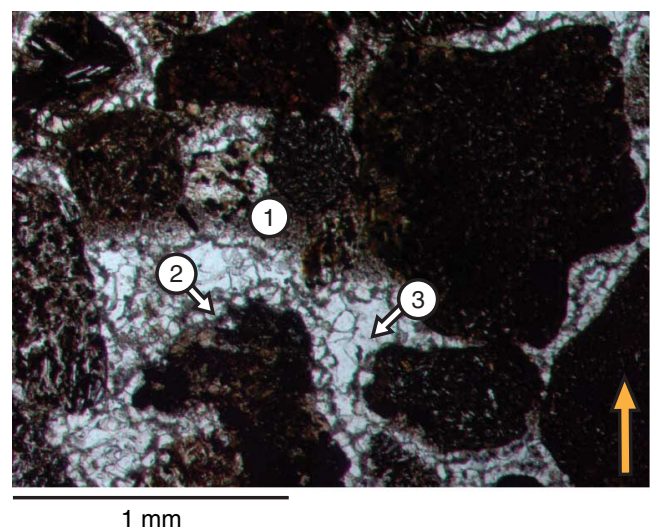

B

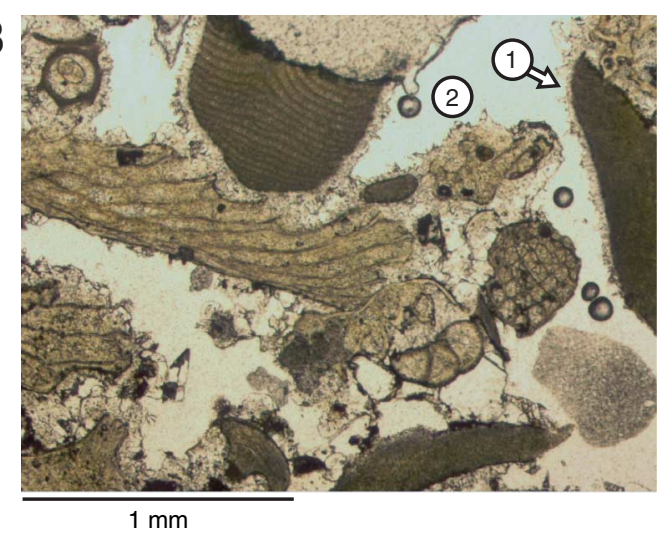

D

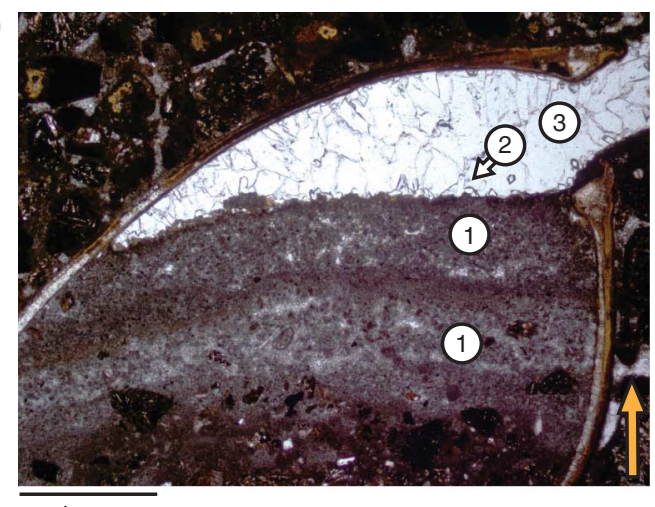

$1 \mathrm{~mm}$

$F$

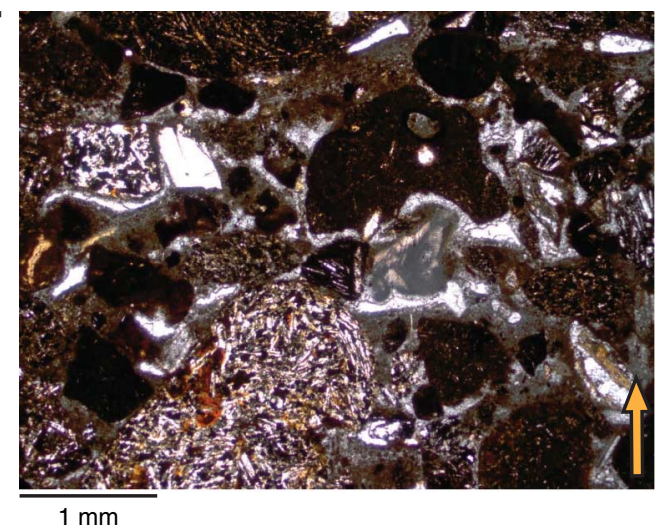


Figure F7. Thin section photomicrographs illustrating matrix-supported dark multicolor basalt breccia and fine-grained sediment in Subunit IIID and the underlying volcanic sequence. A, B. Dark multicolor basalt breccia (Sample 330-U1373A-6R-2, 39-43 cm; Thin Section 88) ([A] single polarized, [B] crossed polars). Matrix is composed of altered glass, and deposit is interpreted as a possible lahar deposit. C. Volcanic sandstone (Sample 330-U1373A-9R-2, 76-79 cm; Thin Section 100) (single polarized), displaying fine-grained fragments of altered volcanic glass coated by calcite cement. Sediment is interpreted as a possible lahar deposit partly mingled with a lava flow (see also "Igneous petrology and volcanology").

\section{A}

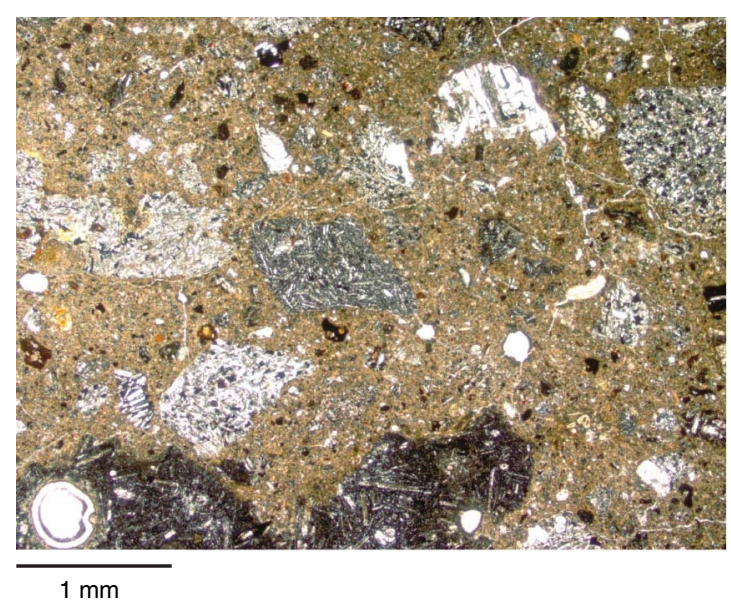

B
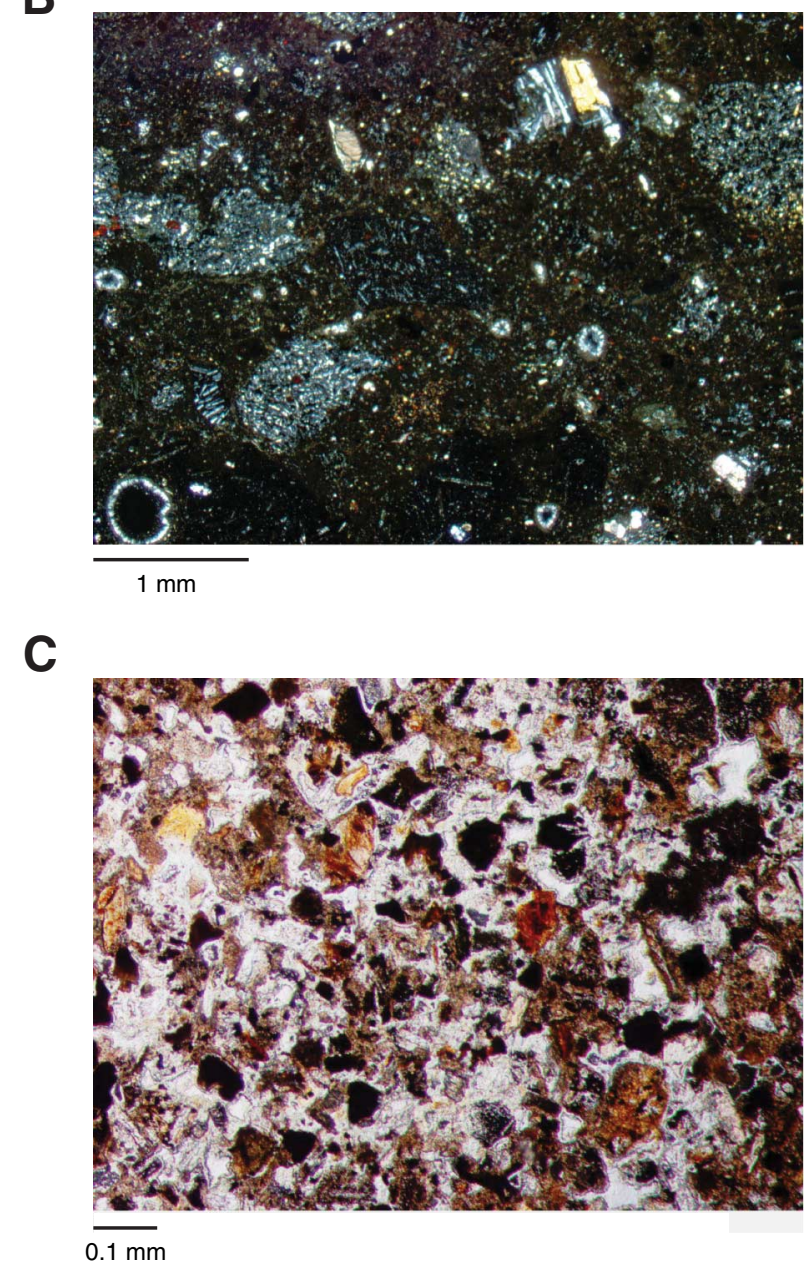
Figure F8. Calcareous nannofossil and planktonic foraminiferal biozonation, Hole U1373A. Gray shaded areas $=$ intervals barren of age-diagnostic calcareous microfossils. ${ }^{*}=$ based on macrofossil evidence. ${ }^{* *}=$ age of mostly unrecovered oozy sediment overlying Subunit IA. For legend of lithology patterns, see Figure F4.

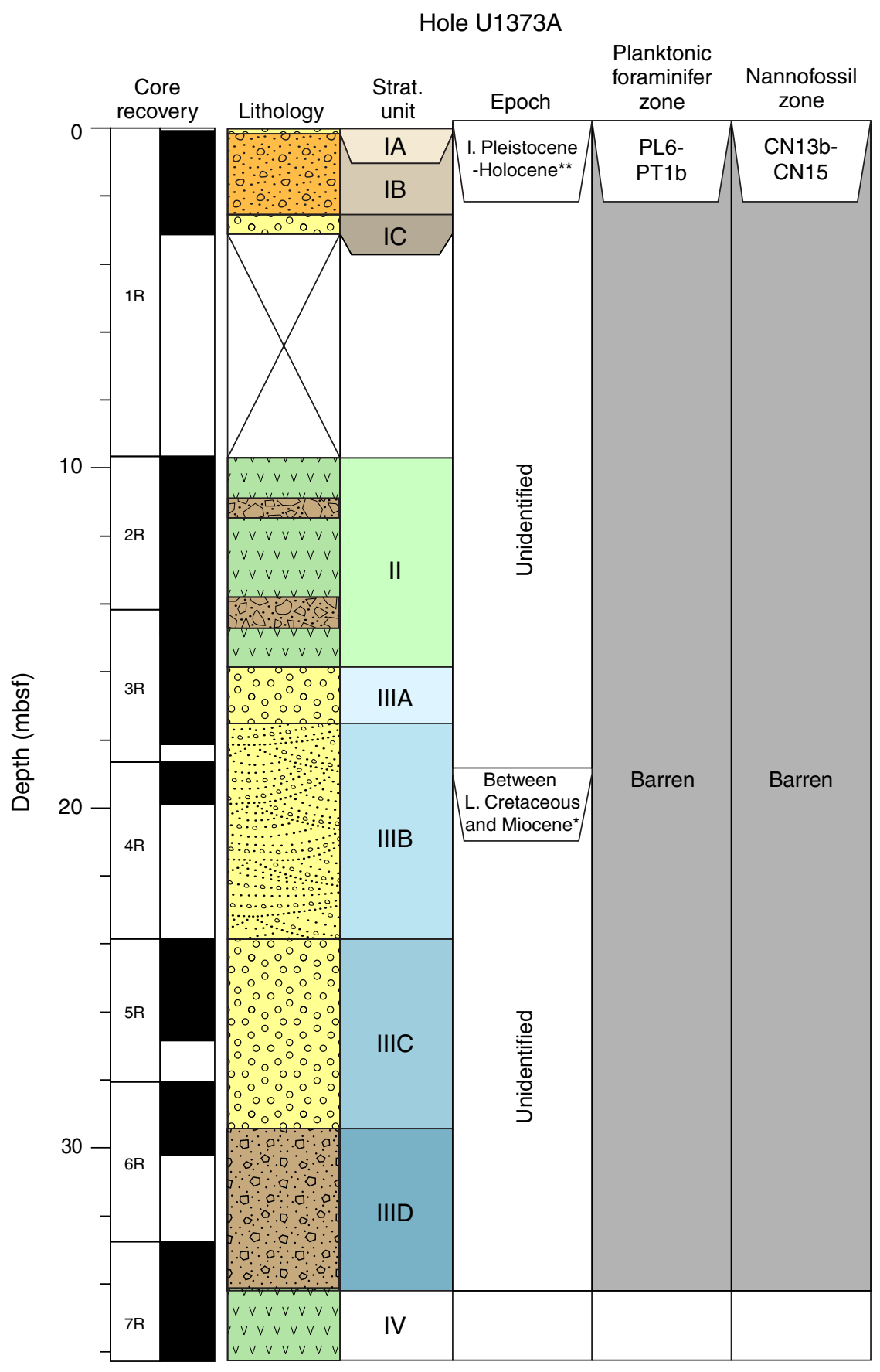


Figure F9. Close-up photographs of Flemingostrea sp. in Subunit IIIB. A. Outer mold of anterior view, Sample 330-U1373A-4R-1, 67-71 cm. B. External view, Sample 330-U1373A-4R-1, 78-82 cm.

A

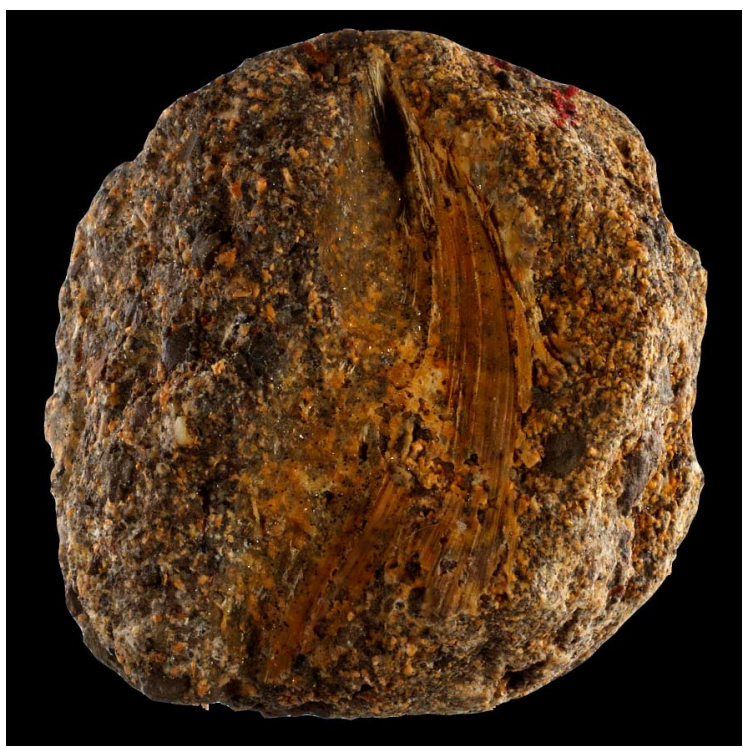

$3 \mathrm{~cm}$
B

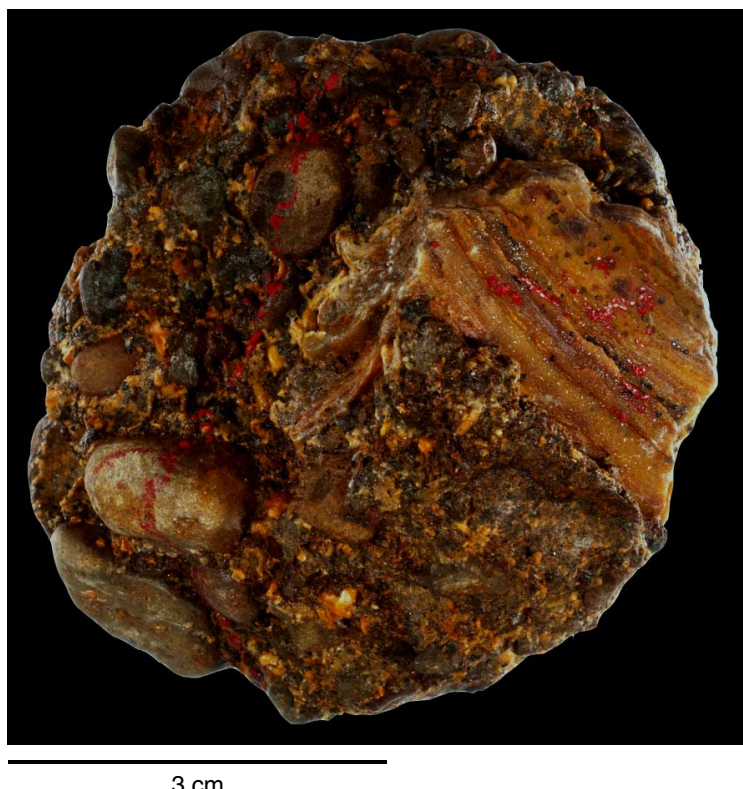


Figure F10. Thin section photomicrographs of Flemingostrea sp. in Subunit IIIB (Sample 330-U1373A-4R-1W, 86-89 cm; Thin Section 85). A. Plane-polarized light. B. Crossed polars. White box in A indicates area of B.

A

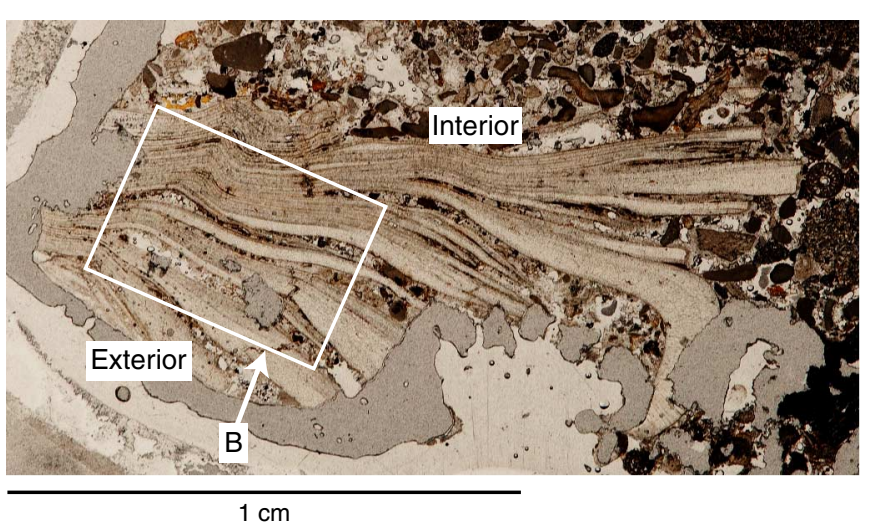

B

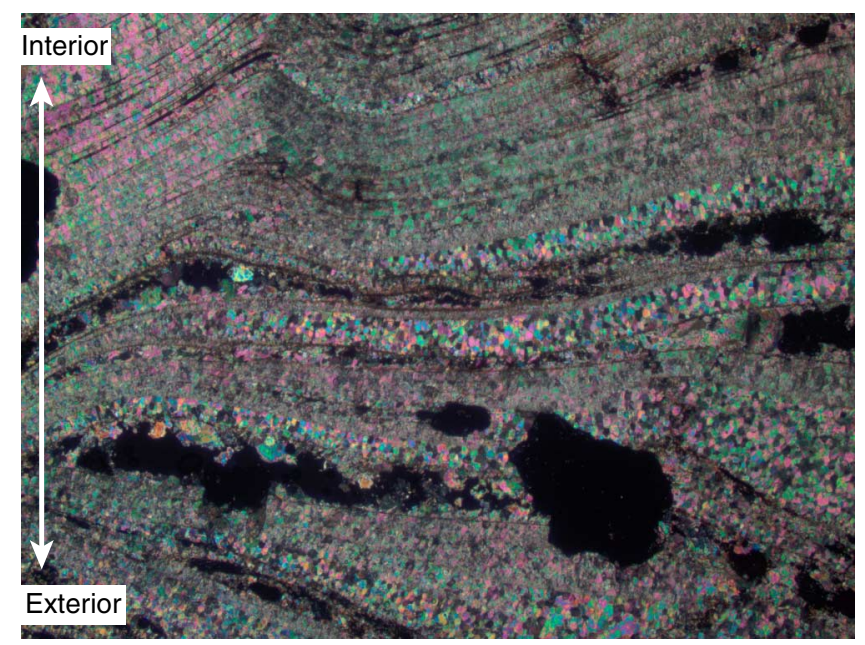

$1 \mathrm{~mm}$ 
Figure F11. Stratigraphic summary of igneous rocks, showing lithology and volcanological features, Hole U1373A.

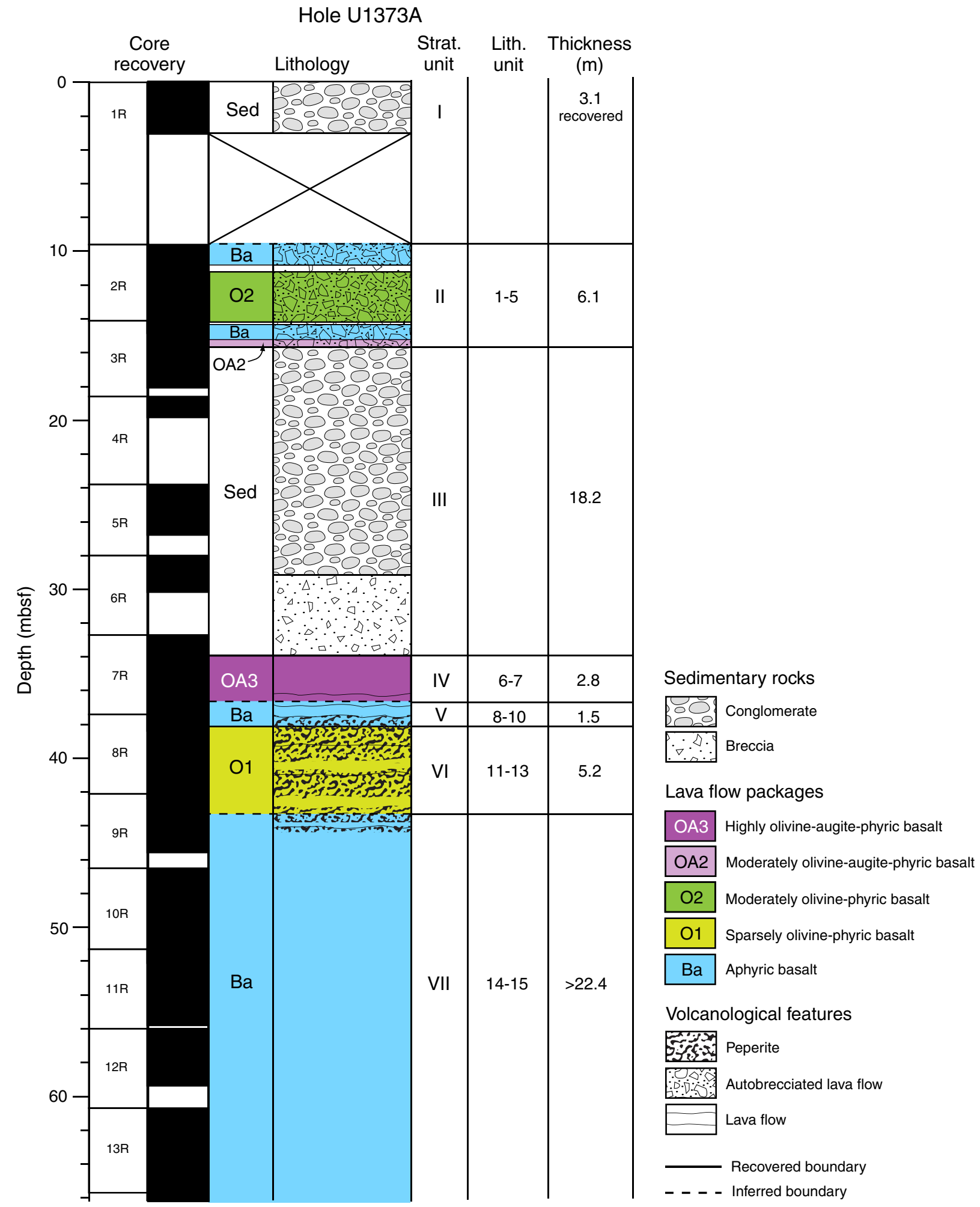


Figure F12. Thin section photomicrographs of highly olivine-titanaugite-plagioclase-phyric basalt from a Type 7 clast in the conglomerate forming Subunit IB (Sample 330-U1373A-1R-2W, 123-125 cm; Thin Section 76). A. Plane-polarized light. B. Crossed polars. White box indicates area of Figure F13.

A

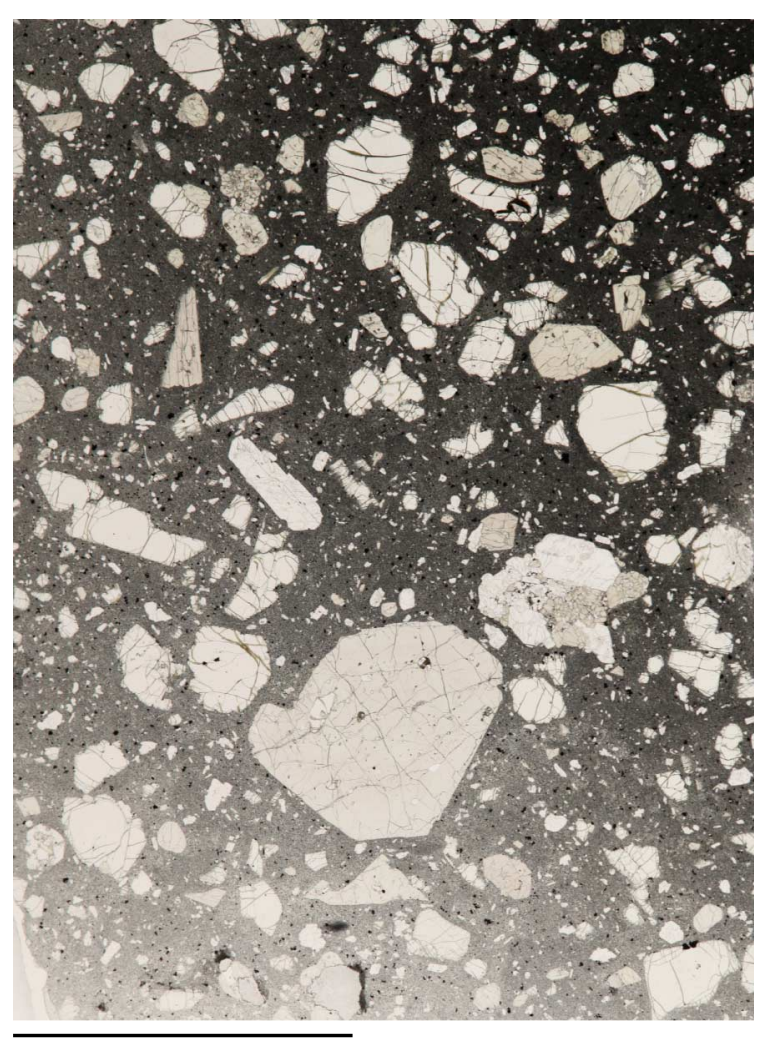

$10 \mathrm{~mm}$
B

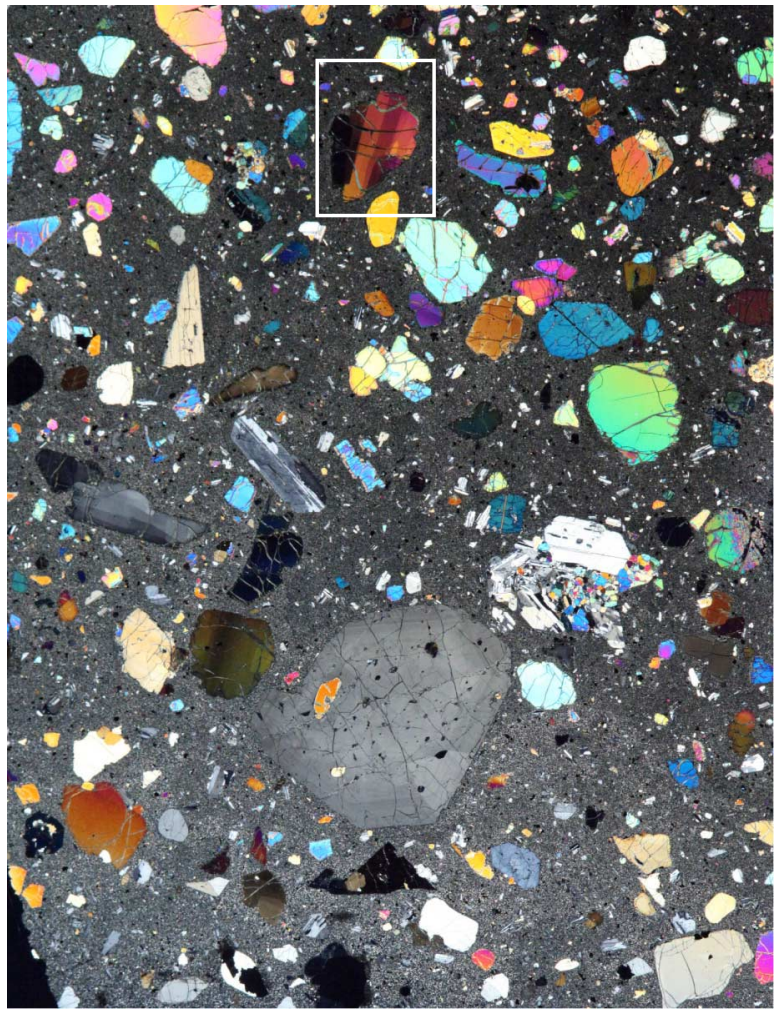

$10 \mathrm{~mm}$ 
Figure F13. Thin section photomicrograph of strained olivine crystal in Figure F12 (Sample 330-U1373A-1R2W, 123-125 cm; Thin Section 76) (crossed polars).

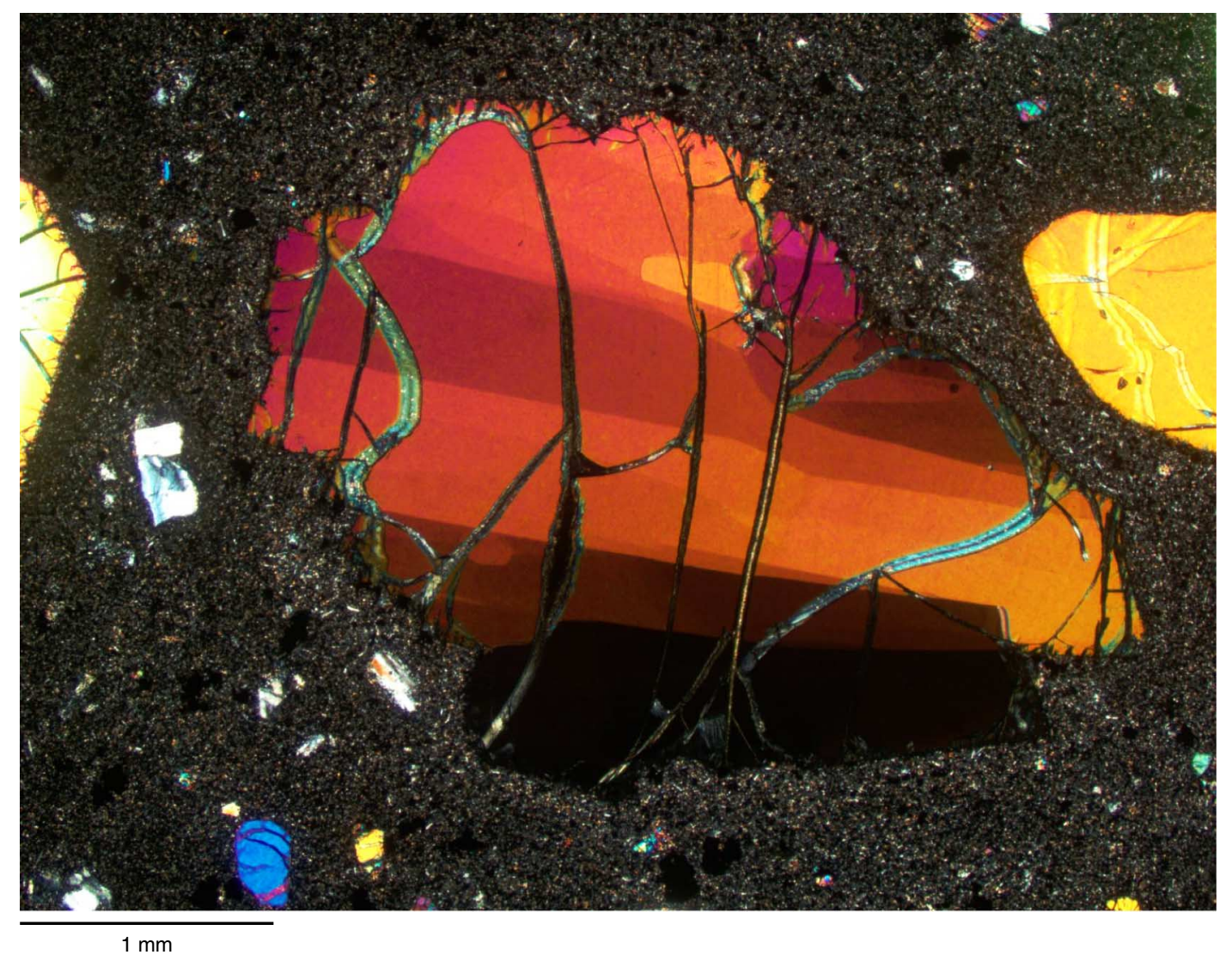


Figure F14. Scanned core photograph of basaltic clast in conglomerate forming Subunit IB (interval 330U1373A-1R-2A, 60-64 cm). Lobate margins and delicate protrusions show that the clast cannot have been transported far and may have formed in situ through peperitic interaction between magma and soft sediment.

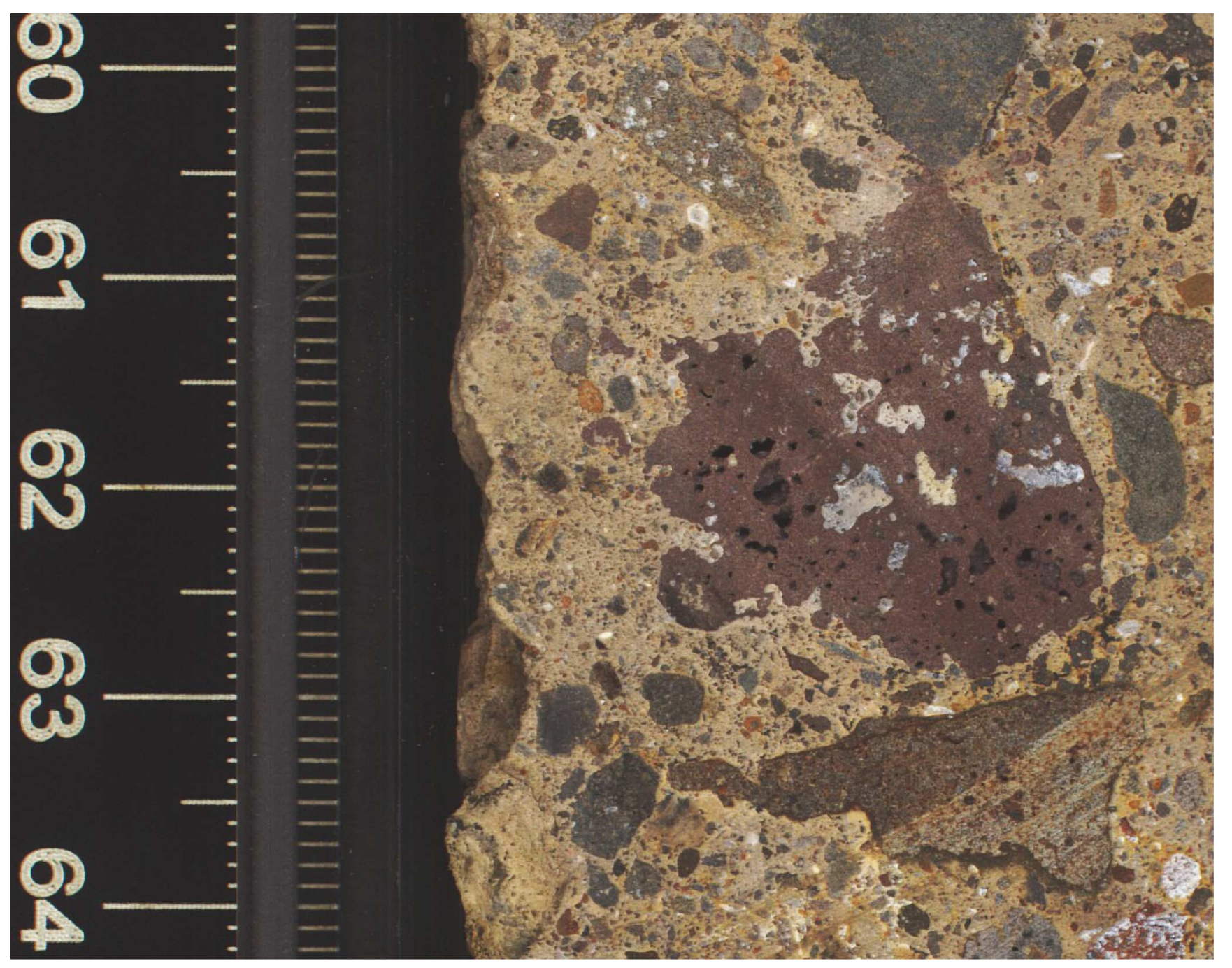


Figure F15. Scanned core photograph of jigsaw-fit clasts in basaltic breccia from Unit II (interval 330-U1373A2R-1A, 108-119 cm). This type of jigsaw-fit texture is a common feature of blocky peperites and is thought to reflect in situ quench fragmentation.

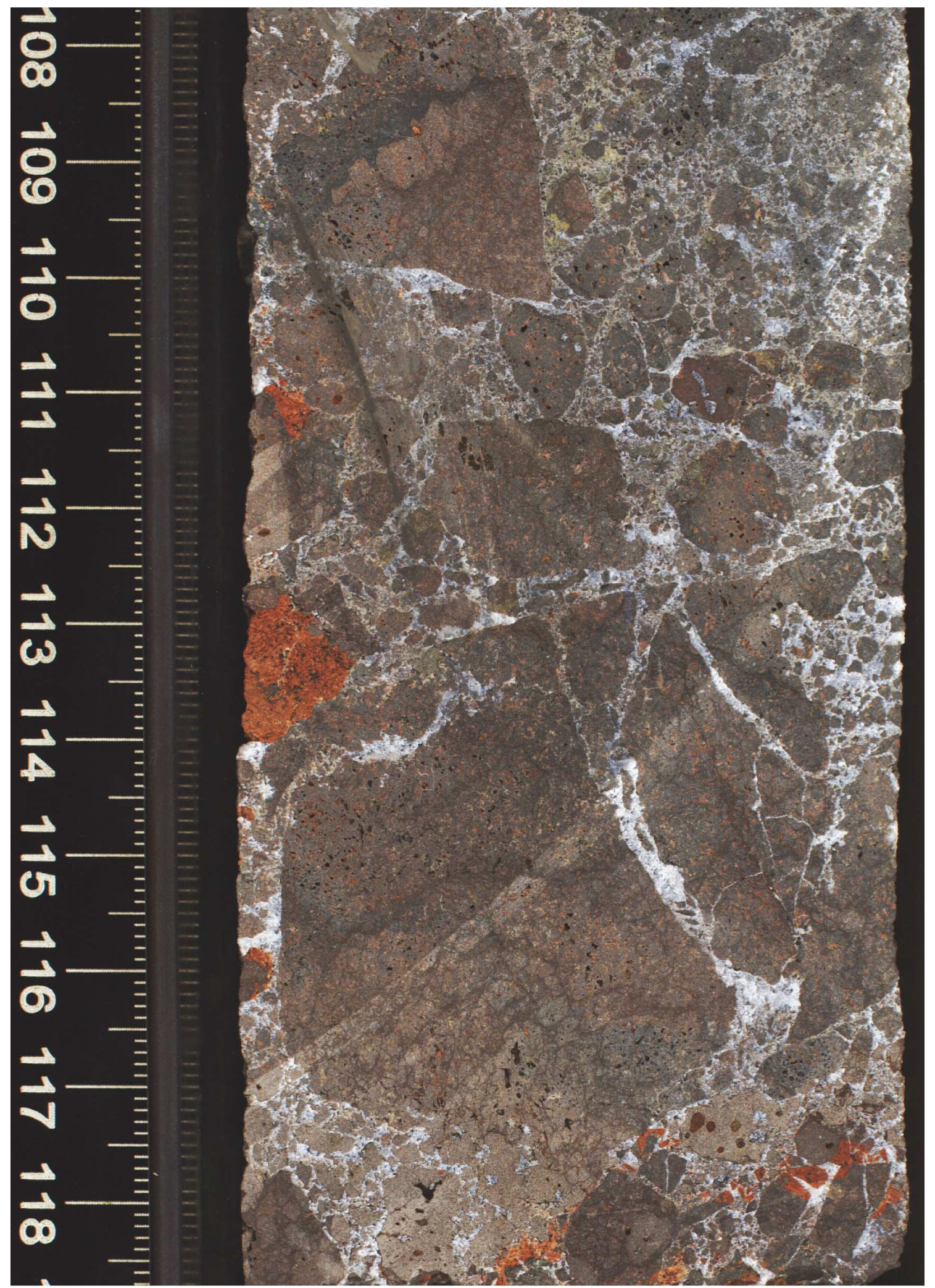


Figure F16. Thin section photomicrographs of highly olivine-titanaugite-phyric basalt from lava flow in Unit IV (Sample 330-U1373A-7R-2W, 128-130 cm; Thin Section 90). A. Plane-polarized light. B. Crossed polars.

A

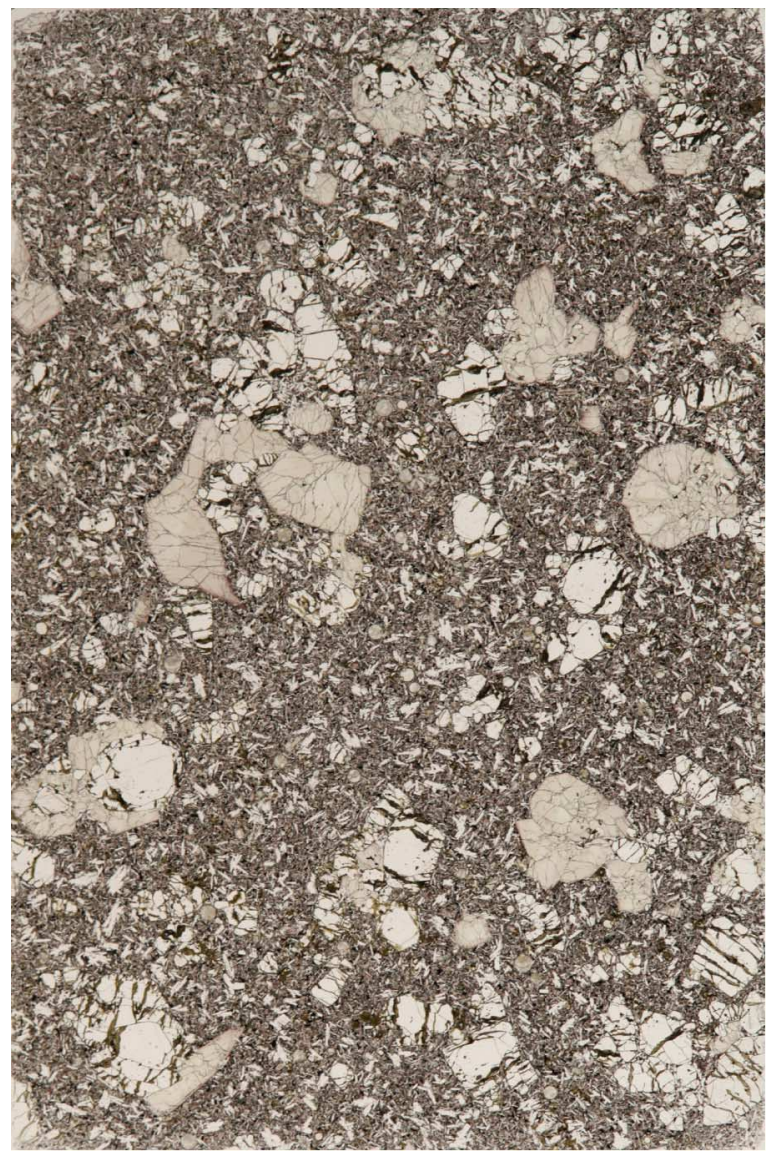

$10 \mathrm{~mm}$
B

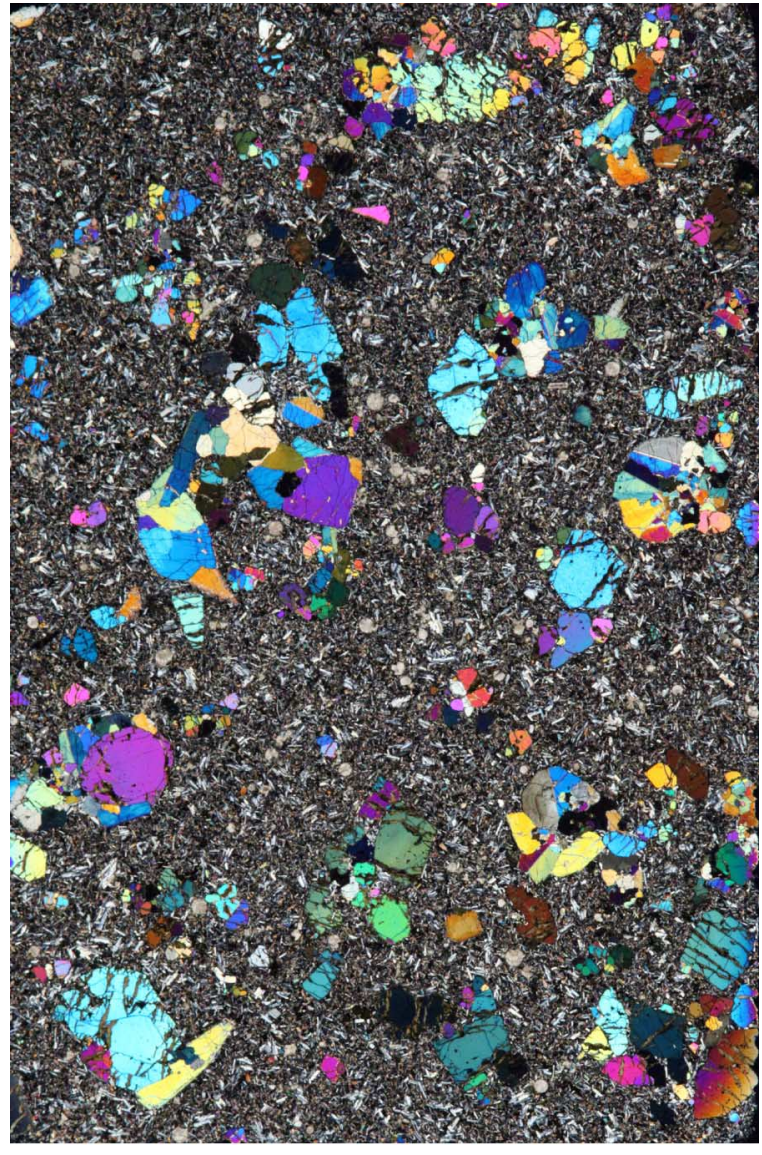

$10 \mathrm{~mm}$ 
Figure F17. Scanned core photograph of peperitic top of thick ( $>21 \mathrm{~m}$ ) lava flow forming most of Unit VII (interval 330-U1373A-9R-2A, 67-80 cm). Basaltic clasts (reddish gray) with lobate margins are mingled with finegrained sediment (dull green).

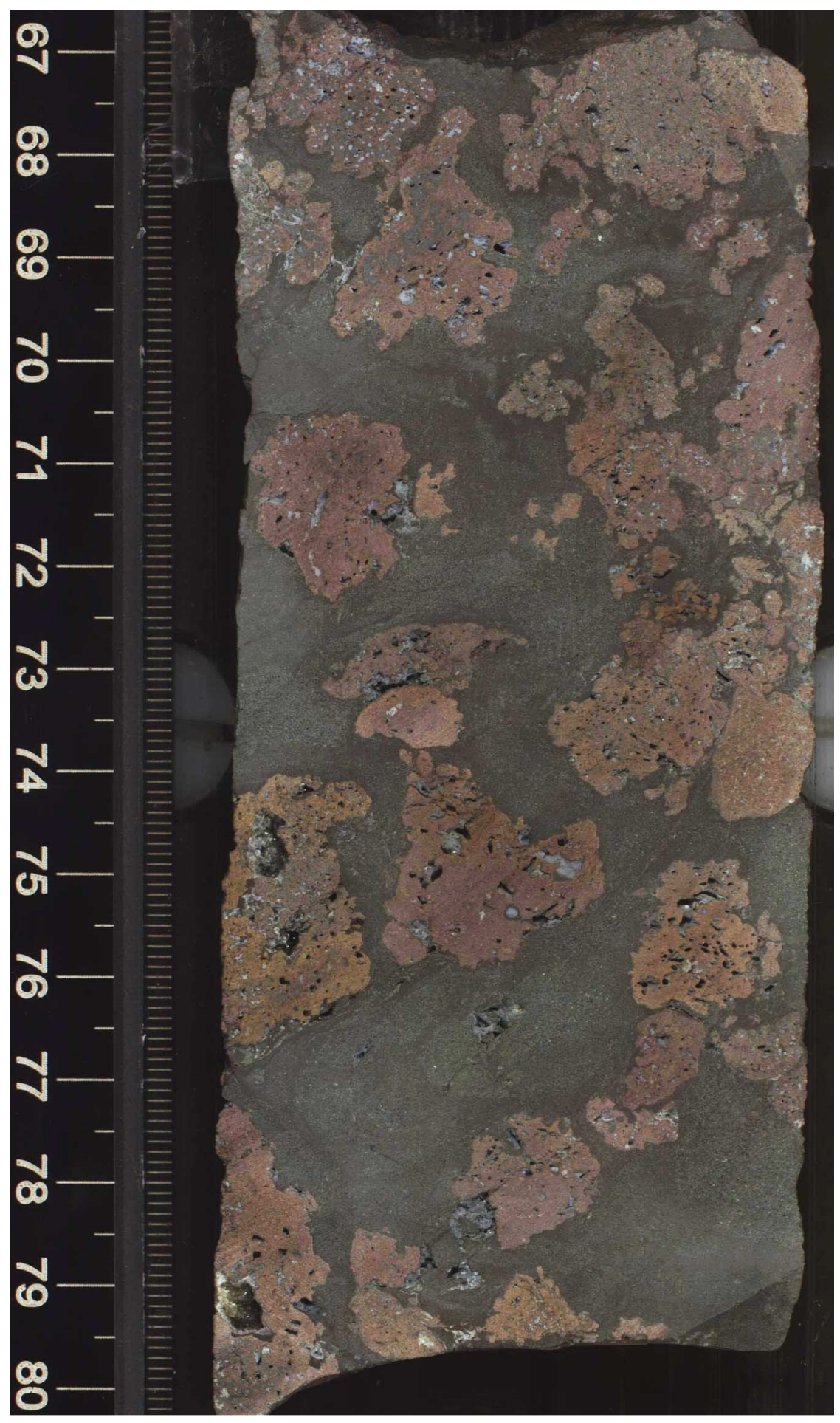


Figure F18. Plot of downhole distribution of percentage of groundmass alteration for each interval defined by the alteration petrology group. Circles are located at center depth for each interval. Gray shading represents sedimentary units.

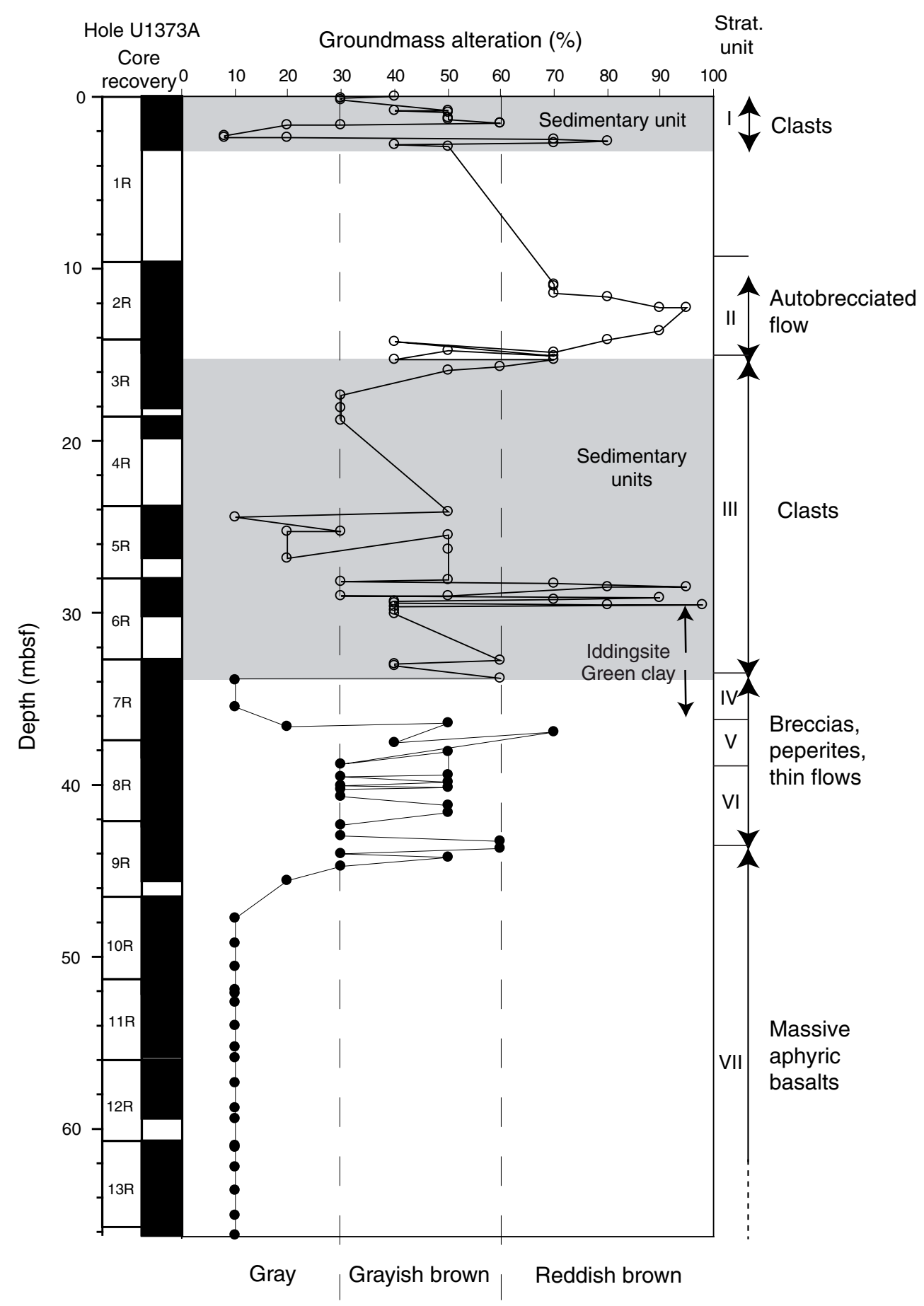


Figure F19. Plot of downhole distribution of secondary minerals after olivine for each interval defined by the alteration petrology group. Symbols are located at center depth for each interval. Occurrences of fresh to slightly altered olivines are reported by macroscopic observations; for thin section observations, see Table T6. Gray shading represents sedimentary units.

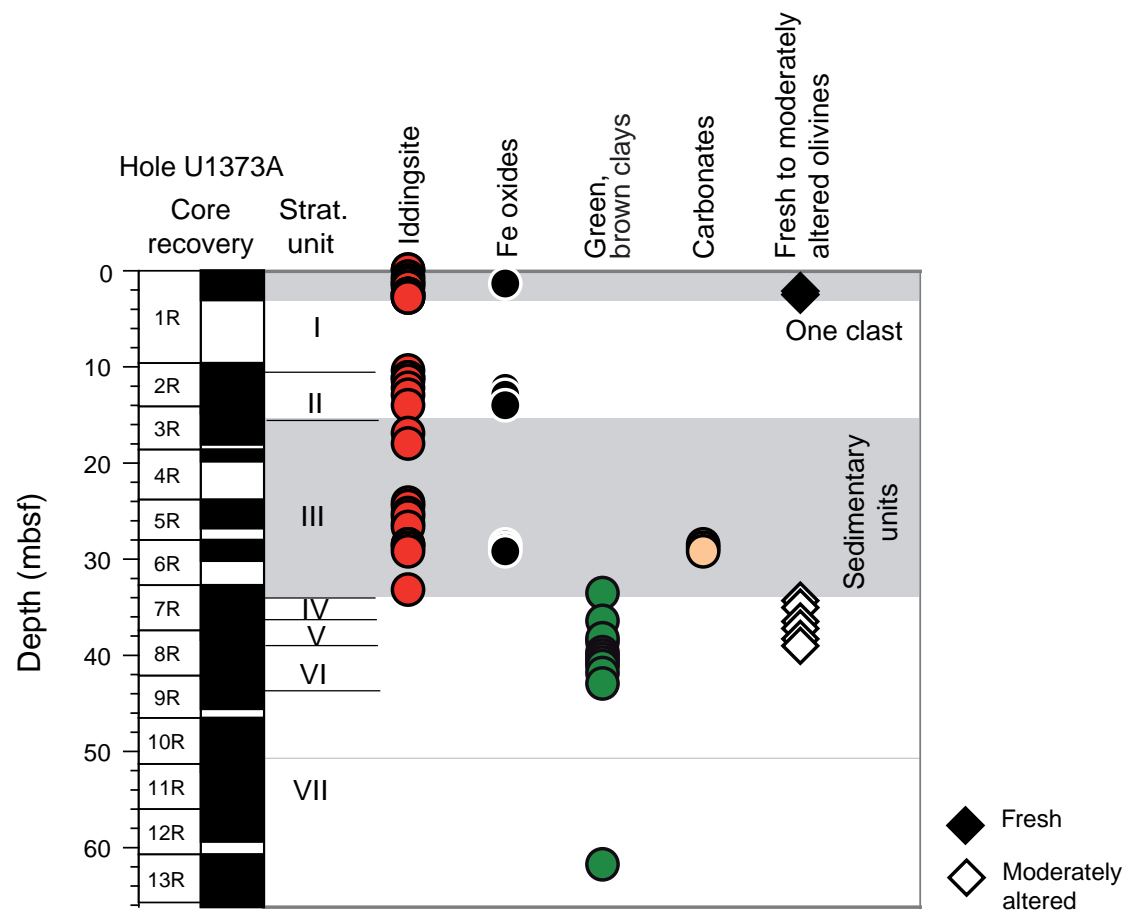


Figure F20. Thin section photomicrographs of partly altered olivine (each pair is shown under plane-polarized light and crossed polars). A, B. Unaltered augite and fresh to slightly altered olivine showing presence of brown and green clay in fractures (Sample 330-U1373A-1R-2, 123-125 cm; Thin Section 76). C, D. Slightly altered olivine with brown and green clay and probably chrysotile in fractures (highly olivine-augite-phyric basalt) (Sample 330-U1373A-7R-2, 128-130 cm; Thin Section 90). E, F. Fracture in olivine filled with green clay at margins and probably late chrysotile in interior (highly olivine-augite-phyric basalt) (Sample 330-U1373A-7R3, 109-111 cm; Thin Section 92).

A

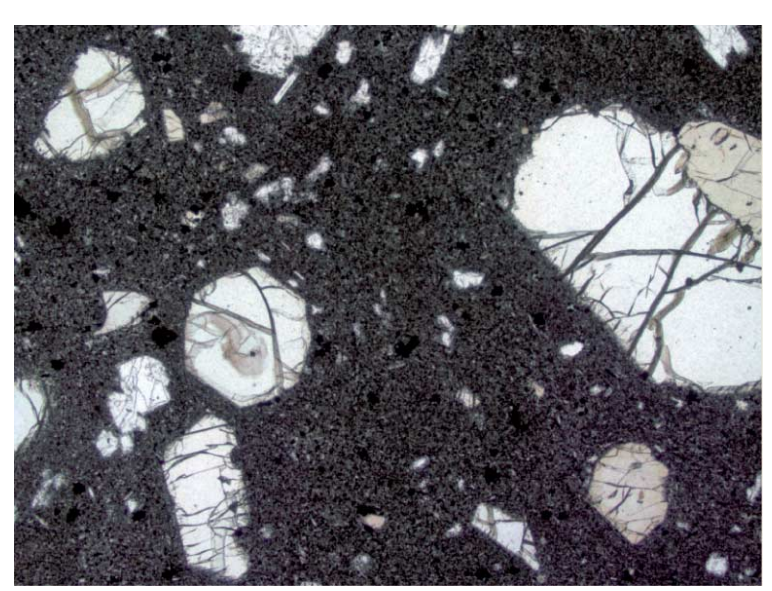

C

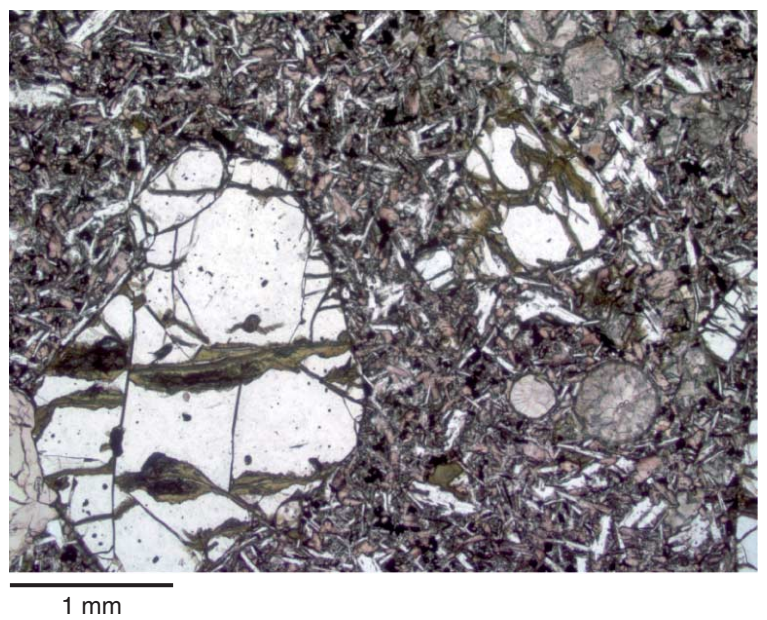

E

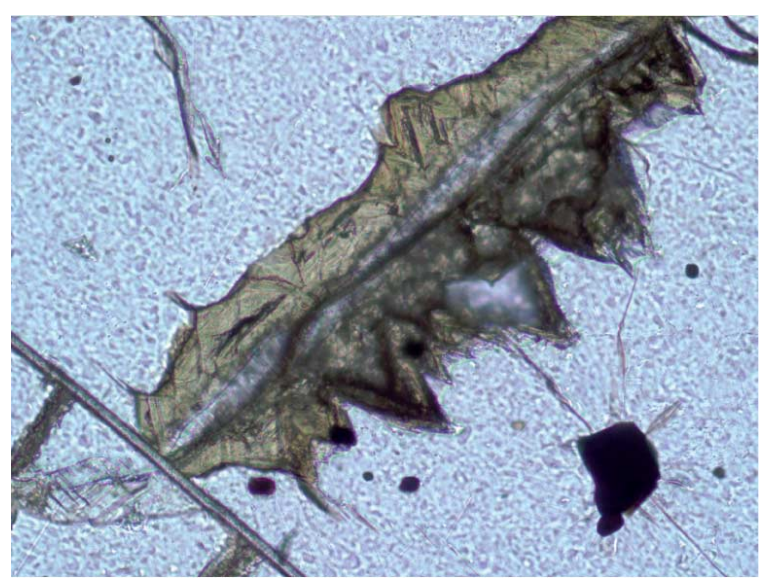

$0.1 \mathrm{~mm}$
B

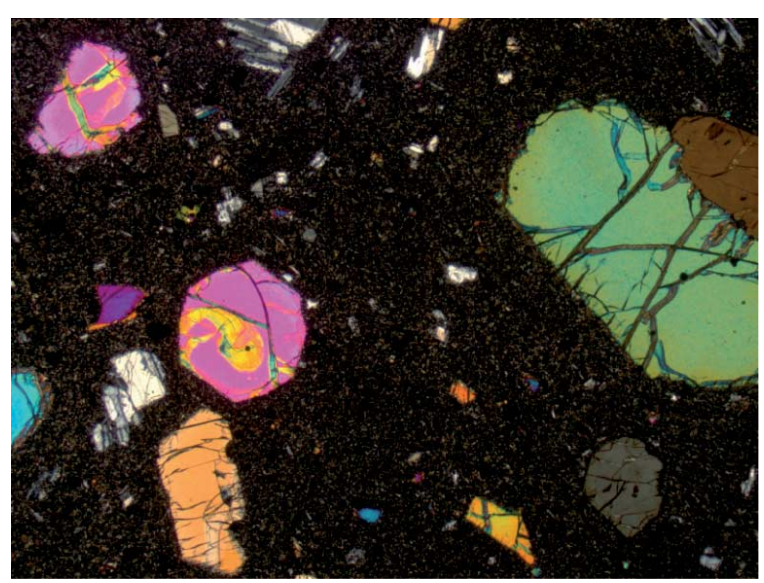

$1 \mathrm{~mm}$

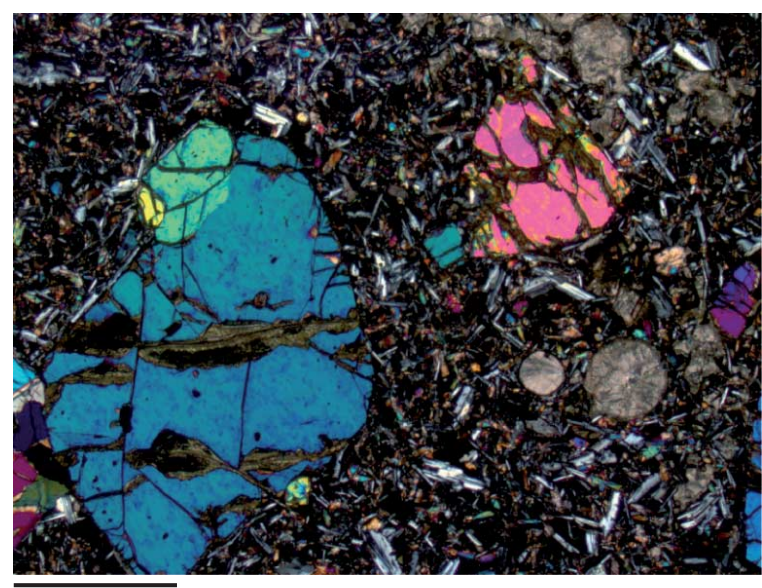

F

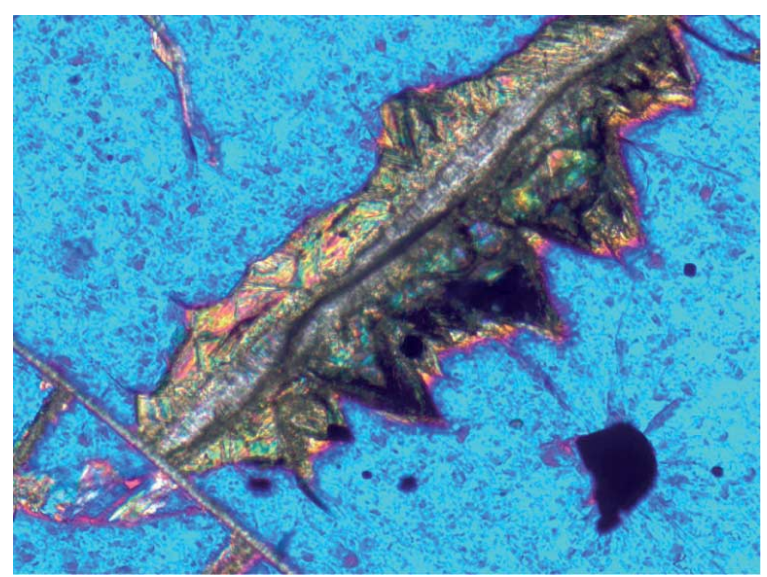

$0.1 \mathrm{~mm}$ 
Figure F21. Thin section photomicrographs of completely altered olivine (plane-polarized light). A. Completely altered olivine showing thin rim of iddingsite and an interior of green clay and carbonate (highly olivine-augite-phyric basalt) (Sample 330-U1373A-2R-3, 133-135 cm; Thin Section 78). B. Completely altered microphenocrysts of olivine to iddingsite (aphyric to moderately olivine-phyric basalt breccia) (Sample 330U1373A-2R-3, 133-135 cm; Thin Section 78). C. Completely altered olivine to brown (saponite) clay minerals and Fe oxyhydroxides (aphyric to moderately olivine-phyric basalt breccia) (Sample 330-U1373A-2R-3, 133$135 \mathrm{~cm}$; Thin Section 78).
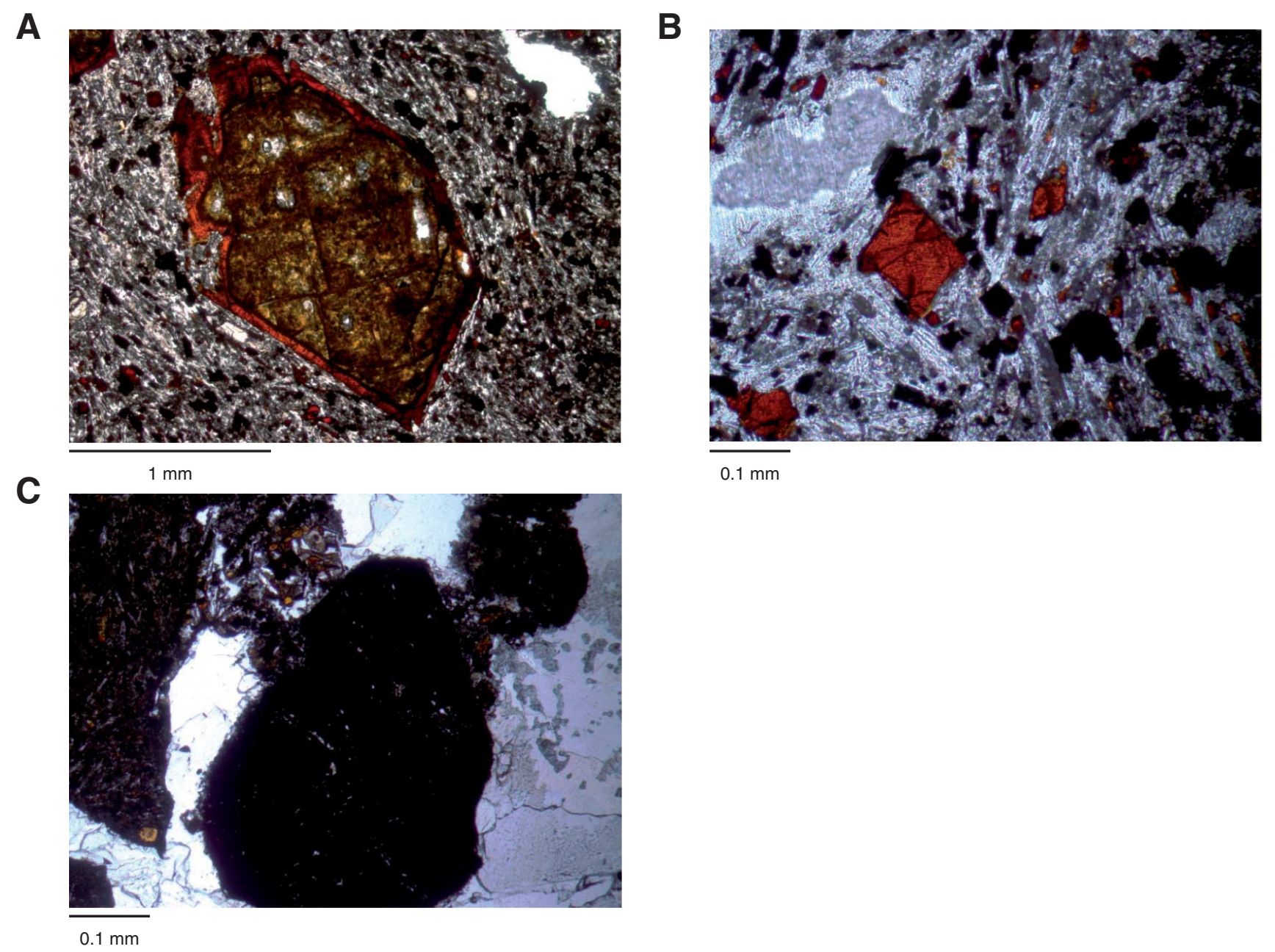
Figure F22. X-ray diffraction spectra and associated core photograph (Sample 330-U1373A-2R-3, 111-116 cm). Material from several altered olivine phenocrysts (red circles) was combined for a single XRD analysis. The secondary mineral assemblage is predominantly composed of hematite, montmorillonite, and bannisterite. Minor amounts of $\mathrm{Mg}$ calcite may also be present as small peaks (not labeled). The presence of augite in the X-ray pattern is due to inclusion of the adjacent groundmass during sample extraction.

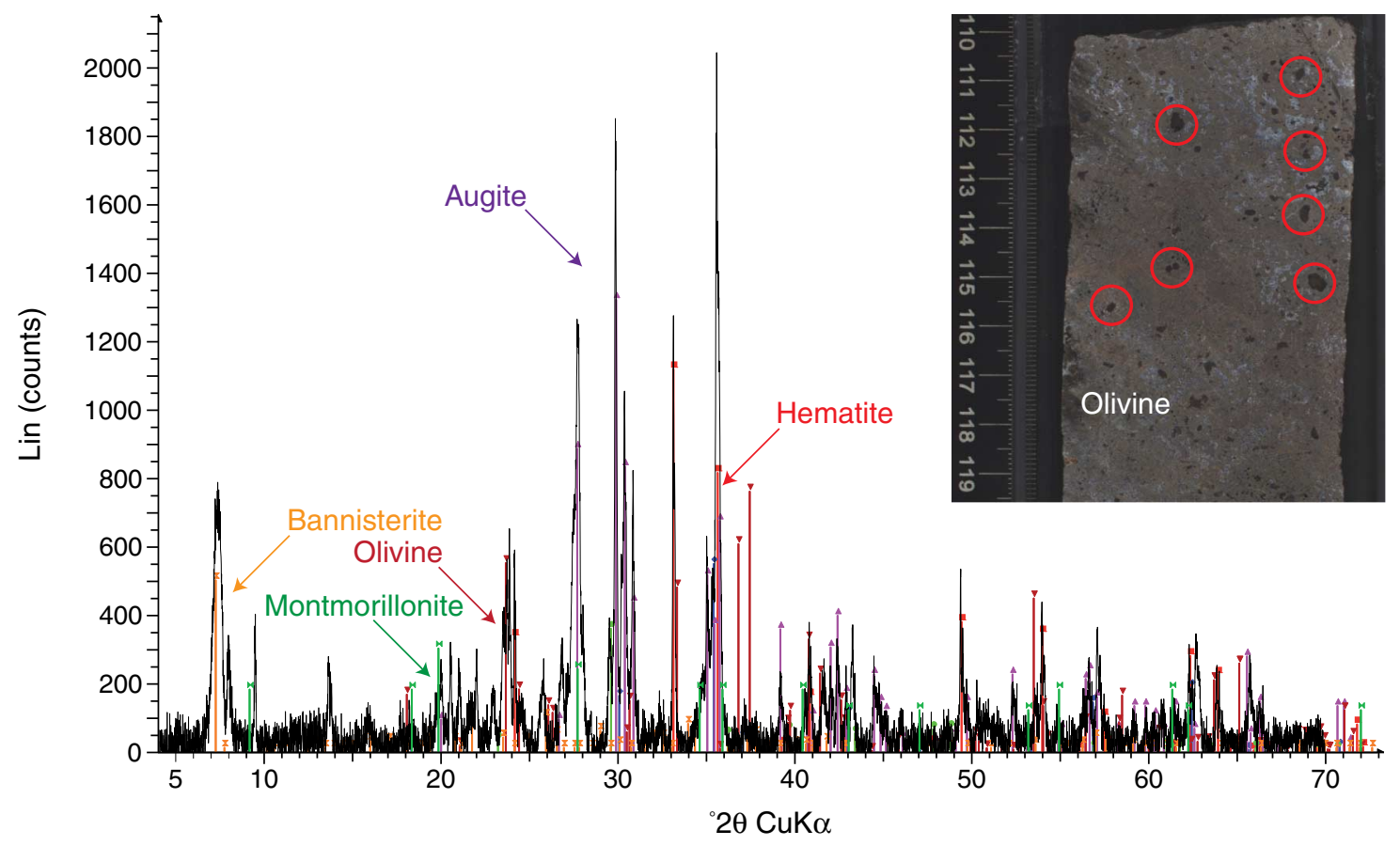


Figure F23. X-ray diffraction spectra and associated core photograph (Sample 330-U1373A-8R-4, 48-52 cm). A. Vugs and vesicles showing filling with zeolites (chabazite and phillipsite) and nontronite (blue coating of vesicles). Blue lines $=$ phillipsite, green lines $=$ nontronite. Red circle $=$ analyzed zone. $\mathbf{B}$. Vein predominantly composed of Mg calcite. Green oval = analyzed zone.

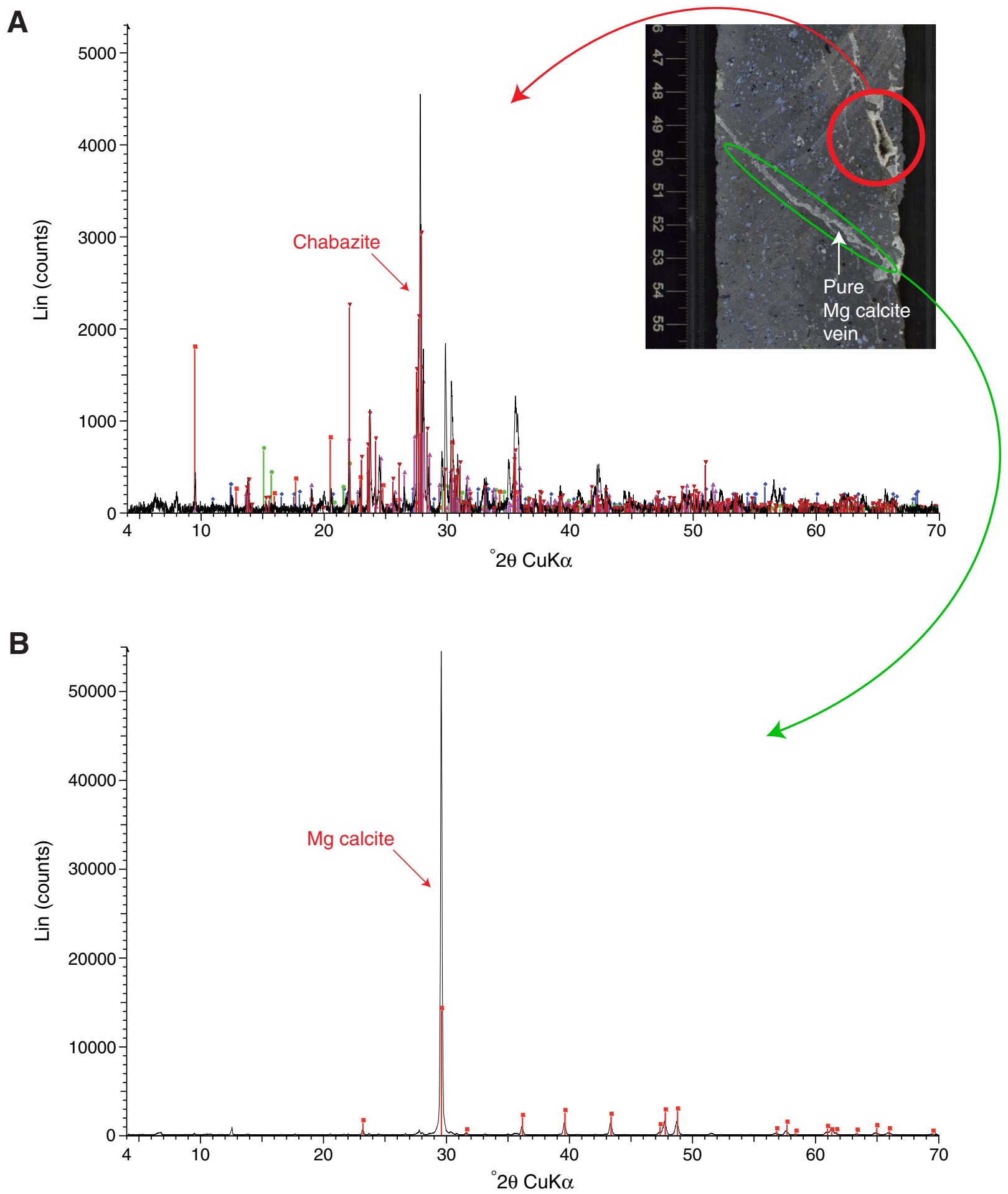


Figure F24. X-ray diffraction spectra and associated core photographs. Red ovals = analyzed zones. A. Composite banded vein (Sample 330-U1373A-7R-2, 141-142 cm) filled with Mg calcite, clay minerals (bannisterite and saponite), and small proportions of pyrite/chalcopyrite (pink lines). B. Composite and banded vein (Sample 330-U1373A-10R-2, 108-110 cm) filled with Mg calcite, aragonite, clay minerals (green lines = montmorillonite, blue lines = saponite), and small proportions of pyrite/chalcopyrite (pink lines).
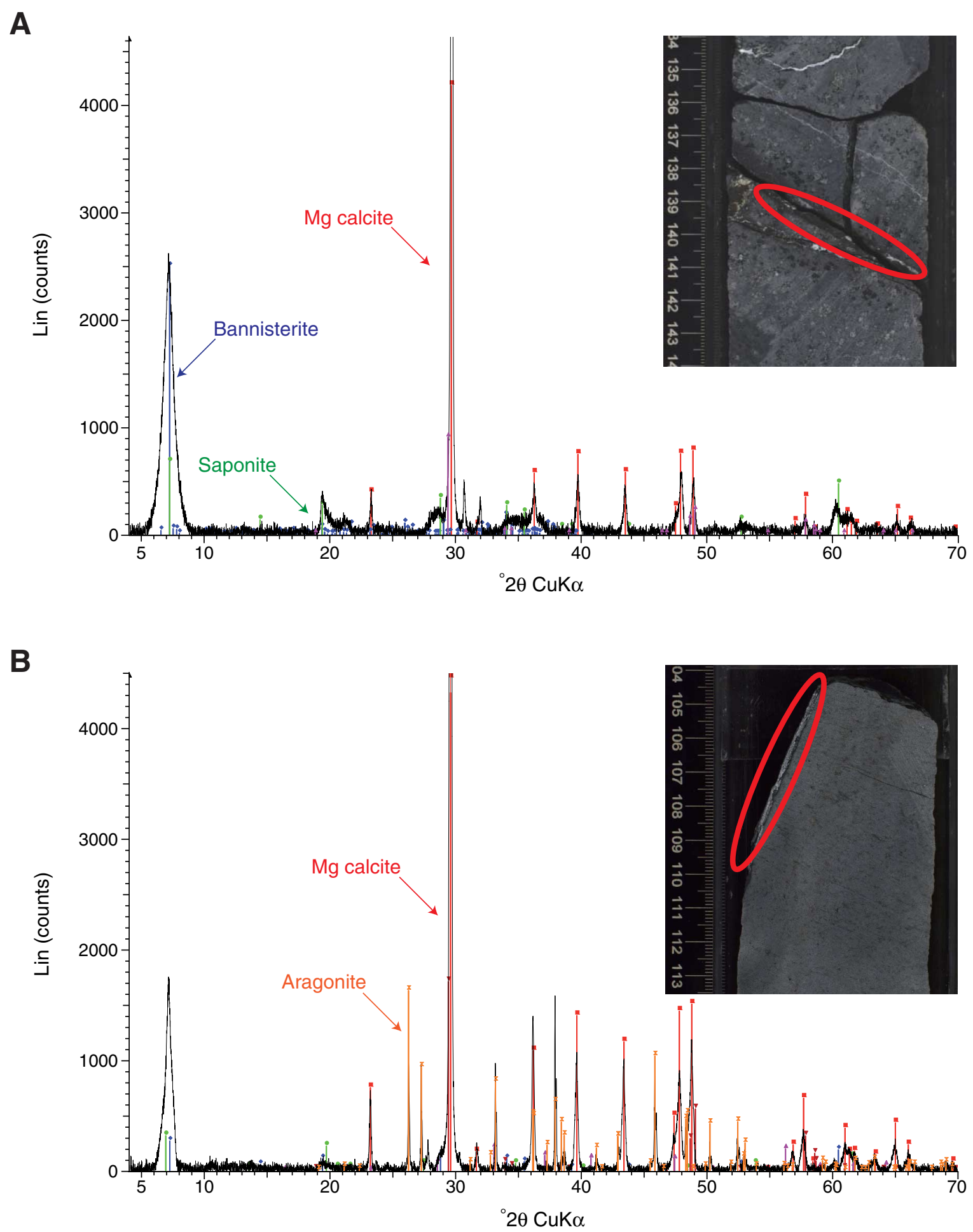
Figure F25. X-ray diffraction spectra and associated close-up photographs. A. Vug (Sample 330-U1373A-9R-1, $102-103 \mathrm{~cm}$ ) partially filled with $\mathrm{Mg}$ calcite, zeolite (chabazite and phillipsite), and clay minerals (nontronite) (Mg calcite, phillipsite, and nontronite not labeled). Arrow points to core top. B. Vug (Sample 330-U1373A-8R2, 29-31 cm) partially filled with $\mathrm{Mg}$ calcite, zeolite (chabazite), and clay minerals (nontronite, montmorillonite, and celadonite) (Mg calcite and nontronite not labeled). Red circle = analyzed zone.
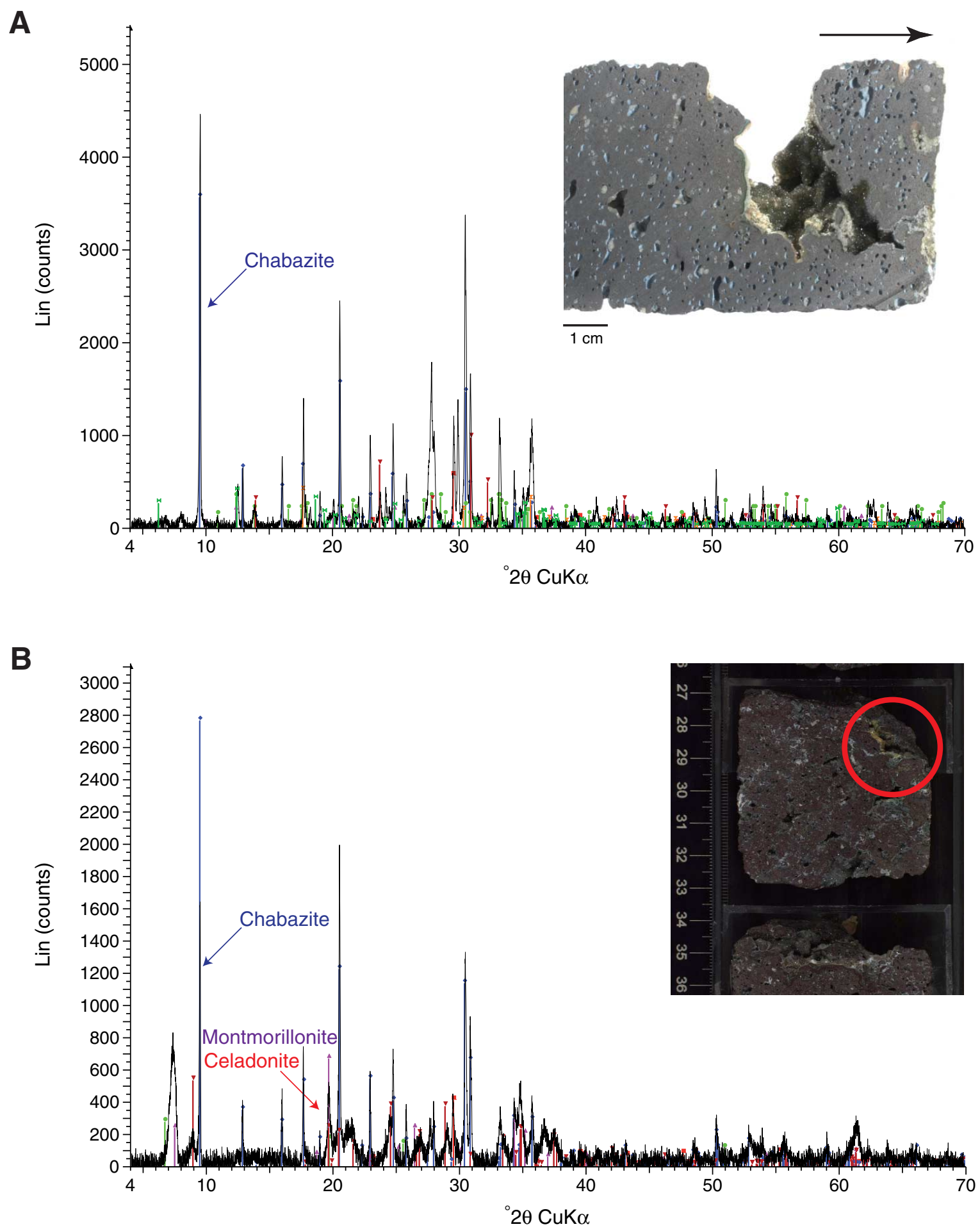
Figure F26. X-ray diffraction spectra and associated core photographs (red circles = analyzed zones). A. Vug (Sample 330-U1373A-8R-2, 22-24 cm) filled with Mg calcite and zeolite (chabazite and phillipsite). B. Vugs (Sample 330-U1373A-7R-4, 36-41 cm) filled with Mg calcite, zeolite (phillipsite, not labeled), clay minerals (montmorillonite and saponite), and small proportions of clinochlore.

A

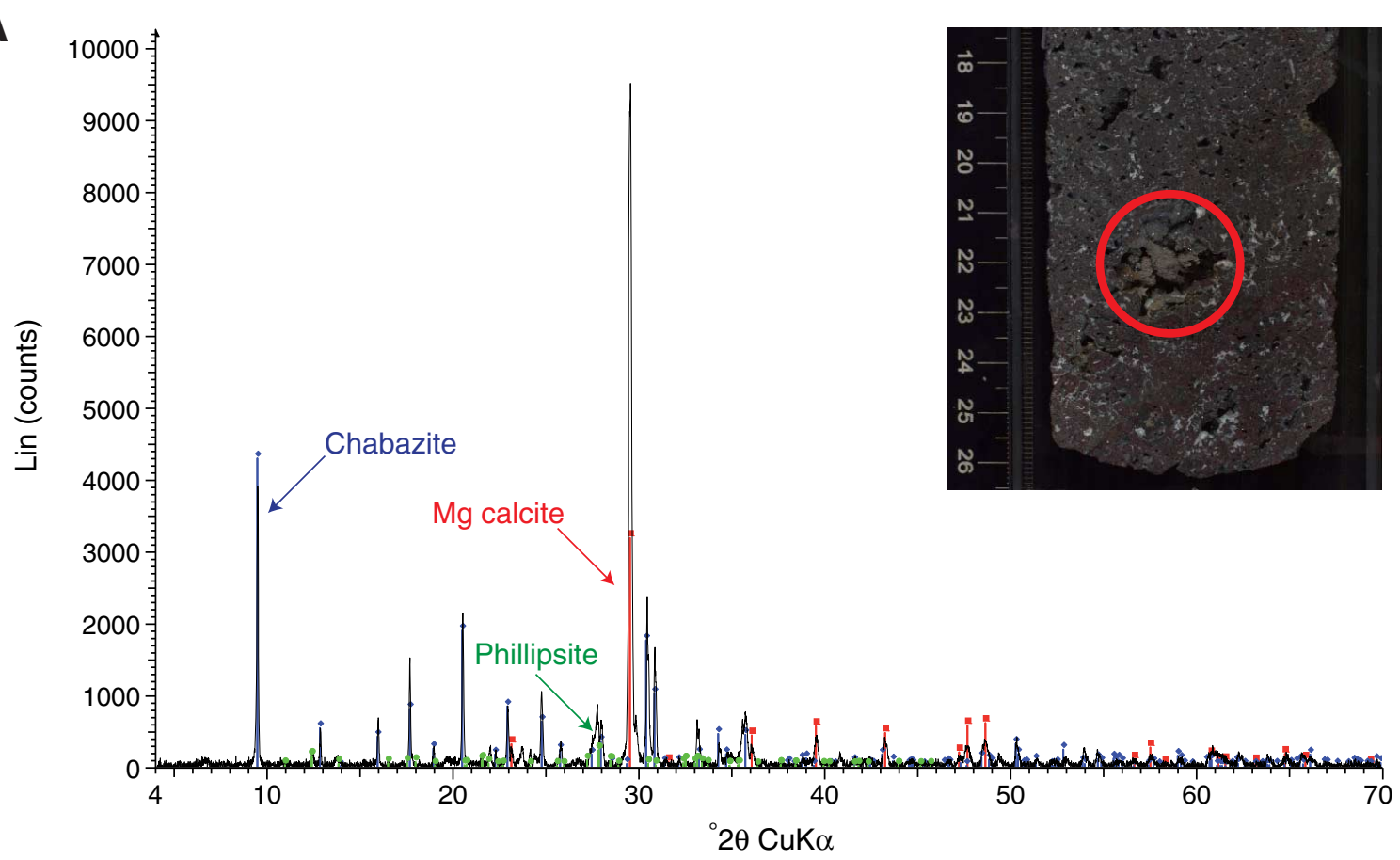

B

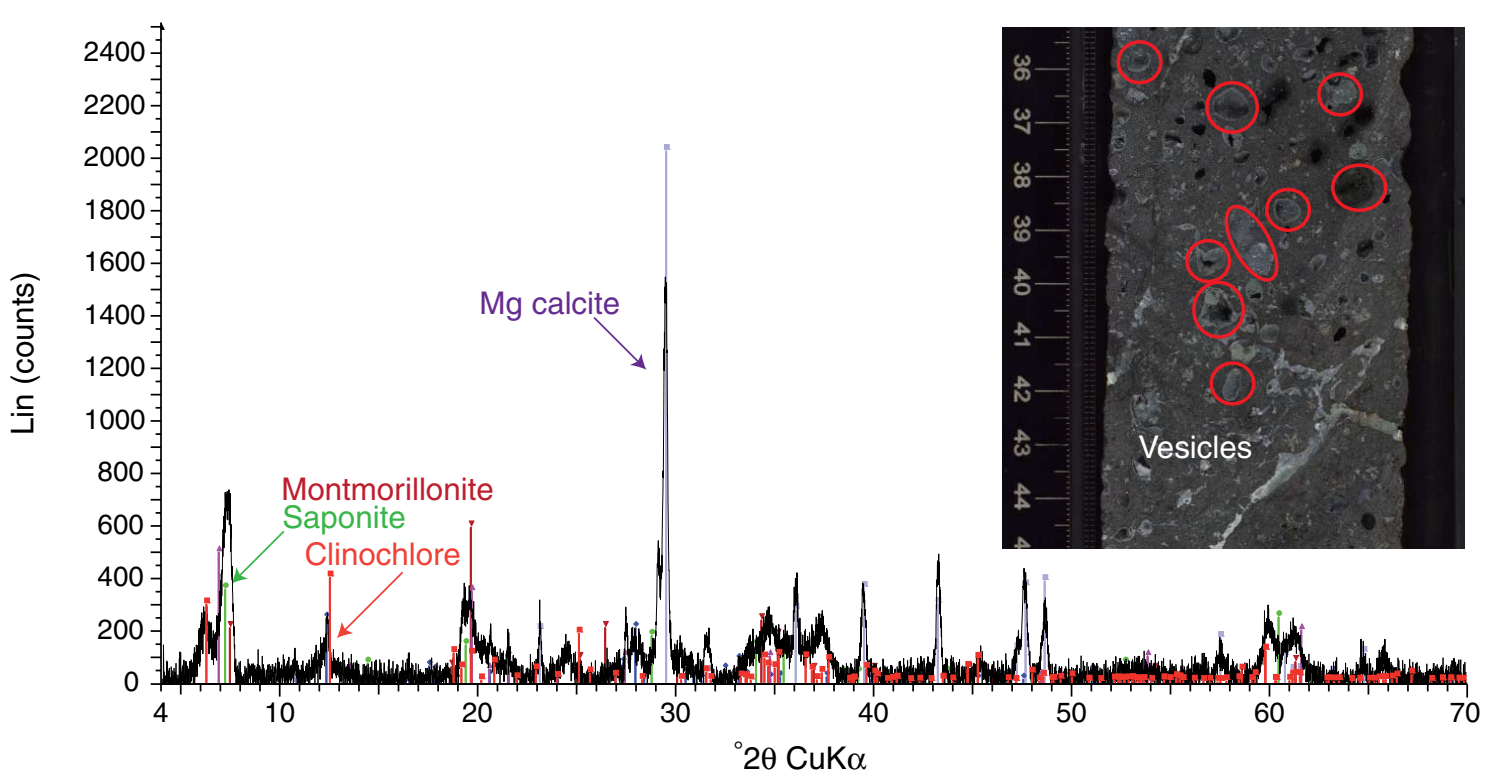


Figure F27. Plot of downhole distribution of main alteration colors representing overall color of each lithologic unit (units defined by the igneous petrology group). Circles are located at center depth for each unit. For some units, especially those where volcanic clasts are surrounded by a volcanic matrix, the color of both clasts and cement is reported. Gray shading represents sedimentary units.

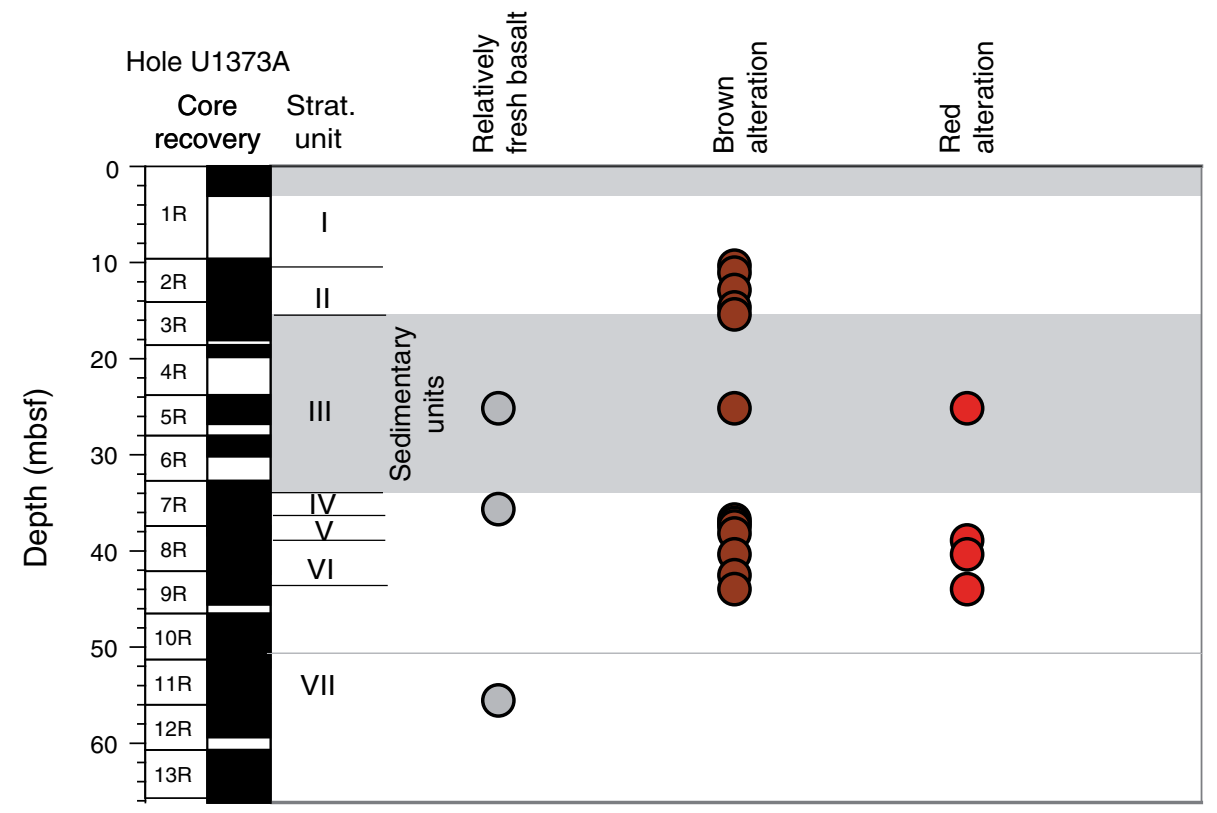


Figure F28. Plot of downhole distribution of alteration color for each alteration interval defined by the alteration petrology group. Circles are located at center depth for each interval. Gray shading represents sedimentary units.

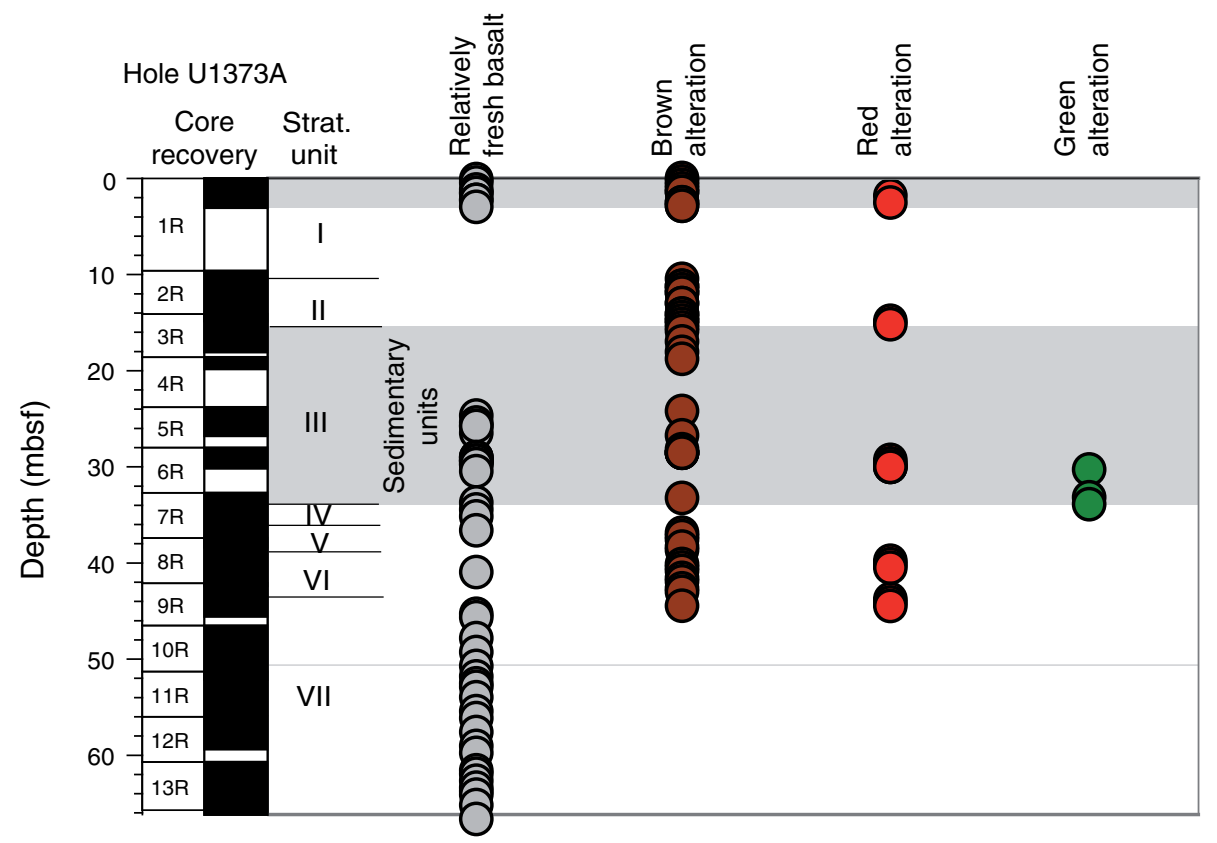


Figure F29. Plot of downhole distribution of secondary minerals infilling vesicles for each alteration interval defined by the alteration petrology group. Symbols are located at center depth for each interval. Gray shading represents sedimentary units.

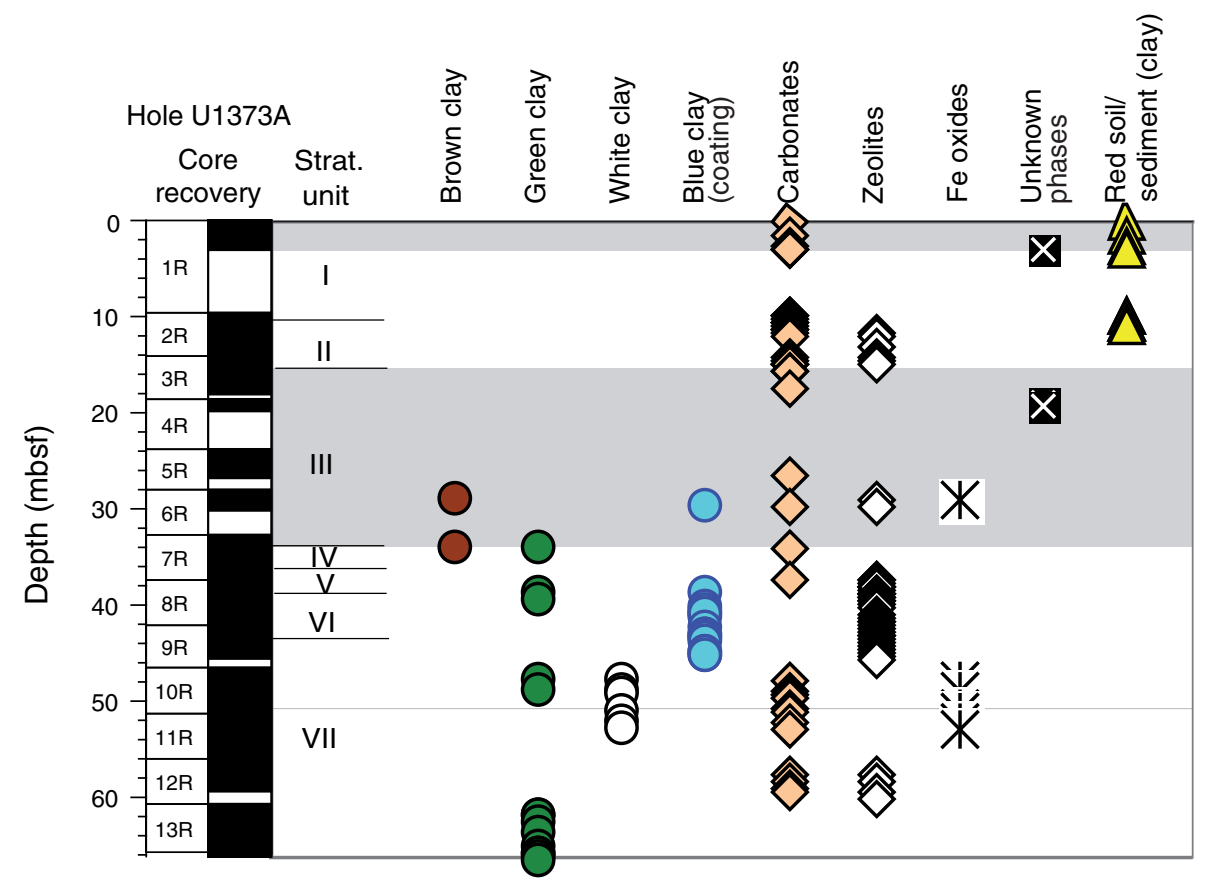


Figure F30. Thin section photomicrographs of vesicles. A, B. Subelongate, rounded vesicle in aphyric basaltic lava flow filled with fibrous brown clay (Sample 330-U1373A-9R-3, 39-41 cm; Thin Section 102): (A) plane-polarized light, (B) crossed polars. C, D. Vesicle in highly olivine-augite-phyric basalt filled with brown and green clay along the margins and zeolites in interior (Sample 330-U1373A-7R-1, 84-86 cm; Thin Section 89): (C) plane-polarized light, (D) crossed polars. E. Vesicles in highly olivine-augite-phyric basalt filled with botryoidal green and brown clay (Sample 330-U1373A-7R-1, 84-86 cm; Thin Section 89; plane-polarized light). F. Vesicle in sparsely olivine-phyric basalt. The hand sample contained vesicles with a blue coating; the thin section reveals an initial layer of brown clay minerals coated by a thin layer of a translucent mineral; the remainder is void space (Sample 330-U1373A-8R-2, 112-115 cm; Thin Section 97; plane-polarized light).

A

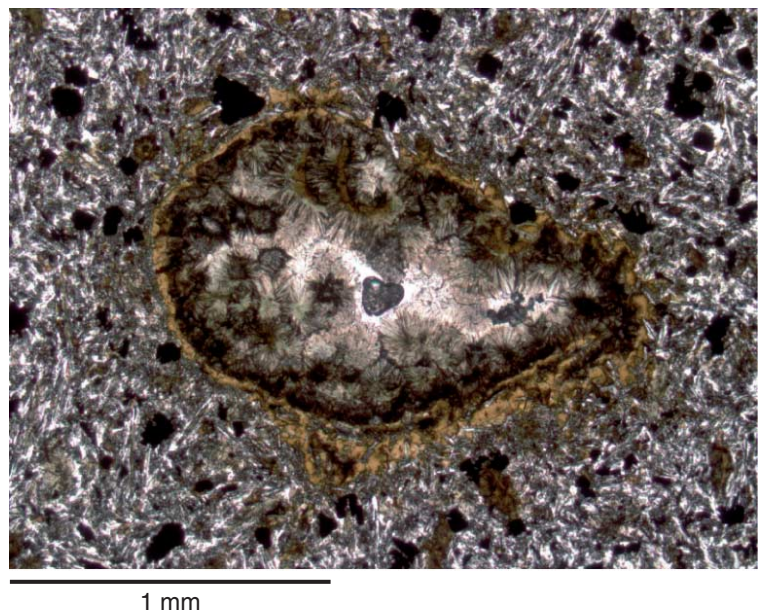

C

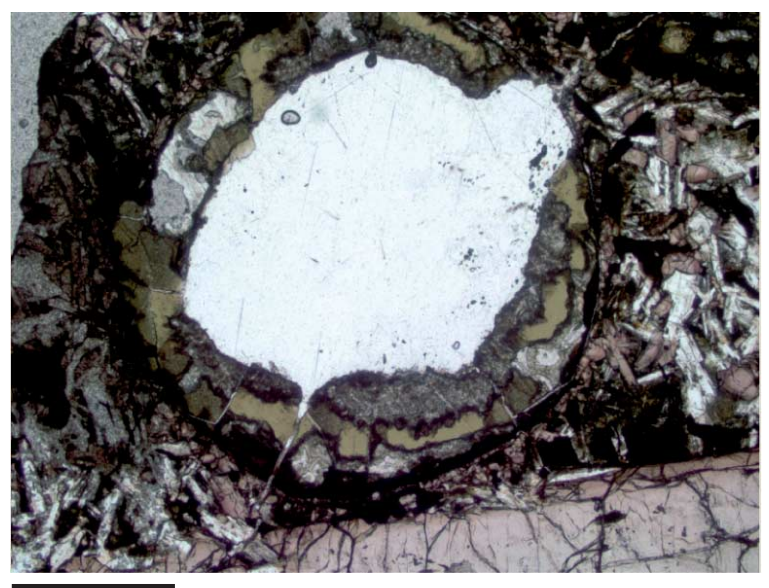

E

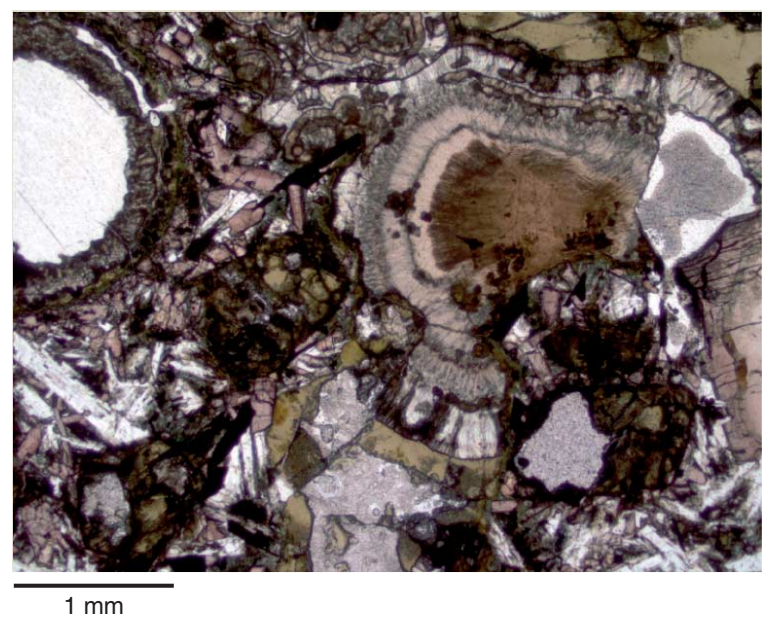

B

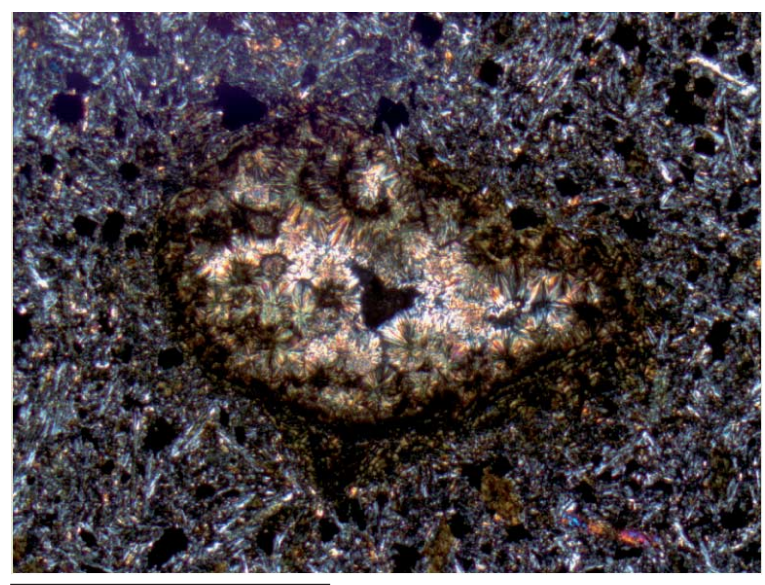

D

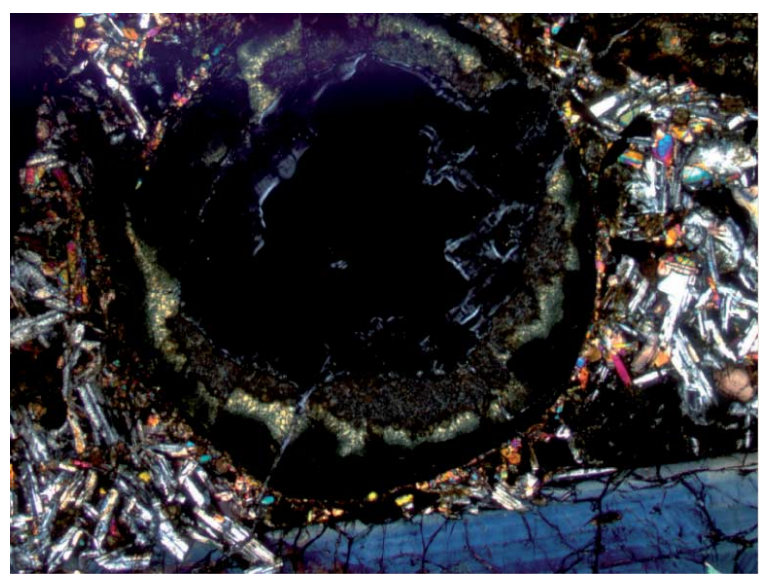

$1 \mathrm{~mm}$

$\mathbf{F}$

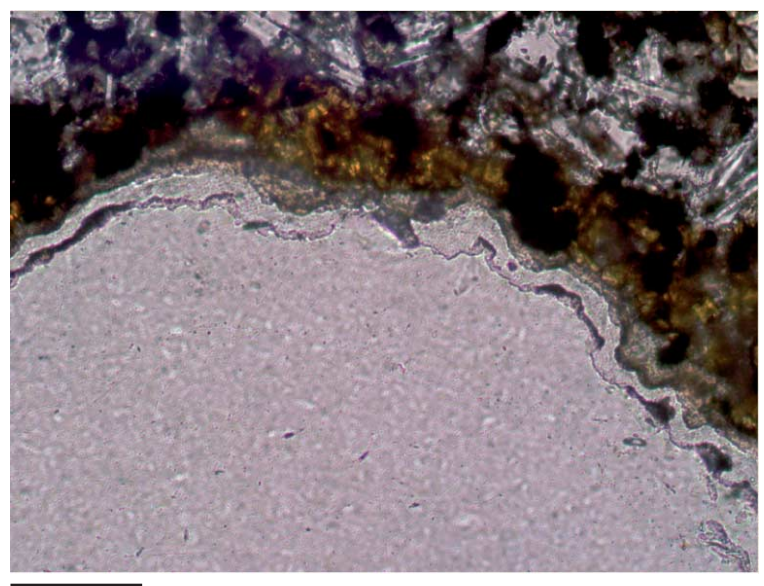

$0.1 \mathrm{~mm}$ 
Figure F31. Thin section photomicrographs of vesicles. A, B. High-sphericity rounded vesicle in sparsely phyric basalt, peperitic lava flow filled with zeolite (Sample 330-U1373A-9R-1, 17-20 cm; Thin Section 98): (A) planepolarized light, (B) crossed polars. C, D. Elongate subangular vesicle in aphyric basalt, peperitic lava flow partially filled with zeolite (Sample 330-U1373A-9R-2, 42-43 cm; Thin Section 99): (C) plane-polarized light, (D) crossed polars. E. Elongate subangular vesicle (aphyric basalt) partially filled with zeolite (Sample 330-U1373A7R-4, 11-13 cm; Thin Section 93; plane-polarized light). F. Vesicle in aphyric peperitic basalt, filled with goethite (Sample 330-U1373A-7R-4, 108-110 cm; Thin Section 95; plane-polarized light).

A

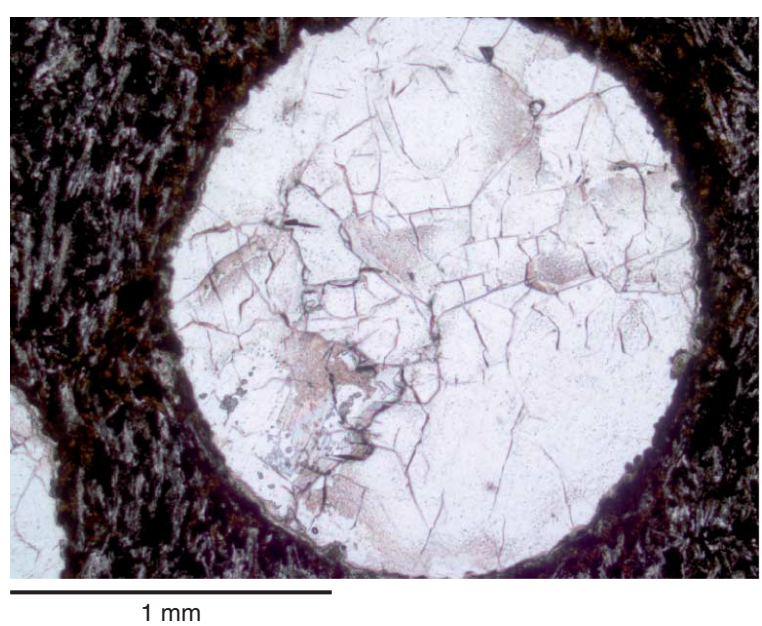

C

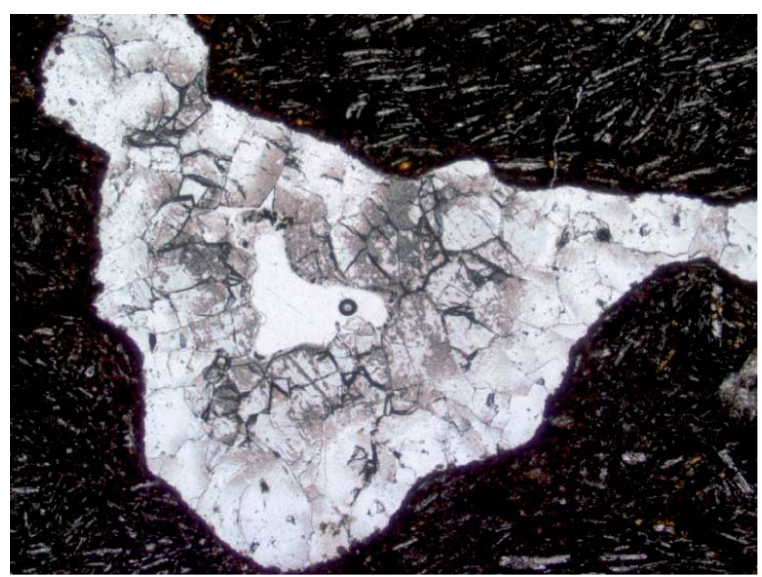

E

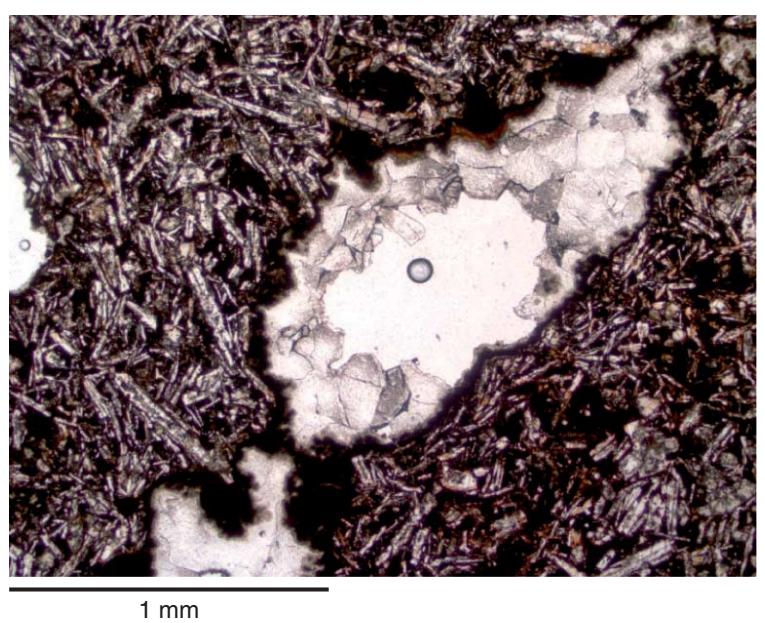

B

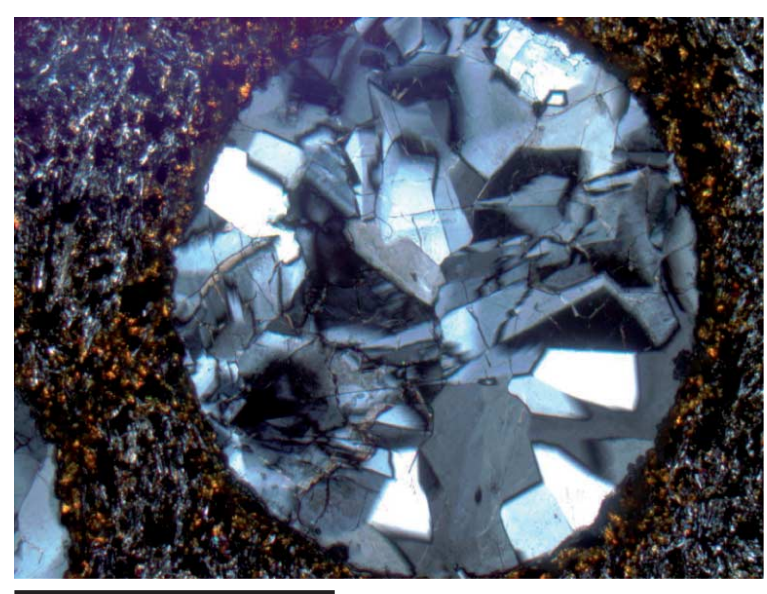

D

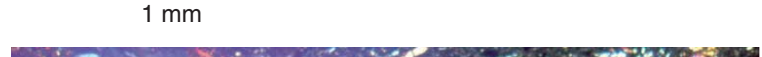

F
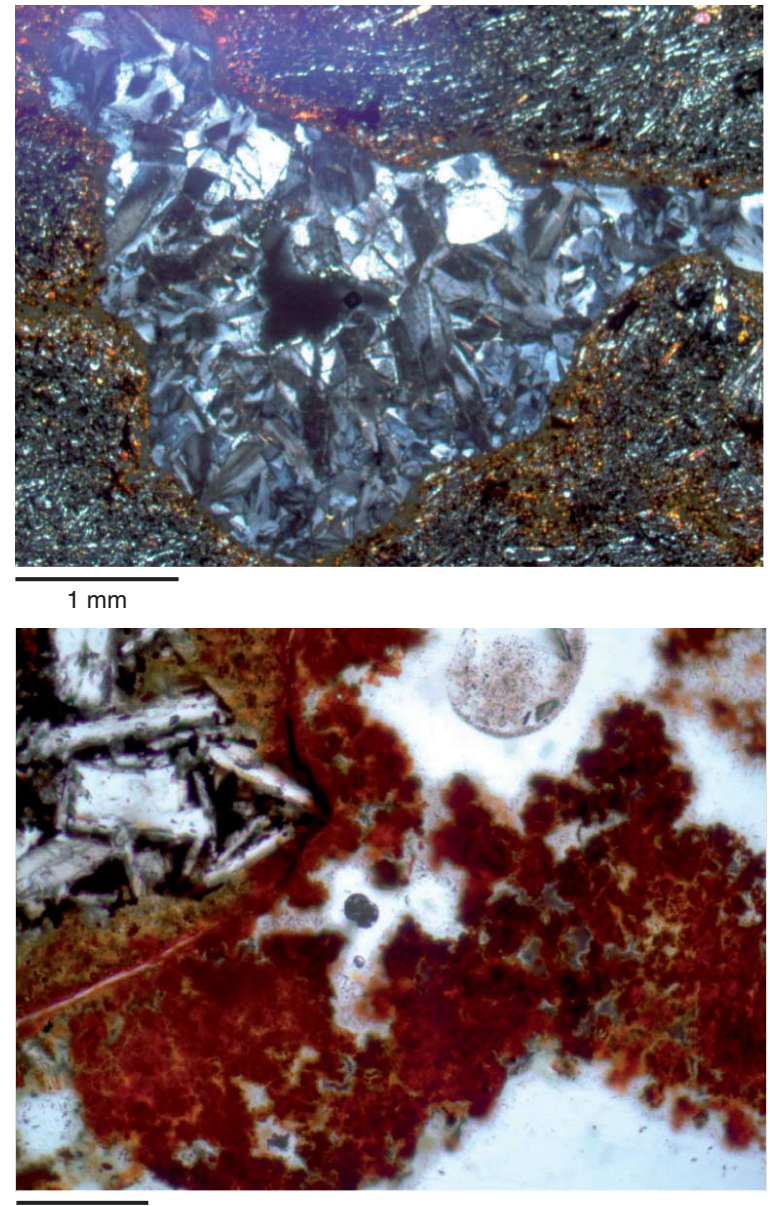

$0.1 \mathrm{~mm}$ 
Figure F32. Thin section photomicrographs of veins. A, B. Millimeter-thick vein in aphyric to moderately olivine-phyric basalt, volcanic breccia (A) filled with calcite and (B) vein crosscutting augite phenocryst (Sample 330-U1373A-2R-3, 133-135 cm; Thin Section 78; crossed polars). C. Millimeter-thick vein in massive, highly olivine-augite-phyric basalt filled with calcite and black clay (Sample 330-U1373A-7R-1, 84-86 cm; Thin Section 89; plane-polarized light). D. Composite millimeter-thick vein in aphyric basalt lava flow filled with calcite, iron oxides, and black and brown clay (Sample 330-U1373A-11R-2, 96-98 cm; Thin Section 104; planepolarized light).

A

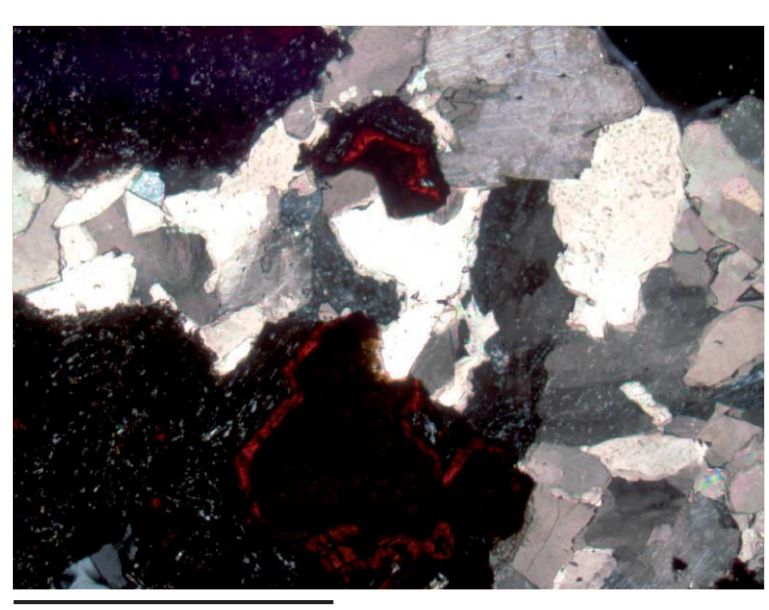

C

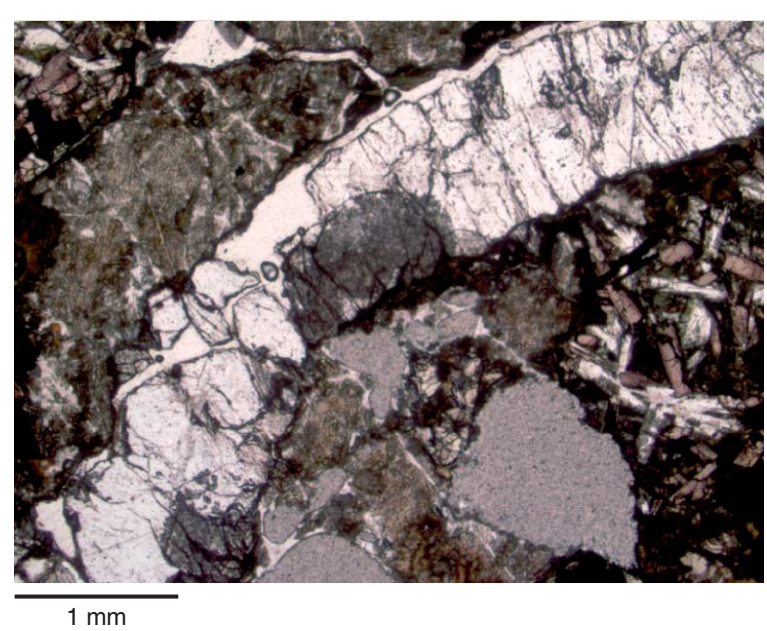

B

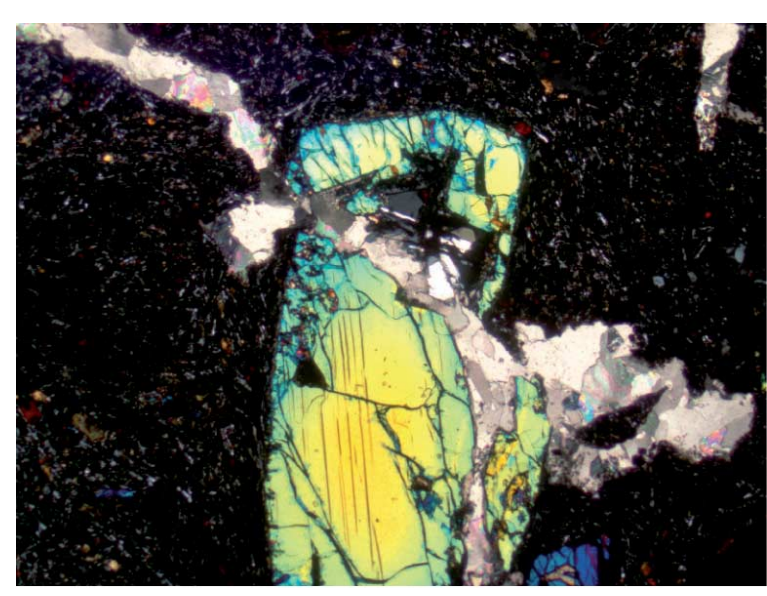

$1 \mathrm{~mm}$

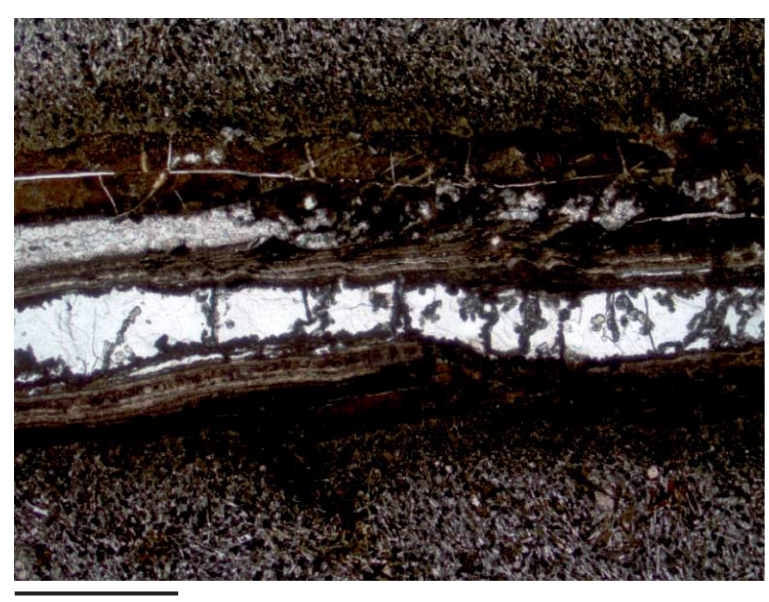

$1 \mathrm{~mm}$ 
Figure F33. Plot of downhole distribution of vein minerals for each alteration interval defined by the alteration petrology group. Symbols are located at center depth for each interval. Note the predominance of carbonates associated with black clay and Fe oxides/pyrite/chalcopyrite (composite and banded veins) from $\sim 40 \mathrm{mbsf}$ to bottom of Hole U1373A. Gray shading represents sedimentary units.

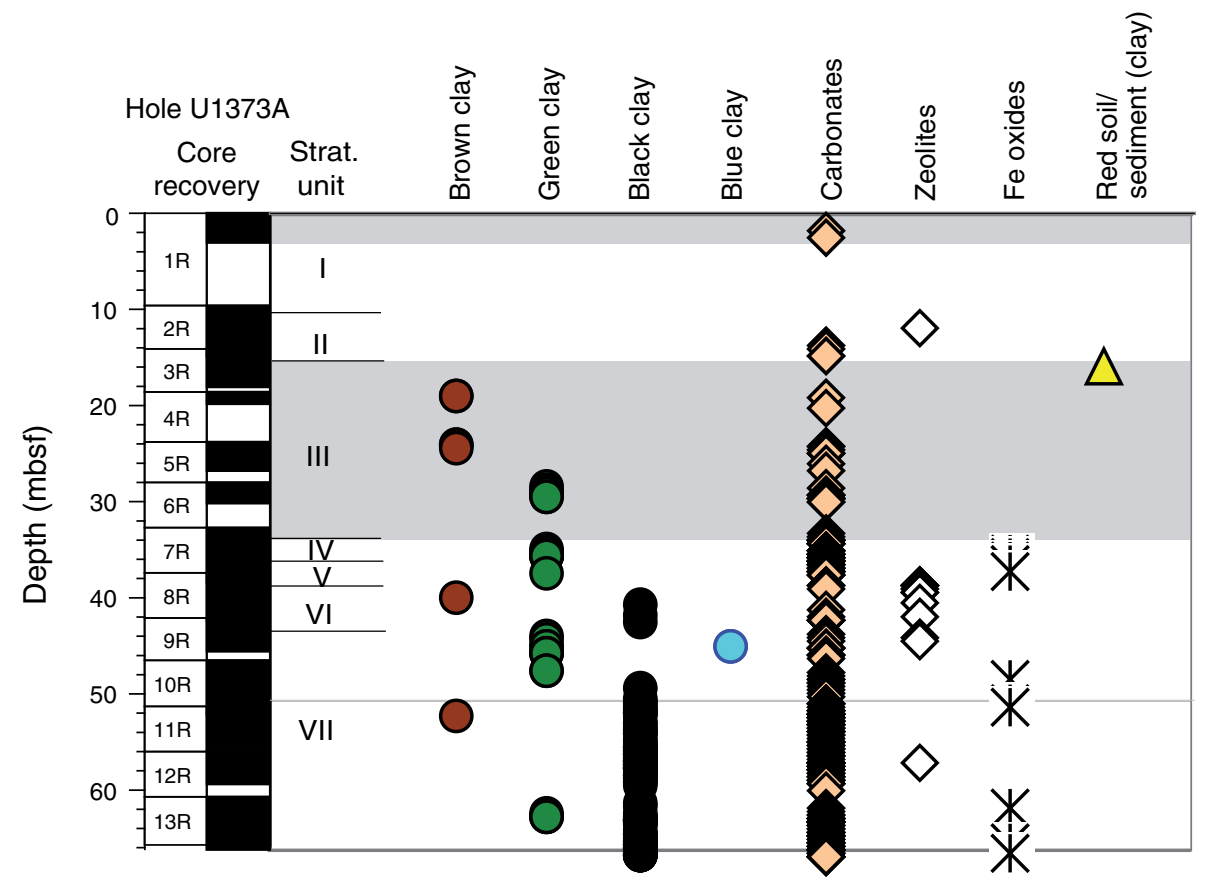


Figure F34. Number of structural features, Hole U1373A. Veins, vein networks, and fractures are the most abundant.

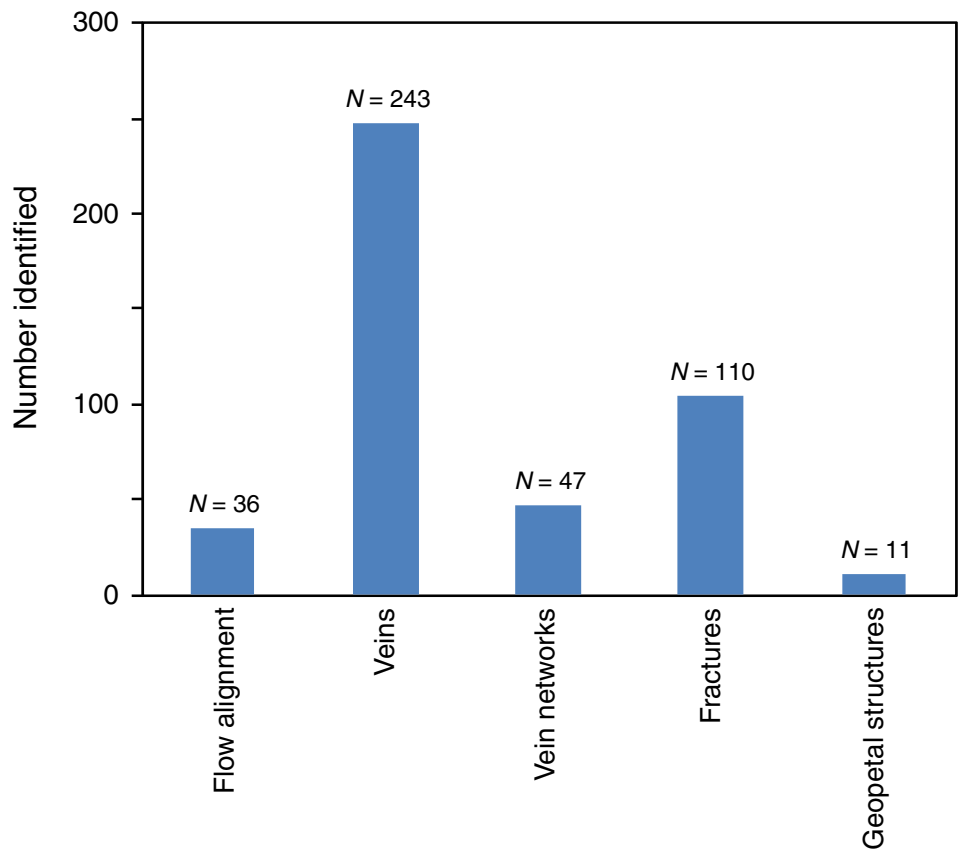


Figure F35. (A) Core recovery and stratigraphy of Hole U1373A, with (B, C) representative close-up photographs of geopetals. Vesicles and voids are filled with a pink micrite lower layer, with the remainder subsequently filled with pale gray/semitransparent calcite: (B) intervals 330-U1373A-1R-3, 62.5-68 cm (wet), and (C) 2R-1, 18.5-22.3 cm (wet). The pink micrite sediment is in the original horizontal sedimentary position, indicating no tilting of these rocks occurred since deposition. For explanation of lithology patterns, see Figure F11.

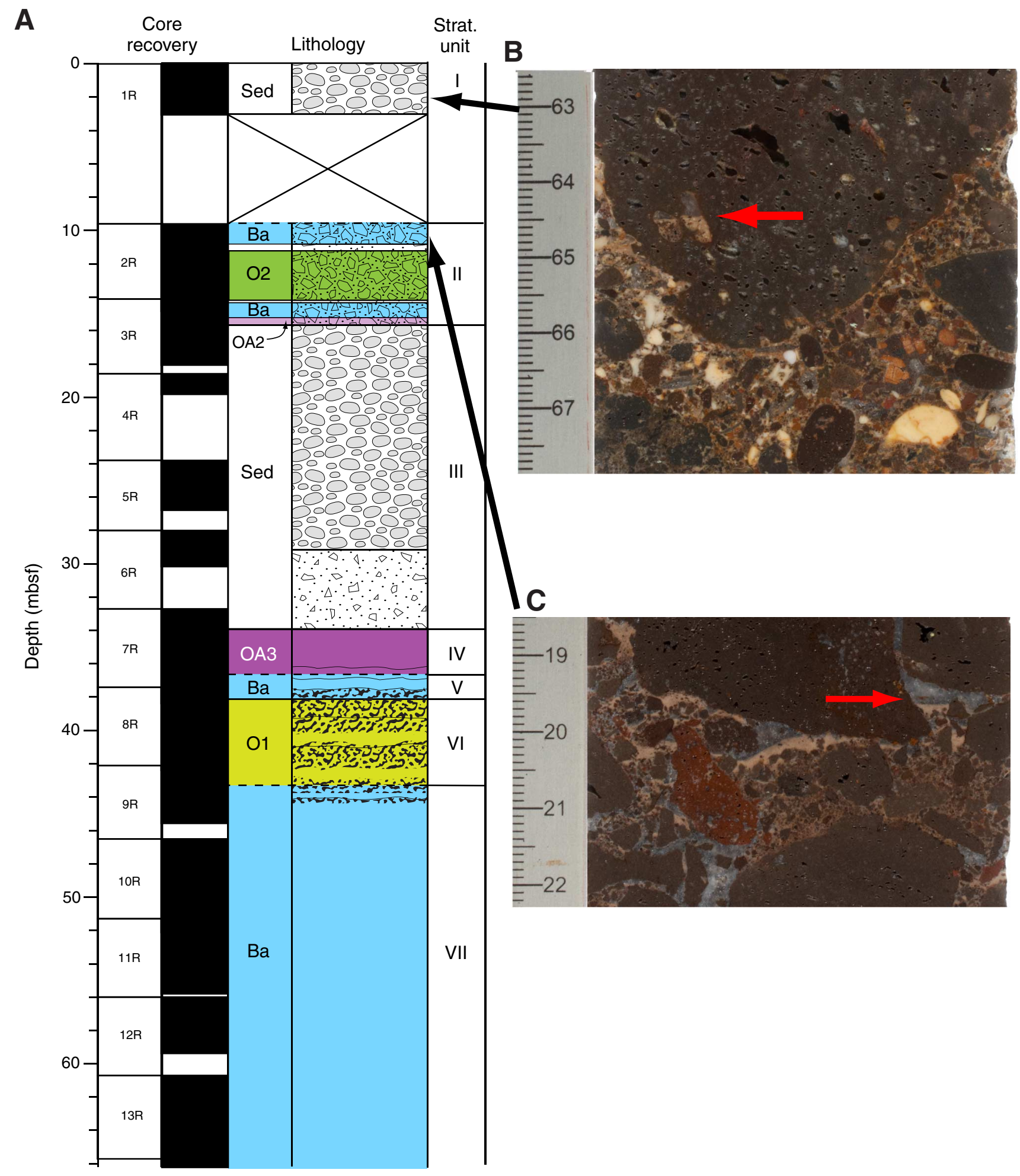


Figure F36. Distribution of fractures, Hole U1373A. Fractures are most common in the rheologically hard lava flows of Units IV and VII and are scarce to nonexistent in the volcaniclastic rocks. For explanation of lithology patterns, see Figure F11.

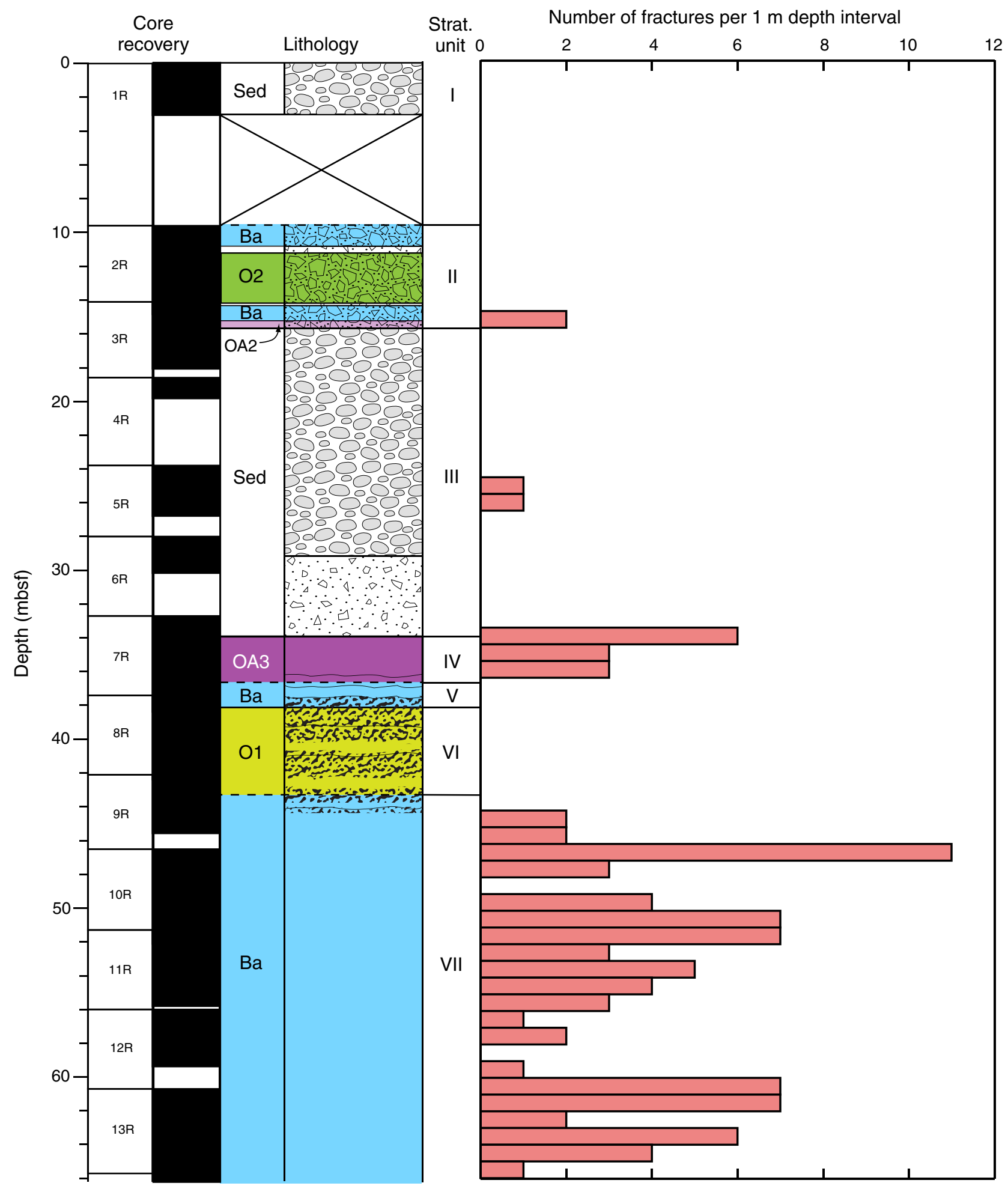


Figure F37. Distribution of veins, Hole U1373A. Veins are dominantly hosted in the hard lava flows of Units IV and VII, with relatively few occurrences in the rheologically weaker and more porous volcaniclastic units. For explanation of lithology patterns, see Figure F11.

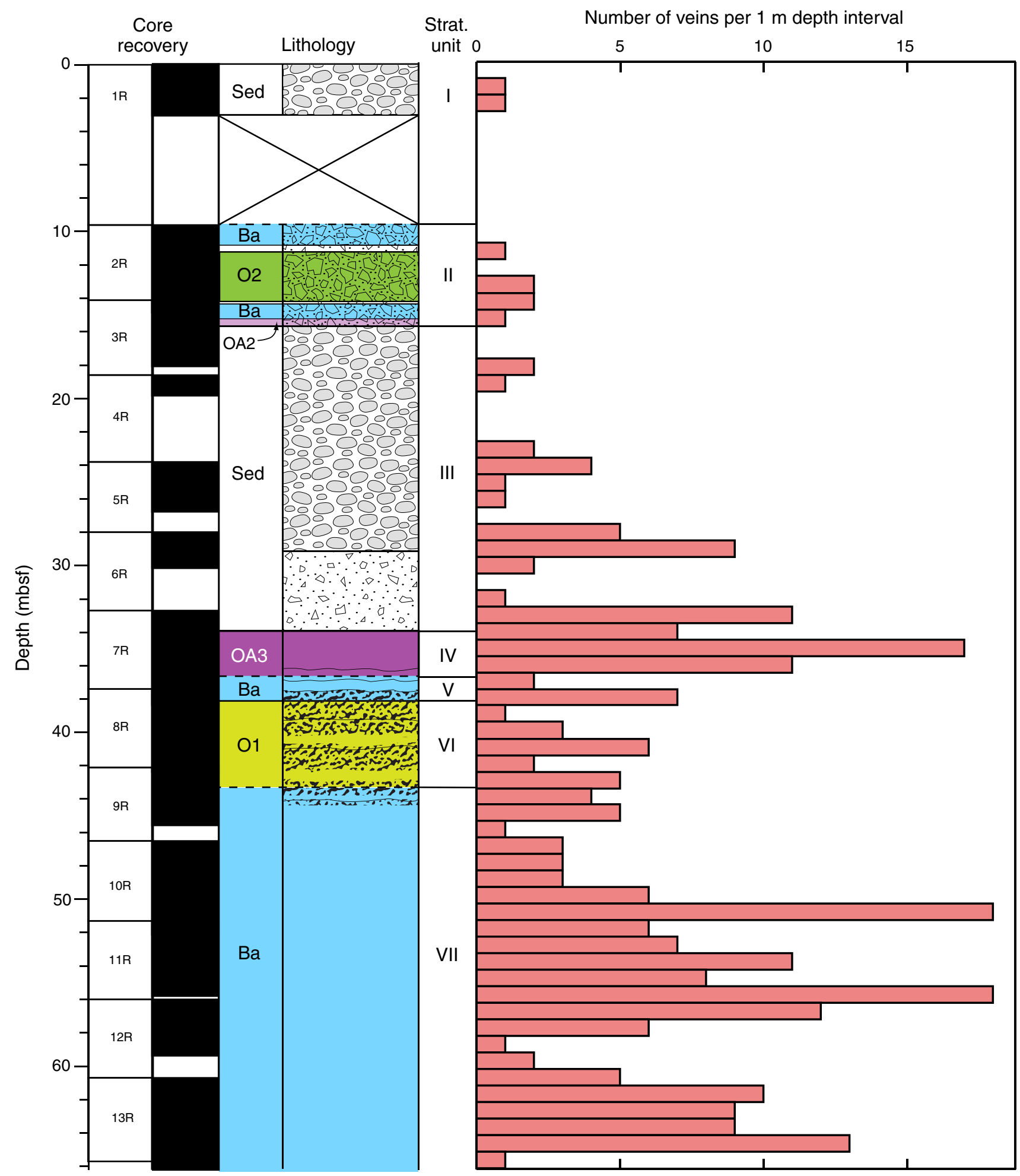


Figure F38. Thin section photomicrographs of flow alignment in Unit VII. All photomicrographs are oriented with the black arrow pointing to the top of the core. Plagioclase laths have a very steep alignment (red arrows), indicating lava flow in a near-vertical direction. A, B. Sample 330-U1373A-11R-2W, 96-98 cm (Thin Section 104). C, D. Sample 330-U1373A-13R-1W, 32-36 cm (Thin Section 105). E, F. Sample 330-U1373A-13R-3W, 10$12 \mathrm{~cm}$ (Thin Section 106). A, C, and E are under plane-polarized light; B, D, and F are with crossed polars.

A

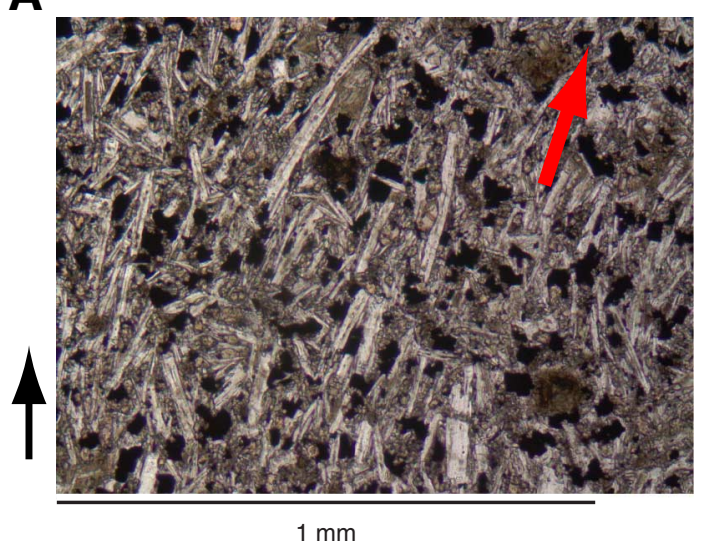

C

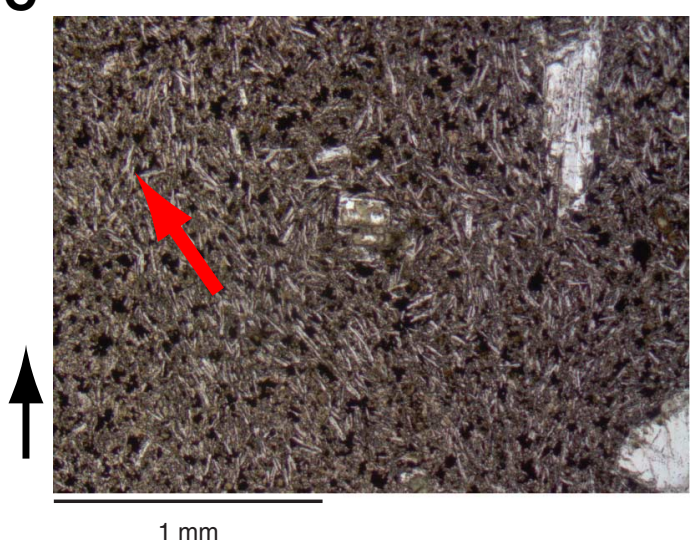

$\mathbf{E}$

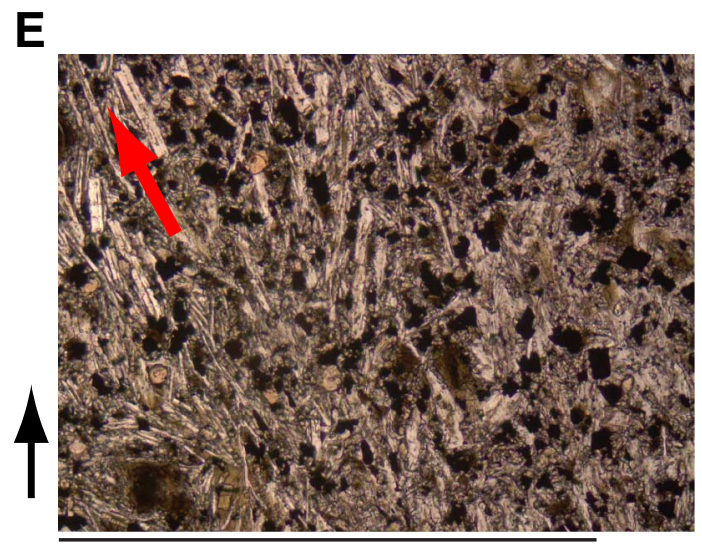

$1 \mathrm{~mm}$
B

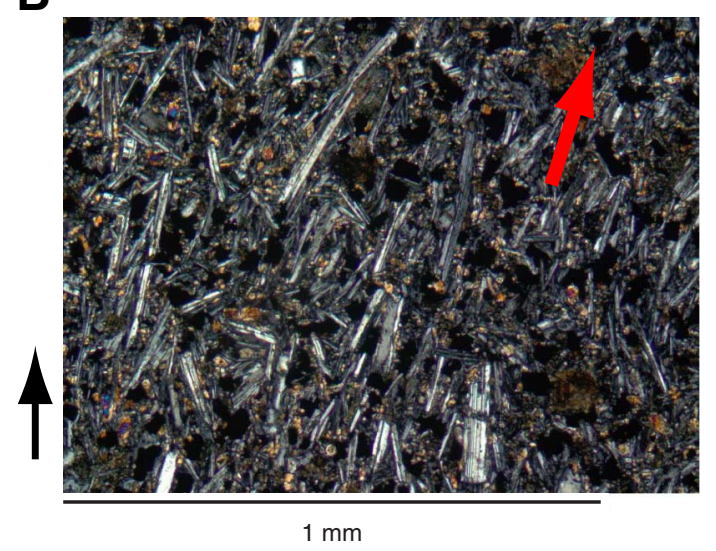

D

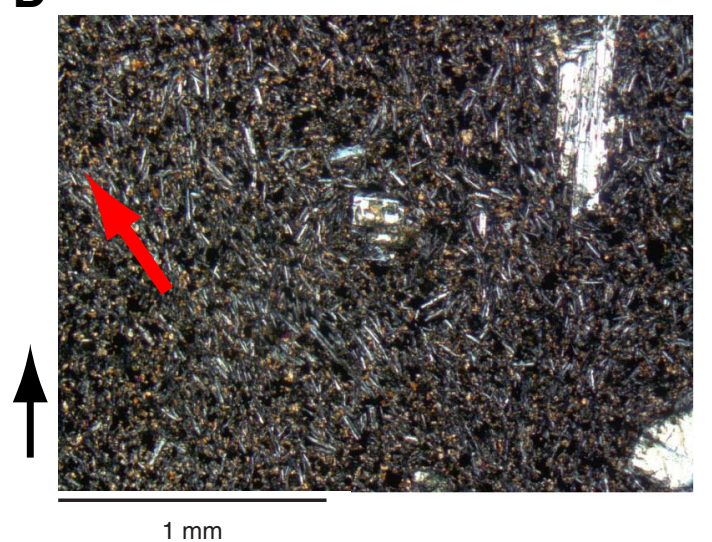

F

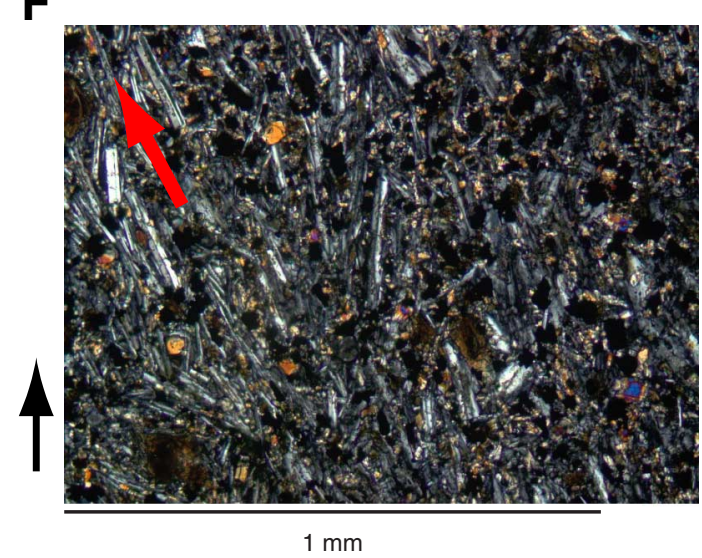


Figure F39. Dip angles of fractures, veins, and magmatic foliations in igneous basement, relative to core reference frame, Hole U1373A. Fractures in igneous basement are mostly steeply dipping $\left(70^{\circ}-75^{\circ}\right)$, with a conjugate set at shallow dips $\left(15^{\circ}-20^{\circ}\right)$. There are two main groups of veins, one with shallow dips $\left(\sim 10^{\circ}-40^{\circ}\right)$ and another with dips ranging from $50^{\circ}$ to $75^{\circ}$. Dip angles for magmatic foliation are highly bimodal. Near-vertical dips (corresponding to near-vertical flow in Unit VII) are dominant, with the remainder of shallow dips corresponding to rocks with shallow to moderate flow alignment.
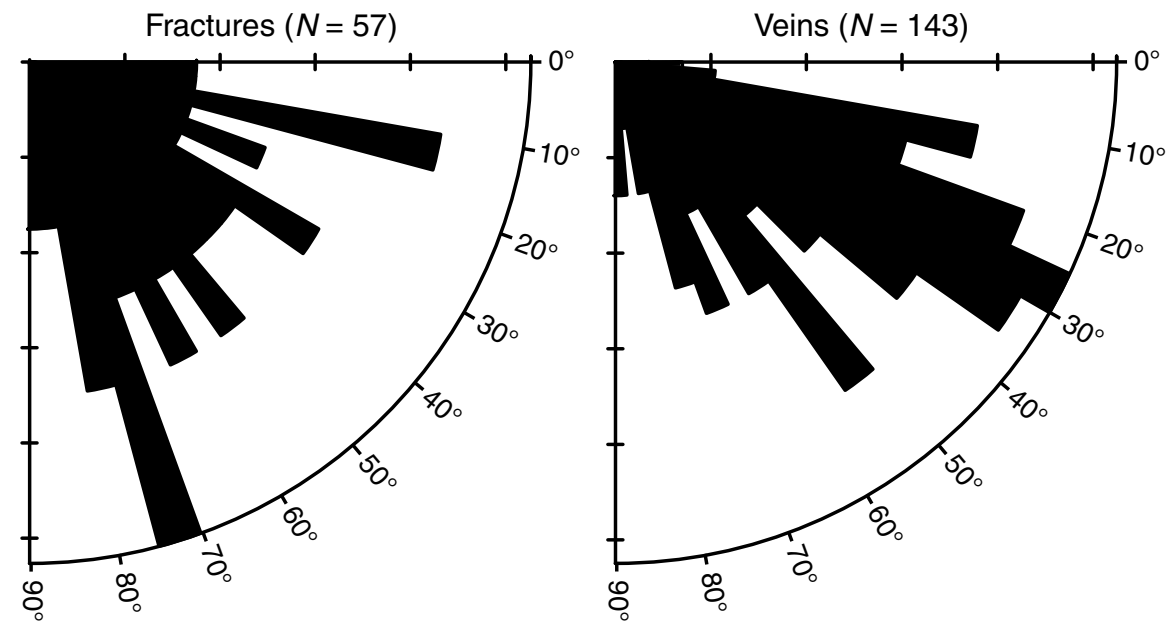

Magmatic foliation $(N=24)$

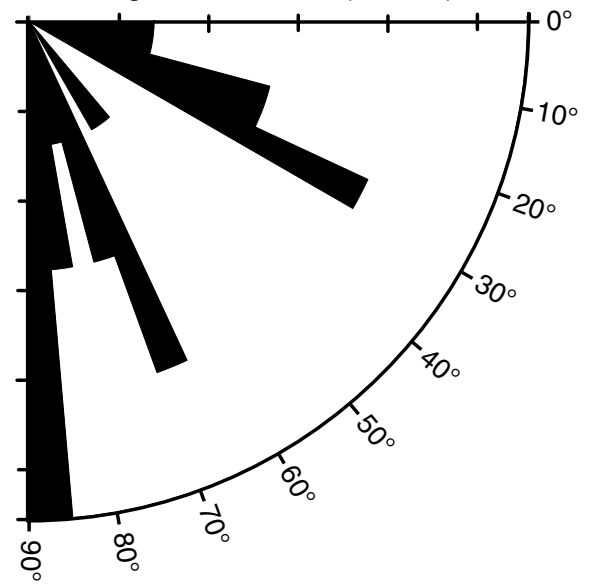


Figure F40. Total alkalis vs. silica for Sites U1372 and U1373, with Le Maitre et al.'s (1989) classification of volcanic rock types. The dashed line divides data for tholeiitic and alkalic rocks of Hawaii (Macdonald and Katsura, 1964; Macdonald, 1968). Expedition 330 data are normalized to $100 \mathrm{wt} \%$ totals. Shown for comparison are data for dredge samples from the length of the Louisville Seamount Trail (only data for dredge samples with LOI $<6$ wt $\%$ are included; data of Hawkins et al., 1987; Vanderkluysen et al., 2007; Beier et al., 2011). Also shown are fields for the southern East Pacific Rise (EPR; data of Sinton et al., 1991; Bach et al., 1994; Mahoney et al., 1994), and Ontong Java Plateau (OJP; data of Tejada et al., 1996, 2002; Fitton and Godard, 2004).

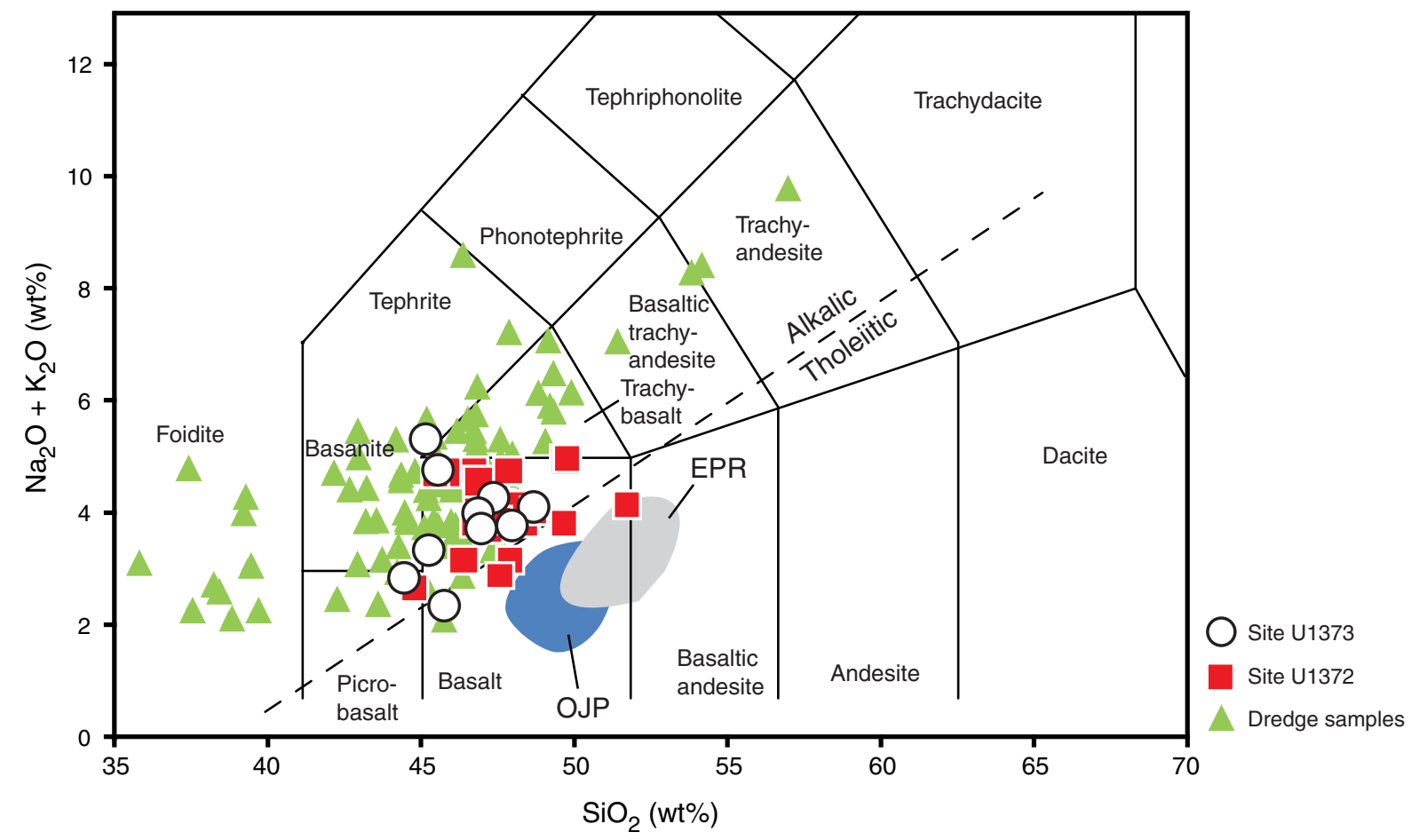


Figure F41. $\mathrm{MgO}$ vs. (A) $\mathrm{Al}_{2} \mathrm{O}_{3},\left(\right.$ B) $\mathrm{Na}_{2} \mathrm{O}$, and (C) $\mathrm{CaO} / \mathrm{Al}_{2} \mathrm{O}_{3}$ for Sites U1372 and U1373. Expedition 330 data are normalized to $100 \mathrm{wt} \%$ totals. Data for dredge samples include only samples with LOI $<6 \mathrm{wt} \%$ (data of Hawkins et al., 1987; Vanderkluysen et al., 2007; Beier et al., 2011). Fields for several Hawaiian volcanoes are shown. "Hawaii shield" fields are for Mauna Kea (blue line), Mauna Loa (green line), and Kilauea (red line) (data of Lipman et al., 1990; Frey et al., 1991; Moore and Clague, 1992; Clague et al., 1995; Rhodes and Hart, 1995; Garcia et al., 2003). "Hawaii postshield" fields include Lapahoehoe and Hamakua lavas (data of Frey et al., 1990; West et al., 1988). Also shown are fields for the southern East Pacific Rise (EPR; data of Sinton et al., 1991; Bach et al., 1994; Mahoney et al., 1994) and Ontong Java Plateau (OJP; data of Tejada et al., 1996, 2002; Fitton and Godard, 2004).

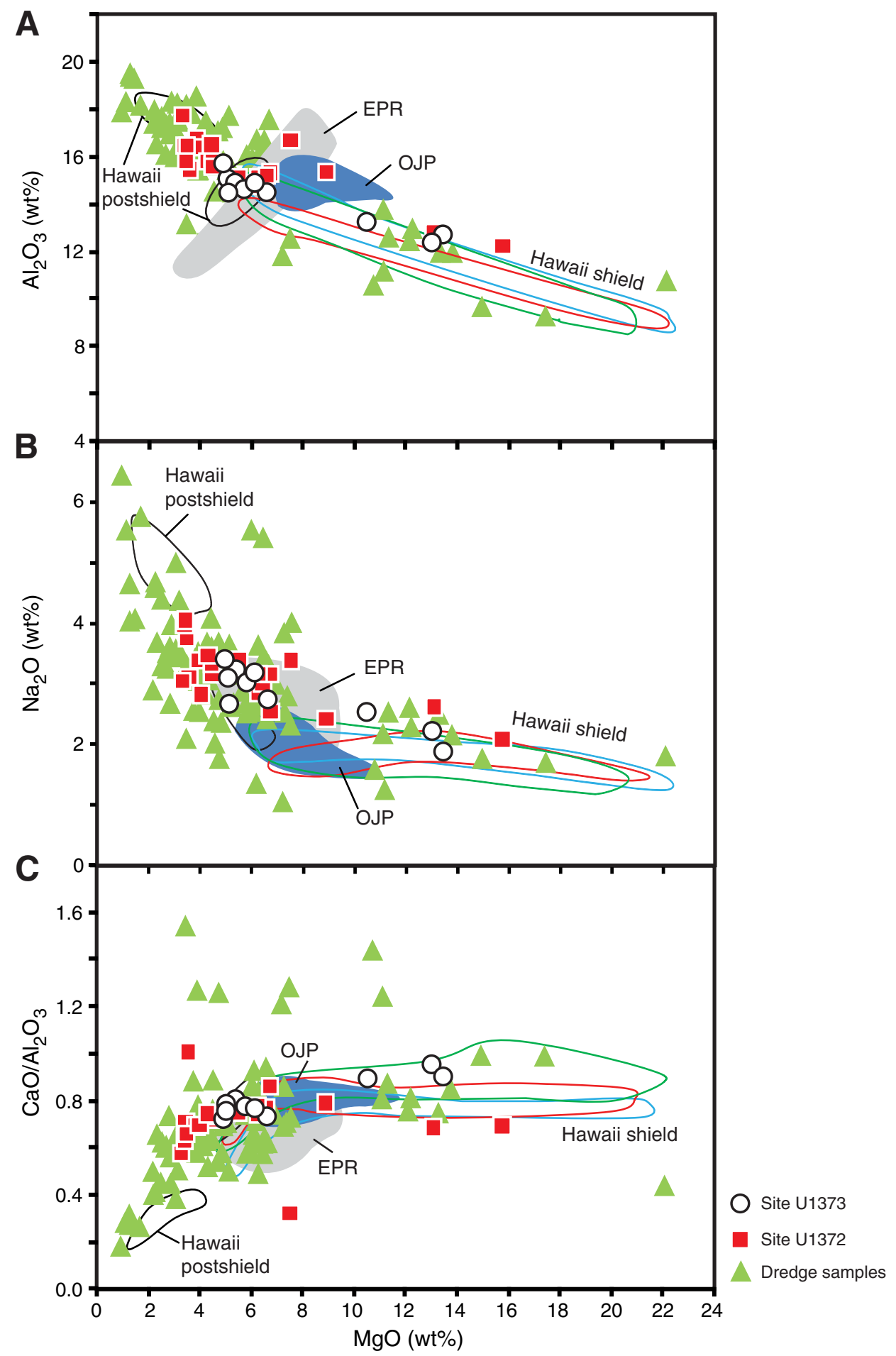


Figure F42. $\mathrm{TiO}_{2}$ vs. (A) $\mathrm{P}_{2} \mathrm{O}_{5},($ B) $\mathrm{Y},($ C) $\mathrm{Sr}$, and (D) Ba for Sites U1372 and U1373. Note that Expedition 330 major element data are normalized to $100 \mathrm{wt} \%$ totals. Data for dredge samples from the Louisville Seamount Trail include only samples with LOI < $6 \mathrm{wt} \%$ (data of Hawkins et al., 1987; Vanderkluysen et al., 2007; Beier et al., 2011). Fields for several Hawaiian volcanoes are shown. "Hawaii shield" fields are for Mauna Kea (blue line), Mauna Loa (green line), and Kilauea (red line) (data of Lipman et al., 1990; Frey et al., 1991; Moore and Clague, 1992; Clague et al., 1995; Rhodes and Hart, 1995; Garcia et al., 2003). "Hawaii postshield" fields include Lapahoehoe and Hamakua lavas (data of Frey et al., 1990; West et al., 1988). Also shown are fields for the southern East Pacific Rise (EPR; data of Sinton et al., 1991; Bach et al., 1994; Mahoney et al., 1994), and Ontong Java Plateau (OJP; data of Tejada et al., 1996, 2002; Fitton and Godard, 2004).
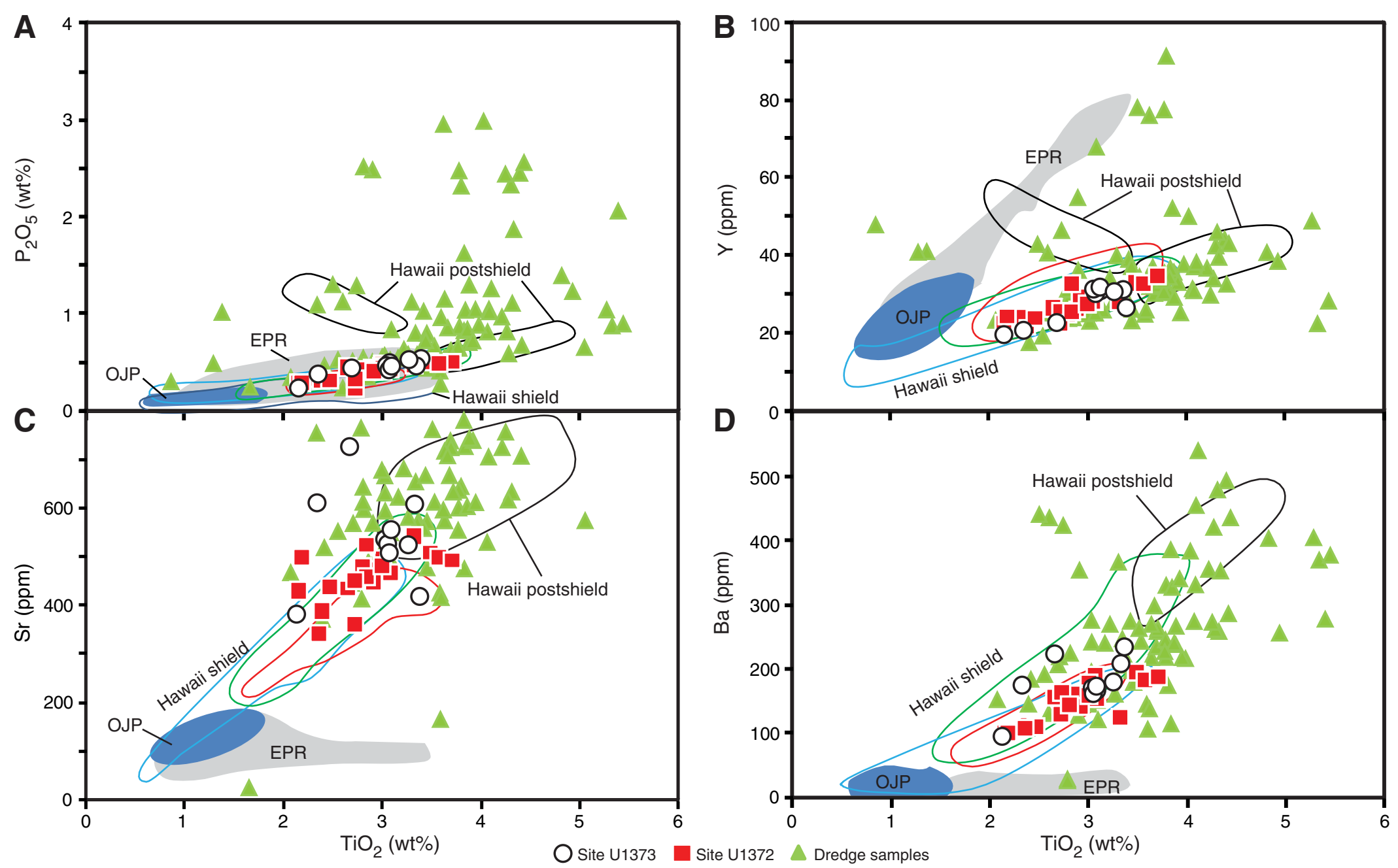
Figure F43. Downhole variation of (A) Mg\#, (B) Ni, (C) $\mathrm{Fe}_{2} \mathrm{O}_{3}{ }^{\top}$, and (D) $\mathrm{Zr} / \mathrm{Ti}$ for Site U1373 basalts. Dashed lines mark stratigraphic unit boundaries. See Figure F11 for explanation of stratigraphy. Note that Expedition 330 major element data are normalized to $100 \mathrm{wt} \%$ totals.

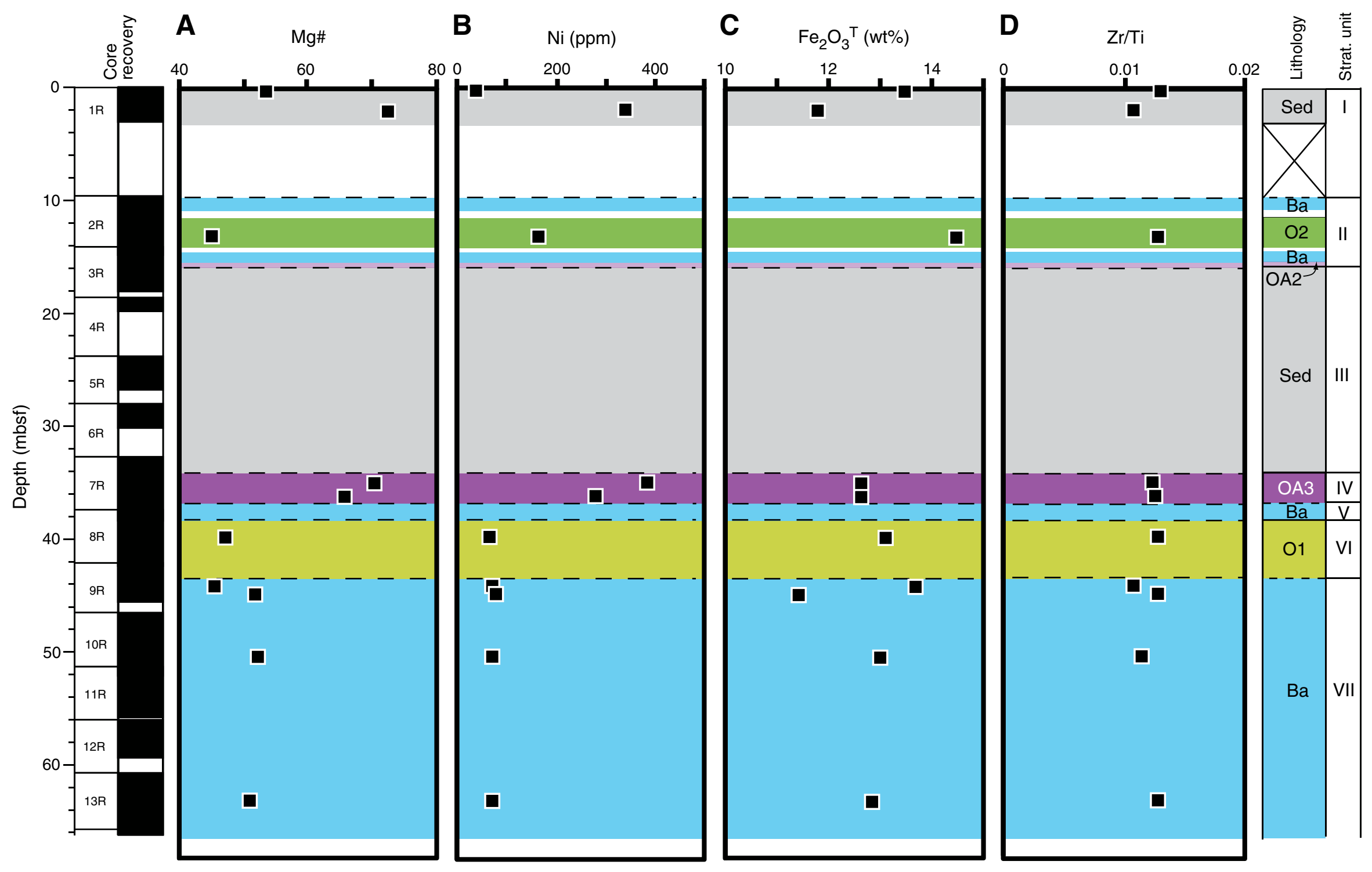


Figure F44. Depth profiles of magnetic susceptibility, Hole U1373A. Core recovery and stratigraphic columns are shown for reference. For explanation of stratigraphy, see Figure F11.

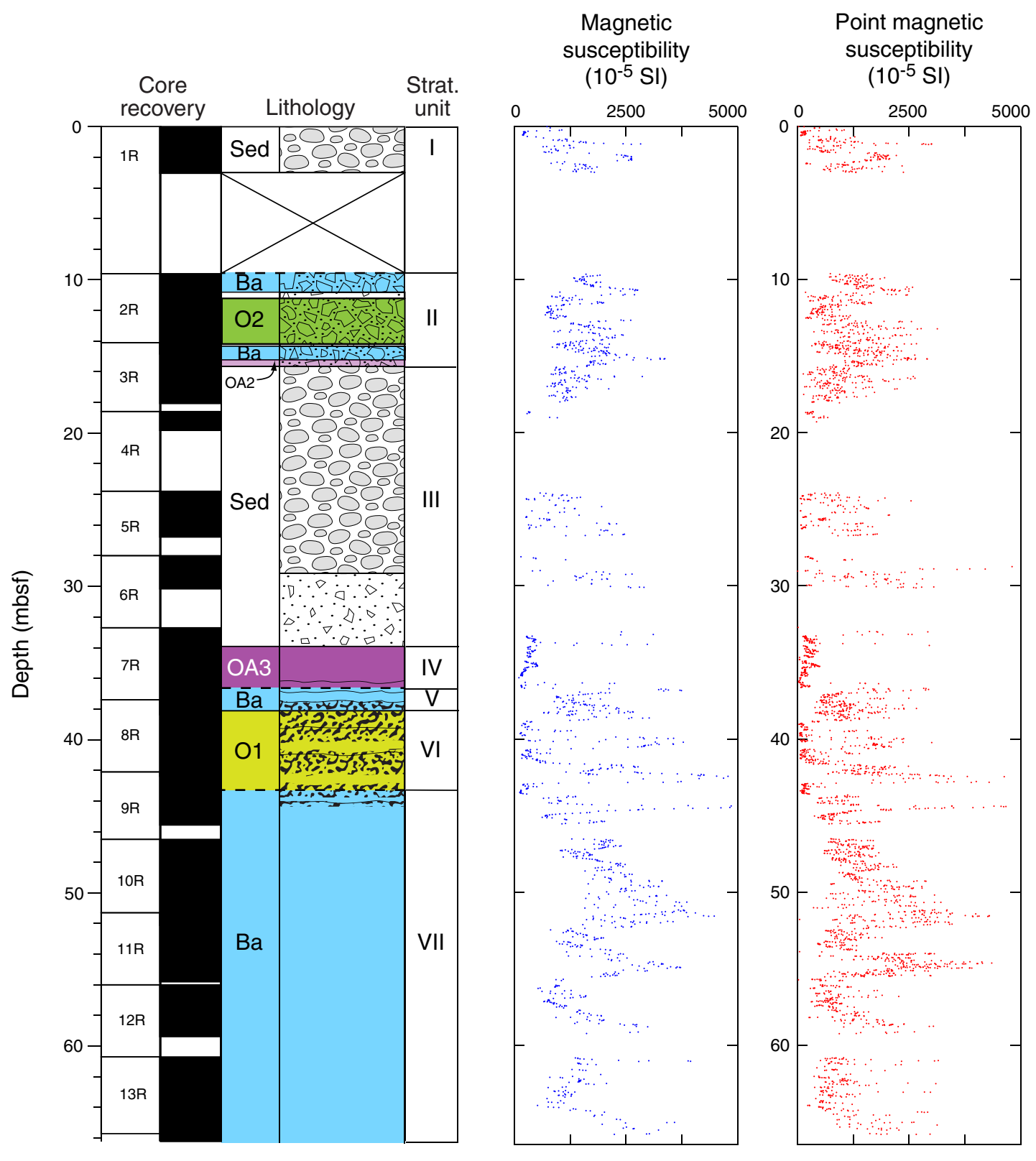


Figure F45. Close-up depth profiles of magnetic susceptibility for interval of 35-50 mbsf, Hole U1373A. Oscillations from high to low magnetic susceptibility correlate with boundaries between peperitic and more massive lava flows. Arrows mark two peaks in magnetic susceptibility in Unit VI and one peak near the top of Unit VII at $44.5 \mathrm{mbsf}$. Solid lines in magnetic susceptibility plots = stratigraphic unit boundaries, dashed lines = lithologic unit boundaries in stratigraphic Units VI and VII.

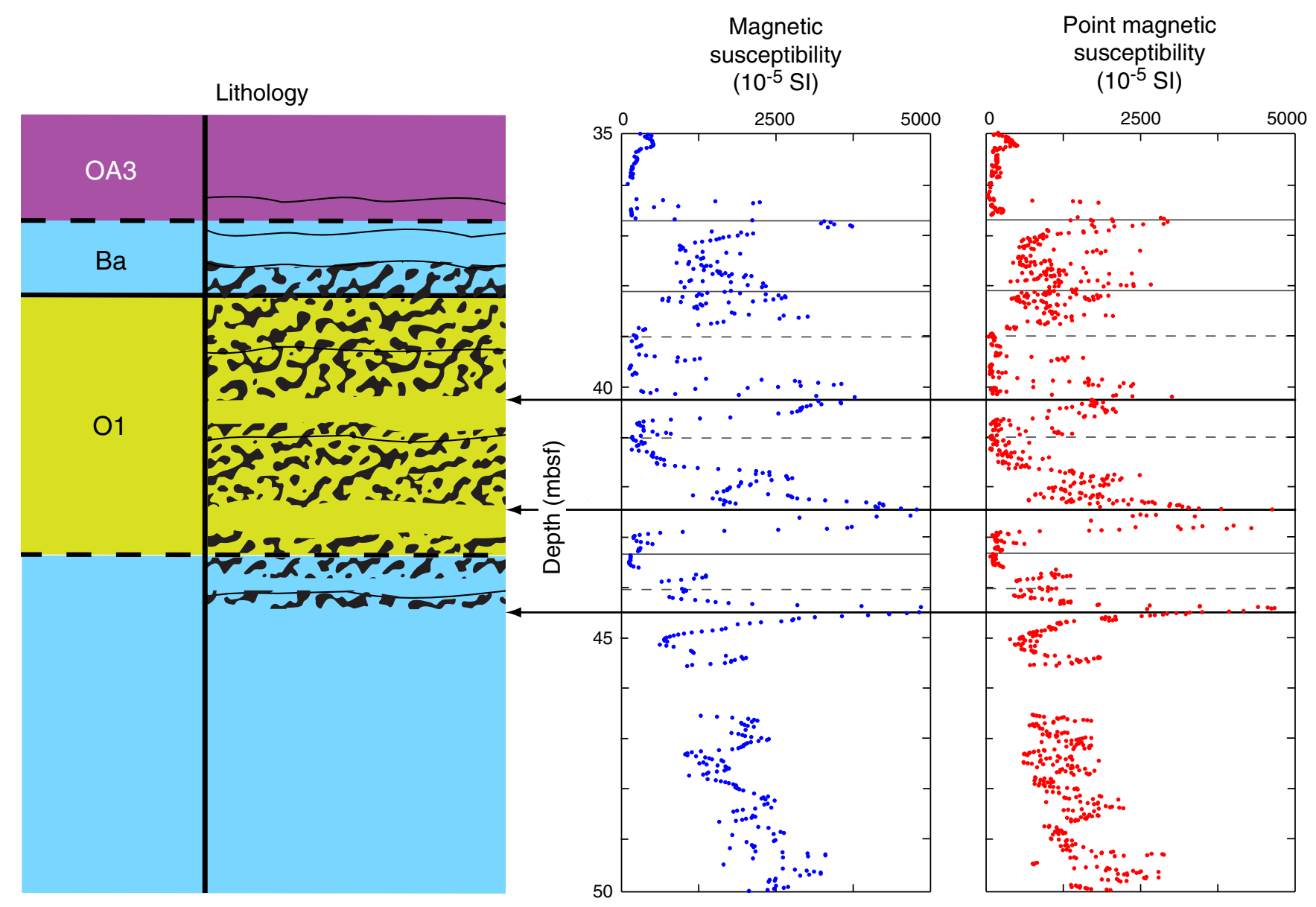


Figure F46. Thin section photomicrographs of (A) Sample 330-U1373A-9R-2, 113-115 cm (Thin Section 101) and (B) Sample 9R-3, 39-41cm (Thin Section 102). Images were taken in reflected light and show a marked contrast in the amount and habit of magnetite (grains with light color).

A

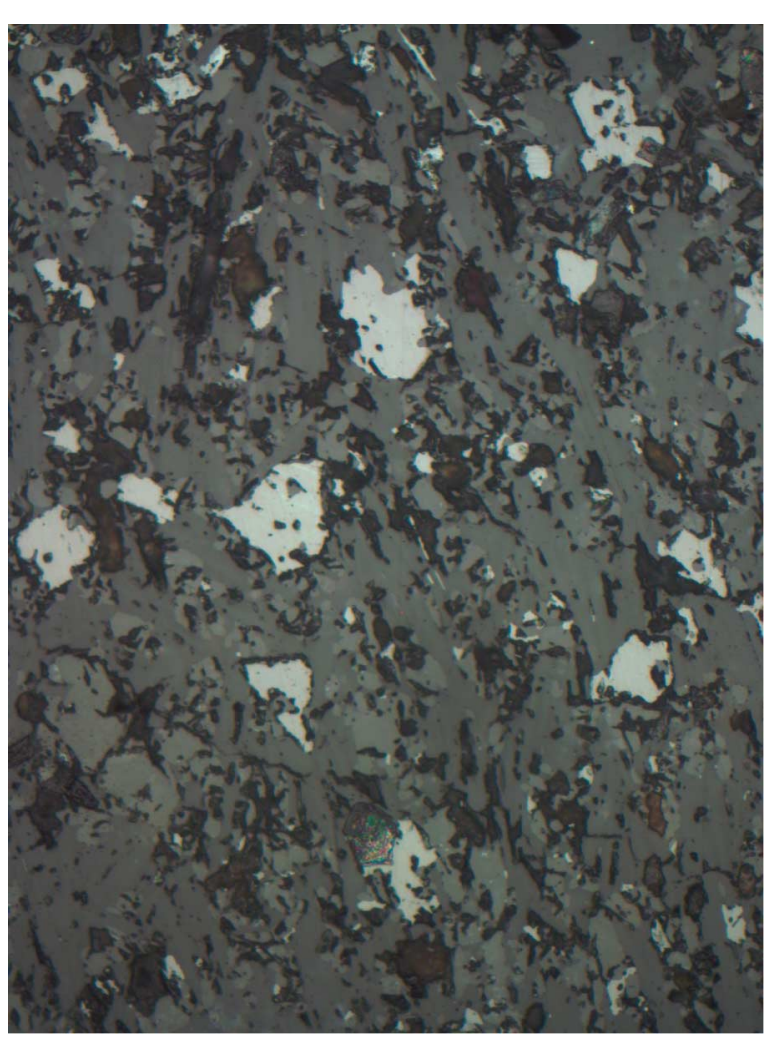

$0.1 \mathrm{~mm}$
B

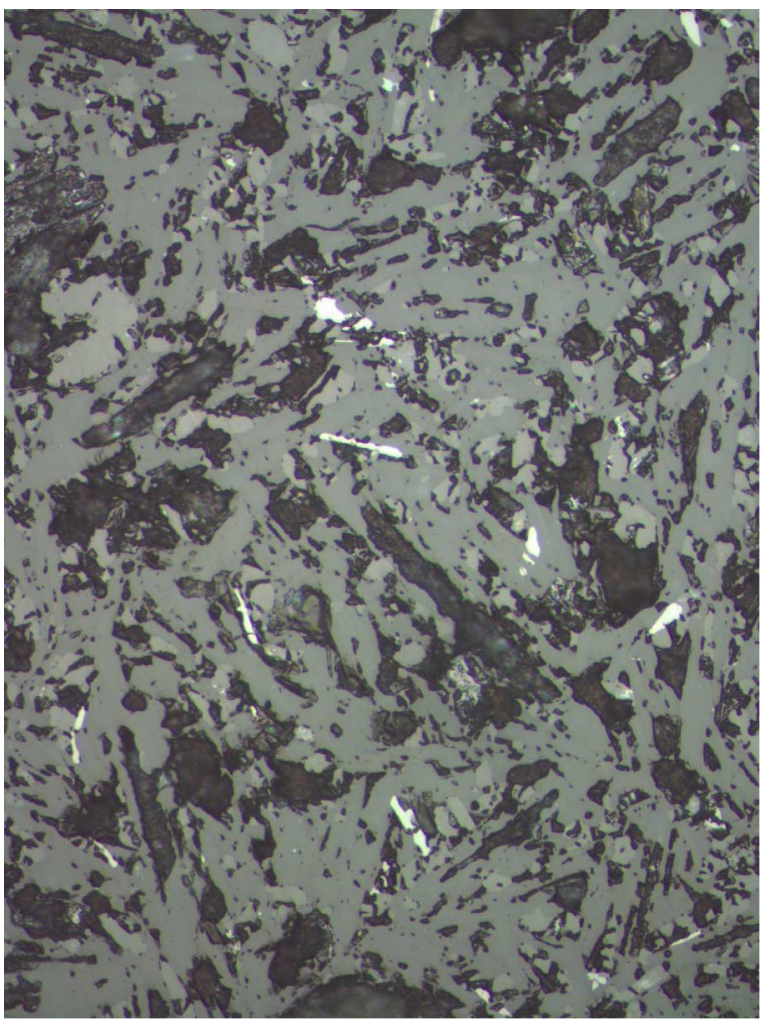

$0.1 \mathrm{~mm}$ 
Figure F47. Depth profiles of bulk density and discrete $P$-wave velocity for Hole U1373A, shown with corresponding stratigraphic column. Bulk density: red squares $=$ moisture and density Method $\mathrm{C}$ measurements taken on discrete samples, black dots $=$ GRA bulk density. $P$-wave velocity: blue $=x$-axis (normal to the splitcore surface), red $=y$-axis (parallel to the split-core surface), green $=z$-axis (downcore). For explanation of stratigraphy, see Figure F11.

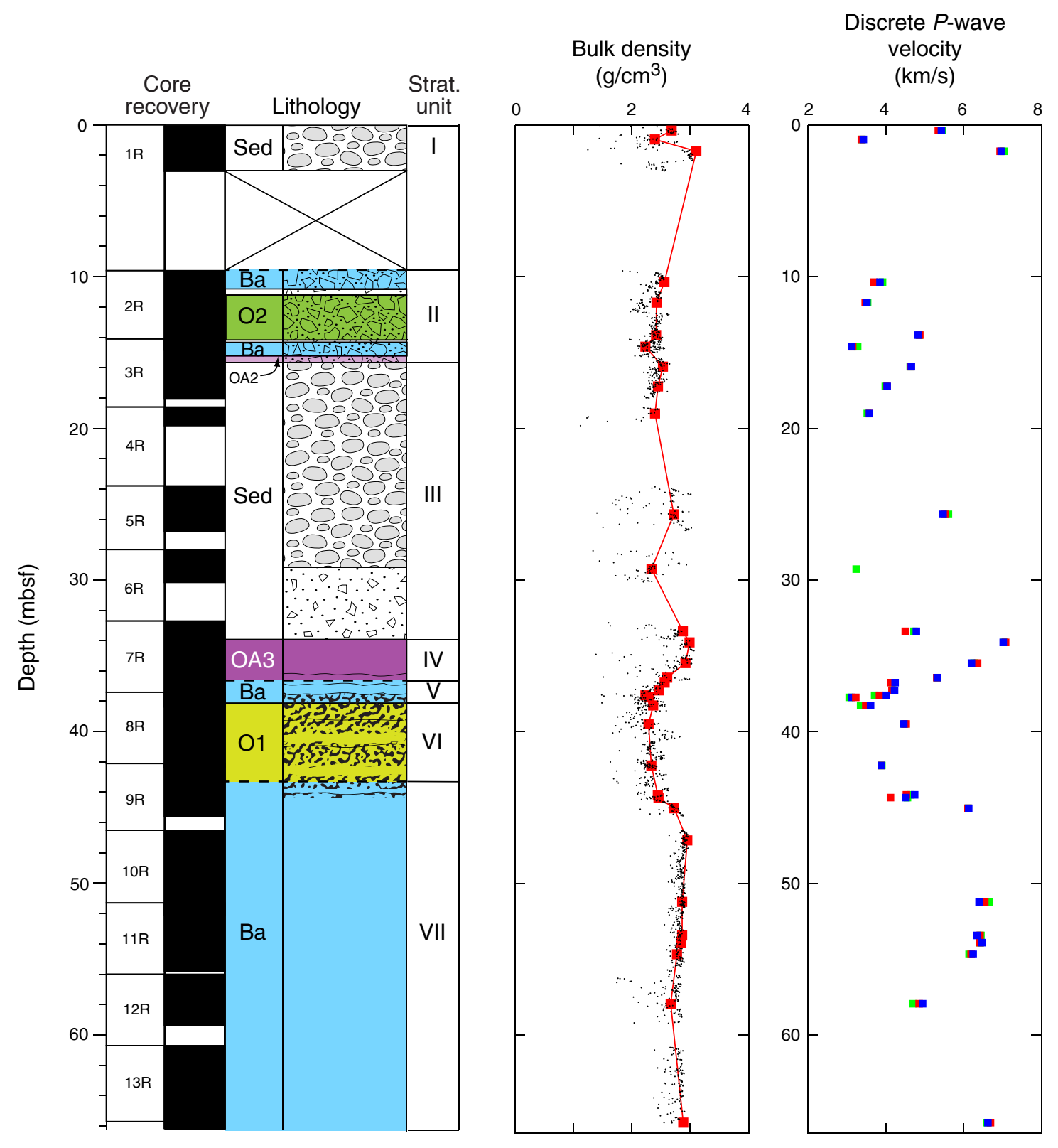


Figure F48. Depth profile of natural gamma radiation (NGR), Hole U1373A. Stratigraphic column is shown for reference. For explanation of stratigraphy, see Figure F11.

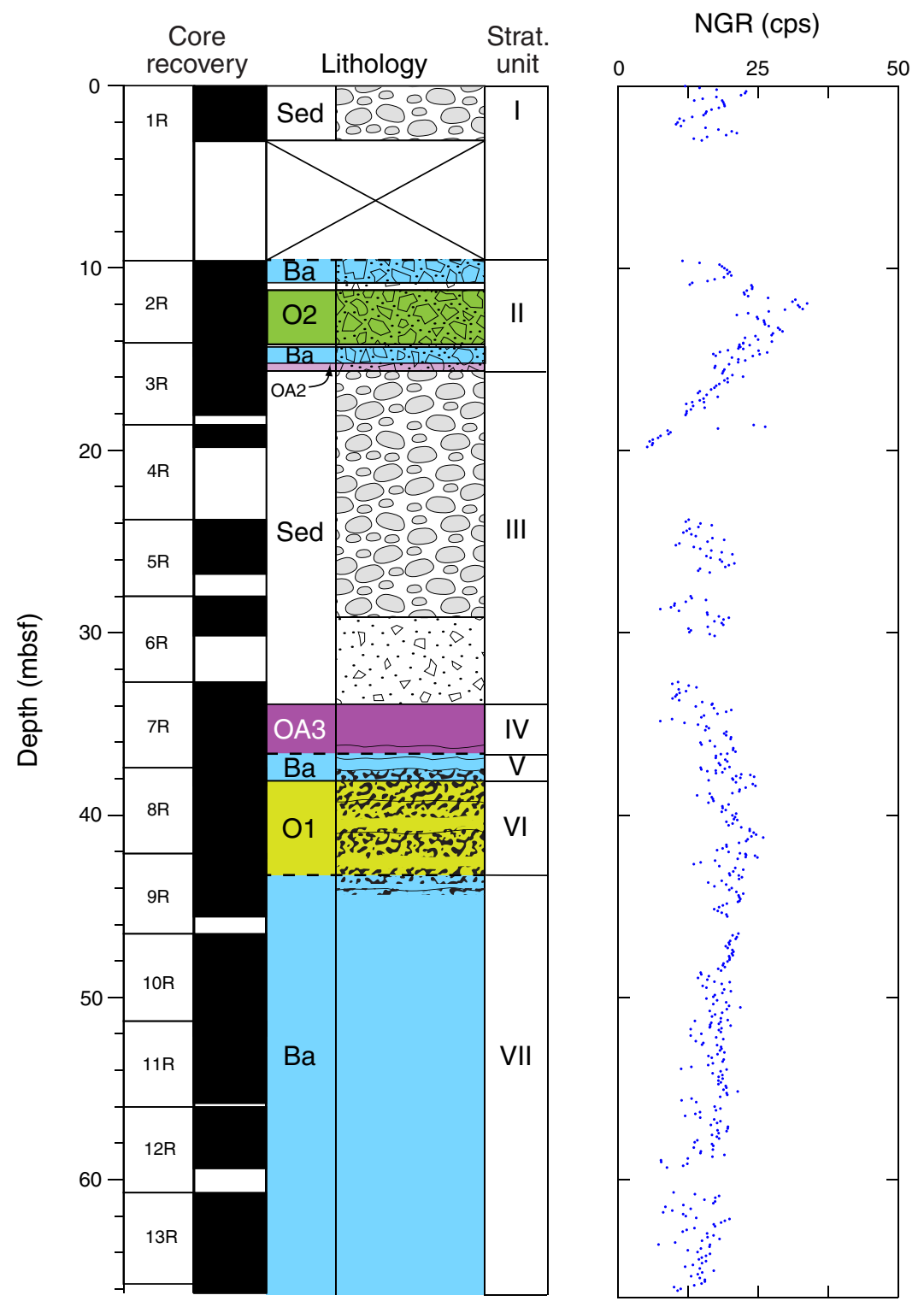


Figure F49. Depth profile of color reflectance parameters $L^{*}, a^{*}$, and $b^{*}$, Hole U1373A. Higher $L^{*}$ values indicate lighter colors. $\mathrm{a}^{*}=$ relative color position between red (positive) and green (negative), $\mathrm{b}^{*}=$ relative color position between yellow (positive) and blue (negative). Stratigraphic column is shown for reference. For explanation of stratigraphy, see Figure F11.
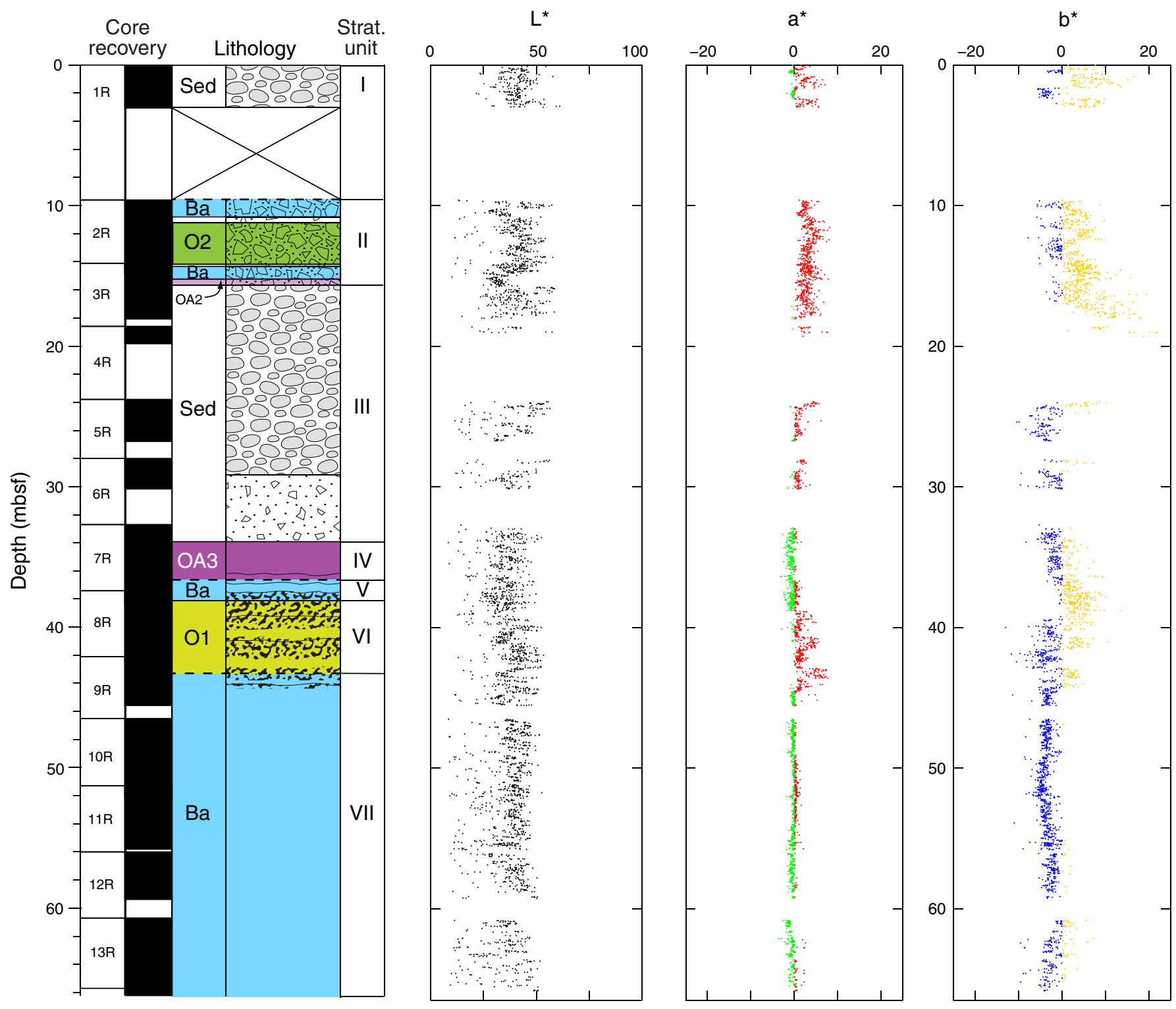
Figure F50. Plot of moisture and density Method C (MAD-C) bulk density values vs. porosity of discrete samples, Hole U1373A. Results show an approximately linear negative correlation.

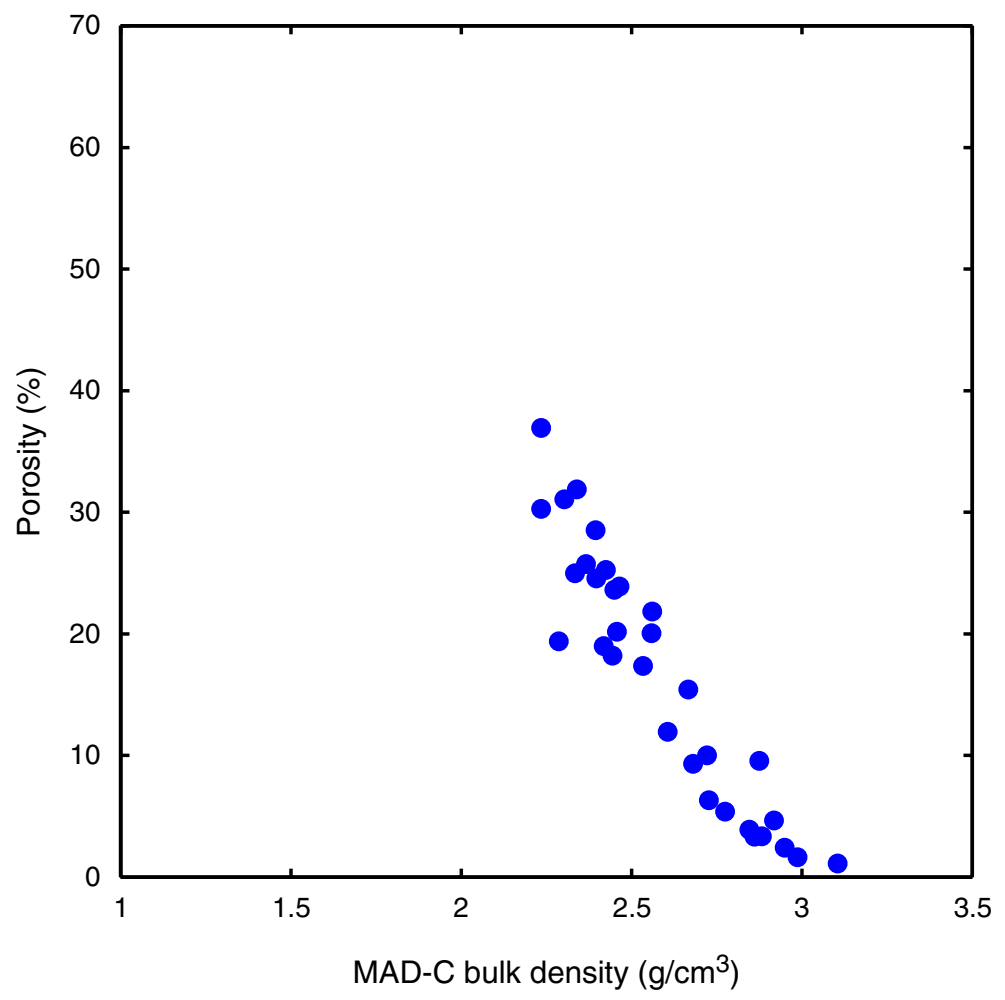


Figure F51. Plot of whole-round gamma ray attenuation (GRA) bulk density vs. moisture and density Method C (MAD-C) bulk density from discrete samples, Hole U1373A. Results show a nearly one-to-one linear relationship, with values from GRA bulk density often slightly lower than those from discrete samples.

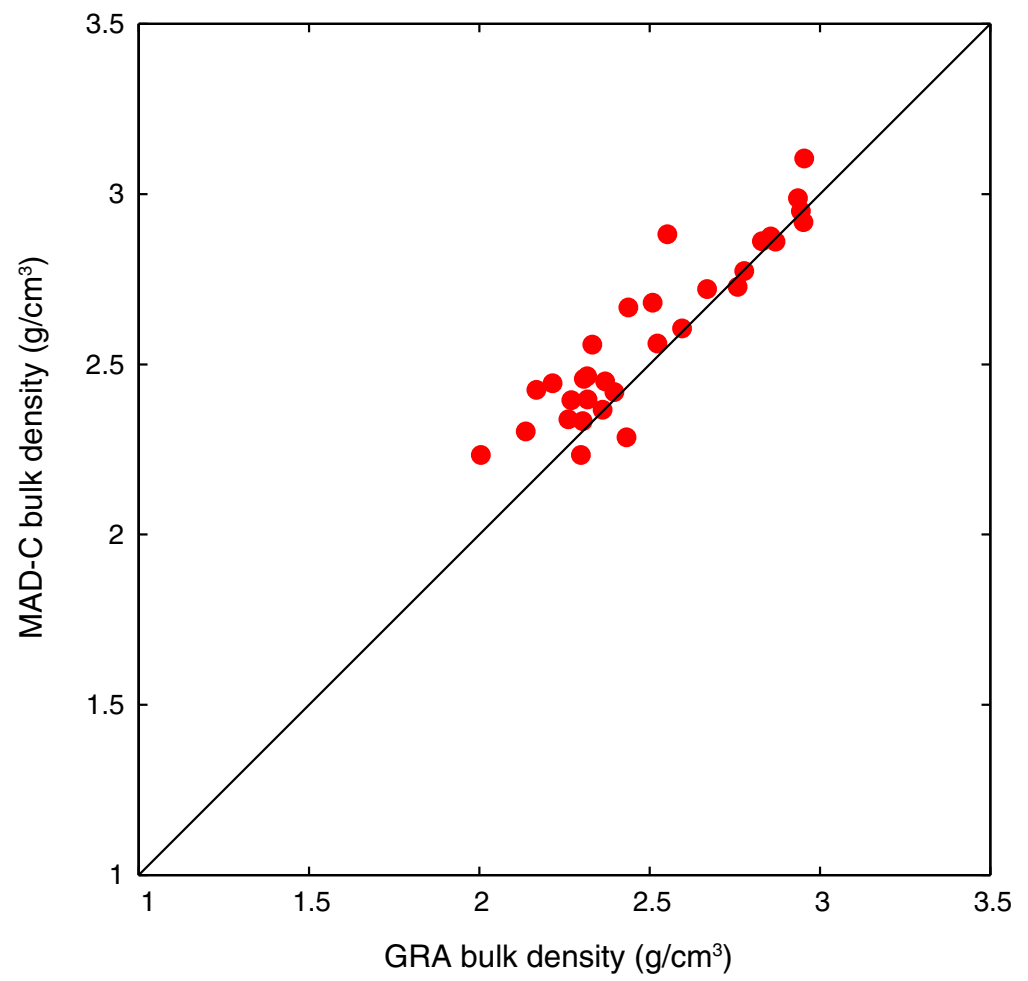


Figure F52. Depth profiles of porosity and thermal conductivity from discrete samples, Hole U1373A. Stratigraphic column is shown for reference. For explanation of stratigraphy, see Figure F11.

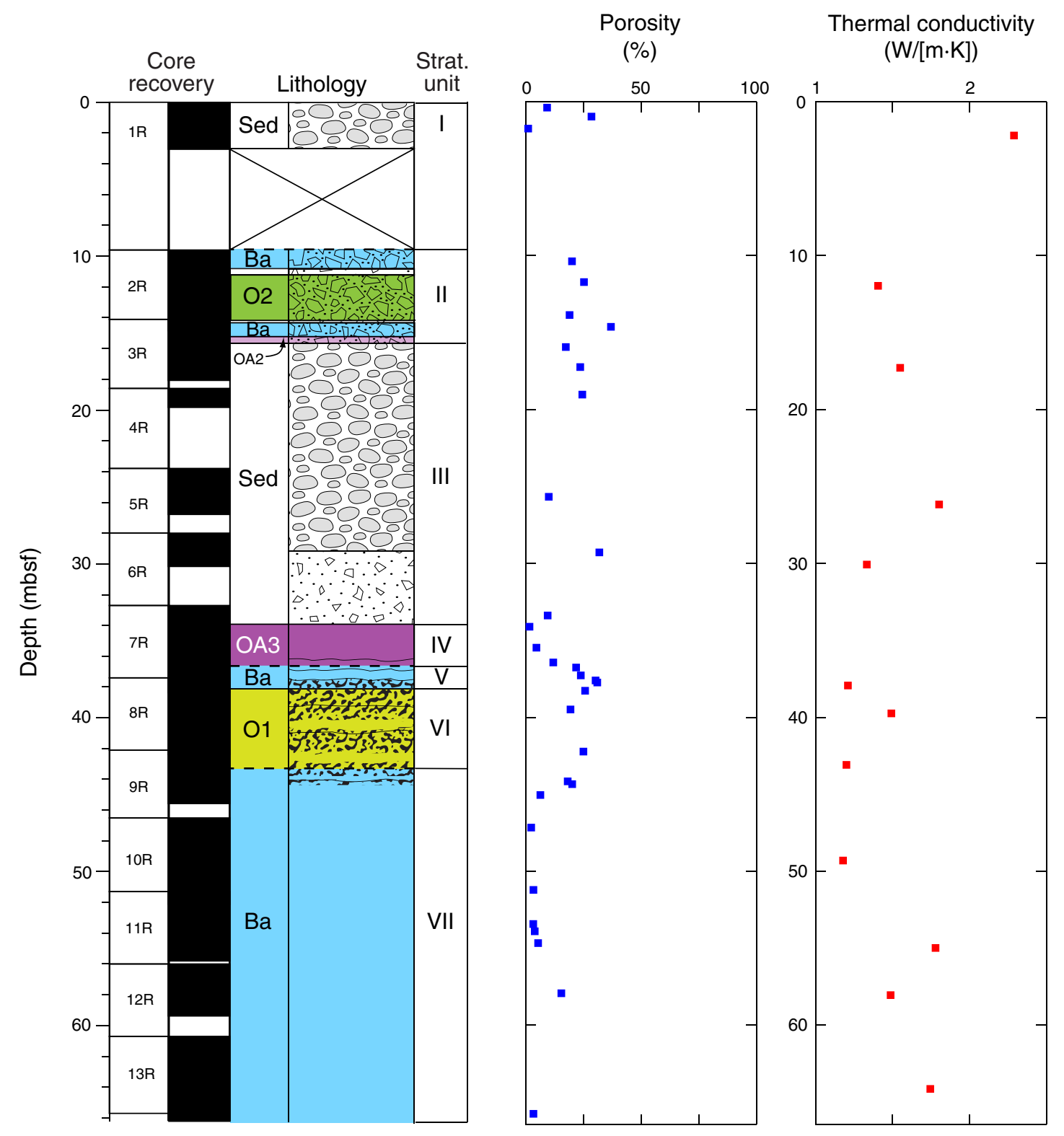


Figure F53. Plot of moisture and density Method C (MAD-C) bulk density from discrete samples vs. discrete $P$-wave velocity, Hole U1373A, showing an approximately linear relationship. Colors represent different orientations for $P$-wave velocity measurements: blue $=x$-axis (normal to the split-core surface), red $=y$-axis (parallel to the split-core surface), green $=z$-axis (downcore) .

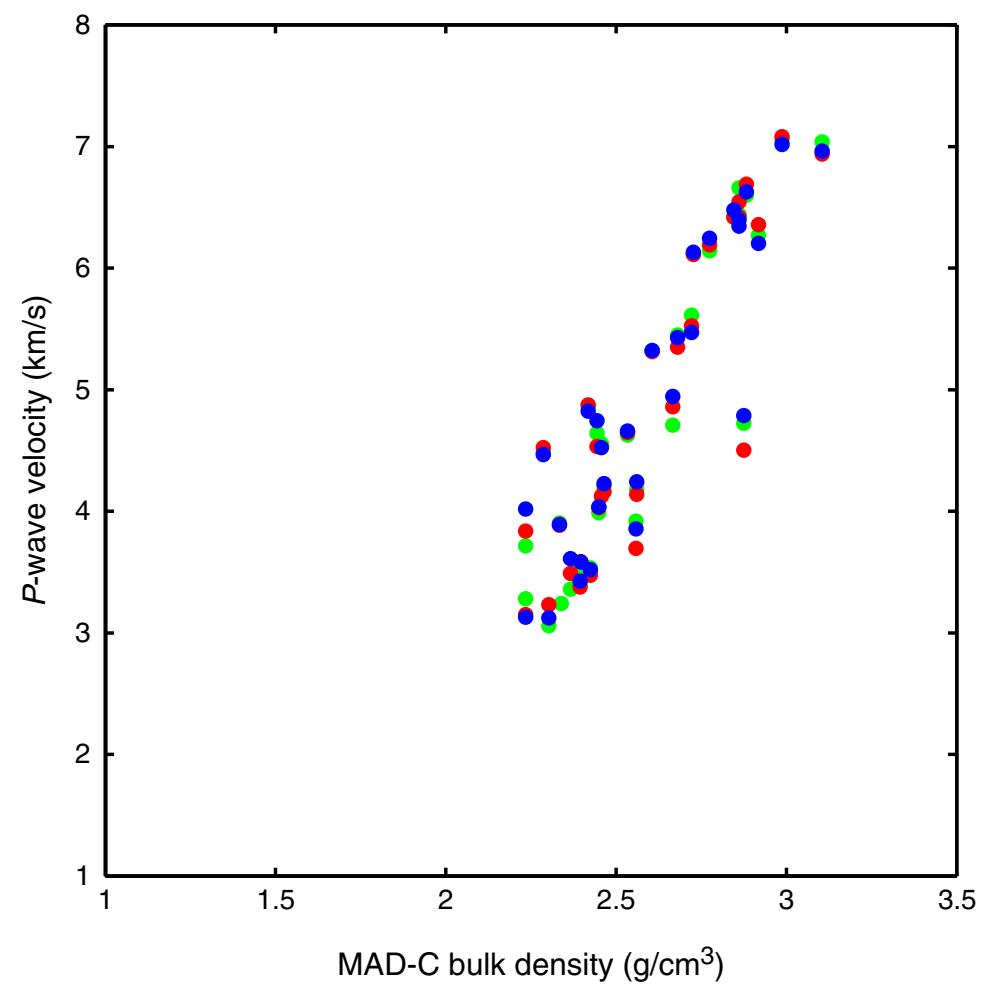


Figure F54. Plot of gamma ray attenuation (GRA) bulk density vs. thermal conductivity, Hole U1373A. The results show an approximately linear relationship. Outlier data point 330-U1373A-10R-3, $14 \mathrm{~cm}$, is shown in light pink.

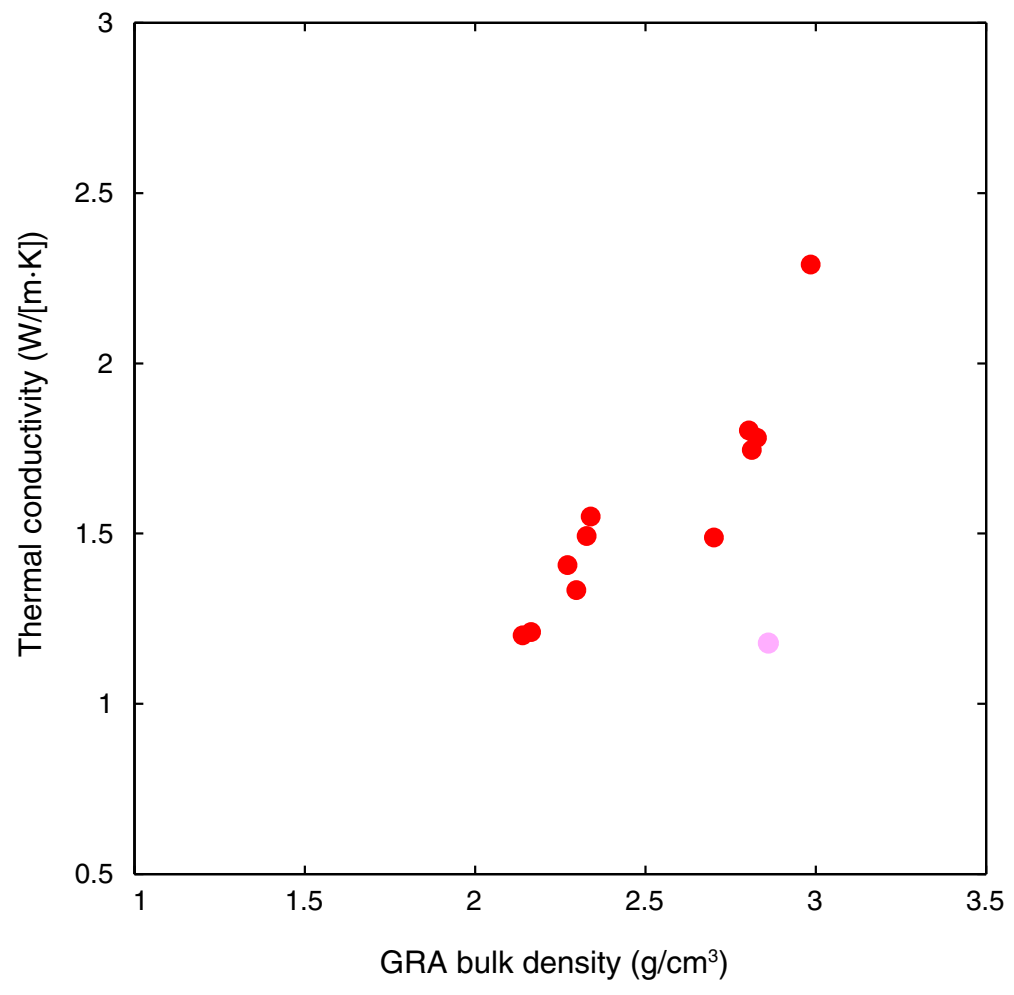


Figure F55. Downhole plots of paleomagnetic data from archive-half cores, Hole U1373A. A. Core recovery and observed stratigraphy (see Fig. F11 for explanation of patterns and abbreviations). B. Remanent intensity variations: purple $=$ NRM intensities, black $=$ intensities associated with PCA directions with misfits $\leq 3.42$, gray $=$ intensities associated with PCA directions with misfits > 3.42. C. WRMSL magnetic susceptibility (see "Physical properties"). D. Inclination: red $=$ PCA directions with misfits $\leq 3.42$, pink $=$ PCA directions with misfits $>3.42$. E. Median destructive field (MDF') of the vector difference sum (VDS) for PCA directions. (Figure shown on next page.) 
Figure F55 (continued). (Caption shown on previous page.)
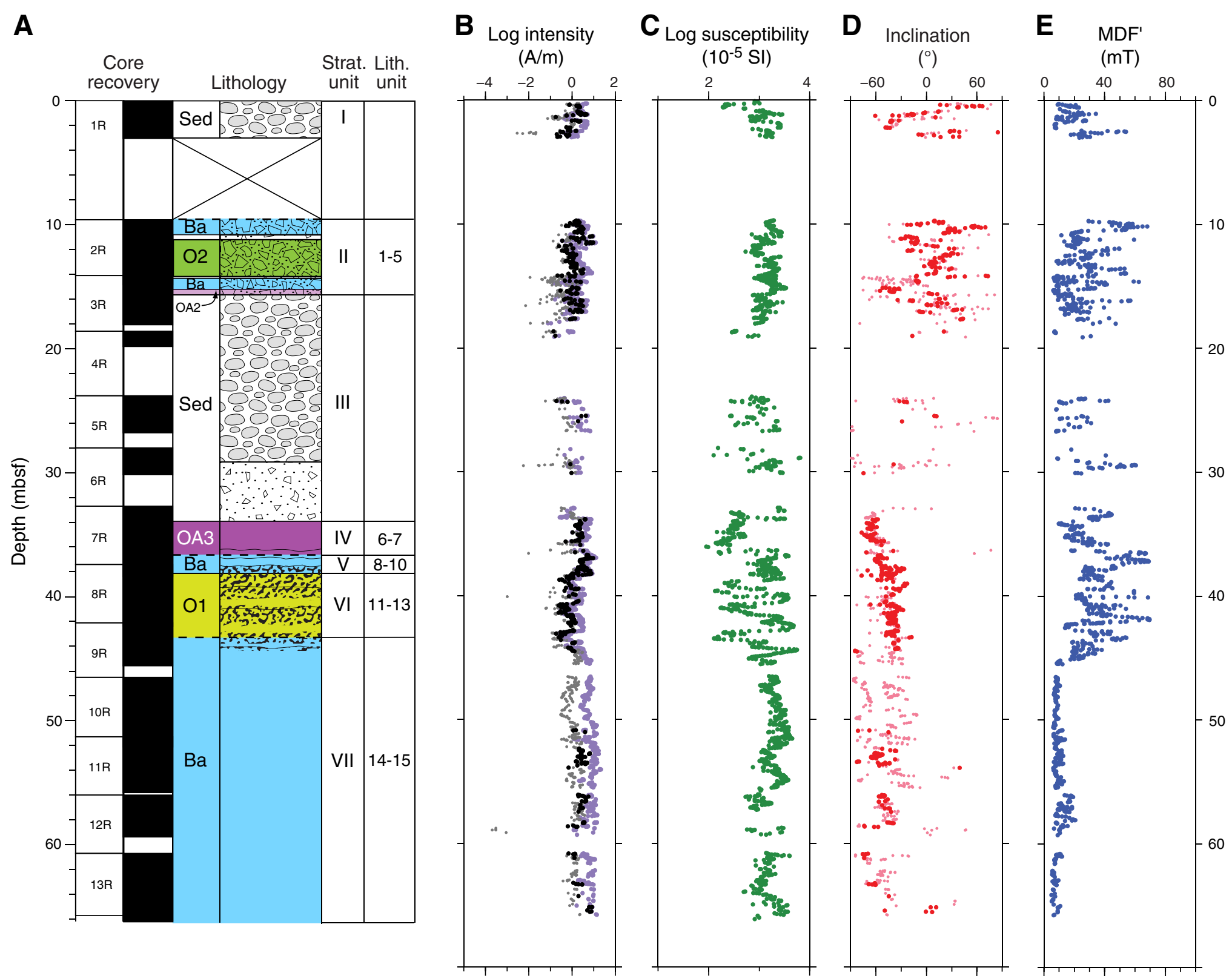
Figure F56. (A) Downhole inclination variation and (B) representative Zijderveld plots, Section 330-U1373A7R-4 (lithologic Units 8-10). In Zijderveld plots, solid circles = projections of vector endpoints onto horizontal plane, open circles $=$ projections onto vertical plane. Red arrows $=$ best fitting PCA direction calculated automatically and selected on basis of lowest misfit (solid red symbols in A). In A, pink circles = PCA directions with misfit $>3.42$, open circles with error bars $=$ Fisher piece averages. Discrete AF (triangles) and thermal (squares) demagnetization directions are also shown. NRM = natural remanent magnetization.

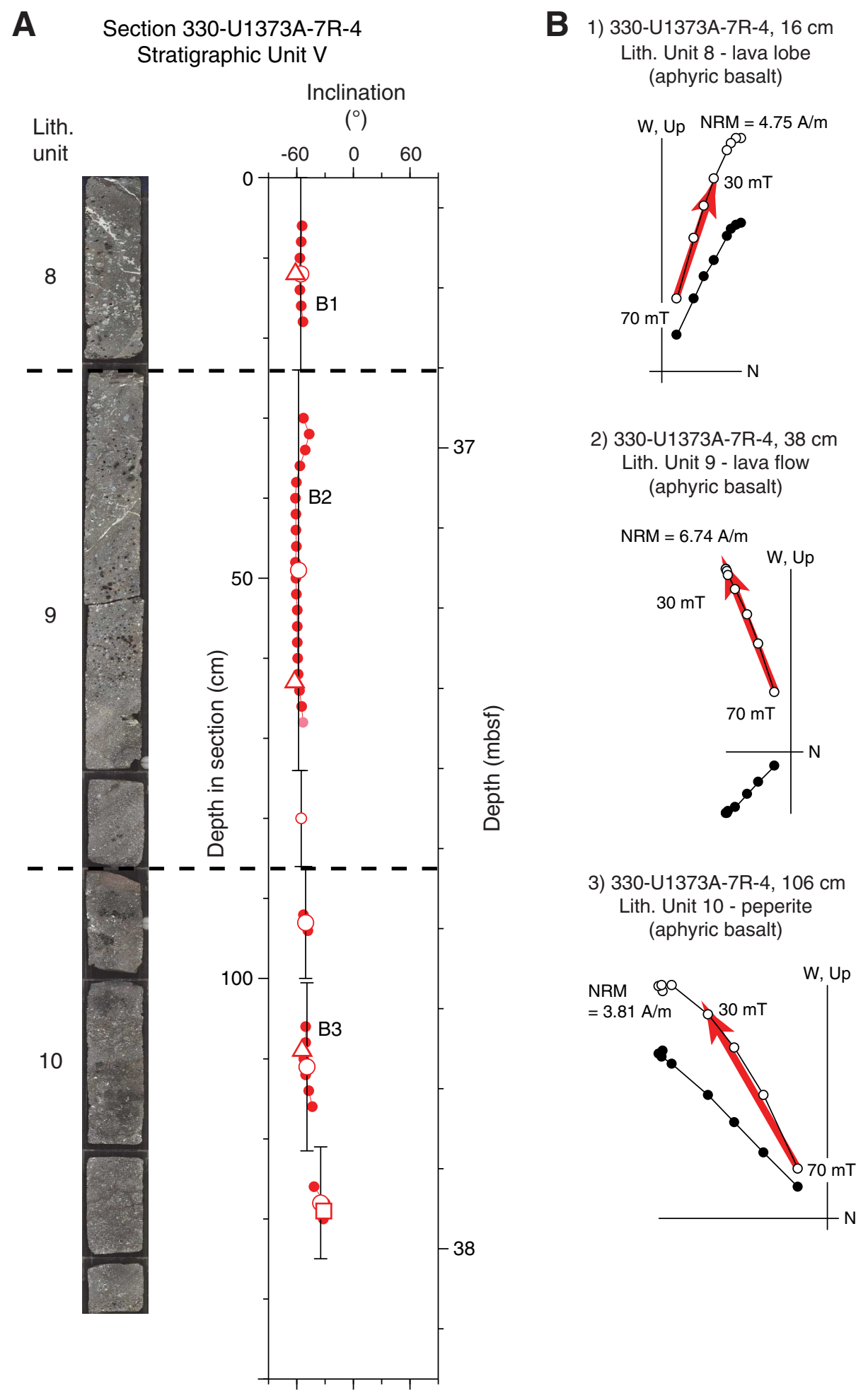


Figure F57. Log-log graph of bulk magnetic susceptibility vs. Königsberger ratio (Qn) for basalts (lavas and conglomerates), Hole U1373A.

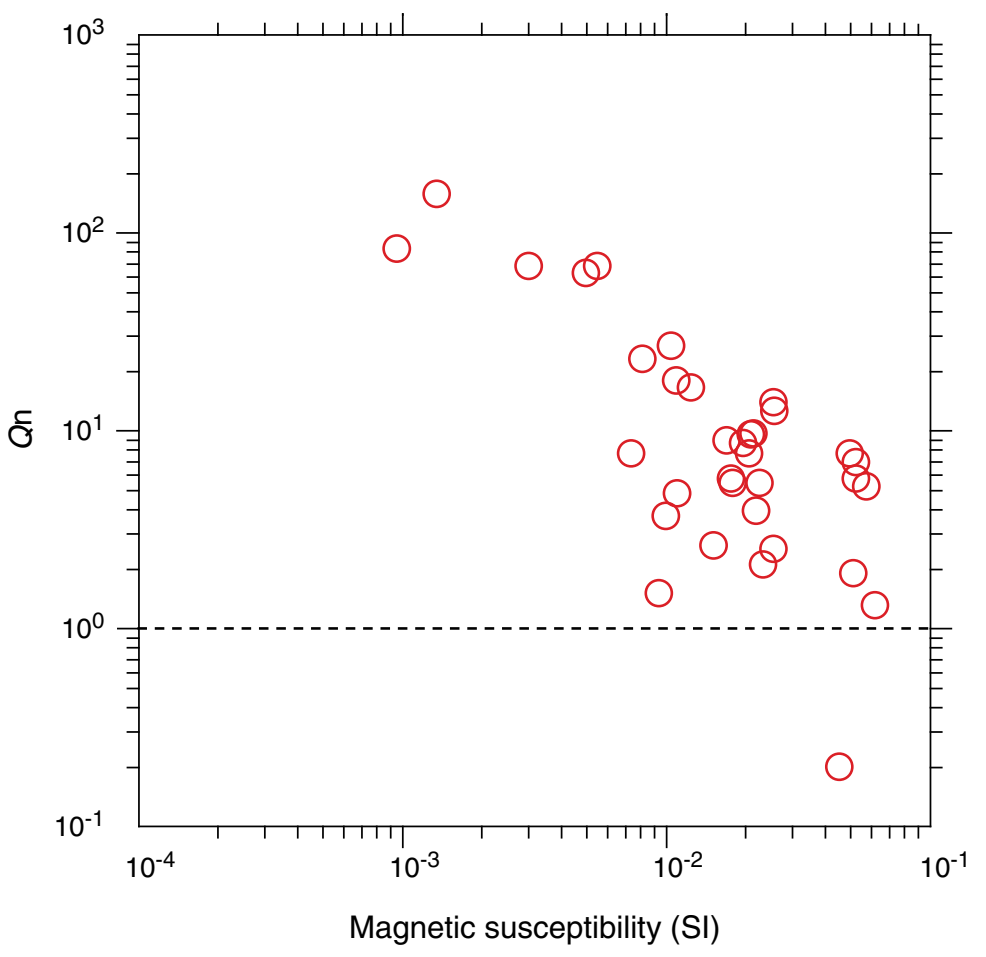




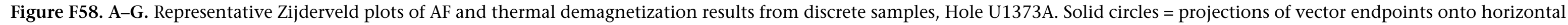

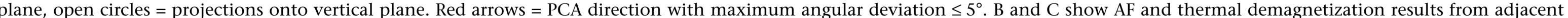
samples. G shows AF and thermal demagnetization results from samples in same stratigraphic unit. NRM = natural remanent magnetization.

A 330-U1373A-1R-2, 94-96 cm
Large basaltic clast Large basaltic clast

Unit l: Sedimentary conglomerate

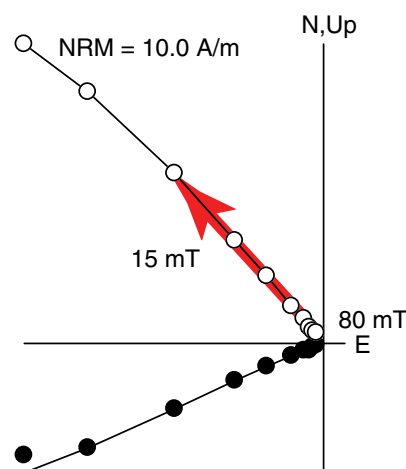

$\theta$

D

330-U1373A-7R-3, 5-7 cm

Unit IV: Massive lava flow

N,Up

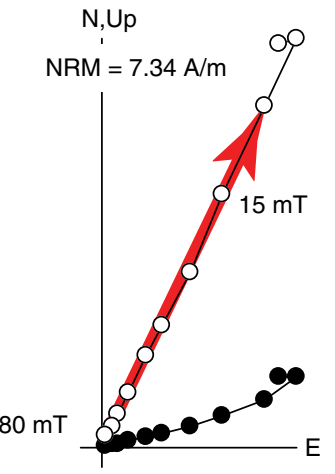

B

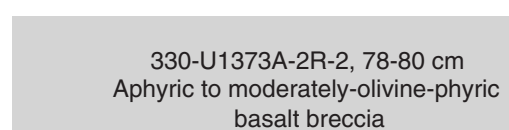

basalt brecivine-phyric

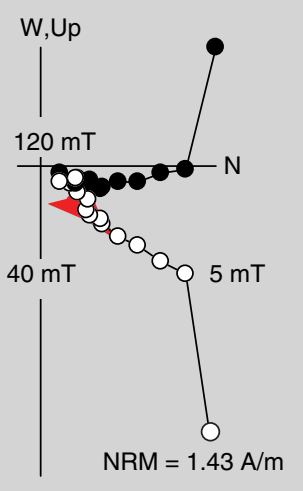

E

330-U1373A-7R-4, 128-130 cm

Unit V: Aphyric basalt peperite

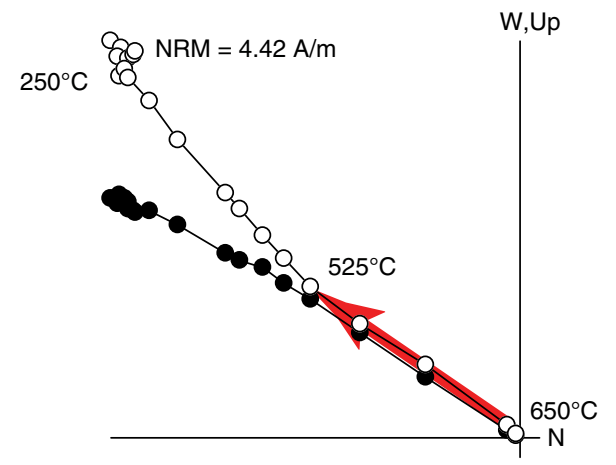

$330-U 1373 A-2 R-2,81-83 \mathrm{~cm}$
Aphyric to

Aphyric to moderately-olivine-phyric

basalt breccia

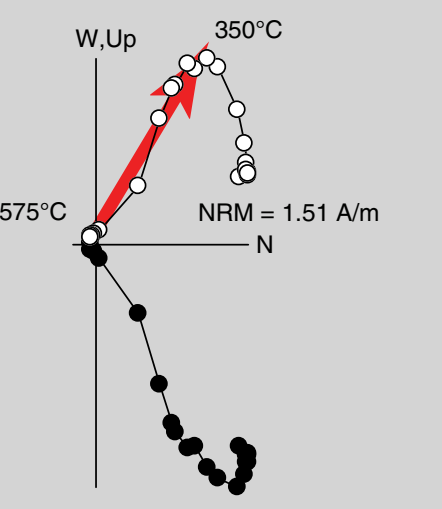

$\mathbf{F}$

330-U1373A-8R-2, 67-69 cm

Unit VI: Peperitic lava flow

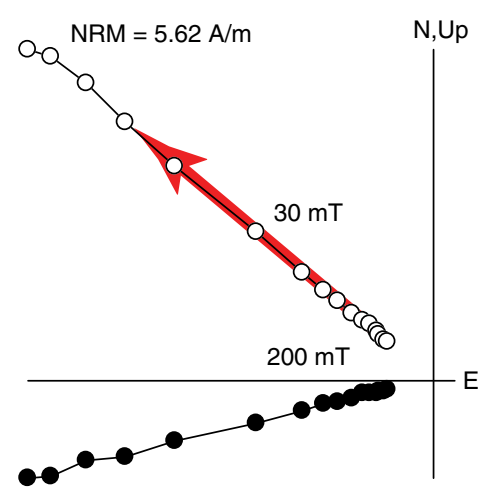

C

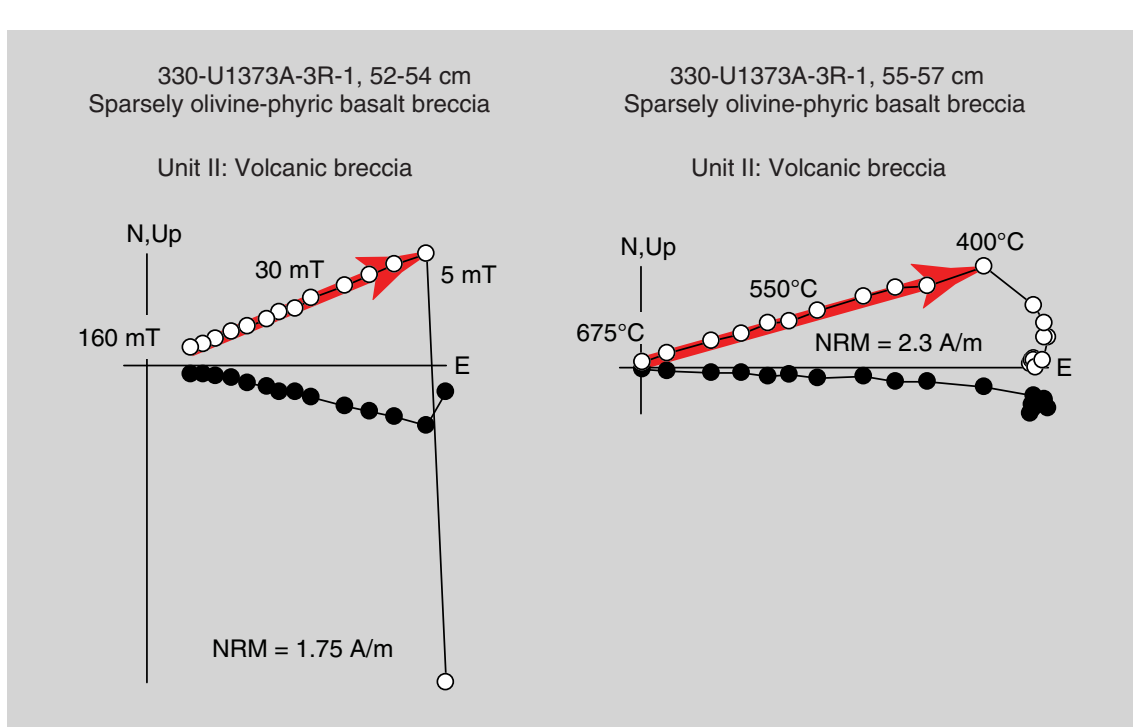

G

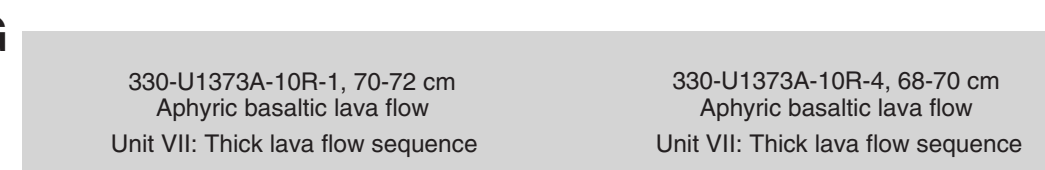
Unit VII: Thick lava flow sequence
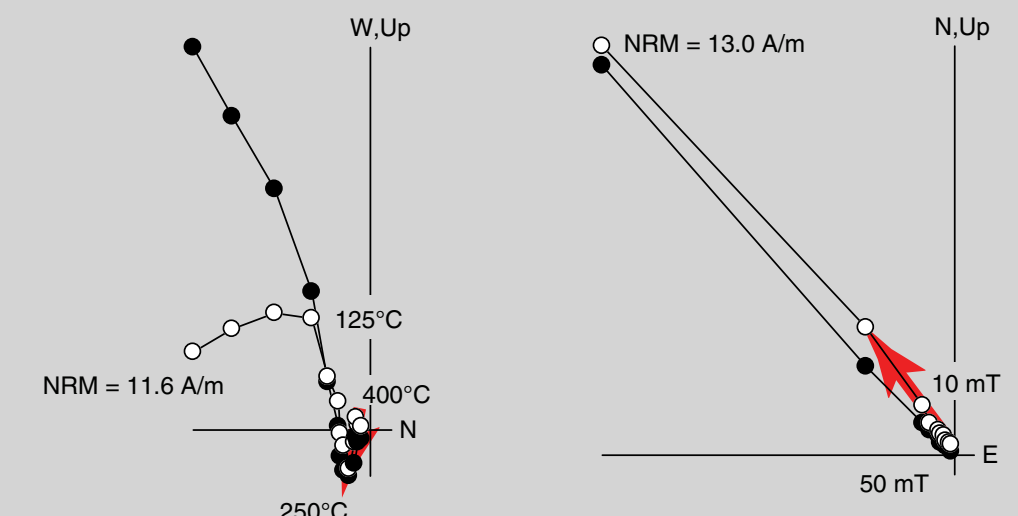
Figure F59. Downhole plots of inclination, Hole U1373A. A. Core recovery and observed stratigraphy (see Fig. F11 for explanation of patterns and abbreviations). B. All downhole inclination data measured at $2 \mathrm{~cm}$ intervals on archive-half cores: red $=$ PCA directions with misfits $\leq 3.42$, pink $=$ PCA directions with misfits $>3.42$. C. Average inclination for each lithologic unit (see "Igneous petrology and volcanology"), calculated using inclination-only statistics. D. Average inclination for each core piece longer than $9 \mathrm{~cm}$, calculated using Fisher statistics. E. Average inclination for each lithologic unit, calculated using average piece directions displayed in $\mathrm{D}$ and inclination-only statistics. F. Characteristic remanent magnetization inclinations from discrete samples (from alternating-field $[\mathrm{AF}]$ or thermal demagnetization) with maximum angular deviation $\leq 5^{\circ}$. Shading scheme for C-F represents the ISCI for identifying distinct lava flow units, where the darkest shade of blue is the most confident and green is not applicable (NA; i.e., deposits cannot have retained their orientation since cooling). (Figure shown on next page.) 
Figure F59 (continued). (Caption shown on previous page.)

A

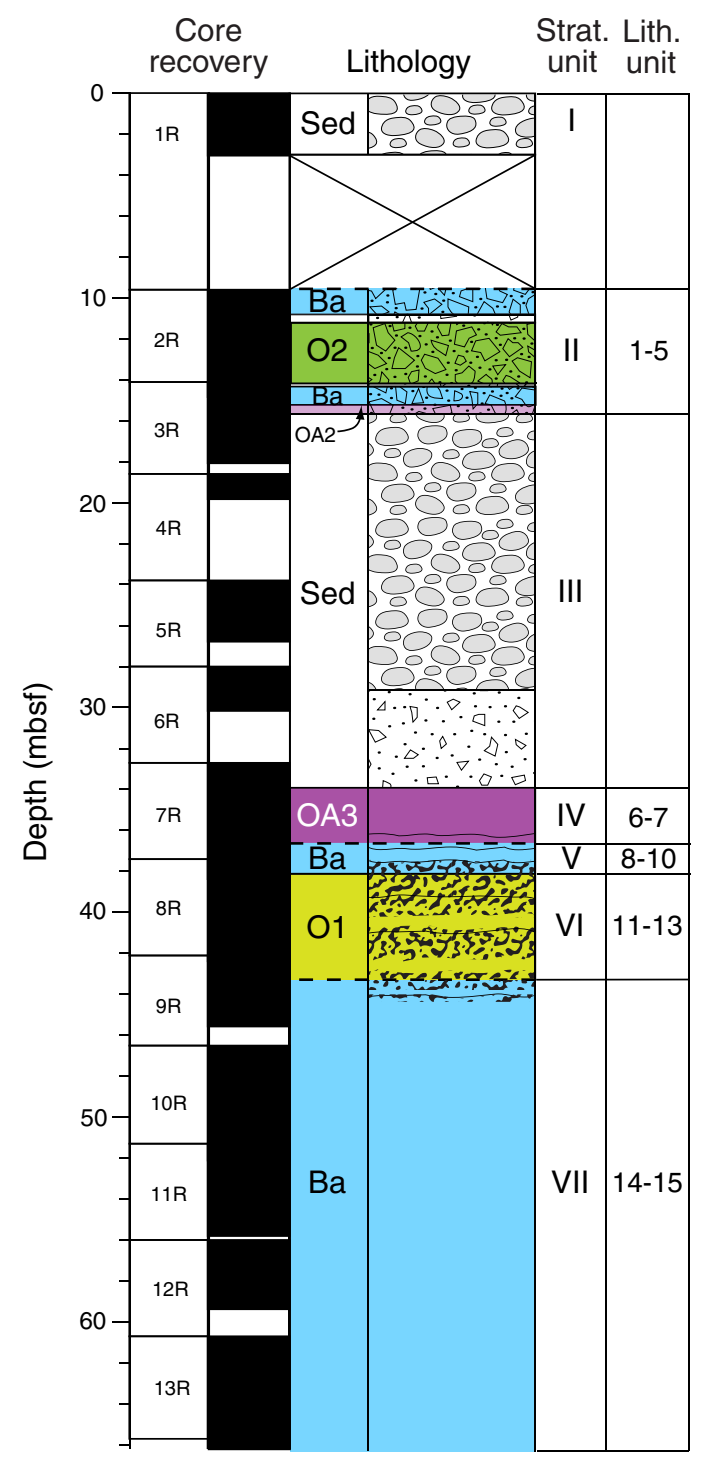

B Archive-half inclination $\left(^{\circ}\right)$
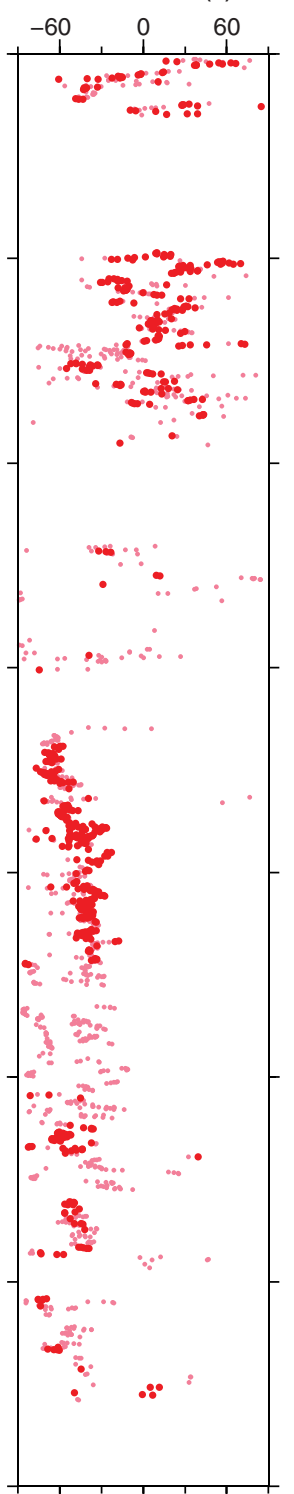

In situ confidence index (ISCI):
C Lith. unit inclination $\left(^{\circ}\right)$ $\begin{array}{r}-60 \\ 1\end{array}, \frac{0}{1}, \frac{60}{1}$

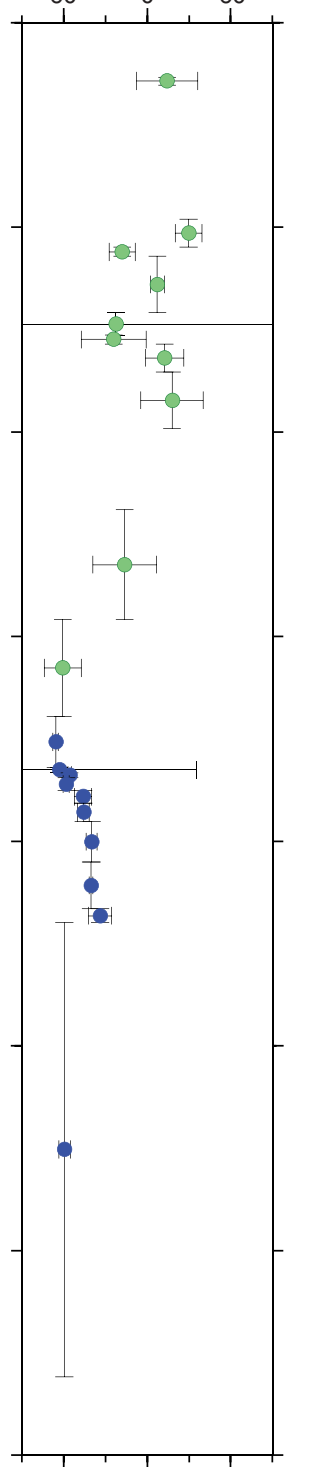

Lava flow (3)
D

inclination $\left({ }^{\circ}\right)$

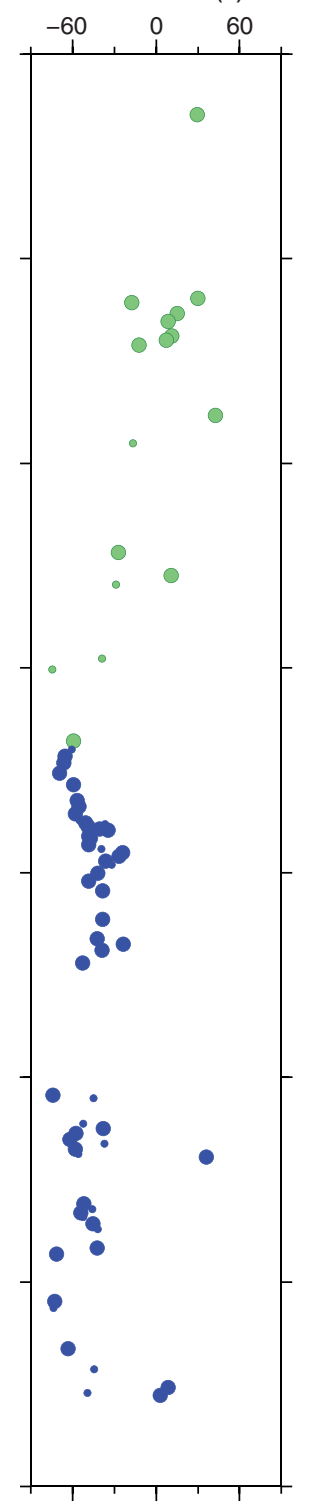

$\mathbf{E}_{\text {Lith. }}$

Lith. unit/Piece

inclination $\left(^{\circ}\right)$

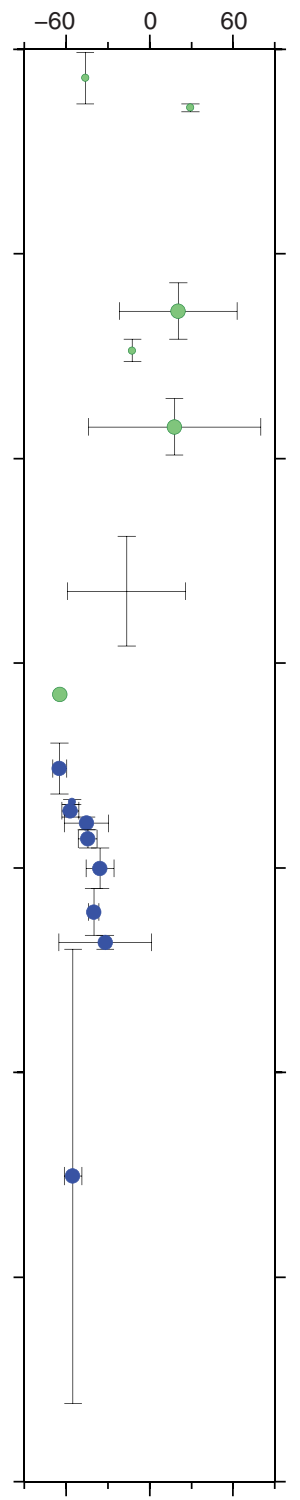

$\triangle-10$

$\triangle$

$-20$

4

$-30$

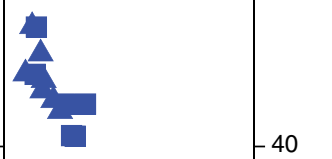

$-40$

-

$\Delta$

슨

$\Delta$

$-60$

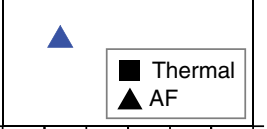


Figure F60. A. Core recovery and observed stratigraphy, Hole U1373A (see Fig. F11 for explanation of patterns and abbreviations). B. Plot of characteristic remanent magnetization inclination from alternating-field (AF) or thermally demagnetized discrete samples with maximum angular deviation $\leq 5^{\circ}$. Shading scheme represents the in situ confidence index (ISCI; see "Igneous petrology and volcanology" in the "Methods" chapter [Expedition 330 Scientists, 2012a]) for identifying distinct lava flow units, where the darkest shade of blue is the most confident and green is not applicable (NA; i.e., deposits cannot have retained their orientation since cooling). C-E. Histograms of inclination for (C) all archive-half $2 \mathrm{~cm}$ interval data with misfits $\leq 3.42$, (D) piece averages for pieces occurring in distinct lava flow units with an ISCI of 3, and (E) discrete samples taken from lava flow units with an ISCI of 3 . Statistics presented in the inset panels are inclination-only means $\left( \pm \alpha_{95}\right)$. Note that because of the uncertainty in whether some individual units are in situ, averages by lithologic unit have not been calculated. Faint colored histograms in background are equivalent results from Hole U1372A for comparison (not included in statistical calculations).

A

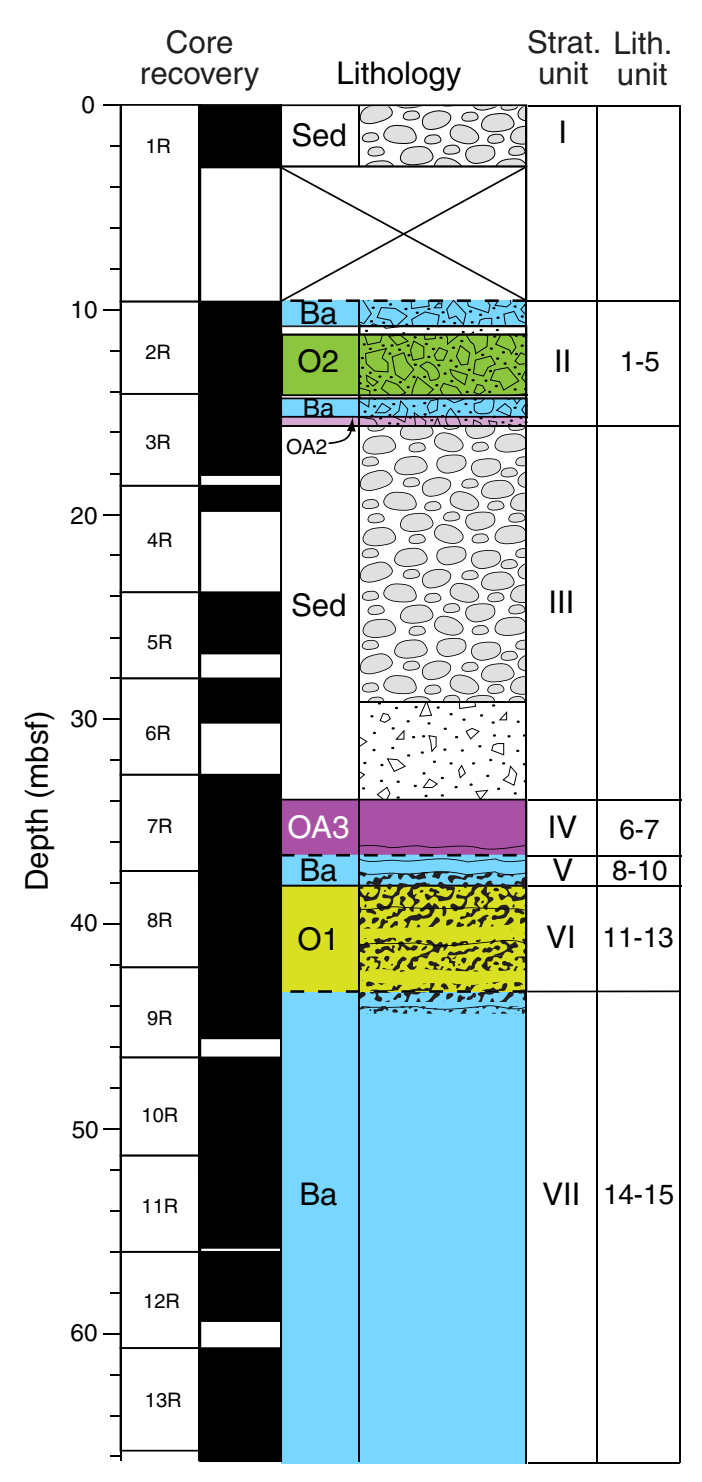

B

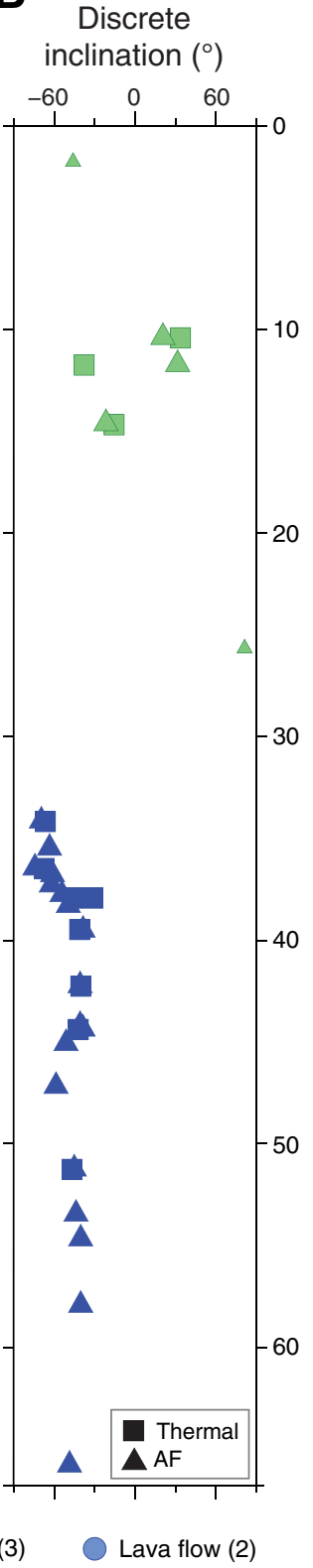

In situ confidence index (ISCI):

Lava flow (3)

NA

C

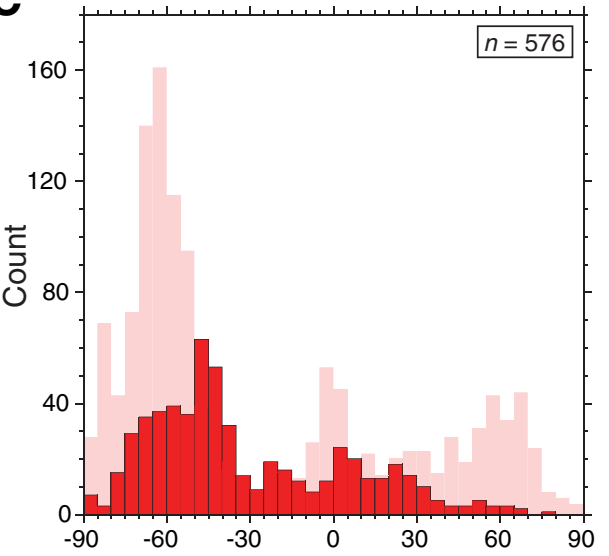

D

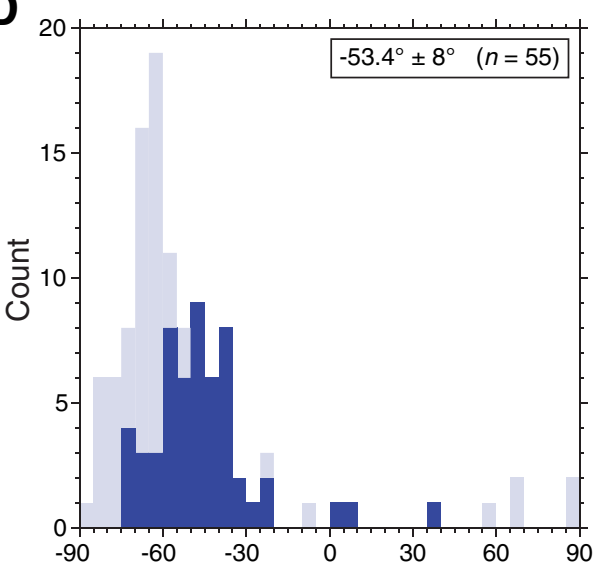

E

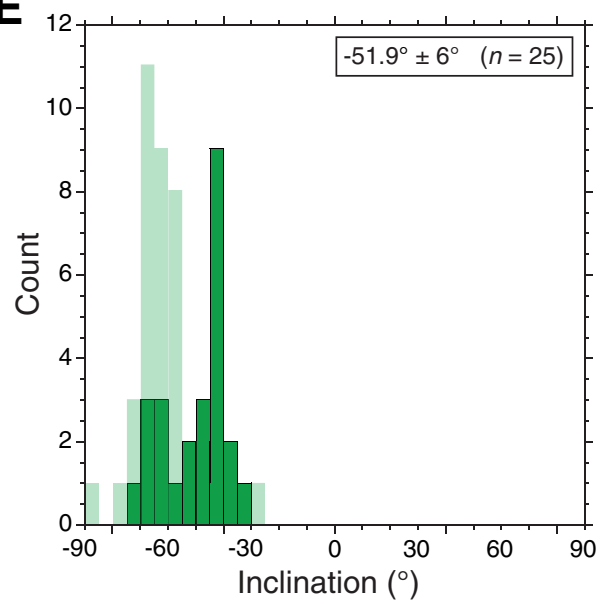


Figure F61. Schematic showing locations of microbiology (MBIO) samples, Hole U1373A.

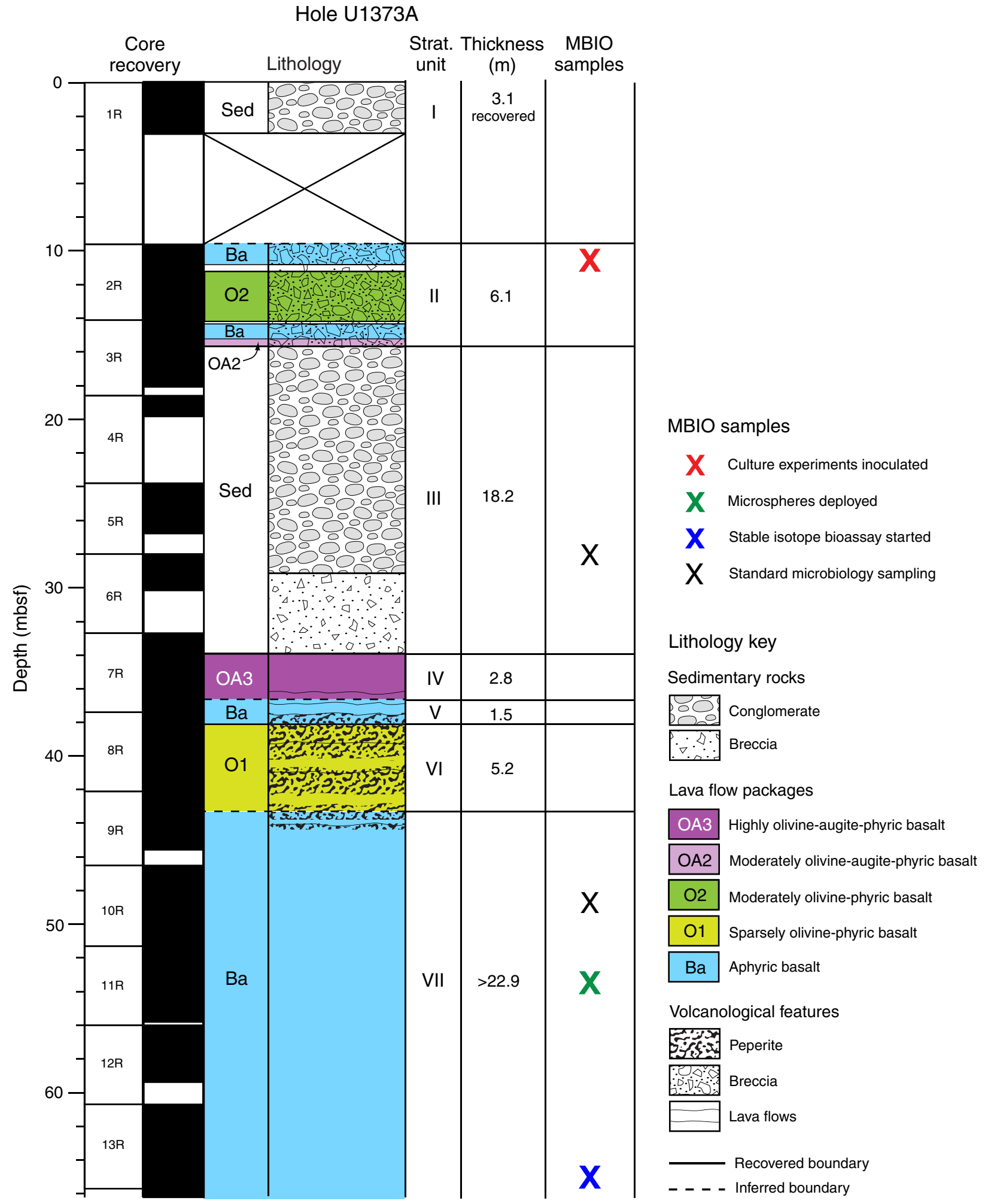


Figure F62. Photographs of whole-round samples collected for microbiology analysis, along with sample depth and lithology.

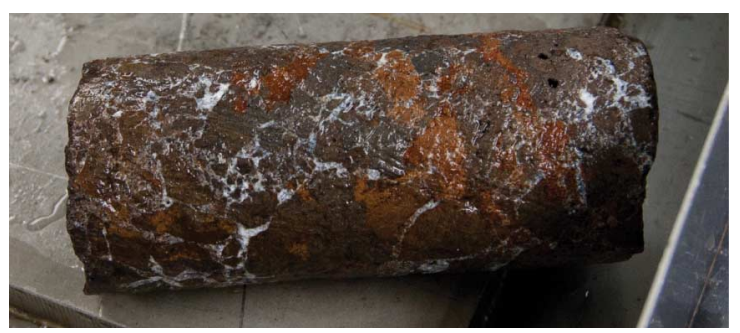

330-U1373A-2R-1, 120-133 cm;

$10.8 \mathrm{mbsf}$

Aphyric basalt breccia

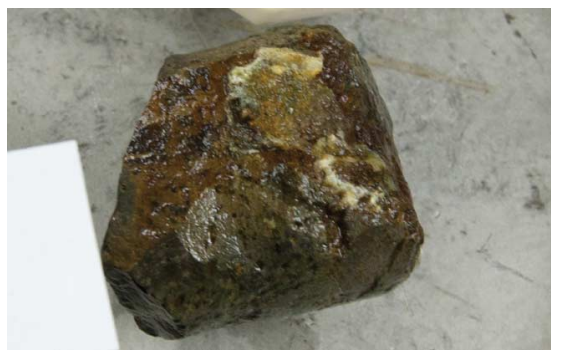

330-U1373A-6R-1, 72-78 cm;

$28.72 \mathrm{mbsf}$

Sedimentary conglomerate

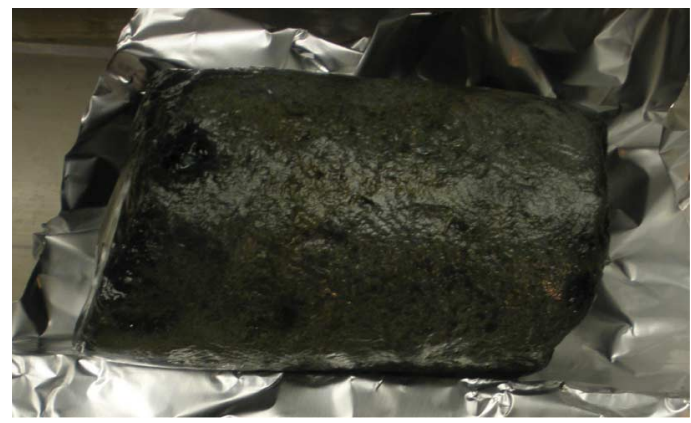

330-U1373A-10R-2, 114-123 cm; $48.87 \mathrm{mbsf}$

Aphyric basalt

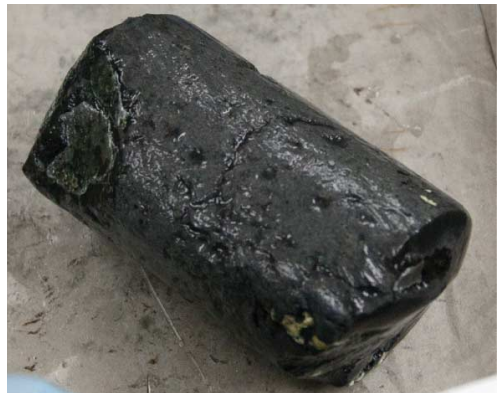

330-U1373A-11R-2, $122-133 \mathrm{~cm}$; $53.84 \mathrm{mbsf}$

Aphyric basalt

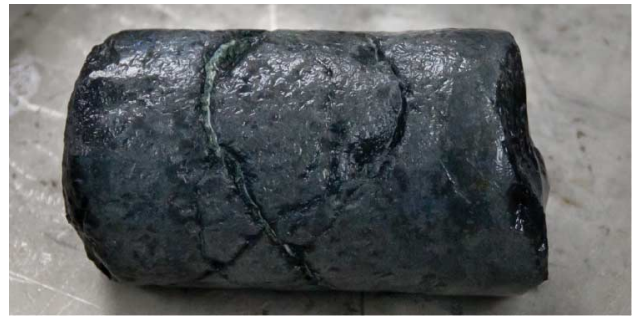

330-U1373A-13R-3, 118-128 cm; $64.76 \mathrm{mbsf}$

Aphyric basalt 
Figure F63. Top: Photograph of five rock sections cut and counted for microsphere intrusion in Sample 330U1373A-11R-2, 122-133 cm. Subsamples for microsphere counts were taken from area between dashed yellow lines. Bottom: Photograph of delivered microsphere bag in core liner of Core 330-U1373A-11R.
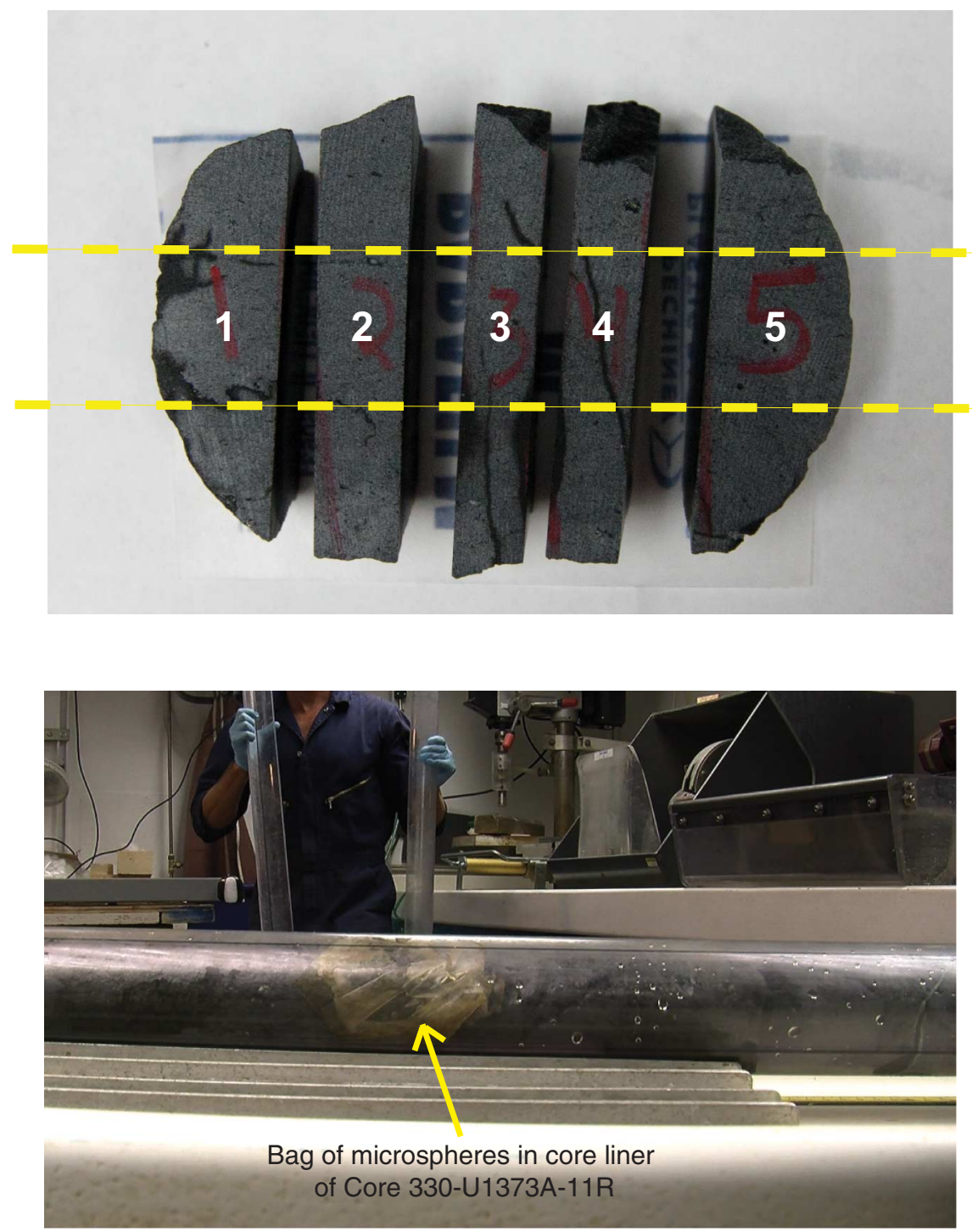
Table T1. Coring summary, Site U1373.

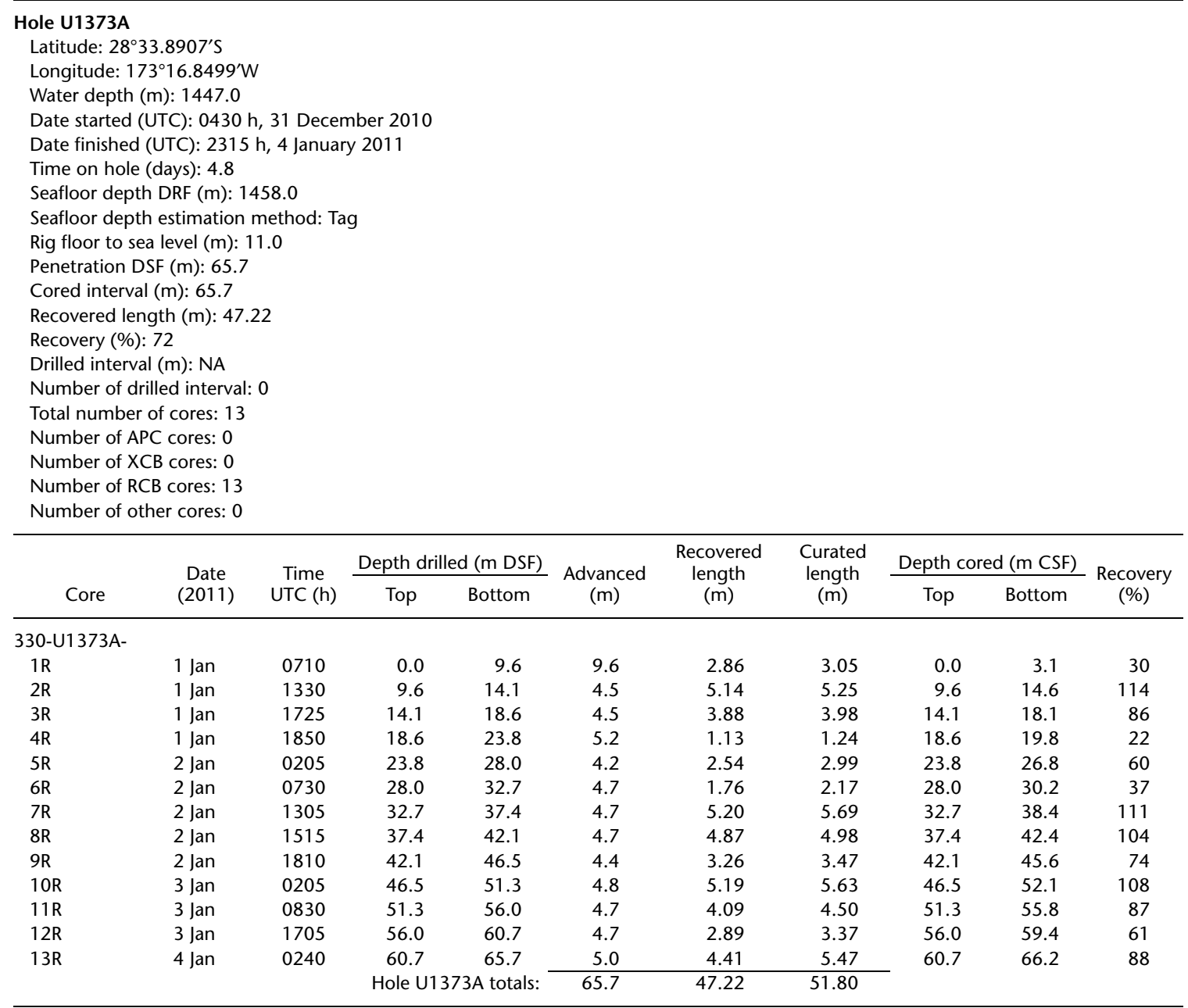

$\mathrm{NA}=$ not applicable. UTC $=$ universal time coordinated. DRF $=$ drilling depth below rig floor, DSF $=$ drilling depth below seafloor, $C S F=$ core depth below seafloor. $A P C=$ advanced piston corer (core type $\mathrm{H}$ ), $\mathrm{XCB}=$ extended core barrel (core type $\mathrm{X}$ ), $\mathrm{RCB}=$ rotary core barrel $($ core type R). 
Table T2. Occurrence of basalt clast types, Site U1373.

\begin{tabular}{|c|c|c|c|c|c|c|c|c|c|c|c|c|}
\hline \multirow[b]{3}{*}{$\begin{array}{l}\text { Strat. } \\
\text { unit }\end{array}$} & \multicolumn{12}{|c|}{ Basalt clasts } \\
\hline & Type 1 & Type 2 & Type 3 & Type 4 & Type 5 & Type 6 & Type 7 & Type 8 & Type 9 & Type 10 & Type 11 & Type 12 \\
\hline & $\begin{array}{l}\text { Moderately } \\
\text { plagioclase- } \\
\text { olivine-phyric } \\
\text { basalt, } 3 \% \\
\text { vesicles, light } \\
\text { reddish gray }\end{array}$ & $\begin{array}{l}\text { Aphyric basalt, } \\
0 \%-10 \% \text { vesicles, } \\
\text { brownish gray }\end{array}$ & $\begin{array}{c}\text { Aphyric basalt, } \\
15 \% \text { vesicles, } \\
\text { light gray }\end{array}$ & $\begin{array}{l}\text { Highly olivine- } \\
\text { phyric basalt, } \\
3 \% \text { vesicles, } \\
\text { reddish gray }\end{array}$ & $\begin{array}{l}\text { Aphyric basalt, } \\
15 \% \text { vesicles, } \\
\text { reddish } \\
\text { medium gray to } \\
\text { brownish gray }\end{array}$ & $\begin{array}{c}\text { Moderately } \\
\text { plagioclase- } \\
\text { phyric basalt, } \\
10 \% \text { vesicles, } \\
\text { reddish } \\
\text { medium gray }\end{array}$ & $\begin{array}{l}\text { Highly olivine- } \\
\text { augite-phyric } \\
\text { basalt, 7\% } \\
\text { vesicles, } \\
\text { medium gray }\end{array}$ & $\begin{array}{c}\text { Aphyric basalt, } \\
10 \% \text { vesicles, } \\
\text { brown-orange } \\
\text { gray }\end{array}$ & $\begin{array}{c}\text { Highly } \\
\text { plagioclase- } \\
\text { phyric basalt, } \\
1 \% \text { vesicles, } \\
\text { medium gray }\end{array}$ & $\begin{array}{c}\text { Aphyric basalt, } \\
15 \% \text { vesicles, } \\
\text { pale orange- } \\
\text { gray }\end{array}$ & $\begin{array}{c}\text { Aphyric basalt, } \\
10 \% \text { vesicles, } \\
\text { medium gray }\end{array}$ & $\begin{array}{l}\text { Aphyric basalt, } \\
0.5 \% \text { vesicles, } \\
\text { brownish red }\end{array}$ \\
\hline IA & $x$ & $x$ & & & & & & & & & & \\
\hline IB & $x$ & $x$ & $x$ & $x$ & $\mathrm{x}$ & $x$ & $x$ & & & & & \\
\hline IC & & & & & $x$ & & & & & & & \\
\hline ॥ & ND & ND & ND & ND & ND & ND & ND & ND & ND & ND & ND & ND \\
\hline IIIA & $x$ & $x$ & $x$ & $x$ & $x$ & $x$ & & $x$ & & & & \\
\hline IIIB & & $x$ & $x$ & & $x$ & $x$ & $x$ & $x$ & & & & \\
\hline IIIC & $x$ & $x$ & & $x$ & & $x$ & $x$ & $x$ & $x$ & & & \\
\hline IIID & & & & & & & $x$ & & & $x$ & $x$ & $x$ \\
\hline
\end{tabular}

$\mathrm{ND}=$ not determined. Details on nature and occurrence of clast types are available in SEDIMENT in "Supplementary material." 
Table T3. Nannofossils, Hole U1373A.

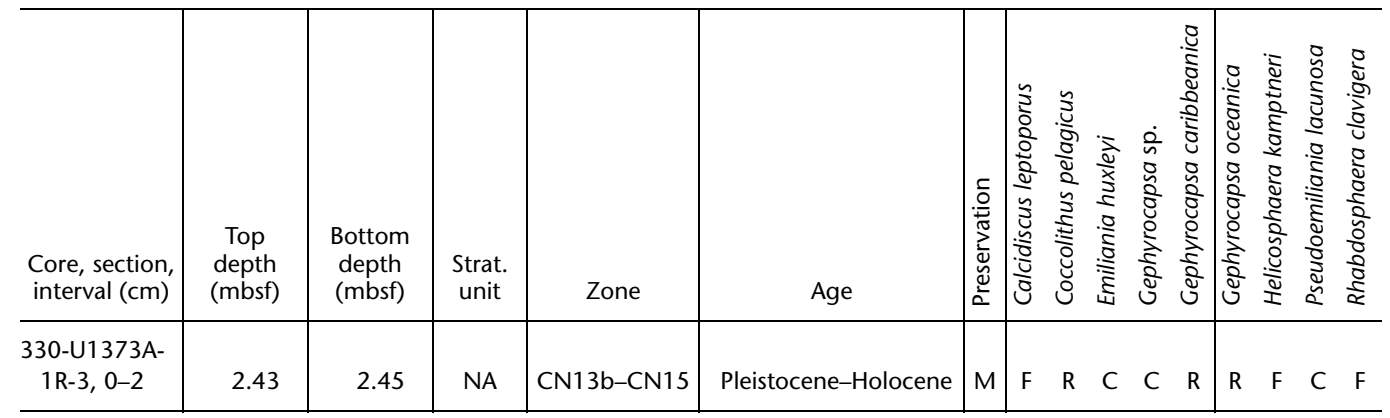

$\mathrm{NA}=$ not applicable. Preservation: $\mathrm{M}=$ moderate. Abundance: $\mathrm{C}=$ common, $\mathrm{F}=$ few, $\mathrm{R}=$ rare.

Table T4. Distribution of planktonic foraminifers, Hole U1373A.

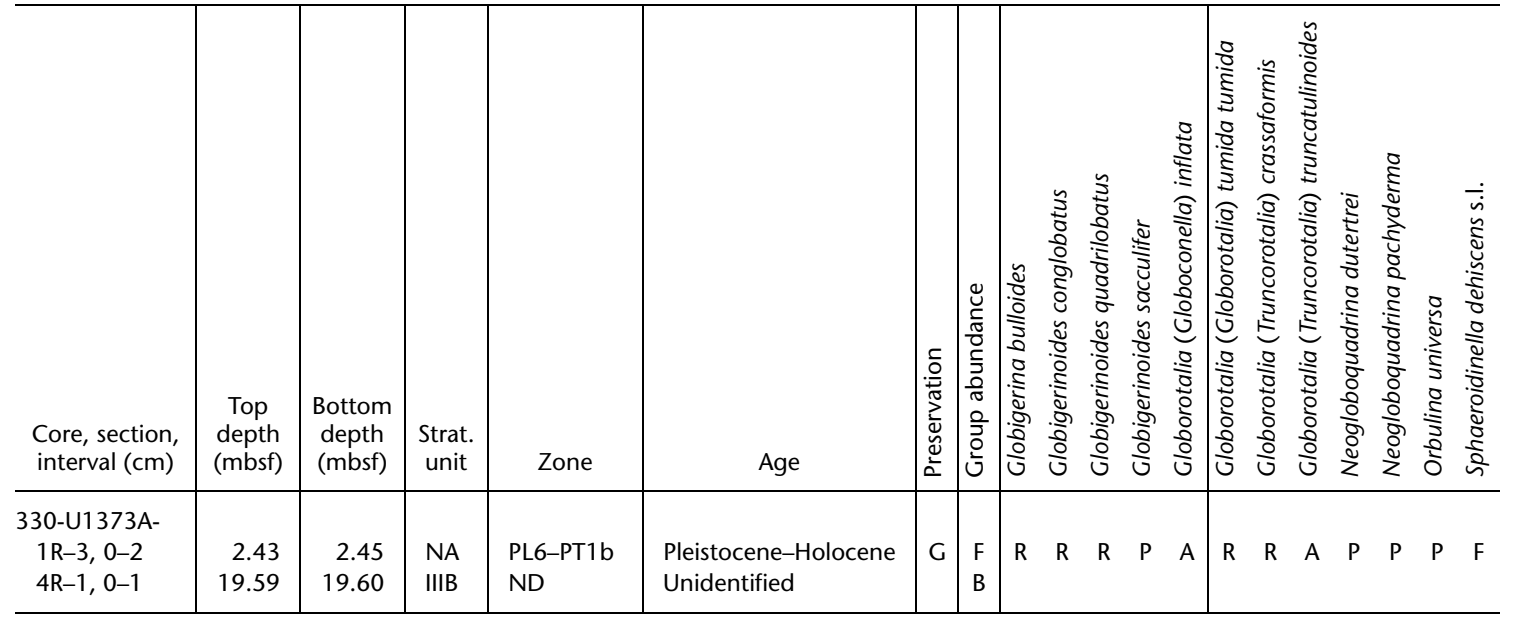

$\mathrm{NA}=$ not applicable, $\mathrm{ND}=$ not defined. Preservation: $\mathrm{G}=$ good. Abundance: $\mathrm{A}=$ abundant, $\mathrm{F}=$ few, $\mathrm{R}=$ rare, $\mathrm{P}=$ present, $\mathrm{B}=$ barren.

Table T5. In situ confidence index (ISCI) for igneous lithologic units, Site U1373.

\begin{tabular}{|c|c|c|c|c|}
\hline $\begin{array}{l}\text { Lith. } \\
\text { unit }\end{array}$ & $\mathrm{ISCl}$ & $\begin{array}{l}\text { Core, section, } \\
\text { interval }(\mathrm{cm})\end{array}$ & Unit description & $\begin{array}{l}\text { Strat. } \\
\text { unit }\end{array}$ \\
\hline & & 330-U1373A- & & \\
\hline 1 & NA & $2 \mathrm{R}-1,0$, to $2 \mathrm{R}-2,5$ & Volcanic breccia & II \\
\hline 2 & NA & $2 \mathrm{R}-2,5$, to $2 \mathrm{R}-2,49$ & Polylithic breccia & II \\
\hline 3 & NA & $2 \mathrm{R}-2,49$, to $2 \mathrm{R}-4,45$ & Volcanic breccia & II \\
\hline 4 & NA & $2 \mathrm{R}-4,45$, to $3 \mathrm{R}-2,21$ & Volcanic breccia (top $17 \mathrm{~cm}$ polylithic) & ॥ \\
\hline 5 & NA & $3 R-2,21$, to $3 R-2,64$ & Volcanic breccia & II \\
\hline - & - & $3 \mathrm{R}-2,64$, to $7 \mathrm{R}-1,121$ & Sedimentary unit & III \\
\hline 6 & 3 & $7 \mathrm{R}-1,121$, to $7 \mathrm{R}-3,96$ & Massive lava flow & IV \\
\hline 7 & 3 & $7 \mathrm{R}-3,96$, to $7 \mathrm{R}-3,123$ & Lava lobe & IV \\
\hline 8 & 3 & $7 R-4,0$, to $7 R-4,24$ & Lava lobe & $\mathrm{v}$ \\
\hline 9 & 3 & $7 \mathrm{R}-4,24$, to $7 \mathrm{R}-4,87$ & Lava flow & $\mathrm{V}$ \\
\hline 10 & 3 & $7 \mathrm{R}-4,87$, to $7 \mathrm{R}-5,5.5$ & Peperite & $\mathrm{V}$ \\
\hline 11 & 3 & $7 \mathrm{R}-5,5.5$, to $8 \mathrm{R}-2,22.5$ & Peperite & $\mathrm{VI}$ \\
\hline 12 & 3 & $8 \mathrm{R}-2,22.5$, to $8 \mathrm{R}-3,75$ & Lava flow with peperite top and base & $\mathrm{VI}$ \\
\hline 13 & 3 & $8 \mathrm{R}-3,75$, to $9 \mathrm{R}-1,121$ & Peperitic lava flow & $\mathrm{VI}$ \\
\hline 14 & 3 & $9 \mathrm{R}-2,0$, to $9 \mathrm{R}-2,66.5$ & Peperitic lava flow & VII \\
\hline 15 & 3 & $9 \mathrm{R}-2,66.5$, to $13 \mathrm{R}-4,117$ & Lava flow with peperite top & VII \\
\hline
\end{tabular}

ISCI: 0 = unlikely to be in situ, 1 = could be in situ, 2 = probably in situ, $3=$ highly likely to be in situ, NA = not applicable. See "Igneous petrology and volcanology" in the "Methods" chapter (Expedition 330 Scientists, 2012a) for a full explanation of the ISCI. - = not determined. 
Table T6. Occurrence of fresh or nearly fresh olivine and volcanic glass in thin section, Hole U1373A.

\begin{tabular}{|c|c|c|c|c|c|}
\hline Core, section & $\begin{array}{l}\text { Thin } \\
\text { section }\end{array}$ & $\begin{array}{l}\text { Depth } \\
\text { (mbsf) }\end{array}$ & Rocks & $\begin{array}{l}\text { Olivine freshness } \\
\text { (\%) }\end{array}$ & $\begin{array}{c}\text { Glass freshness } \\
(\%)\end{array}$ \\
\hline \multicolumn{6}{|l|}{ 330-U1373A- } \\
\hline 1R-2 & 76 & 2.04 & Sediment with volcanic clasts & 90 & 20 \\
\hline $1 \mathrm{R}-3$ & 77 & 2.97 & Sediment with volcanic clasts & - & 30 \\
\hline 7R-2 & 90 & 35.23 & Massive lava flow & 80 & - \\
\hline $7 R-3$ & 91 & 36.38 & Massive lava flow & - & 40 \\
\hline $7 R-3$ & 92 & 36.53 & Pillow lava & 90 & - \\
\hline $7 R-4$ & 93 & 36.78 & Pillow lava & - & 10 \\
\hline $8 \mathrm{R}-1$ & 96 & 38.31 & Peperite & 10 & - \\
\hline 9R-1 & 98 & 42.27 & Peperitic lava flow & - & 50 \\
\hline $9 \mathrm{R}-2$ & 99 & 43.73 & Peperitic lava flow & - & 10 \\
\hline $9 \mathrm{R}-2$ & 100 & 44.07 & Peperitic lava flow & 40 & - \\
\hline 9R-2 & 101 & 44.44 & Peperitic lava flow & - & 20 \\
\hline 13R-1 & 105 & 50.83 & Lava flow with peperite top & 20 & 95 \\
\hline
\end{tabular}

$-=$ no data.

Table T7. Lavas with flow alignment textures, Hole U1373A.

\begin{tabular}{lll}
\hline $\begin{array}{c}\text { Core, section, } \\
\text { interval }(\mathrm{cm})\end{array}$ & $\begin{array}{l}\text { Depth } \\
\text { (mbsf) }\end{array}$ & \multicolumn{1}{c}{ Description } \\
\hline $\begin{array}{c}\text { 330-U1373A- } \\
\text { 6R-1, 17-25 }\end{array}$ & 28.0 & $\begin{array}{l}\text { Basaltic flow with moderate-strong flow alignment } \\
\text { 9R-2, 38-52 }\end{array}$ \\
Basaltic flow with moderate flow alignment \\
10R-1, 0-124 & 47.0 & Basaltic flow with moderate-strong flow alignment \\
10R-2, 0-143 & 48.0 & Basaltic flow with moderate-strong flow alignment \\
10R-3, 0-138 & 50.0 & Basaltic flow with weak-moderate flow alignment \\
11R-1, 9-131 & 52.4 & Basaltic flow with moderate flow alignment \\
11R-2, 0-134 & 53.5 & Basaltic flow with weak-moderate flow alignment \\
11R-3, 1-64 & 54.0 & Basaltic flow with moderate-strong flow alignment \\
12R-1, 33-40 & 56.4 & Basaltic flow with strong flow alignment \\
13R-1, 9-73 & 61.0 & Basaltic flow with moderate flow alignment \\
13R-2, 0-96 & 62.5 & Basaltic flow with strong flow alignment \\
13R-3, 0-130 & 64.0 & Strong flow alignment \\
\hline
\end{tabular}


Table T8. Whole-rock major and trace element compositions, Hole U1373A.

\begin{tabular}{|c|c|c|c|c|c|c|c|c|c|c|}
\hline \multirow{2}{*}{$\begin{array}{r}\text { Hole: } \\
\text { Core, section: }\end{array}$} & \multicolumn{10}{|c|}{ 330-U1373A- } \\
\hline & 1R-1 & 1R-2 & $2 \mathrm{R}-3$ & $7 R-2$ & $7 R-3$ & $8 \mathrm{R}-2$ & 9R-2 & $9 \mathrm{R}-3$ & $10 \mathrm{R}-4$ & $13 R-3$ \\
\hline Piece: & 4B & 2 & $4 B$ & $7 B$ & $6 \mathrm{~B}$ & $10 \mathrm{~A}$ & $5 B$ & 1B & 3 & 2 \\
\hline Interval $(\mathrm{cm})$ : & $43-45$ & $121-123$ & $135-137$ & $125-127$ & $106-108$ & $115-117$ & $115-118$ & $41-43$ & $30-32$ & $10-12$ \\
\hline Top depth (mbsf): & 0.43 & 2.01 & 13.62 & 35.19 & 36.49 & 39.97 & 44.46 & 45.17 & 50.85 & 63.68 \\
\hline Strat. unit: & 1 & 1 & ॥ & IV & IV & $\mathrm{VI}$ & VII & VII & VII & VII \\
\hline \multicolumn{11}{|c|}{ Major element oxide (wt\%): } \\
\hline $\mathrm{SiO}_{2}$ & 47.05 & 46.28 & 45.64 & 45.24 & 46.12 & 48.53 & 44.37 & 49.65 & 47.23 & 49.76 \\
\hline $\mathrm{TiO}_{2}$ & 3.35 & 2.17 & 3.41 & 2.39 & 2.73 & 3.16 & 3.18 & 3.13 & 3.10 & 3.21 \\
\hline $\mathrm{Al}_{2} \mathrm{O}_{3}$ & 14.56 & 12.84 & 14.71 & 12.67 & 13.53 & 15.41 & 15.34 & 15.14 & 15.10 & 15.29 \\
\hline $\mathrm{Fe}_{2} \mathrm{O}_{3}^{\top}$ & 13.50 & 11.92 & 14.64 & 12.89 & 12.91 & 13.45 & 13.32 & 11.68 & 13.16 & 13.33 \\
\hline $\mathrm{MnO}$ & 0.15 & 0.16 & 0.17 & 0.16 & 0.18 & 0.17 & 0.20 & 0.17 & 0.16 & 0.16 \\
\hline $\mathrm{MgO}$ & 6.63 & 13.62 & 5.14 & 13.27 & 10.73 & 5.17 & 4.76 & 5.42 & 6.17 & 5.97 \\
\hline $\mathrm{CaO}$ & 10.71 & 11.58 & 11.45 & 11.98 & 12.12 & 11.71 & 11.02 & 12.23 & 11.69 & 11.81 \\
\hline $\mathrm{Na}_{2} \mathrm{O}$ & 2.75 & 1.91 & 2.70 & 2.26 & 2.59 & 3.18 & 3.32 & 3.27 & 3.21 & 3.16 \\
\hline $\mathrm{K}_{2} \mathrm{O}$ & 1.00 & 0.45 & 2.70 & 0.70 & 0.84 & 1.19 & 1.33 & 0.97 & 0.79 & 0.74 \\
\hline $\mathrm{P}_{2} \mathrm{O}_{5}$ & 0.49 & 0.25 & 0.55 & 0.40 & 0.47 & 0.48 & 0.52 & 0.46 & 0.47 & 0.48 \\
\hline Totals: & 100.19 & $\begin{array}{l}01.18 \\
\end{array}$ & 101.11 & 101.95 & 102.21 & 102.44 & 97.35 & 102.12 & 101.08 & 103.92 \\
\hline LOI & 2.4 & 1.1 & 7.2 & 2.3 & 1.9 & 2.2 & 2.0 & 2.3 & 1.5 & 0.9 \\
\hline \multicolumn{11}{|c|}{ Major element oxide (wt\%) normalized to $100 \mathrm{wt} \%$ : } \\
\hline $\mathrm{SiO}_{2}$ & 46.97 & 45.74 & 45.14 & 44.38 & 45.12 & 47.37 & 45.58 & 48.62 & 46.73 & 47.89 \\
\hline $\mathrm{TiO}_{2}$ & 3.34 & 2.14 & 3.38 & 2.34 & 2.67 & 3.08 & 3.26 & 3.06 & 3.07 & 3.09 \\
\hline $\mathrm{Al}_{2} \mathrm{O}_{3}$ & 14.53 & 12.69 & 14.55 & 12.43 & 13.23 & 15.05 & 15.76 & 14.83 & 14.93 & 14.72 \\
\hline $\mathrm{Fe}_{2} \mathrm{O}_{3}^{\top}$ & 13.48 & 11.78 & 14.48 & 12.64 & 12.63 & 13.13 & 13.69 & 11.44 & 13.02 & 12.83 \\
\hline $\mathrm{MnO}$ & 0.15 & 0.16 & 0.17 & 0.16 & 0.17 & 0.16 & 0.20 & 0.16 & 0.16 & 0.15 \\
\hline $\mathrm{MgO}$ & 6.62 & 13.46 & 5.08 & 13.02 & 10.50 & 5.05 & 4.89 & 5.31 & 6.10 & 5.75 \\
\hline $\mathrm{CaO}$ & 10.69 & 11.45 & 11.32 & 11.75 & 11.86 & 11.43 & 11.32 & 11.98 & 11.56 & 11.36 \\
\hline $\mathrm{Na}_{2} \mathrm{O}$ & 2.75 & 1.89 & 2.67 & 2.21 & 2.54 & 3.10 & 3.42 & 3.20 & 3.17 & 3.05 \\
\hline $\mathrm{K}_{2} \mathrm{O}$ & 1.00 & 0.44 & 2.67 & 0.68 & 0.82 & 1.16 & 1.36 & 0.95 & 0.78 & 0.71 \\
\hline $\mathrm{P}_{2} \mathrm{O}_{5}$ & 0.49 & 0.24 & 0.54 & 0.39 & 0.46 & 0.47 & 0.53 & 0.45 & 0.46 & 0.46 \\
\hline Totals: & 100.00 & 100.00 & 100.00 & 100.00 & 100.00 & 100.00 & 100.00 & 100.00 & 100.00 & 100.00 \\
\hline Mg\# & 53.3 & 72.7 & 45.0 & 70.6 & 65.9 & 47.2 & 45.4 & 51.9 & 52.2 & 51.0 \\
\hline \multicolumn{11}{|l|}{ Trace element (ppm): } \\
\hline $\mathrm{Ba}$ & 207 & 95 & 232 & 176 & 221 & 168 & 179 & 163 & 162 & 172 \\
\hline $\mathrm{Sr}$ & 607 & 382 & 417 & 610 & 726 & 511 & 522 & 536 & 527 & 553 \\
\hline $\mathrm{Zr}$ & 258 & 138 & 258 & 171 & 200 & 234 & 210 & 232 & 211 & 235 \\
\hline $\mathrm{Y}$ & 31 & 20 & 27 & 21 & 23 & 31 & 31 & 31 & 30 & 31 \\
\hline $\mathrm{V}$ & 339 & 275 & 285 & 255 & 263 & 342 & 354 & 344 & 339 & 342 \\
\hline Sc & 23 & 33 & 22 & 29 & 25 & 30 & 31 & 30 & 30 & 30 \\
\hline $\mathrm{Cu}$ & 58 & 90 & 95 & 106 & 107 & 105 & 132 & 125 & 111 & 125 \\
\hline $\mathrm{Zn}$ & 120 & 90 & 119 & 92 & 96 & 108 & 174 & 112 & 105 & 109 \\
\hline Co & 64 & 70 & 69 & 70 & 68 & 62 & 64 & 58 & 60 & 66 \\
\hline $\mathrm{Cr}$ & 9 & 794 & 270 & 729 & 466 & 68 & 55 & 53 & 63 & 52 \\
\hline $\mathrm{Ni}$ & 39 & 341 & 161 & 381 & 277 & 65 & 70 & 72 & 70 & 69 \\
\hline
\end{tabular}

All analyses were conducted on samples ignited to $960^{\circ} \mathrm{C}$. $\mathrm{Fe}_{2} \mathrm{O}_{3}{ }^{\top}=$ total iron expressed as $\mathrm{Fe}_{2} \mathrm{O}_{3}$. LOI $=$ weight loss on ignition. $\mathrm{Mg} \#=100 \times$ $\mathrm{Mg}^{2+} /\left(\mathrm{Mg}^{2+}+\mathrm{Fe}^{2+}\right)$, assuming that $\mathrm{Fe}_{2} \mathrm{O}_{3} / \mathrm{FeO}=0.15$. 
Table T9. Moisture and density measurements, Site U1373.

\begin{tabular}{|c|c|c|c|c|c|c|c|}
\hline \multirow{2}{*}{$\begin{array}{l}\text { Core, section, } \\
\text { interval }(\mathrm{cm})\end{array}$} & \multirow{2}{*}{$\begin{array}{l}\text { Top depth } \\
\text { (mbsf) }\end{array}$} & \multicolumn{3}{|c|}{ Density $\left(\mathrm{g} / \mathrm{cm}^{3}\right)$} & \multirow[b]{2}{*}{ Void ratio } & \multirow{2}{*}{$\begin{array}{l}\text { Water content } \\
\text { (\%) }\end{array}$} & \multirow{2}{*}{$\begin{array}{c}\text { Porosity } \\
\text { (\%) }\end{array}$} \\
\hline & & Bulk & Dry & Grain & & & \\
\hline \multicolumn{8}{|l|}{ 330-U1373A- } \\
\hline 1R-1, 37-39 & 0.37 & 2.681 & 2.585 & 2.851 & 0.103 & 3.56 & 9.32 \\
\hline $1 \mathrm{R}-2,15-17$ & 0.95 & 2.395 & 2.103 & 2.942 & 0.399 & 12.20 & 28.53 \\
\hline $1 \mathrm{R}-2,94-96$ & 1.74 & 3.105 & 3.093 & 3.129 & 0.011 & 0.37 & 1.13 \\
\hline $2 \mathrm{R}-1,76-78$ & 10.36 & 2.558 & 2.353 & 2.943 & 0.251 & 8.03 & 20.07 \\
\hline $2 \mathrm{R}-2,78-80$ & 11.71 & 2.425 & 2.166 & 2.898 & 0.338 & 10.67 & 25.26 \\
\hline $2 \mathrm{R}-4,13-15$ & 13.85 & 2.418 & 2.224 & 2.745 & 0.235 & 8.05 & 19.01 \\
\hline $3 R-1,52-54$ & 14.62 & 2.234 & 1.856 & 2.943 & 0.586 & 16.93 & 36.94 \\
\hline $3 R-2,87-89$ & 15.93 & 2.534 & 2.356 & 2.851 & 0.210 & 7.01 & 17.36 \\
\hline $3 R-3,129-131$ & 17.24 & 2.450 & 2.208 & 2.891 & 0.309 & 9.88 & 23.62 \\
\hline $4 \mathrm{R}-1,43-45$ & 19.03 & 2.396 & 2.145 & 2.844 & 0.326 & 10.50 & 24.57 \\
\hline $5 R-2,38-40$ & 25.67 & 2.721 & 2.619 & 2.910 & 0.111 & 3.77 & 10.01 \\
\hline $6 \mathrm{R}-2,11-15$ & 29.28 & 2.339 & 2.012 & 2.954 & 0.468 & 13.96 & 31.88 \\
\hline $7 \mathrm{R}-1,68-70$ & 33.38 & 2.875 & 2.777 & 3.071 & 0.106 & 3.40 & 9.56 \\
\hline $7 \mathrm{R}-2,18-20$ & 34.12 & 2.988 & 2.971 & 3.020 & 0.017 & 0.56 & 1.64 \\
\hline $7 \mathrm{R}-3,5-7$ & 35.48 & 2.918 & 2.870 & 3.010 & 0.049 & 1.63 & 4.65 \\
\hline 7R-3, 101-103 & 36.44 & 2.606 & 2.484 & 2.821 & 0.136 & 4.70 & 11.95 \\
\hline 7R-4, 11-13 & 36.77 & 2.561 & 2.337 & 2.990 & 0.279 & 8.73 & 21.84 \\
\hline $7 R-4,62-64$ & 37.28 & 2.465 & 2.220 & 2.917 & 0.314 & 9.93 & 23.89 \\
\hline $8 \mathrm{R}-1,21-23$ & 37.61 & 2.234 & 1.924 & 2.760 & 0.434 & 13.88 & 30.29 \\
\hline 7R-4, 108-110 & 37.74 & 2.303 & 1.985 & 2.879 & 0.450 & 13.81 & 31.05 \\
\hline $7 R-5,20-22$ & 38.28 & 2.367 & 2.103 & 2.832 & 0.347 & 11.14 & 25.75 \\
\hline $8 R-2,67-69$ & 39.49 & 2.286 & 2.087 & 2.589 & 0.241 & 8.69 & 19.39 \\
\hline $8 R-4,100-102$ & 42.23 & 2.333 & 2.078 & 2.770 & 0.333 & 10.97 & 24.99 \\
\hline $9 \mathrm{R}-2,86-88$ & 44.17 & 2.444 & 2.258 & 2.760 & 0.222 & 7.62 & 18.20 \\
\hline 9R-2, 104-106 & 44.35 & 2.457 & 2.251 & 2.819 & 0.253 & 8.40 & 20.16 \\
\hline $9 \mathrm{R}-3,30-32$ & 45.06 & 2.727 & 2.663 & 2.843 & 0.068 & 2.38 & 6.33 \\
\hline 10R-1, 67-69 & 47.17 & 2.950 & 2.925 & 2.998 & 0.025 & 0.84 & 2.41 \\
\hline 10R-4, 68-70 & 51.23 & 2.861 & 2.826 & 2.925 & 0.035 & 1.22 & 3.40 \\
\hline $11 \mathrm{R}-2,82-84$ & 53.44 & 2.861 & 2.827 & 2.924 & 0.034 & 1.19 & 3.32 \\
\hline $11 \mathrm{R}-2,129-131$ & 53.91 & 2.846 & 2.806 & 2.920 & 0.041 & 1.40 & 3.89 \\
\hline $11 \mathrm{R}-3,72-74$ & 54.69 & 2.774 & 2.719 & 2.873 & 0.057 & 1.98 & 5.38 \\
\hline $12 \mathrm{R}-2,59-61$ & 57.94 & 2.667 & 2.509 & 2.967 & 0.182 & 5.92 & 15.43 \\
\hline $13 R-4,78-80$ & 65.78 & 2.882 & 2.848 & 2.947 & 0.035 & 1.20 & 3.37 \\
\hline
\end{tabular}

Water content is relative to wet mass. 
Table T10. Compressional wave velocity measurements, Site U1373.

\begin{tabular}{|c|c|c|c|c|c|}
\hline \multirow{2}{*}{$\begin{array}{l}\text { Core, section, } \\
\text { interval }(\mathrm{cm})\end{array}$} & \multirow{2}{*}{$\begin{array}{l}\text { Top depth } \\
\text { (mbsf) }\end{array}$} & \multicolumn{4}{|c|}{ Velocity $(\mathrm{km} / \mathrm{s})$} \\
\hline & & $x$ & $y$ & $z$ & Average \\
\hline \multicolumn{6}{|l|}{ 330-U1373A- } \\
\hline 1R-1, 37-39 & 0.37 & 5.429 & 5.349 & 5.451 & 5.410 \\
\hline $1 \mathrm{R}-2,15-17$ & 0.95 & 3.427 & 3.377 & 3.392 & 3.399 \\
\hline $1 \mathrm{R}-2,94-96$ & 1.74 & 6.963 & 6.938 & 7.037 & 6.979 \\
\hline 2R-1, 76-78 & 10.36 & 3.856 & 3.696 & 3.920 & 3.824 \\
\hline $2 \mathrm{R}-2,78-80$ & 11.71 & 3.520 & 3.474 & 3.536 & 3.510 \\
\hline $2 \mathrm{R}-4,13-15$ & 13.85 & 4.824 & 4.875 & 4.863 & 4.854 \\
\hline $3 R-1,52-54$ & 14.62 & 3.129 & 3.151 & 3.279 & 3.187 \\
\hline $3 R-2,87-89$ & 15.93 & 4.659 & 4.650 & 4.628 & 4.646 \\
\hline 3R-3, 129-131 & 17.24 & 4.038 & 4.033 & 3.989 & 4.020 \\
\hline $4 \mathrm{R}-1,43-45$ & 19.03 & 3.584 & 3.585 & 3.527 & 3.565 \\
\hline $5 \mathrm{R}-2,38-40$ & 25.67 & 5.472 & 5.526 & 5.612 & 5.537 \\
\hline $6 \mathrm{R}-2,11-15$ & 29.28 & ND & ND & 3.241 & 3.241 \\
\hline $7 \mathrm{R}-1,68-70$ & 33.38 & 4.788 & 4.504 & 4.725 & 4.672 \\
\hline $7 R-2,18-20$ & 34.12 & 7.018 & 7.081 & 7.051 & 7.050 \\
\hline $7 \mathrm{R}-3,5-7$ & 35.48 & 6.202 & 6.357 & 6.271 & 6.276 \\
\hline 7R-3, 101-103 & 36.44 & 5.322 & 5.314 & 5.320 & 5.319 \\
\hline $7 \mathrm{R}-4,11-13$ & 36.77 & 4.244 & 4.139 & 4.178 & 4.187 \\
\hline $7 R-4,62-64$ & 37.28 & 4.228 & 4.161 & 4.204 & 4.198 \\
\hline $8 R-1,21-23$ & 37.61 & 4.020 & 3.838 & 3.717 & 3.858 \\
\hline 7R-4, 108-110 & 37.74 & 3.125 & 3.234 & 3.061 & 3.140 \\
\hline $7 R-5,20-22$ & 38.28 & 3.612 & 3.489 & 3.358 & 3.486 \\
\hline $8 R-2,67-69$ & 39.49 & 4.467 & 4.524 & 4.482 & 4.491 \\
\hline $8 R-4,100-102$ & 42.23 & 3.891 & 3.885 & 3.903 & 3.893 \\
\hline $9 \mathrm{R}-2,86-88$ & 44.17 & 4.744 & 4.533 & 4.644 & 4.640 \\
\hline 9R-2, 104-106 & 44.35 & 4.523 & 4.126 & 4.558 & 4.402 \\
\hline $9 \mathrm{R}-3,30-32$ & 45.06 & 6.129 & 6.111 & 6.115 & 6.119 \\
\hline $10 \mathrm{R}-4,68-70$ & 51.23 & 6.396 & 6.546 & 6.660 & 6.534 \\
\hline $11 \mathrm{R}-2,82-84$ & 53.44 & 6.344 & 6.422 & 6.443 & 6.403 \\
\hline $11 \mathrm{R}-2,129-131$ & 53.91 & 6.478 & 6.419 & 6.424 & 6.440 \\
\hline $11 \mathrm{R}-3,72-74$ & 54.685 & 6.246 & 6.192 & 6.141 & 6.193 \\
\hline $12 \mathrm{R}-2,59-61$ & 57.94 & 4.946 & 4.859 & 4.707 & 4.837 \\
\hline $13 R-4,78-80$ & 65.78 & 6.626 & 6.690 & 6.599 & 6.639 \\
\hline
\end{tabular}

Values are accurate to $\pm 20 \mathrm{~m} / \mathrm{s}$. Discrete Sample 330-U1373A-8R-1, 21-23 cm, is listed at a depth apparently within Section 7R-4 because of the use of IODP depth scale CSF-A, which allows for core overlap when recovery is $>100 \%$. ND = no data (shape of discrete Sample 330-U1373A-6R$2,11-15 \mathrm{~cm}$, did not allow $P$-wave velocity measurements for the $x$ - and $y$-axes).

Table T11. Thermal conductivity measurements, Site U1373.

\begin{tabular}{|c|c|c|c|c|c|}
\hline $\begin{array}{l}\text { Core, section, } \\
\text { interval }(\mathrm{cm})\end{array}$ & $\begin{array}{l}\text { Top depth } \\
\text { (mbsf) }\end{array}$ & $\begin{array}{l}\text { Thermal } \\
\text { conductivity } \\
(\mathrm{W} /[\mathrm{m} \cdot \mathrm{K}])\end{array}$ & $\begin{array}{c}\text { Standard } \\
\text { deviation } \\
(\mathrm{W} /[\mathrm{m} \cdot \mathrm{K}])\end{array}$ & Space & Material \\
\hline \multicolumn{6}{|l|}{ 330-U1373A- } \\
\hline 1R-2, 138 & 2.18 & 2.290 & 0.053 & Half & Conglomerate \\
\hline $2 \mathrm{R}-2,102$ & 11.95 & 1.407 & 0.013 & Half & Basalt \\
\hline $3 R-3,134$ & 17.29 & 1.550 & 0.104 & Half & Conglomerate \\
\hline $5 \mathrm{R}-2,88$ & 26.17 & 1.803 & 0.004 & Half & Conglomerate \\
\hline 6R-2, 91 & 30.08 & 1.334 & 0.018 & Half & Conglomerate \\
\hline $7 R-4,128$ & 37.94 & 1.211 & 0.015 & Half & Basalt \\
\hline $8 \mathrm{R}-2,93$ & 39.75 & 1.493 & 0.008 & Half & Basalt \\
\hline $9 \mathrm{R}-1,99$ & 43.09 & 1.201 & 0.024 & Half & Basalt \\
\hline 10R-3, 14 & 49.31 & 1.179 & 0.040 & Half & Basalt \\
\hline 11R-3, 103 & 55.00 & 1.781 & 0.017 & Half & Basalt \\
\hline $12 \mathrm{R}-2,71$ & 58.06 & 1.489 & 0.007 & Half & Basalt \\
\hline $13 \mathrm{R}-3,58$ & 64.16 & 1.746 & 0.010 & Half & Basalt \\
\hline
\end{tabular}


Table T12. Magnetic properties and demagnetization results for discrete samples, Hole U1373A. This table is available in an oversized format.

Table T13. Anisotropy of magnetic susceptibility results for discrete samples, Hole U1373A. This table is available in an oversized format.

Table T14. Inclination-only averages for lithologic units, Hole U1373A.

\begin{tabular}{|c|c|c|c|c|c|c|c|c|c|c|c|c|c|c|c|}
\hline \multirow[b]{3}{*}{$\begin{array}{l}\text { Strat. } \\
\text { unit }\end{array}$} & \multirow[b]{3}{*}{$\begin{array}{l}\text { Lith. } \\
\text { unit }\end{array}$} & \multirow[b]{3}{*}{$\mathrm{ISCl}$} & \multirow[b]{3}{*}{ Lithology } & \multirow{3}{*}{\multicolumn{2}{|c|}{ Lith. unit depth (mbsf) }} & \multicolumn{5}{|c|}{ Averages from $2 \mathrm{~cm}$ archive-half core data } & \multicolumn{5}{|c|}{ Averages from Fisher piece averages } \\
\hline & & & & & & \multirow[b]{2}{*}{$n$} & \multicolumn{2}{|c|}{ Inclination $\left(^{\circ}\right)$} & \multirow[b]{2}{*}{$\alpha_{63}$} & \multirow[b]{2}{*}{$\alpha_{95}$} & \multirow[b]{2}{*}{$n$} & \multicolumn{2}{|c|}{ Inclination $\left(^{\circ}\right)$} & \multirow[b]{2}{*}{$\alpha_{63}$} & \multirow[b]{2}{*}{$\alpha_{95}$} \\
\hline & & & & & $\frac{\text { th (mbsf) }}{\text { Bottom }}$ & & $\begin{array}{l}\text { Arithmetic } \\
\text { mean }\end{array}$ & $\begin{array}{l}\text { Maximum } \\
\text { likelihood }\end{array}$ & & & & $\begin{array}{l}\text { Arithmetic } \\
\text { mean }\end{array}$ & $\begin{array}{l}\text { Maximum } \\
\text { likelihood }\end{array}$ & & \\
\hline IA & - & NA & Sediment & 0.00 & 0.15 & & & & & & & & & & \\
\hline IB & - & NA & Sediment & 0.15 & 2.66 & $41^{\dagger}$ & & & & & 1 & -46.2 & & & \\
\hline IC & - & NA & Sediments & 2.66 & 3.05 & 6 & 13.5 & 14.2 & 25.4 & 21.9 & 1 & 29.4 & & & \\
\hline II & 1 & NA & Volcanic breccia & 9.60 & 10.98 & 43 & 26.6 & 29.7 & 32.7 & 9.5 & & & & & \\
\hline ॥ & 2 & NA & Volcanic breccia & 10.98 & 11.42 & 12 & -17.4 & -18.0 & 16.8 & 9.2 & & & & & \\
\hline II & 3 & NA & Volcanic breccia & 11.42 & 14.17 & 64 & 7.0 & 7.3 & 21.9 & 5.0 & 2 & 20.4 & 20.7 & 13.3 & 42.1 \\
\hline ॥ & 4 & NA & Volcanic breccia & 14.17 & 15.27 & 21 & -6.2 & -22.7 & 78.3 & 154.2 & 1 & -12.3 & & & \\
\hline ॥ & 5 & NA & Volcanic breccia & 15.27 & 15.70 & 11 & -20.7 & -24.1 & 37.7 & 23.4 & & & & & \\
\hline IIIA & - & NA & Sediment & 15.70 & 17.07 & 23 & 11.4 & 12.5 & 33.9 & 13.7 & & & & & \\
\hline IIIB & - & NA & Sediment & 17.07 & 19.84 & 10 & 15.9 & 17.9 & 34.7 & 22.5 & 3 & 15.4 & 17.9 & 36.6 & 61.8 \\
\hline IIIC & - & NA & Sediment & 23.80 & 29.17 & 6 & -15.0 & -16.2 & 26.5 & 23.0 & 3 & -15.3 & -16.5 & 26.5 & 42.6 \\
\hline IIID & - & NA & Sediment & 29.17 & 33.90 & 6 & -58.6 & -60.7 & 15.7 & 13.2 & 3 & -57.7 & -64.2 & 24.6 & 39.2 \\
\hline IV & 6 & 3 & Massive lava flow & 33.91 & 36.39 & 49 & -65.1 & -65.7 & 7.5 & 1.9 & 5 & -64.5 & -64.7 & 5.3 & 5.0 \\
\hline IV & 7 & 3 & Pillow lava & 36.39 & 36.66 & 2 & -55.4 & -63.2 & 27.5 & 98.5 & & & & & \\
\hline V & 8 & 3 & Pillow lava & 36.66 & 36.90 & 7 & -55.7 & -55.7 & 1.8 & 1.4 & 1 & -55.7 & & & \\
\hline V & 9 & 3 & Lava flow & 36.90 & 37.53 & 20 & -57.9 & -58.1 & 5.4 & 2.2 & 2 & -56.7 & -56.7 & 2.0 & 6.1 \\
\hline V & 10 & 3 & Peperite & 37.53 & 38.14 & 11 & -45.5 & -46.0 & 10.8 & 6.1 & 3 & -44.8 & -45.3 & 10.3 & 15.9 \\
\hline $\mathrm{VI}$ & 11 & 3 & Peperite & 38.14 & 39.05 & 47 & -44.6 & -45.7 & 15.6 & 4.1 & 5 & -44.3 & -44.5 & 7.2 & 6.8 \\
\hline VI & 12 & 3 & Lava flow with peperite top and base & 39.05 & 41.02 & 33 & -39.4 & -40.0 & 12.5 & 3.9 & 6 & -35.1 & -35.6 & 12.0 & 10.1 \\
\hline $\mathrm{VI}$ & 13 & 3 & Peperitic lava flow & 41.02 & 43.31 & 62 & -40.3 & -40.4 & 6.4 & 1.4 & 3 & -40.0 & -40.0 & 2.4 & 3.7 \\
\hline VII & 14 & 3 & Peperitic lava flow & 43.31 & 43.98 & 8 & -33.4 & -33.8 & 11.9 & 8.2 & 2 & -31.5 & -31.8 & 10.6 & 33.4 \\
\hline VII & 15 & 3 & Lava flow with peperite top & 43.98 & 66.17 & $89(94)^{*}$ & -55.5 & -59.5 & 21.8 & 4.2 & $21(24)^{*}$ & -53.4 & -55.0 & 12.8 & 6.3 \\
\hline
\end{tabular}

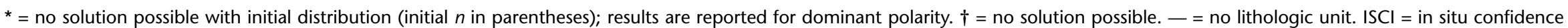

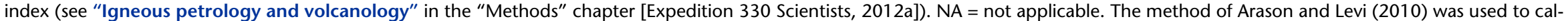
culate inclination-only mean and associated statistics. $\alpha_{63}=$ circular standard deviation, $\alpha_{95}=95 \%$ confidence angle. 